


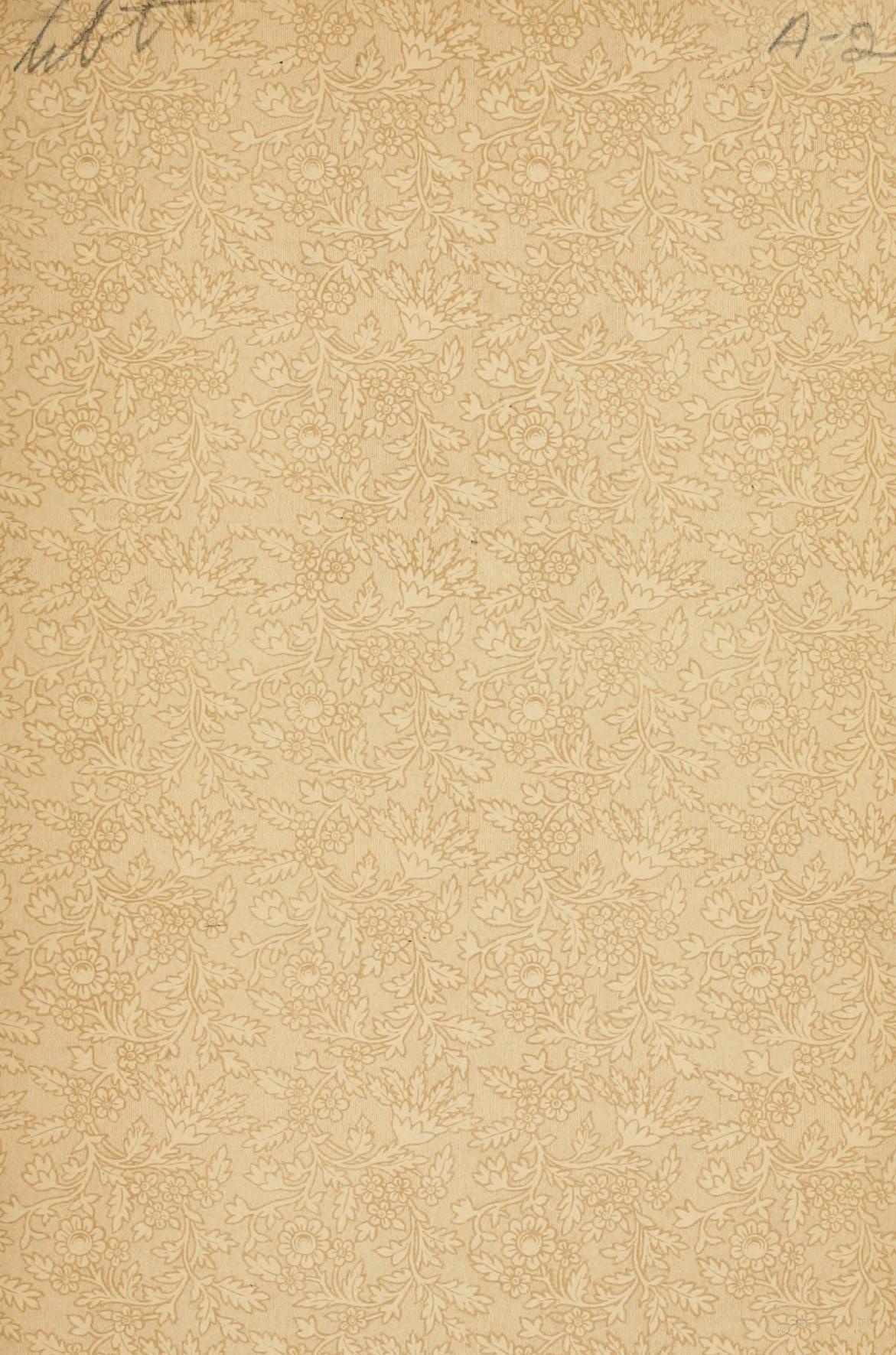



$B-1$ 


UNIFORM WITH THIS VOLUME.

New England Bird Life:

BEING

A MANUAL OF NEW ENGLAND

ORNITHOLOGY.

Revised and edited from the manuscript of Winfrid A. Stearns, ........ Member of the Nuttall Ornithological Club, etc.

$\because$ By Dr. ELLIOTT COUES, U.S.A., Member of the Academy, etc.

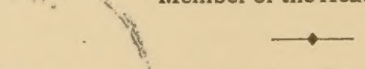

Part 1. Osdines (Singing Birds). Illustrated, \$2.50.

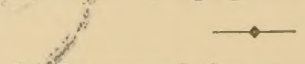

See Recommendations at end of this volume.

LEE AND SHEPARD, PUBlishers, Boston. 


\section{NEW ENGLAND BIRD LIFE}

pt. 2

BEING A

Birds

\section{A N U A L}

OF

\section{NEW ENGLAND ORNITHOLOGY}

REVISED AND EDITED FROM THE MANUSCRIPT OF

WINFRID A. STEARNS

Member of the NUTtall oRnithological Club etC.

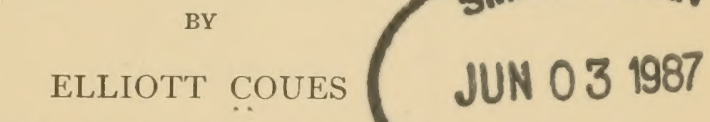
MEMBER OF THE ACADEMY ETC.

WBRARIES
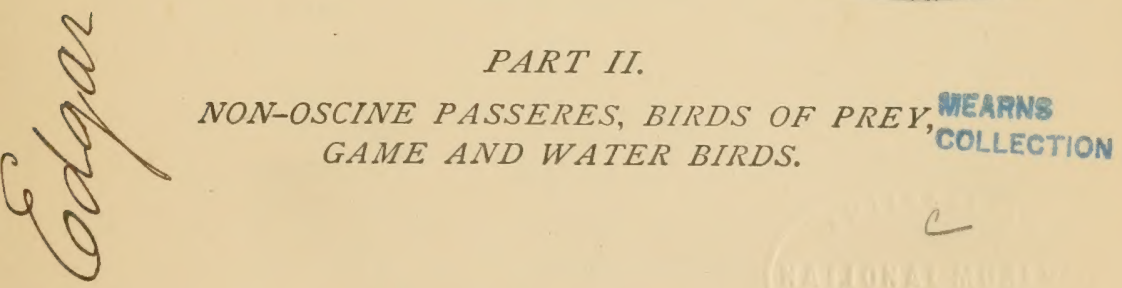

BOSTON

LEE AND SHEPARD PUBLISHERS NEW YORK CHARLES T. DILLINGHAM I 883 


\title{
PUBLISHERS' NOTE.
}

As circumstances within the control of the editor have enabled him to complete the revision of the work, that portion embracing the Non-oscine Passeres and other remaining Land Birds, together with all the Water Birds, is now issued as Part II., concluding the treatise.

\author{
COPYRIGHT, 1883. \\ By LEE AND SHEPARD. \\ All Rights Reserved.
}

BOSTON STEREOTYPE FOUNDRY, No. 4 Pearl Street.

Presswork by John Wilson \& Son, Cambridge. 


\section{CONTENTS.}

PAGE

EDITOR'S PREFACE . . . . . . . . . 5

BIRDS OF NEW ENGLAND . . . . . . . II

Family Tyrannida: Flycatchers . . . II

Caprimulgide: Whippoorwills and Night-hawks, 50

Cypselida :

Trochilida:

Swifts . . . . 56

Alcedinida: Kingfishers . . . 62

Cuculida: Cuckoos . . . . . 65

Picide: Woodpeckers . . . 69

Strigide: Owls . . . . 86

Falconida: Hawks . . . . . 101

Cathartide: American Vultures . . . I35

Columbida: Pigeons . . . . I39

Meleagridida: Turkeys . . . . . I45

Tetraonida: Grouse, Partridge . • . I45

Charadriida: Plovers . . . . I63

Hamatopodide: Oyster-catchers . . • . I77

Recurvirostrida: Avocets, Stilts . . . . I80

Phalaropodida: Phalaropes . . . 184

Scolopacida: Snipe, \&c. ․ . . I9I 
CONTENTS.

PAGE

Family Ibidida :

Ibises . . . . 254

Ardeide: Herons . . . . 259

Gruidc: Cranes . . . . . 276

Rallide: $\quad$ Rails and their Allies . . 279

Anatide: $\quad$ Swans, Geese, and Ducks . 296

Sulide: Gannets . . . . 334

Pelecanida: Pelicans . . . . 337

Phalacrocoracida: Cormorants . . . . 339

Tachypetide: Frigates . . . . 34I

Larida : Jaegers, Gulls, Terns, Skimmers, 343

Procellariida: Petrels . . . . 330

Colymbida: Loons . . . . 388

Fodicipedide: Grebes . . . . 39I

Alcide: Auks . . . . 394 


\section{EDITOR'S PREFACE.}

Apology is due that portion of the public which may be interested in "New England Bird Life" for the delay which has occurred in the preparation and publication of the concluding volume of this treatise.

In November, I880, when, the revision of Mr. Stearns' manuscript having been made through Oscines, the first volume had gone to press, the editor was directed by the War Department to repair to Arizona and take up the routine duties of a medical officer of the army; and it was several months before he could free himself from this annoyance by resigning his commission. It being clearly impracticable to do any literary or scientific work under such circumstances, preparation of the manuscript for the press was necessarily suspended at the point it had then reached. Proofs of the portion already in the printer's hands having been read by the editor in Arizona, Part I., embracing Oscines, was published upon his return to Washington in September, I88I. 
To the same outrage is mainly to be ascribed that imperfection of the present volume, of which no one can be more fully aware than the editor. Resuming his avocations with nearly a year's arrested work of various kinds upon his hands, it was found impossible to give the present treatise all the attention he would otherwise have been able to bestow upon it. He was also cramped for room to adequately treat the many remaining Birds of New England in one volume which should approximately equal the first in enforced number of pages. He may therefore with propriety deprecate criticism of Part II., in so far as his responsibility for it is concerned; and refer, in evidence of the embarrassment to which he alludes, to some of the matters which divided his attention during the period of which he speaks.

The "Coues Check List," etc., which was sent to press in September, I880, revision for its second edition having been completed in July of the same year, was practically suspended until his return, and further delayed in publication until June, I882. The second edition of the "Key," etc., long contemplated both by publisher and author, could not be put to press until some months after his return, entire rewriting of the work, with addition of much new matter, being required to bring it up to date. Each of these works being in press while the present treatise was in the same state, all of them far behindhand, the three together made unusually urgent demands upon time and patience ; and 
in the case of the "Key" the unavoidable delay has not yet been overcome. The "Bibliography of Ornithology," the third instalment of which protracted labor happily appeared in November, 1880 , and the "Birds of the Colorado Valley," Part II., having both been suspended during publication by the same ill-timed interruption, need not be considered in the present connection. But a more serious difficulty, because one involving an official obligation, occurred in the case of the "History of North American Quadrupeds," ordered by Congress in I 880 to be prepared and published as Vol. XIV. of the Reports of the U. S. Geological and Geographical Survey of the Territories, the elaboration of the text and the superintendence of the drawing and engraving of the necessary illustrations having continuously required his attention, before, during and after the long indignity to which he was subjected.

The editor takes great pleasure in recognizing the timely and valued assistance rendered in the preparation of this work by his friend, Mr. H. A. Purdie, of Boston. As in the case of Part I., Mr. Purdie has very kindly gone over the scattered published records of the species to be treated, furnishing extended memoranda, which have proved an invaluable saving of time and labor; for which, as well as for important suggestions and criticisms made by the same well-known ornithologist in reading the proof-sheets, both author and editor are greatly indebted. 
In no other part of the United States have the Birds of our country been so closely and successfully studied as in New England, where a host of zealous and watchful field-naturalists, stimulated and to a great extent led by the Nuttall Ornithological Club, have brought our knowledge of bird-life in all its details near that degree of perfection which is witnessed in the writings of British authors upon the Birds of their own islands. The material for an exhaustive treatise upon New England Ornithology - if it be desired to have a complete special History of New England Birds apart from those of North America at large - is ample and inviting. Much of it, hitherto widely scattered and in the raw, has been brought together and to a degree systematized in the present treatise, numberless sources of information having been utilized as well as the untoward circumstances permitted; but, so far from having exhausted the readily accessible data upon the subject is the editor, that he can only look upon the result of his labors as a convenient means to an end not yet accomplished. Such remains the case, more particularly, with the Water Birds; in respect of which the very richness of the material of which he has been unable to fully avail himself has been rather an embarrassment than otherwise. While inaccuracies of statement may possibly prove to be few and not serious, very much has been left unsaid through sheer stress of time and space. A volume larger than either part of this treatise might 
easily and most acceptably be devoted to the Water Birds alone of New England. Much is to be expected from the concluding volumes of Baird, Brewer, and Ridgway's "History of North American Birds;" but these are still unpublished; and meanwhile, with the exception of what may be found upon the Waders and Swimmers in the "Birds of the Northwest," now already nine years old, no systematic work upon that extensive and attractive series of Birds has appeared since the Audubonian period. The growing suspicion of fatality, so to speak, which attaches to this matter, might lead an author contemplating the next systematic treatise upon Birds to consider the expediency of beginning at the other end of the current list, and working up from Alcida towards the Turdide.

In the present volume some of the Water-Bird biographies have been pretty fairly elaborated, and special pains have been taken to collate and sift the New England records of the rarer species, whether of the land or of the water, - those casual visitors which, while leaving no decided impress upon our Avifauna, are nevertheless a kind of beings which the ardent collector least delights to entertain unawares. In the cases of these visits, few and far between, the editor regrets still to find himself so frequently at variance with statements of fact and expressions of opinion of late authority upon the subject. Yet, in the end, the fairest reciprocity of authorship - whether regarding one whose hand has left the 
pen, or one whose hand still knows the weapon mightier than the sword - proves to be that sense of justice which tries the amenities of the golden rule by the best touchstone - nil nisi verum.

It is scarcely necessary to say, that, as in the case of the former volume, the author of "New England Bird Life" has in the present instance had full permission to make such use as he might see fit of any of the editor's previous publications; and it has not been necessary, under the circumstances, to always preserve the appearance of quotation. With some exceptions, the illustrations are derived from the same sources. The classification and nomenclature are of course those of the second edition of the editor's "Check List of North American Birds " - that published the past year in Boston by Estes and Lauriat; this selection being made in the interest of a standard and uniform system of nomenclature, conformity with which seems to be the best means of avoiding that incessant "shuffling of names" which serves chiefly to confuse the student, and by so much to interfere with his progress in the delightful study of ornithology.

E. C.

Smithsonian Institution, Washington, D. C., Jan. I, I883. 


\section{BIRDS OF NEW ENGLAND.}

\section{FAMILY TYRANNID $Æ$ FLYCATCHERS.}

THE First Part of our work has been devoted to the Singing Birds, technically known as Oscine (or melodious) Passeres, which are so numerously and variously represented in New England that a volume has scarcely sufficed to exhibit their habits and characteristics. But having finished our pen-portraiture of that great group, including nearly one-half of the birds of New England, we turn our attention to other aspects of bird-life, which offer us much greater variety and certainly not less interest. Part Second continues directly with the Clamatorial (or non-melodious) Passeres, represented in New England, as they are elsewhere in North America, by the single family Tyrannida.

Flycatchers abound in the warmer parts of America, where the genera and species, no less than individuals, are most numerous. Only twelve kinds, however, are found in New England; three of which are merely stragglers from the West and South, having each been observed but once over our border, while a fourth has only recently been ascertained to occur at all. But the remaining eight species are more or less familiar and abundant birds of our country during the migrations and in the breeding season. 


\section{SWALLOW-TAILED FLYCATCHER. \\ Milvulus forficatus $(G m$.) Sw.}

Chars. Tail much longer than the body, deeply forficate. First primary emarginate. Crown with a flame-colored patch. General color hoary-ash, paler or white below, with patches of scarlet or bloody-red on the sides, and other parts of the body tinged with the same or a paler shade of red. Tail black, several of the feathers extensively white or rosy. Wing about 4.50 ; tail nearly a foot long when fully developed.

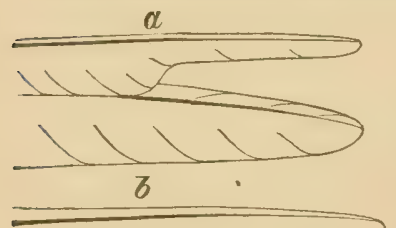

This very elegant and graceful bird of the southwestern United States, abundant and conspicuous in Texas, is one of the three Flycatchers which have accidentally occurred in New England, each in a single instance. A specimen was taken by Mr. Carpenter, at Wauregan, Conn., about April

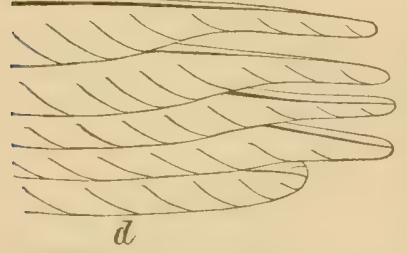
27, I 876 (Purdie, Bull. Nutt. Club, ii, I877, p. 2 I ; Merriam, B. Conn., I877, p. 50). Another equally exceptional case is that recorded by Dr. C. C. Abbott (Am. Nat., vi, I872, p. 367 ), a specimen having been secured at Trenton, N. J., April I 5, I872. Drs. Coues and Prentiss include the species in their list of the birds FIG. I,-Emargination of primaries in of the District of Columbia;
Tyrannide. a, Milluulus forficatus; but that record being propb, Tyranius carolinensis; c, $T$. verticalis; $d$. T. vociferans. erly open to doubt, the above 
remain the only authentic instances of the occurrence of the species so far beyond its usual range.

\section{ARKANSAS FLYCATCHER.}

Tyrannus verticalis Say.

Chars. Several outer primaries gradually attenuate for a long distance. Coloration olivaceous and yellow. Belly and under tailcoverts clear yellow, the back ashy-olive, changing to clear ash on the head, throat, and breast, the chin whitening; lores and auriculars clusky; wings dark brown with whitish edging; tail blackish, the outer web of the outer feather white. Bill and feet black. Length, 8.00-9.00 ; extent, I6.50; wing, nearly 5.00 ; tail, about 4.00 ; bill, $0.65-0.75$.

Another straggler to New England, this time from the West instead of the South, the Arkansas Flycatcher being chiefly a trans-Mississippian bird, extremely abundant in its proper habitat. It has occurred in New England in only one known instance. The late Dr. Henry Bryant recorded a specimen said to have been taken at Plympton, Maine (Pr. Bost. Soc. Nat. Hist., x, 1865, p. 96). There being no such place, Dr. Brewer presumed Pembroke, Maine, was meant, and so amended the record (Pr. Bost. Soc. Nat. Hist., xvii, 1875, p. 443). Mr. Purdie later gave the correct reference, the specimen having been taken at Elliot, Maine, by Mr. George E. Brown (Bull. Nutt. Club, i, I876, p. 73).

Dr. W. P. Turnbull has instanced the occurrence of the Arkansas Flycatcher at Moorestown, New Jersey (B. E. Pa., I 869, p. 4I). Mr. E. P. Bicknell notes the capture of a specimen in Riverdale, N. Y., Oct. 9, I875 (Bull. Nutt. Club, iv, I879, p. 60). A fourth instance 
of the appearance of this western bird beyond its usual range is cited by Prof. Baird in the Smithsonian Report for 1874, p. 32, where notice is given of a specimen taken in Maryland, near Washington, D. C., and found in market in that city, Sept. 30, I874, by Mr. P. L. Jouy. These are all the cases of the kind which have come to our notice.

\section{GRAY KING-BIRD.}

TyRannus Dominicensis $(G m$. Rich.

Chars. Similar to $T$. carolinensis. Larger; length about 9.00 ; extent, 16.00; wing, 5.50 ; tail, nearly 5.00 , emarginate; bill an inch long, very stout and turgid. Five or six primaries usually emarginate. Upper parts grayish-plumbeous, rather darker on the head, the auriculars dusky. Under parts white, shaded with ashy on the breast and sides, the under wing-coverts faintly yellowish. Wings and tail dusky, edged with whitish or yellowish, the tail-feathers merely indistinctly lighter at their tips, not broadly tipped with white.

The proper habitat of the Gray King-bird is the West Indies and Florida, whence it occasionally strays northward. It has once occurred in New England, having been taken at Lynn, Mass., Oct. 23, 1869, by Mr. Charles Goodale, as recorded by Allen, Am. Nat., iii, I 870 , p. 645 ; Maynard, Nat. Guide, I870, p. I24; Brewer, Pr. Bost. Soc. Nat. Hist., xvii, I875, p. I 44 ; Allen, Bull. Essex Inst., x, I878, p. I9; Minot, B. N. E., I877, p. 273,-all these records referring to the same instance. The bird is said to have also occurred on Long Island (Forest and Stream, July 23, 1874, p. 373). 


\section{KING-BIRD; BEE-MARTIN.}

\section{Tyrannus carolinensis ( $L$. $) B d$.}

Chars. Subcrested; crown with a flame-colored patch ; two outer primaries emarginate. Above blackish-ash, blackening on the head; below pure white; breast shaded with ashy; tail broadly tipped with white; bill and feet black. Length, about 8.00 ; extent, I4.50; wing, 4.25-4.50; tail, 3.50 ; bill, less than I.00.

No one of the Flycatchers is more abundant in New England than this tyrant, nor is any one of them so conspicuous a figure on the highways and in the by-ways alike. The spirited creature is dispersed over all our country, and therefore characteristic of no faunal area; but, in its local distribution, it is

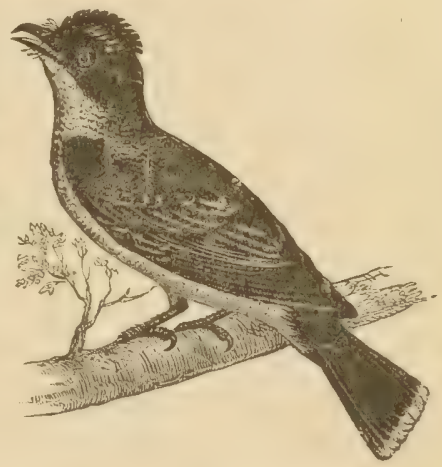

Fig. 2. - KING-BIRD. most numerous in cultivated and populous regions, so that the greater number of individuals in New England is constantly under the eye of man, whose regard is returned with cool audacity and entire self-reliance. The vehement twittering, with which the King-bird expresses the turbulent passions it feels, is one of the common sounds of the orchard, old field, and road-side, wherever the bold bird perches with martial bearing in wait for its prey, or nervously dashes in the air on quivering pinion to capture the passing insect, or put an enemy to rout. The notes have been likened to those of Swallows, but they are harsher, and pitched in a higher key. During the 
mating season few birds, if any, make more noise than the King-bird, and none are more restless, - some uneasy spirit seeming to urge this valiant knight to incessant deeds of daring, till one might fancy it ready to tilt against a windmill if nothing else offered. After the animated contests of the pairing season, when several ambitious males, with questionable judgment, quarrel for the privilege of securing a vixenish partner, - after these tournaments are over, one would think that peace might reign; but the King-bird's life is mostly passed in guerilla warfare with every bird that ventures too near, even if it be a Crow, Hawk or Owl, many times its superior in all things excepting audacity. Brooking no intrusion or division of kingdom, the courageous bird deserves its title, and by right of conquest wears the insignia of royalty, - tyrant by name and nature, and literally crowned with fire, kindled in the alembic of an ardent heart.

Being exclusively insectivorous, like all of its tribe, the King-bird must enter and leave New England with the appearance and disappearance of the winged hosts upon which it preys. Occasionally, an avant-courier is seen in April, and even by the middle of that month; but it is usually the first or second week in May when the dashing bird begins to sound shrill challenge and display its flaming crest, with defiant shaking of its feathery lance. Great numbers press after; the quota is soon filled; and no sooner is the migration finished than pairing and nesting commence with all the pomp and circumstance I have described. The fabric is generally completed by the first of June; and the situations chosen for the nest are such that few specimens of bird-architecture are more exposed to public view. It is usually placed in an 
orchard or garden, or by the wayside, on a horizontal bough or fork at a moderate distance from the ground, and being bulky as well as openly situated, is as easily found as that of a Robin. It is ragged and loose exteriorly, but well cupped and brimmed, and may consist of twigs, weedstalks, grasses, rootlets, leaves, moss and plant down, with or without hair-lining, - the soft, fluffy substance being matted or felted together in an ingenious manner. The eggs are usually four or five in number, and very handsomely colore 1 , being rich creamy-white, artistically spotted and blotched with dark brown, light reddishbrown, and lilac, chiefly in large bold pattern, the markings themselves sharp-edged and distinct, as well as so heavy in color. The eggs are consequently not likely to be mistaken for those of any other bird. They measure about $\mathbf{I} .00 \times 0.75$, being thus quite rotund: but there is the usual variation in size and shape. If one would realize the courage and pugnacity of this redoubtable bird, he has only to offer to molest the freighted nest, and see with what vigor and persistence - with what outcry and at what risk of danger the threatened invasion will be resisted, even if ineffectually, by the devoted and determined parents. But if no such misfortune happens, the brood is safely hatched and reared; and then one of the most pleasing aspects of the King-bird's life is witnessed in the zealous assiduity with which the young are encouraged to leave the nest and taught to use their tremulous wings. These duties and pleasures continue through the greater part of the summer, and then there is a little period of comparative quiet in the camp before young and old alike, with the failure of their supply of insect food, make off for the South during the latter part of September. 


\section{GREAT CRESTED FLYCATCHER.}

\section{Myiarchus crinitus (L.) Cab.}

Chars. Head crested, but no colored crown-patch; no primaries emarginate. Upper parts olivaceous; throat and fore-breast pure ash; other under parts bright yellow; primaries conspicuously edged with chestnut; tail feathers dusky, with nearly the whole inner webs chestnut; bill blackish; feet black. Length 8.509.00 ; extent, I3.00-1 3.50 ; wing and tail, each, about 4.00 ; bill and tarsus, each, about 0.75 .

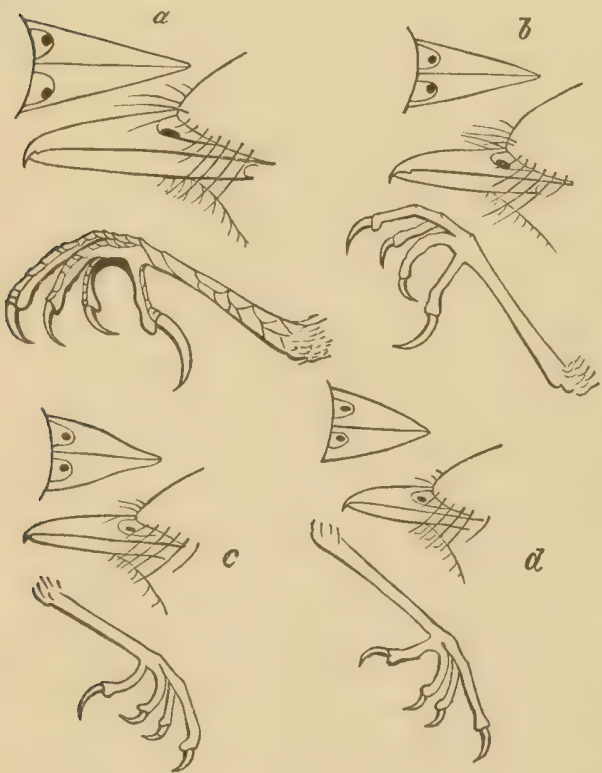

Fig. 3.- Generic details of smaller Flycatchers: a, having numerous Myiarchus; b, Sayiornis; c, Contopus; d, Empido-species in Central nax.

ica, but only one which occurs in the United States at large. If, therefore, it were a bird of migration 
and distribution so regular as to characterize certain faunal areas, we should expect it to be represented equally and numerously in southern New England, and sparingly or irregularly further north. As a fact, however, it appears to be nowhere very abundant, and yet to be dispersed with what may be called "regular irregularity" in all the six New England States-its distribution being according to locality without special reference to latitude. Again, there is something capricious as well as fortuitous in its movements - for its numbers seem to increase or diminish in particular localities in different years, and it may even disappear entirely from places where it had formerly been observed, or be seen some years in other regions where there had been no previous records of its appearance. To sum the case in few words, we may say that this Flycatcher is locally distributed in nearly all New England, but by no means throughout that country; and that in most places where found at all it is rather a rare bird. It is of course only a summer visitor; it arrives early in May, and departs usually before the end of September.

Though Nuttall spoke of the Crested Flycatcher as nearly unknown in New England, and Linsley mentioned the only individual he ever saw in Connecticut, Mr. Merriam says that now it is certainly a really common bird in the southern part of that State at least; adding that we must remember that Nuttall and Linsley were probably not familiar with its characteristic - almost diagnostic - note. "My experience with the bird," he states, "has been, that it is rarely seen, unless, guided by its note, it is persistently followed up; and even then, one is almost at his wit's end to get a shot, so well does the bird keep concealed amongst the foliage." In fur- 
ther evidence of the manner of the bird's presence in Connecticut, I will quote again from Mr. Merriam: "Mr. W. W. Coe, who early became familiar with the note of this species, tells me it has been a common bird in the vicinity of Portland, Conn., for at least fifteen years ever since he commenced collecting birds. Prof. William D. Whitney, of New Haven, informs me that he has known the bird for at least thirty years, and that he has always regarded it as common. His observations extend over portions of Massachusetts (about Northampton), as well as Connecticut. Mr. J. N. Clark, of Saybrook, Conn., says that it was not rare, about the mouth of the Connecticut, twenty-five years ago; and Dr. Wm. Wood, of East Windsor Hill, Conn., tells me that it has bred regularly, and has not been uncommon in that vicinity for the last twenty-five or thirty years." (B. Conn., I 877 , p. 52.)

In Dr. Coues' List of the Birds of New England, the species is noted as a "summer visitant; rather rare" (Pr. Essex Inst., v, I 868, p. 264). Dr. Brewer's Catalogue says, "rare summer resident" (Pr. Bost. Soc., xvii, I 875, p. 443). Mr. Allen's Massachusetts list mentions the bird in identical terms (Bull. Essex Inst., x, I878, p. I9). "The birds reach Massachusetts," says Mr. Minot, "about the middle of May, and ordinarily remain there four months" (B. N. E., I877, p. 275). In Maine, both Mr. Verrill and Mr. Boardman give the species as rare, the one at Norway, the other at Calais. Mr. Brewster has latterly found it a regular summer visitor to the Umbagog Lake region, where it was not ascertained to occur in 187r. In Vermont, Mr. C. S. Paine has found it about Randolph. In the region about Hamilton, Canada West, it is noted by Mr. T. McIlwraith to be a 
common summer resident. An extension of the bird's range of late years has been observed by Mr. Merriam, who, referring to some remarks by Mr. T. M. Trippe on the irregular migrations of birds (Am. Nat., vii, I $\$ 73$, p. 390), records a parallel case, in the instance of this very species occurring in Lewis County, northern New York. "There, prior to the year I870, they were unknown, at least so far as I can ascertain, and it is safe to say that they were extremely rare. In I870, my cousin, Mr. C. L. Bagg, shot one specimen, the first we had ever seen. During the next season I shot a pair. I was away from home in I872, but Mr. Bagg informs me that he took several Great Crested Flycatchers that year, and that they were quite common. In August, I873, I shot eight in about an hour's time, and since then they have been one of our commonest species, breeding abundantly in the tall maple and birch forests, where their characteristic, but rather harsh cry, may be heard at any hour of the day throughout the entire season." (B. Conn., I 877 , p. 5 I.)

While it is scarcely needful to multiply citations in the case of so generally if irregularly distributed a species, the reader may be referred to the results of Mr. H. A. Purdie's observations, in Am. Nat., vii, I 873, p. 692 ; and Bull. Nutt. Club, i, 1876 , p. 73 ; ii, 1877 , p. I6; as well as to those of Mr. R. T. Morris, in Forest and Stream of May I4, I874, p. 2 I 3 ; of Mr. F. W. Hall, in the same paper, of Dec. 3, I874, p. 261 ; and of "G. G. H. Jr.," also in the same paper, Aug. 23, I 877, p. 44.

Comparatively few persons are familiar with the habits of this bird, as it is not one which courts the society of man, but prefers to keep aloof in the depths of the forest, where it leads a wild, shy, and solitary life. It may be 
recognized by its singular notes - one a harsh, explosive outcry of one syllable, pitched in a high key, and others sounded in guttural tone two or three times - all suggestive of the bird's irritable and impulsive nature. It keeps for the most part high up among the trees, where it may be observed perched on the end of a dead branch in the attitude so characteristic of its tribe with drooping or swaying tail and listless air - to be exchanged in an instant, however, for quick and spirited action, should anything excite its attention, or provoke its anger. It is an extremely pugnacious bird, and the combats of the males in the breeding season are almost incessant. Its forays for passing insects are executed with great verve and adroitness, and at other times the bird may be seen dashing at a high rate of speed through the tree-tops. Under any excitement the crest is erected, and the wings are held quivering in readiness for instant action.

Our Flycatchers are without exception distinguished by some peculiarity of nidification, and the nesting of the present species is in a manner quite its own. It builds in the hollows of trees, and the cast skins of snakes are almost invariably found among the materials which compose the nest. Post-holes, and even artificial retreats, such as Blue-bird or Martin boxes, are sometimes occupied. The eggs, four or five in number, measuring about 0.85 by 0.62 , are unique in pattern of coloration, of which it is difficult to give an adequate description. Upon a buff or rich clay-colored ground are drawn lengthwise numberless markings of dark purplish-chestnut, or purplish-chocolate, mixed with others of a paler and more lilaceous tint - these markings being mostly of a peculiar sharp, scratchy character, as if done with a fine pen. At 
the greater end of the egg the tracery becomes more expansive and somewhat confluent, but the scratches, which cover the whole surface, are for the most part distinct; they mostly preserve their longitudinal character, but in some specimens they run in every direction. This remarkable style of egg obtains in all the North American species of the genus, and may be as truly a generic character as is any one of those derived from the birds themselves. It would not be surprising to learn that it is related to some peculiarity of the minute anatomy of the oviduct.

\section{PEWEE; PEWIT; PHCEBE-BIRD.}

Sayiornis fusca (Gm.) Bd.

Chars. Head sub-crested, without colored crown-patch, and no primaries emarginate. Above, dull olive-brown, becoming quite blackish on the head; below, soiled whitish or very pale yellow, brightest on the belly and under tail coverts, shaded on the breast and sides with grayish-brown. Wings and tail dusky; the outer tail feathers and inner secondaries edged with whitish; a whitish eye-ring; bill, eyes and feet, black. Late summer specimens, in worn plumage, are quite dull and dingy. Autumnal birds are brighter-colored than in spring. Very young birds have rusty edgings of the feathers, especially those of the wings and tail. Length, 6.75-7.25; extent, II.00-II.75; wing, 3.253.50; tail, about the same, emarginate; bill, $0.50-0.55$, little depressed, not so broad for its length, or so much flattened, as in Contopus and Empidonax, its lateral outlines straight; tarsus equalling or exceeding the middle toe and claw, these together, about 1.33 ; point of wing formed by the second-fifth quill, third and fourth usually a little the longest ; first shorter than sixth.

Having left the larger Flycatchers, we enter with this species upon the "little tyrants" - Tyrannulas, as they 
used to be called: small olivaceous Flycatchers, without very strong distinctive coloration, or any bright tints whatever. The present, though the only one of its genus in New England, and well marked in the char: acters above given, requires careful discrimination, in the hands of the novice, from any of the species of Contopus or Empidonax. Closely related, however, as it is to these in physical characters, it differs so much in habits, in notes, in nesting, and almost every particular of its life-history, as to make in our bird-life quite a figure of its own.

It is a summer visitor to New England, like all the family; but it comes earlier and lingers later than any other, being found in seasons so umpropitious that one wonders where it finds the necessary supply of insect food; and in fact at some seasons berries form a part of its food. It is one of the very first birds to presage the opening year, - the very harbinger of spring. Before that season is crowned, the bird is on the alert, and its sharp, querulous "pcrvit-pervit" seems to complain impatiently of the tardy march of nature forth from bondage into freedom. An occasional Phobe-bird may appear even in February; some come by the middle of March; by the end of that month there are plenty, and it is well through October before the loitering hosts have disappeared. For the greater part of the year, therefore, Pewits make their homes in New England; they are common, in most places abundant, and not restricted by latitude in their distribution; and being also very familiar birds, are among those best known to all classes.

Civilization has effected in this case the same change in the nest-building of a bird that has resulted in the more conspicuous instance of the Swallows, by affording 
artificial nesting sites so convenient that the bird habitually avails itself of these facilities. The original "typical" situation is the side of an upright rock, usually over water, and often itself dripping; the nest being affixed either to the open face of the stone, or beneath a projecting shelf, or in a cranny or retiring angle. Other sites frequently selected are the sides of earthen embankments or cuts, such as a Bank Swallow or Kingfisher might burrow in; or the roots of upturned trees, with plenty of earth clinging to them. The eaves and rafters of buildings now furnish the usual substitutes. The nest resembles a fourth of a sphere, applied by a vertical flat surface to the support, with another surface horizontal and hollowed out - the curved contour being somewhat elongated downward. The nest is built, like that of the Barn Swallow, of mixed mud and vegetable substances, but is much neater and more compact; moss usually enters largely into its composition, and those nests which are placed on wet rocks near the water, in the cool, moist, shady nooks the bird loves so well, are often composed chiefly of moss and mud, which may be artistically stuccoed with lichens. Two and even three broods may be reared under favorable conditions in one season. The first set of eggs is usually completed early in May, and another some time in June. The eggs are ordinarily four or five in number, measuring about $0.70 \times$ 0.52 ; they are normally pure white and unmarked, though in some cases sprinkled with a few dots. The attachment of the Pewit to particular places is a marked trait. A pair will return year after year to re-occupy the same home in preference to any other equally eligible nesting site ; and their perseverance in building under the most discouraging circumstances is no less remarkable. 


\section{OLIVE-SIDED FLYCATCHER.}

Contopus borealis $(S w) B$.$d .$

Chars. Head sub-crested; feet extremely small; tarsus shorter than middle toe and claw; pointed wings much longer than the emarginate tail. Length, 7.00-8.00; wing, 3.90-4.30 ; tail about 3.00; tarsus, middle toe and claw, together, only about 1.25; bill, o.66-0.75. Dark olive-brown, usually darkest on the crown, and palest on the sides; chin, throat, belly, under tail-coverts, and middle line of breast, white, or whitish ; wings and tail blackish, with whitish edging of the inner quills; upper mandible and feet black. The olive-brown of the under parts has a peculiar streaky appearance; there is a tuft of fluffy white feathers on the flank.

This is much the largest of the olivaceous Flycatchers, nearly equalling a Myiarchus in dimensions; but its form is strictly that of the Wood Pewee. Though not characteristic of any faunal area, it is more abundant in the Canadian than in the Alleghanian, and in the breeding season quite rare in the Carolinian; that is to say, it grows more and more numerous in summer as we proceed northward in New England. Thus, for Connecticut, Mr. Merriam furnished in 1877 the first record subsequent to the doubtful one made in $\mathbf{I} 843$ by Linsley: "Rare; probably a few breed in the more northern and hilly parts of the state, as they are known to do in Massachusetts. On the I 8 th of October, I 875 , attracted by its characteristic note, which is a short whistle, resembling the syllables 0 -wheo, o-whco, o-wh wco, uttered several times in succession, with the voice falling on the last 0 , I caught a momentary glimpse of one, perched on the top of a tall tree; but the bird was very shy, and I did not succeed in getting a shot. Mr. Erwin I. Shores 
writes me that he took a male at Suffield, Conn., Aug. 8, 1874. This is strong evidence of their breeding in the hills about that portion of the state, for migrants would hardly appear in Connecticut during the first of August." (B. Conn., I 877, p. 53. See also his notes in Am. Nat., vii, I873, p. 750 , and viii, I874, p. 309; also R. Deane's, ibid, p. 308.) The Connecticut record being thus so meagre, the time of the entry of this migratory bird into New England cannot be given with precision. It is one of the later arrivals, however, apparently not reaching Massachusetts before the second week in May, and leaving its summer resorts rather early in September. In that state, different observers have called it a "rare summer resident," a "rather uncommon summer resident," "neither rare nor common," and "quite common," according to different localities and circumstances of observation. It is marked as "quite common and breeding" at Umbagog Lake, in Maine, by Messrs. Maynard and Brewster, and Mr. G. A. Boardman speaks of its "abundance" some seasons in the vicinity of Calais, in the latter state. We also have records to corresponding effect from Vermont and New Hampshire.

The Olive-sided Flycatcher is confined to no particular kind of ground, but may be observed in orchards and gardens, or groves of evergreen trees, as well as in the depths of pine forests. In Massachusetts, it is partial to pitch pine groves, especially during the breeding season. Wherever found it is likely to become a conspicuous object from its habit of perching in exposed situations upon the ends of dead limbs, or blasted treetops, whence it utters its loud characteristic notes and makes its spirited sallies after passing insects, returning to the same post of observation. Nesting is essen- 
tially similar to that of the Wood Pewee, the structure being saddled on a horizontal limb, or fixed in a fork, often at a great height from the ground. The nest is a shallow, saucer-like fabric of twigs, rootlets, weed-stalks, bark-strips and other similar material, rather loosely put together. The very handsome eggs are of a pure creamy white, speckled with brown or reddish and lilaceous shades; they are four or three in number, measuring about $0.85 \times 0.65$, and are laid from the last week in May, as in Massachusetts, to middle of June in Maine.

\section{WOOD PEWEE.}

\section{Contopus virens (L.) Cab.}

Chars. With the form and proportions of the last species, but much smaller. Length, 6.00-6.50; wing, 3.25-3.50 ; tail, 2.753.00 ; tarsus, middle toe and claw, together, scarcely or not I.00; tarsus alone, about 0.50 , thus no longer than the bill; no evident white tuft on the flank; head sub-crested, with erectile feathers. Olive-brown, rather darker on the head; sides with a paler shade of the same, reaching nearly or quite across the breast; the throat and belly whitish, more or less tinged with, yellowish; under tail-coverts the same, usually streaked with dusky; tail and wings blackish, the secondaries and coverts edged and tipped with whitish; feet and upper mandible black; under mandible usually yellow, sometimes dusky.

In numbers according to latitudinal distribution the well-known Wood Pewee presents the reverse state of the case just outlined for the Olive-sided Flycatcher, being most abundant in southern New England, and gradually becoming less numerous as we proceed northward. Nevertheless, it is one of New England's very com- 
mon birds, and inhabits all of the country. As its name indicates, it is partial to forests, and on the whole is of a retiring and unfamiliar disposition, though far from shy, and often surrendering the pleasures of solitude for those of society in the orchard or garden. Wherever it may fix its home, whether in the seclusion of sylvan retreats or in the vicinity of man's abode, its presence is soon made known by its oft-repeated melancholy notes, seeming to speak some settled sorrow that time can never heal. The sighing of the pines is not more expressive of mournful fancies than the sobbing of the little sombre-colored bird, flitting apparently inconsolable through their shades. But we need not be moved to pity by the anatomical configuration of a bird's windpipe. Let us stick to science, and leave the sham of things to poets. The Pewee is a very practical and doubtless happy bird, brimful of active energy, constantly exhibited in the forays it makes after winged insects that venture too near its perch, and in the nervous way the wings flutter before and after these spirited excursions, while the lengthened feathers of the crown are alternately erected and depressed with the changing mood of the irritable creature.

Quite the opposite of its relative the Phœbe-bird, the Wood Pewee is a loiterer by the way in spring; though it seems in no particular haste to depart with the waning scason. It is in fact one of the latest arrivals among our summer guests - very fashionable in this respect. It scarcely enters Connecticut before the middle of May, and is not generally dispersed over the country before June. The return movement may begin early in September, in more northerly sections, but is not completed till the end of that month. Nesting is correspondingly 
delayed, the average time being not before the middle of June. The nest is very pretty - a flat, compact, circular structure, with thick walls and well-turned brim, but very thin flooring, closely saddled on a horizontal bough, or set in a forked twig. It is neatly finished on the outside with lichens, like that of the Blue-gray Gnatcatcher or Humming-bird, so as to be effectually concealed from casual search by its resemblance to a natural excrescence of the limb. The principal materials are fine grasses, slender bark-strips and rootlets, circularly disposed, and often fastened with silky or cottony threads. The precise structure of its nest will vary, of course, according to the site selected: the saddled nests being scarcely more than walls of which the bough itself furnishes the basement; while nests in forks are furnished with more substantial flooring. The elevation above the ground is another variable element, being sometimes only ten or twelve feet, while in other (and more usual) cases the birds build high up in tall trees. Under any circumstances, however; the nest may be recognized by its shallowness, with its thick, compact, lichen-stuccoed walls, and its spotted, creamy eggs. The eggs, to the usual number of four or three, measuring about $0.70 \times$ 0.55 , are creamy white, blotched with the usual shades of reddish and darker and more lilaceous brown, the markings being often wreathed about the larger end. Notwithstanding the procrastination of the bird in building, more than one brood may be reared under favorable circumstances. 


\section{ACADIAN FLYCATCHER.}

\section{Empidonax acadicus $(G m$.) $B d$.}

Chars. Above, clear continuous olive-green, rather darker on the crown, where the feathers have dusky centres; below, whitish, shaded with olive on sides and nearly across breast, washed with yellowish on belly, flanks, and under wing- and tail-coverts; wings dusky, the coverts tipped, and the secondaries edged with tawny yellow; tail dusky, glossed with olive; a yellowish eye-ring; feet and upper mandible brown; under mandible pale. The largest of this genus. Length, 5.75-6.25; extent about 9.50; wing, 2.75-3.00; tail, 2.50-2.75; bill, nearly or quite 0.50 ; tarsus, 0.66 ; middle toe and claw, 0.50 ; point of wing reaching nearly 1.00 beyond the secondaries; Ist quill much longer than 6 th.

Notwithstanding the suggestive name, the "Acadian" Flycatcher is scarcely a bird of New England, and much misunderstanding has resulted from reliance upon erroneous records of its supposed occurrence in New England. It should be remembered that it is now scarcely more than twenty years since Prof. Baird first accurately distinguished the four eastern species of Empidonax, concerning which the greatest confusion and uncertainty had before obtained. Passing over all the earlier records which, whether having any basis of fact or not, are too indeterminate for use, we may note the steps by which we have reached the true state of the case. In the first general list of New England birds, Dr. Coues speaks of the Acadian Flycatcher in the following terms :-

"Summer resident. Not abundant. This species seems to be more restricted in its northern range than the others of the genus, apparently not proceeding much farther than Massachusetts. It is not, I believe, recorded 
from Maine. But Mr. Samuels erroneously omits it from his Massachusetts list. Earlier authors speak of it as being very common, but so far as I can learn it is quite rare. At Washington, D. C., it is by far the most abundant species of the genus." (Pr. Essex Inst., v, I 868, p. 264).

This is an inkling of the truth, in recognizing the restricted southerly habitat of the bird in comparison with its congeners, and would appear to be well-founded, viewing the many New England records upon which it was based; among them that of so careful and reliable an observer as Mr. Allen, who had confidently attributed the species to Massachusetts (Pr. Essex Inst., iv, I 864, p. 54). The uncertainty of the case was soon after remarked by Dr. Brewer (Am. Nat., i, I867, p. I19), who later communicated to Dr. Coues a note on the subject, which was published in the Birds of the Northwest. "I do not think the bird occurs in New England, even in the Connecticut Valley, and believe that Mr. Allen has mixed it up with traillii. I have myself no evidence of its breeding northeast of Philadelphia; but it is shy and retiring in its habits, and would readily escape notice, so that its presence in New Jersey, New York, and New England may not be uncommon, and yet we not know it." (B. N. W., 1874, p. 25I.) In the same work (p. 250) it is stated that the bird "remains to be detected in New England." Dr. Brewer, therefore, very properly expunged the species from his catalogue of 1875 , with the following statement: "Mr. Allen informs me that the species found in western Massachusetts, and included by him in the list as the Acadian Flycatcher, is really Emp. Traillii. This leaves us without any evidence of the occurrence of the species, 
and I have therefore taken it from the list" (Pr. Bost. Soc., xvii, I 875, p. 452).

In 1876 , in a paper "on two Empidonaces, traillii and acadicus" (Bull. Nutt. Club, i, I876, pp. I4-17), the subject was well handled by Mr. Henshaw, with special reference to the differences between the species named in geographical distribution, nesting, and eggs. Then, after it had been made out to every one's satisfaction that the bird had never been known to occur in New England, the claim of this characteristic component of the Carolinian fauna to a place among the birds of New England was immediately proven by Mr. C. H. Merriam, who marked it in his list as "a rare summer visitant from the middle states," adding that "it may breed in the Connecticut Valley" as is doubtless the case. "It affords me great pleasure," he continues, "to be able, through the kindness of Mr. Erwin I. Shores, to replace this species among the birds of New England. As is well known, it was formerly included in [nearly] all New England lists, but, as shown by Dr. Coues, Mr. H. W. Henshaw, and others, the records were founded on erroneous identifications - the bird having been mistaken for E. minimus or Traillii, generally the former. . . . Hence it was with a peculiar sense of gratification that I received, a few days since, an unmistakable example of the species, from Mr. Shores, who relates that he shot it in "Suffield, Conn., June 24th, I874, in a piece of woods known as Beech Swamp.' For the benefit of those who may not be disposed to accept my identification in so important a matter, and to avoid all possibility of mistake, I at once sent the bird to my friend, Mr. Robert Ridgway, of the Smithsonian Institute, and he pronounces it to be a 


\section{typical E. acadicus." (B. Conn., I877, p. 58.) This} species was soon after restored to its rightful place by Dr. Brewer (Pr. Bost. Soc., xix, I878, p. 306).

Dr. Brewer states that the nest of the Acadian Flycatcher "is generally placed on a drooping limb of a beech or dogwood tree, at a height of from six to ten feet from the ground. It is never saddled on a limb like that of a Wood Pewee, neither is it pensile like that of the Vireos, but is built in the fork of a small limb, and securely fastened thereto by a strip of bark. The nest itself is mostly made of fine strips of bark or weed stalks, woven together without much care as to neatness or strength, and so slight is the structure that you may often count the eggs in the nest from below. Occasionally the bird constructs its nest of the blossoms of the hickory-tree, and when thus made, it is very neat and pretty." (Hist. N. A. Birds, ii, 1874, p. 376.)

Mr. Henshaw's article compares the nest with that of E. traillii to find a very striking difference. "It is a slight structure made of fine grasses, interspersed more or less with the blossoms of trees, the whole disposed in a circular form and fitted between two twigs; a firm support is derived from a binding of spiders' webs, which are interwoven with the sides of the nest, and then carried over the twigs on either side, encircling them with strong bands. The entire base of the nest is without support, and so thin is the slight structure that the eggs might almost be seen from below. It was built in a small tree, perhaps twenty feet from the ground. In this respect the two species vary but little, both preferring to select the lower branches of tree or shrub for their domicile, and only rarely departing from the rule." (Bull. Nutt. Club, i, 1876, p. I6.) 
This account of the decided peculiarity of the nest is endorsed by Dr. Coues, upon examination of specimens sent to him from Missouri. "Two nests of this species are strikingly different from those of trailli in structure, in materials, and in position. They appear to have been taken from long, slender horizontal branchlets, in the horizontal forks of which they rest. They are shallow nests, - in fact, rather saucer-like than cupped-shape, some three and a half inches across outside by less than two inches in depth, the cavity over two inches across the brim, by scarcely one inch in depth. They are very light, 'open-work' structures, so thinly floored that the eggs may have been visible to one looking up from below; and the walls, though more compact, still let daylight through on all sides. These nests, in short, may be compared to light hammocks swung between forks. Each is composed almost entirely of long walnut aments, which, drooping in slender sprays from all sides, give a tasteful, airy effect to these pretty structures. There is a slight lining in each case of slender grassstems and still finer rootlets, loosely interlaid in every direction on the bottom, rather circularly disposed around the brim. These specimens were taken June 13 and 18 , I 879, in hickory woods, at altitudes of ten and fifteen feet." (Bull. Nutt. Club, v, I880, p. 23.)

According to the same authority the eggs of acadicus are so similar to those of trailli that no one should presume to tell them apart with any show of confidence. They are said to be only three in number. Dr. Coues also gives the following rules for distinguishing the four eastern species of the genus, when site and structure of nests and character of eggs are together taken into consideration :- 
$E$. acadicus. Nest in trees, in horizontal fork:s, thin, saucer-shaped, open-worked; eggs creamy white, boldly spotted.

E. trailli. Nest in trees, in upright crotch, thick, deeply cupped, more or less compact walled; eggs creamy white, boldly spotted.

E. minimus. Nest in trees, in upright crotch, deeply cupped, compact walled; eggs immaculate white.

E. faviventris. Nest on ground or near it, deeply cupped, thick and bulky; eggs white, spotted.

\section{TRAILL'S FLYCATCHER.}

\section{Empidonax trailli (Aud.) Bd.}

Chars. Above, olive-brown, lighter and duller brownish posteriorly, darker on the head; below, nearly as in acadicus, but darker, the olive-gray shading quite across the breast; wing-markings grayish-white, with slightly yellowish or tawny shade; under mandible pale; upper mandible and feet black. Rather smaller than acadicus. Length, 5.50-6.00; extent, 8.50-9.50; wing, 2.65-2.80; its tip only reaching abont 0.66 beyond the secondaries; tail, 2.50; tarsus, 0.66 ; middle toe and claw, 0.60 .

Traill's Flycatcher is a common bird of Southern New England, in suitable localities, during the migrations, which take place in May and September. It is found chiefly in thickets, copses, and low wet woodland, where it may be recognized by one having a good ear for such things by its peculiar note, likened by Mr. Maynard to the syllables kevoink', not so quickly uttered, and therefore quite different from the abrupt chebec', or sezvic', of the more abundant and more generally diffused Least Flycatcher. Others syllabify the note by 
pretty-dear, with accent on the de. The bird appears to be quite rare in some sections, particularly Eastern Massachusetts, where E. minimus is the chief representative of the genus. According to Mr. Merriam, it is in Connecticut a common summer resident, arriving early in May and frequenting swampy localities, where it breeds (B. Conn., 1877 , p. 58). This may be so; but the difficulty of distinguishing the little Flycatchers is wellknown, and Mr. Purdie writes me that he thinks there must be some mistake about the bird's breeding in Connecticut. For even though Flycatcher nests "like those of the Indigo-bird" have been found in northwestern Massachusetts, the distribution of Traill's Flycatcher in the breeding season is no less characteristic of the Canadian Fauna than is that of several species which have been used to indicate the difference between that Fauna and the Alleghanian.

According to Mr. Henshaw (Bull. Nutt. Club, i, I874, p. 15), the nest of Traill's Flycatcher may be compared fairly with the usual style of the Summer Warbler, so well known to every one, "but lacks something of the compactness and neatness shown by this species in weaving together the materials that make up its home. Hempen fibres compose the exterior, or the bulk of the nest, while internally it is lined in true Flycatcher style with fine grasses, and a slight admixture of down from thistles; the main point of all, however, is its position with regard to the branches. It is built into an upright fork, the small twigs that surround it being made available to secure it more firmly in its place by being encircled with the stringy fibres. In this particular of position correspond all the nests of this bird I have seen, as well as those of pusillus in the West." As Mr. Widmann has observed, 
"upright fork" in this case does not necessarily mean an upright branch, for the limb itself may be horizontal, or even drooping; when the nest will be found fastened to twigs which spring up and form a perfect crotch. Several nests, sent from Missouri by Mr. Widmann to Dr. Coues, are thus described by the latter: "The situation, materials, and whole style of architecture of these three nests are different from those of acadicus, and are identical with those of $E$. minimus (eggs of which latter are pure white, unmarked). They are built in each case on a stouter bough, in the upright crotch formed by two or several twigs springing up from the main stem; very compact, thick-walled and deeplycupped structures, let firmly down into the crotch, - the twigs either grooving the walls, as in one instance, or embedded into the substance of the nest, as in the other two cases. The outside diameter is nearly or about three inches, while the depth in one case is quite as much, but in the other two about half an inch less. The cavity is scarcely or about two inches, with a depth of fully one and a half inches, so deeply cupped are these structures. These nests are stoutly built of slender grasses, rootlets, and a variety of bleached vegetable substances disintegrated beyond recognition. Two are lined with very fine grass-stems or rootlets; a third, with these and horse-hairs; one has some bits of twine worked into the walls, and in another some large feathers, apparently from the poultry-yard, have been similarly used." These nests were taken from an oak, an elm, and an ailanthus, at heights from six to eight feet, on June I 4, I 7 and 2I; one contained three, another four eggs (Bull. Nutt. Club, v, I880, p. 24). On the subject of these trailli nests from Missouri, Mr. Allen writes to $\mathrm{Dr}$. 
Coues as follows: "I could not understand your comparative diagnoses of nests of $E$. trailli and acadicus until Mr. Brewster showed me a series of nests of $E$. trailli from Ohio ; for in New England E. trailli builds an entirely different nest from what it does in Ohio and Missouri. The New England nests (Maine, New Hampshire and Vermont specimens) are scarcely distinguishable from the ordinary nest of Cyanospiza cyanca, and consequently suggest no comparison with the nest of E. minimus, being bulky structures of coarse materials, which no one would think could belong to the species building the small, compact nests of soft materials that come to us from Ohio through Dr. J. M. Wheaton, or from Missouri through Mr. Widmann, such as you describe. It seems to me also noteworthy that E. trailli breeds in the interior so much further south than it does in the Atlantic States; though noted as breeding sparingly as far south as Long Island, it rarely nests in New England south of the Canadian Fauna, or south of central or northern Maine, and corresponding points in Vermont and New Hampshire" (loc. cit., p. 25).*

A similar account of the nesting of trailli in Maine is given by Mr. Purdie, who remarks upon the differences observed in the structure of the nest and its situation from such as Mr. Henshaw's description indicates. "The nest," he says, "is built between the upright shoots of low bushes, from one to five feet from the ground, and is loosely constructed of grasses throughout, including the lining. It is a much less compact nest

* Consult also Pearsall and Bailey, "The Country," i, Apr. zo, 1878, p. 37 I ; Purdie, ibid., ii, Apr. 27, I878, p. 9, and May 4, p. 25 ; Forest and Stream, x, Apr. 25, I878, p. 216 ; May 9, 1878, p. 255. 
even than that of the Indigo Bird, though perhaps smaller in the average" (Bull. Nutt. Club, i, 1876, p. 75). But with whatever variation in degree of compactness and in materials, the structure is still always a deep cup placed in an upright fork, thus essentially like that of minimus, and quite different from that either of acadicus or of a Wood Pewee. The eggs, however, resemble those of the Pewee, and especially of the Acadian Flycatcher, in being creamy white and in being boldly spotted. The markings are of different shades of brown, chiefly at or about the larger end of the eggs. The eggs are three or four in number, measuring about $0.64 \times 0.55$. The tendency in New England seems to be for the bird to build quite low down in bushes, rather than in trees, and in watery situations, such as alder thickets or their vicinity. Mr. C. S. Paine, who seems to have found many nests in Vermont, speaks of them as placed in low alder bushes, three or four feet from the ground, near running streams. According to Mr. Brewster's observations in New Hampshire and Maine, the bird's "favorite haunts were the dense alder thickets along the rivers and small streams, over those dark retreats, perched on some tall dead branch, full in the rays of the noonday sun. The male sang vigorously, occasionally darting out after some insect, and returning to the same perch. His song consisted of a single dissyllabic refrain, $k c^{\prime}$-zoing, uttered in a harsh, peevish tone, at an interval of about thirty seconds, varied occasionally to $k \epsilon^{\prime}$-zuink or $k \varepsilon^{\prime}$-zvinch. At each utterance his head is thrown upwards with a sudden jerk. They were retiring, but not shy; were easily approached, and were apparently not so restless as most Flycatchers " (Hist. N. A. Birds, ii, 1874, p. 371). 


\title{
LEAST FLYCATCHER.
}

\author{
EMPIDONAX MINIMUS $B d$.
}

Chars. Colors almost exactly as in trailli; usually olive-gray rather than olive-brown; whole anterior parts often slightly ashy; wing-markings, eye-ring, and loral feathers plain grayishwhite; feet black; under mandible usually dusky. Smaller than trailli, and not so stoutly built. Length, 4.80-5.50; extent, $7.40-8.30$; wing, 2.60 or less; tail about 2.25 ; bill less than 0.50 ; point of wing reaching only about 0.50 beyond the secondaries.

In New England at large this little Flycatcher is the most abundant of all the species, characteristic of no special faunal area, but commonly and almost universally distributed. On the whole, however, it is more numerous in southern than in northern New England, and may be entirely wanting in some sections of the latter, where Traill's and the Yellow-bellied are the principal representatives. Compared with the other three, it is next to the most southerly - the Acadian scarcely reaching our boundaries, then the Least, so plentiful to Massachusetts and decreasing in numbers northward - then Traill's, reversing the regions of relative abundance - then the Yellow-bellied, not yet found breeding except in Maine. The Least Flycatcher enters Connecticut about the first of May, and soon becomes abundant and generally dispersed in orchards, gardens, parks, and even in the heart of large cities, as well as in woodland anywhere else, thus not particularly affecting the swampy bushy places to which Traill's habitually resorts. It may be known by circumstances of its local distribution, and by its readily recognized 
note, the peculiar chebcc', cadet', or sezvick', of which the various New England writers speak. Remaining through the summer to breed, the little bird migrates southward in September, not entirely withdrawing until about the end of that month.

The nests and eggs of the Least Flycatcher have been described with particularity by Dr. Coues, whose account (Birds Northwest, p. 255) is transcribed in substance. The bird generally nests in a sapling or shrub, ten or twelve feet from the ground, - but sometimes scarcely more than a man's height, and in other instances up to forty feet. The nest is placed in an upright crotch formed by two or several twigs generally no thicker than one's finger. In one case it was on the bending trunk of an elm, but rested, as usual, among a set of upright twigs. It is very deeply let down into the crotch, and usually bears their deep impressions. The female is so close a sitter, ihat sometimes she may almost be taken in hand before she deserts her charge; and then she only flutters to a little distance and moves uneasily about, uttering a low mournful note. The nest is a neat little structure, with a basis of fine fibrous inner bark and decomposed substance of various weeds, matted with plant-down into a soft, warm, yet firm structure, finished internally with a special lining of plant down, confined with a slight layer of horse-hair or the finest possible grass-tops. The frame of the nest is well finished and even, with circular disposition of the fibres composing it, while the lining material is interlaced in all directions. These elegant structures vary in size from two and a half inches across outside and less than two in depth, to nearly three inches in both these dimensions. The cavity is large for the bulk of 
the nest. The eggs are generally four in number, sometimes only three; five were not found in any one of six nests examined. The average size of twenty specimens was $0.65 \times 0.50$, with $0.68 \times 0.52$ and $0.59 \times 0.50$ as the extremes of size and shape. They are pure white, and normally without any markings whatever; but, as in the similar case of the Pewit Flycatcher, occasional eggs are found to be dotted. A case of this kind has been instanced by Mr. R. Hayward, who found a nest in an apple tree at Milton, Mass., containing three normal eggs, and one minutely dotted with reddish-brown, measuring $0.63 \times 0.50$. The identity of this nest is vouched for by Mr. Brewster : it was "like others of this species, and the bird had the well-known note of chebcc." (Bull. Nutt. Club, iv, I879, p. I 24.)

The gradual influence of civilization, which may in time become as marked in the case of this species as it has in that of the Pewit, has been noted by Dr. Brewer with reference to the materials composing the nests. "Those made on the edge of woodlands or in remote orchards are wrought almost entirely of fine deciduous bark, hempen fibres of vegetables, feathers, dried fragments of insect cocoons, and other miscellaneous materials felted or impacted together; within this is a lining of fine strips of vegetable bark, woody fibres, fine lichens and soft downy feathers. In some the lining is exclusively of fine pine leaves, in others with the seeds or pappus of compositaceous plants. Those made in the vicinity of dwellings indicate their neighborhood by the variety of miscellaneous and convenient materials, such as bits of paper, rags, cotton, wool, and the larger and more conspicuous feathers of the poultry-yard. Where raw cotton was abundantly provided, I have known this 
material, strengthened with a few straws and woody fibres, with a lining of feathers, constitute the whole substance of the nest." And again, as to the increasing sociability of the birds themselves: "They are much addicted to particular localities, and return to the same spot year after year, if undisturbed. A pair that had established their hunting-grounds in an open area north of a dwelling in Roxbury returned to the same spot for several successive years, and would come regularly to the piazza of the house, where bits of cotton were exposed for the benefit of such of the whole feathered tribe as chose to avail themselves of it. Each year they drew nearer and nearer to the house, until at last the nest was made in a clump of honeysuckles on a corner of the piazza, whence they would sally forth in quest of insects, entirely unmindful of the presence of the family." (Hist. N. A. Birds., ii, 1874, p. 373.)

\section{YELLOW-BELLIED FLYCATCHER.}

\section{EMPIDONAX FLAVIVENTRIS $B d$.}

Chars. Above olive-green, clear, continuous and uniform, as in acadicus; below decidedly yellow, bright and pure on the belly, shaded with olive on the breast and sides. Eye-ring, wing-manings, and under mandible yellow; feet black. Size of trailli or rather less; feet proportioned as in acadicus; bill shaped nearly as in minimus, but rather larger; first quill usually equal to sixth.

The Yellow-bellied is not so well-known in New England as either of the two foregoing, though the character implied in the name is very distinctive on comparison of 
specimens. It appears to be rather uncommon, is chiefly seen during the migrations, and thus far is only known to breed in Maine. Reaching Connecticut about the middle of May, and to be found there till June, it passes on to its breeding grounds and returns in September. It doubtless withdraws entirely, as a rule, during that month, notwithstanding that specimens have been taken at dates so irregular as November 29 and December I (Bull. Nutt. Club, iii, I878, p. IOI). Mr. C. J. Maynard has apparently had more experience with the species than most observers have enjoyed. In his catalogue of Massachusetts birds he speaks of taking a dozen from May 3 I to June IO, I 869 , eight of them in a few hours on June I. "I do not doubt," he says, "that it has occurred in previous seasons, but, being unaccustomed to its low note, - which is like the syllable pea, very plaintively and prolongedly given, - and its retiring habits, I had not detected it before. The specimens captured were all, - with the exception of the first, which was shot in a tall oak, - taken in low swampy thickets." In another place he adds that he found the bird in clark swamps at Upton, in Maine, where for the first time he heard any other note than the low pea; it was like the syllables killic, very gravely given, with a long interval between each utterance, and much less energetic than the corresponding note of E. trailli. Mr. Purdie endorses the fact that this kil-lic note is not at all like the sound of Traill's voice, but nearer that of the Least Flycatcher. "The pea," he continues, in a letter to the editor, "which I consider to be the song of the species, is given in the style of the Wood Pewee, but is much fainter, and in one syllable instead of two or three, and repeated several times." Although during the 
migration the birds may be dispersed in high or mixed woods, their preference for swamps becomes evident when we know their breeding habits, which may now engage our particular attention.

It has proved no easy task to clisentangle the history of this species from that of its two nearest relatives, considering the conflicting or erroneous accounts which have crept into the books, resulting from wrong identification of nests or other mistakes. Thanks to several active and successful New England observers, the doubt has been dispelled, and the nest and eggs of flaviventris should be as recognizable as those of any other species. One of the most satisfactory accounts, which may be transcribed in part, is that given by Mr. Purdie in the Nuttall Bulletin for October, i878, p. 166. Remarking that Dr. Brewer, and, following him, Dr. Coues, had described the eggs as white, unmarked, he notes his experiences with the bird at Houlton, Me. "Mr. Bradbury informed us that he had found, on June I5, a nest unknown to him, with one egg. On the ISth he conducted us to the edge of a wooded swamp, and pointing to the roots of an upturned tree, said the nest was there. We approached cautiously and soon saw the structure, and then the sitting bird, which appeared to be sunken in a ball of green moss. Our eager eyes were within two feet of her, thus easily identifying the species, when she darted off; but, to make doubly sure, Mr. Deane shot her. There was no mistake; we at last had a genuine nest and eggs of the Yellow-bellied Flycatcher. A large dwelling it was for so small and trim a bird. Built in and on to the black mud clinging to the roots, but two feet from the ground, the bulk of the nest was composed of dry moss, while the outside was faced with beautiful 
fresh green mosses, thickest around the rim or parapet. The home of the Bridge Pewee (Sryomis fuscus) was at once suggested. But no mud entered into the actual composition of the nest, though at first we thought so, so much was clinging to it when removed. The lining was mainly of fine black rootlets, with a few pine-needies and grass-stems. The nest gives the following measurements: depth inside one and a half inches; depth outside four and a quarter inches ; circumference, inside, seven and a quarter inches. The eggs, four in number, were perfectly fresh, rounded oval in shape, and of a beautiful rosy-white tint, well spotted with a light reddish shade of brown."

Mr. S. D. Osborne soon supplemented this excellent account (ibid., p. I 87 ): “On Monday, June Io, I 878 , while collecting in company with Mr. R. F. Pearsall, on the island of Grand Menan, I flushed a Yellow-bellied Flycatcher, which seemed to come from directly under my feet. The locality was a good-sized hummock of moss, in swampy ground at the edge of some low woods. For some time I was unable to find any signs of a nest, but finally I discovered a small hole one and a half inches in diameter in the side of the hummock, and on enlarging this opening the nest, with four eggs, lay before me. The bird, which had all the time been hopping around within a few feet of our heads, was at once shot. The cavity extended in about two inches, was about four inches in depth, and was lined with a very few grasses, black hair-like roots, and skins of berries. The eggs, four in number, are white, with a very delicate creamy tint, which differed in its intensity in different specimens, and are spotted, mostly at the larger end, with a few dots and blotches of a light reddish shade." About a year 
later Mr. Osborne discovered another nest in Oxford County, Me., in a similar situation, with four eggs well advanced in incubation on the 18 th of June. "The nest was built in the side of a hummock of moss, under the roots of a small tree, and was only about half covered over, the eggs being clearly visible from the outside." The eggs were also spotted. (Bull. Nutt. Club, iv., Oct. I 879 , p. 240.)

To place this matter of the lowly nesting and spotted eggs of the Yellow-bellied Flycatcher, by which it differs somewhat from all its eastern congeners, beyond all doubt for the future, I will sum the observations of a third independent observer who himself took two nests, making five in all here described. Mr. C. F. Batchelder's first nest was taken June 14th, I 879, at Fort Fairfield, Me., in wet mixed woods. It was placed on the edge of a bank formed by a decayed tree trunk, over a pool, protected from view by some green moss growing upon a projecting root, and partly sunken in the surrounding moss. The materials were fine brown roots, bits of rotten wood, the scaly coverings of buds, apparently of the arbor vitæ, together with a few sticks and withered leaves, and one or two bits of arbor vitæ and green moss; with fine black rootlets and withered grasses for lining. The outer diameter was four inches, the inner two and three eighths, with an outer depth of two and a quarter, and cavity one and a quarter deep. The four eggs were white, with a slight creamy tinge, spotted and blotched with two shades of light reddish-brown, mostly about the larger end; two of the eggs also having a few fine dashes and specks of black over the other markings. These four measured $0.68 \times 0.52 ; 0.68 \times 0.52 ; 0.66 \times$ $0.5 \mathrm{I} ; 0.66 \times 0.5 \mathrm{I}$. The other nest, found June 27 , 
among a tangle of fallen trees, was situated about two feet from the ground on the side of a moss-covered stump, deeply sunken in the soft green moss, which covered it above, though the eggs were visible from the outside. It was a bulky, compact mass of the same moss, with a few bits of arbor vitæ and one or two sticks, thinly lined with grass-stems and rootlets; its outer diameter four aind a quarter, depth four; inner diameter two, depth one and a half. The four nearly fresh eggs were precisely like those just described in ground-color and markings, but ran a trifle larger, the extremes being $0.67 \times 0.5$ I to $0.70 \times 0.54$ (Bull. Nutt. Club, iv, 1879, p. 24I.)

It may be added that a sixth nest, taken by Mr. N. A. Eddy on an island in Penobscot Bay, June I3, I880 was similarly circumstanced, and the eggs were not different from those described above, though ranging a little less in size - not over $0.65 \times 0.5$ I. (Bull. Nutt. Club, v, I880, p. 24I.) 


\section{FAMILY CAPRIMULGID $Æ$. WHIPPOOR- WILLS AND NIGHT-HAWKS.}

WHIPPOORWILL.

\section{Antrostomus vociferus (Wils.) Bp.}

Chars. Mouth cleft to below the eyes, with minute horny part of the bill, and long bristles on each side. Feet very short and weak, unfitted for perching in the usual way. Inner edge of the middle claw dilated and comb-like. Wings little longer than the broad rounded tail; plumage very soft and lax, like an owl's, with blended and varied coloration: prevailing tone gray, variegated with black, white and tawny, in small streaky pattern or delicate marbling; lateral tail feathers tipped with white or tawny; a white or tawny collar on the throat. Length about 9.50; extent, I8.50; wing, 5.50 ; tail, 4.50 ; hind toe short, inserted above the level of the rest, not directly posterior; front toes with movable webbing at base; outer toe with only four joints, instead of five, as usual in birds.

The Whippoorwill, belonging to a family peculiar in many important respects, and of such singular habits and general appearance that superstitions no less dismal than ridiculous have attached to its mysterious manners, is a common summer resident throughout New England, arriving early in May, and becoming dispersed in suitable situations in the course of that month. The bird is nocturnal in habits, and keeps so closely concealed in the day time that it is much oftener heard than seen, as particularly when, the twilight decpening and lengthening shadows merging in the growing gloom, its strange cry rings out with startling effect from no one knows where. 
The bird may be in the brush where it has hidden during the hours of light, or, on pinion as noiseless as that of an owl, it may have stolen close to the house - so close that the queer clicking sound which precedes its lugubrious salute may be distinctly heard. It may even drop unperceived upon the house-top, and cry out with sudden vehemence in the middle of the night, perhaps sending a shiver through those persons whose nervous organization is susceptible of impressions ominous or superstitious. Though wrong conclusions may be corrected by observation and experience - those unanswerable pleaders in the court of nature to which all cases of the kind must be finally referred without possible appeal - it should not

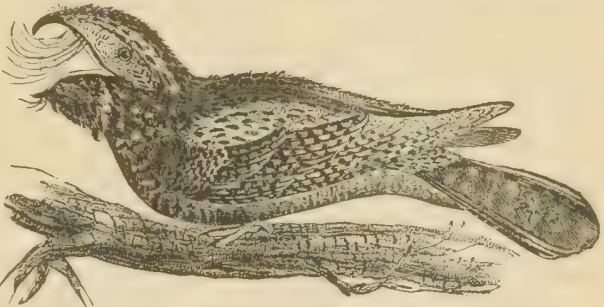

FIG. 4. - WHIPPOORWILL.

lessen our interest in the birds capable of such weird effects; but rather awaken new and more intelligent cognitions of the beauty and harmony which nature's every handiwork displays. No bird is more perfectly adapted to the part sustained in animated nature than the Whippoorwill, and not one can be presumed to more thoroughly enjoy life. It has a number of amiable and admirable traits, among which are its parental affection and devotion, and its conjugal fidelity. Though the young birds hatch covered with down, and thus like chickens or sandpipers, which are able to run about and feed themselves at birth, they are nevertheless as weak and helpless as the naked occupants of a sparrow's nest, requiring assiduous attention on the part of 
the parents. We cannot endorse Mr. Minot's statement that they "run about much like young partridges." Only an apology for a nest is constructed - a slight hollow in the mould of a fallen $\log$ or stump, or on the ground among fallen leaves. The eggs are only two, this being the usual number laid by birds of this family. They are elliptical, and of delicately marbled and clouded coloration, like the plumage of the birds themselves. They measure about $1.25 \times$ 0.85 of an inch, and are usually laid early in June, when the birds are in full cry. The clamor continues during the breeding season proper, after which the cry is seldom if ever heard; and this being the principal indication of the birds' presence, it is difficult to say at what precise time they depart, so silently and furtively do they slip away from our midst. The migration, however, is probably accomplished in September. Like the rest of this family, the Whippoorwill is insectivorous; and numberless are the crepuscular and nocturnal insects which fall into its capacious mouth, as into the wide open jaws of a trap beset with stiff bristles to control the struggles of the bird's unhappy victims.

\section{NIGHT-HAWK OR BULL-BAT.}

\section{Chordediles popetue $(V$. $) B d$.}

Chars. Similar in general to a Whippoorwill; no long bristles about mouth. Wings long and pointed, much exceeding the forked tail; plumage more smooth and compact. Upper parts blackish, mottled with brown, gray and tawny ; under parts from the breast white, barred crosswise with blackish and tawny. Throat with a crescentic bar, white in the male, tawny in the 
female. Tail blackish, marbled with several pale cross-bars, and in the male with large white spaces near the ends of the feathers. Long quills of the wing blackish, with a great white spot on five outer primaries midway between their bases and tips; in the female this mark smaller or not pure white. Length about 9.00 ; extent, 22.00 ; wing, 8.00 ; tail, 5.00 ; bill about 0.25 in its hard part, but with immense gape reaching below the eyes.

This remarkable bird is a common summer resident in New England, arriving early in May, and departing in September. It is confined to no section, but may be observed anywhere in the twilight and also at any time during the day, especially in cloudy weather, coursing with splendid powers of flight overhead like a winged greyhound in endless evolutions. Sometimes it soars till it becomes but a speck to the view, and again skims swiftly low over the ground - now dashing impetuously forward, now sailing with easy bold sweeps of the pointed pinions,

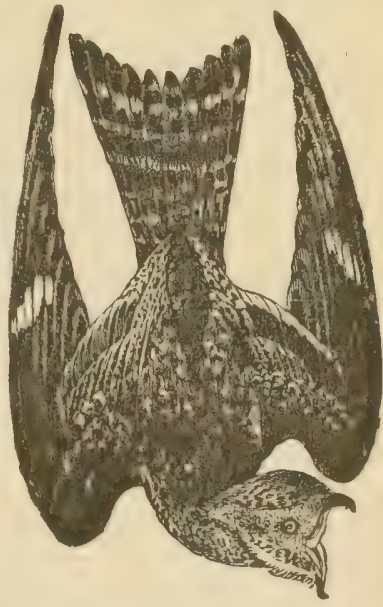

Fig. 5.-NiguT-HAWк. arresting its course for a moment and then twisting and glancing with almost inconceivable velocity in its seemingly random race. But all this while the wayward bird is providently gleaning its food from the air; these forays are made with an eye strictly to business, for the purpose of capturing the tiny gauzy creatures which swim in the rays of the departing sun; and in contemplating such adaptation of perfect grace to utilitarian purposes, we are taught the lesson that nature 
bends the most diverse means to her useful ends. In the spring-time, during the period de noces, the Nighthawk repeatedly plunges head foremost downward with fearful velocity, accompanying this startling tour de force with a strange booming sound, likened by some to the distant bellowing of a bull, by others to the noise made by blowing in the bung-hole of an empty barrel.

About the first of June, the singular incidents of the courtship over, the Night-hawk deposits her two eggs upon the cold bare ground, scarcely a trace of a nest being formed to receive her treasured charge. The eggs are also frequently laid on bare rocks, and even the flat concreted roofs of houses in large cities, where the heat of the sun helps to incubate them, as it does those of terns and sandpipers, while the birds are flying about in broad daylight. The eggs are elliptical in contour, averaging in size $1.25 \times 0.85$, and are curiously fretted, veined and marbled with lavender, stone-gray and neutral tints. She is a faithful and courageous mother, who, when danger threatens, will at risk of life feign to be crippled, and endeavor to divert attention from her eggs to herself by fluttering and tumbling about as long as such pious fraud seems likely to succeed - then quartering anxiously back and forth within a few feet of one who may be bending over the frail orbic bodies that encase her hopes. "The nestlings are hatched downy. This is a singular circumstance, in which the Caprimulgida resemble the lower orders of birds, and not the higher groups with which they are associated. The chicks are not, however, hatched entirely clothed; for the first two or three days they are only densely flocculent on the under parts, the upper being but sparsely downy; soon, however, they 
are uniformly covered with down, variegated above, plain below. The design of this provision is evidently protection from the damp ground on which the young rest. In the several instances of nesting I have found, there was nothing whatever between the birds and the earth; but occasionally, it is said, a few leaves or straws lie underneath them. A favorite nesting-place, in the West, is the little mounds of loose soil thrown up by the gophers, either in open fields, or by the edge of woods. The birds are also said to lay on the mould of stumps and logs, but I have never found eggs in such situations. One of the two eggs may be hatched sooner than the other; in one instance I found an interval of three days to elapse, during which I frequently visited a nesting place. The female, on each occasion, remained near her charge until nearly trodden upon, and then futtered off, making believe she was crippled, as perfectly as I ever saw the pious fraud performed in my life. Not having much, if any, legs to be lame in, she simulated a broken wing, fluttering and pitching about in the grass, at no time more than a few fect off. The statement that the bird will remove her young, if disturbed, is true. The bird I am alluding to carried them to another hillock, after my second visit, but only a couple of yards away."

Late in the summer, when all the birds are on wing, great troops of Night-hawks collect together, and may be seen coursing in the manner above described, crossing and recrossing each other's path in the air, until it becomes too dark to trace their flight any longer. As soon as the gnats and midgets disappear with the cool weather of September, their insatiable pursuers bend strong wings to the southward journey. 


\section{FAMILY CYPSELID $Æ:$ SWIFTS.}

\section{CHIMNEY SWIFT.}

\section{Chetura pelasgica (L.) Steph.}

Chars. General color sooty-brown, with a faint greenish gloss above; grayish-brown below, becoming paler on the throat; wings black. Length, 5.00-5.25; extent, 12.50; wing, 4.75-5.00; tail, 2.00 or less, with spine-like tips of the feathers.

One of the most interesting modifications of birdstructure is that by which the Swifts, belonging to an order of birds entirely different from Swallows in essential points of structure, are moulded to an exterior shape so closely simulating the form of a Swallow, that most persons believe them to be of that kind of bird: and "swallows" they are almost universally called. The resemblance is indeed striking; but it only illustrates how cunningly nature, in some sportive mood, furnishes similitudes in her endless diversity - no less easily than she fashions a wealth of diversity from essential unity. Humor has been defined as a perception of grotesque resemblance between incongruous things, and Swifts are amongst numberless conundrums which nature propounds through her feathered creations. "Why is a Swift like a Swallow ?" I give it up - and I doubt that any one can answer the question.

The most remarkable thing about the exterior conformation of the Swift is the spines which project from the ends of the tail-feathers, and serve as props to stay the bird while clinging with its sharp claws to the verti- 
cal walls of a chimney or hollow tree. In former times, before the country was settled, the birds roosted and builded in hollows of trees, to which they resorted in thousands sometimes - a steady stream of the creatures pouring in at dusk to pass the night. Some such trees have become historic as "swallow-trees," frequented year after year by countless numbers, till the bottom became filled with a mass of dcbris. Now, like Swallows, they have modified their primitive way, and almost always choose to make their nests in chimneys, - whence their name, - though too often exposed in such situations to disaster by fire and flood ; as when a soaking rain loosens the mucilaginous fastening of the nest, and the whole comes tumbling down. The "frying-pan" out of which the little birds sometimes fall "into the fire," is one of the most curious of all speci-
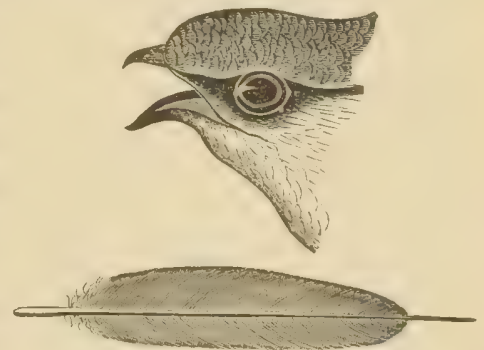

Fig. 6. - CHIMney Swift, with mucronate rectrix.

mens of bird architecture. It consists of a basket-work of bits of twigs, glued together and to the side of the chimney with the sticky saliva of the birds - the same substance that in other cases, as those of the species of the East Indian genus Collocalia, forms the famous "edible bird's-nests" used for making soup by the celestial heathens. The twigs are gathered in the most skilful manner by the birds, who dash past the ends of branches and snap off bits with the beak as quick as thought. The completed basket has a semicircular brim, and shallow cavity, in which are laid four or five pure white, narrowly elliptical eggs, about 0.70 in length by 
0.50 in breadth. In the North woods the nests are still often constructed in hollow trees, as well as in barns and sheds in the sparsely settled districts.

The Swifts reach New England betimes in spring, some seasons by the middle of April, and again not till May, remaining through the greater part of September. Were it not that, being so abundant and so universally distributed, they lack the charm of novelty, they could not but excite wonder and admiration, so splendid are the powers of wing of these sombre-hued little creatures, so graceful and varied are their aerial excursions, so joyous and spontaneous their ceaseless twittering. They have a rare genius for flying, and do well to trust themselves utterly to its promptings - the keen-bladed, sharppointed wing never fails of its stroke, though cutting a substance far more tenuous than the silken fabric which tested the temper of Damascus' steel — not even when a pair, sailing for many rods in close convoy, suddenly meet with "the touch of the body electric," as Whitman says in one of his realistic poems, and as speedily part again, recovering their way with marvellous dexterity. It is a pretty sight, again, to see the Swift hover for a moment over the chimney, then set the wings at an upward angle and drop lightly as a parachute down upon the nest within the smoky orifice. So the summer passes with these most airy of birds, in never ending cycles and epicycles, spirals, scrolls and nameless gyrations round the chosen nesting-place, till the coils are loosened, the circles widen like the waves of a pool disturbed by the falling stone, and the last curve straightens into southward line. 


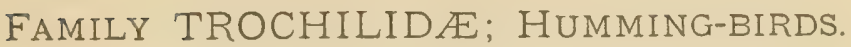

\section{RUBY-THROATED HUMMING-BIRD.}

\section{Trochilus COLUBRIS $L$.}

Chars. Upper parts golden-green; below white, with green sides; a metallic gorget on the throat, reflecting rich ruby-red; wings and tail dusky-purplish, the latter forked, with narrow, pointed feathers. Female similar, lacking the gorget; tail black-barred, with some feathers white-tipped. Length of male, 3.25 ; wing, x.66; tail, I.25; bill 0.66. Female smaller.

These jewelled feathers are so precious that with all the boundless wealth of nature economy must be practised in the use of such materials; which is one reason why the Humming-bird is so diminutive a creature. It is found throughout New England in summer; for, although so delicate in physique that a cobweb may ensnare the tiny creature and even cause its death, the Hummer is full of spirit and fire, and goes well, like a lady's watch, unless some touch too rude should interfere with the movements of so exquisite a mechanism. The adjustment of its vital forces is delicate in the extreme, and so subtile is the play of parts, that even emotion, such as terror, or dismay, or anger, may destroy life; yet, so long as the creature has its freedom to act, and its right to happiness, no braver bird flies. Fancy a Humming-bird attacking a man in defence of its nest! Yet it never hesitates to engage the giant like a very king of Lilliput, buzzing about as mad as a hornet, and making furious if futile thrusts with its rapier-like bill. 
Then again, many and long are the tournaments between rival males inflamed with jealousy and passion, while the little bodies for whom the war is waged amuse themselves demurely with sunbeams and flowers.

Though New England is far from the lands where Trochilida are assembled in endless variety and beauty, the single species which visits us is so common, that it is no remarkable thing to see a perfect galaxy "starring" on some flowery stage, attracted by the sweets which the nectaries of the blossoms distil, the same that make myriads of minute insects flock to a dainty feast. Poised on wings so rapidly whirred that they leave to the eye but a filmy outline, and make the bird seem suspended in the air by invisible spirit-power, the Hummer explores the heart of the flower; now spearing his insect prey with his sharp slender beak; now sucking the sweets through his tubular tongue, curiously fashioned into a sort of syphon. Darting from one flower to another too rapidly for the eye to follow the movements, - and with the humming sound which has given the whole tribe a name, - Colubris repeats the probing process till his hunger is satisfied, and then repairs to some favorite perch, near which probably the nest is placed. This, as many writers have remarked of late with less originality than appreciation, is one of the most beautiful objects in nature. "What enlightened person," incleed, "can gaze upon this nest without regretting that man should in the progress of civilization so often forget Nature, fail to appreciate her, or even wrong her?" The fabric is placed upon a bough large enough for it to rest securely, or in the forking of a twig - oftenest upon some such horizontal support, but sometimes fastened to the side of more upright growths. The cavity only about 
admits the end of one's thumb, but the walls are thick, so that the entire structure is about as large as one of the cups of a child's play "tea-set." The fabric is felted with a mass of exquisitely soft cottony, silky, or woolly substances, such as plant-down and the like, but with very little coarser fibrous material, if any. Outside the finish is simply perfect, being a fresco of lichens. The eggs are never more than two in number; they are pure white in color, with a pink blush when fresh. The shape -is rather elliptical than oval, and the size scarcely half an inch in the long axis by about one-third in the conjugate diameter.

Some may have thoughtlessly believed the characteristic sound emitted by the Humming-bird, from which the name is derived, to be the voice of the bird. But it is never heard when the creature is at rest, and is not vocal, but mechanical, resulting from the rapid vibrations of the wings, like the buzzing of bees and many other insects. The sharp squeaky voice is very different, and not ordinarily emitted; but is uttered with great vehemence and volubility in moments of excitement, as when the nest is threatened, when the courtship grows animated, or when the battle-cry is sounded to a hated rival. 


\section{FAMILY ALCEDINIDÆ: KINGFISHERS.}

\section{BELTED KINGFISHER.}

\section{- Ceryle alcyon (L.) Boic.}

Chars. Head with a long, thin, pointed crest; plumage compact and oily; feet extremely small, with syndactyle toes; tibiæ naked below. Male: upper parts, a broad bar across the breast, and sides under the wings, dull blue with black shaft lines; two spots around eye, and under parts, except breast and sides, white. Female: with a band of chestnut across the lower breast, extending along the sides. In both sexes the quills and tail-feathers black, marked with white on the inner webs; outer webs of secondaries and tail-feathers like the back; wing-coverts usually spotted with white; bill black, pale at base below. Length, I2.00-13.00; extent, 22.00; wing, about 6.00 ; tail, 3.50 ; bill, about 2.00 .

The "King's fisher," who takes his tribute from the streams, be they never so well guarded from ordinary poachers, is a common bird of New England, and resident, or only forced southward by the freezing of the waters upon which his resources depend. But the bird partakes the character of a migrant and summer visitor, as many pairs enter the country in March from the south, and remain until the following November. Being strong of wing, it may be observed at times flying high over terra fima and far away from the liquid element; but its permanent abode is seldom at any distance from its feeding grounds. The mill-pond where the running stream has been dammed to stillness - the running stream that cuts its way through gravelly banks, are 
favorite resorts, almost sure to be tenanted by a pair of these industrious birds, whose vehement cries are not less familar to the miller than the noise of his own machinery. The birds are really far less numerous than many others less conspicuous and familiar, and usually a sheet or stretch of water is fished by only a single pair; but they are large, noisy, assertive creatures, impossible to overlook, and therefore giving an impression of being more abundant than they really are in comparison with less notorious examples of bird-life. They may be seen either swiftly winging along the water-course, or hovering and plunging into the stream to rise successful with a fish in the beak, or perched upon some isolated outpost like aquatic Shrikes. The harsh cry has been aptly likened to the

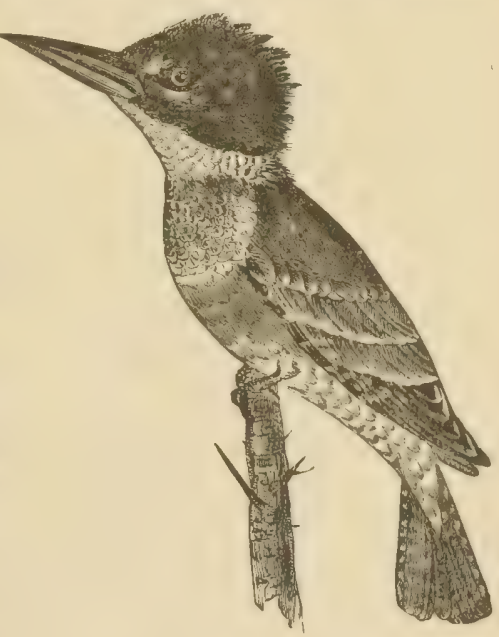

Fig. 7. - KINGFISHER. sound made by springing a watchman's rattle, and it is no less startling in effect when breaking suddenly upon an unexpecting ear.

The Kingfisher is a hole-breeder, like all of its tribe. Some of the many exotic species, which are less aquatic and feed rather upon insects and reptiles than upon fish, nest in hollows of trees; but all the true piscivorous Alcedinide burrow in the ground. A tunnel severalfour, six or eight - feet in length, either straight or 
elbowed, is dug by the bird with its spear-like beak; and in the chambered extremity of this excavation the nest is made, - if a few fish-bones can be called a nest. The sites selected are such as the Bank Swallow chooses; and not seldom a gravel-pit, pepper-boxed with Swallow's holes, shows one larger orifice than the rest, out of which, if one watch long enough, a Kingfisher will be seen to dart with amazing celerity and exultant cry. The eggs are laid late in May and in June. They average seven in number, are pure white (like those of most hole-breeders), and measure about I. $35 \times$ I.00. The Kingfisher nests are usually " handy" to the water, but not necessarily so ; for when no eligible site offers by the margin of the stream or pond, it is a matter of a few moments for the sturdy, sinewy bird to go a mile or more from his fishingwaters and find himself suited. As regards his relations with man, the bird has none that it cares to cultivate; is a thoroughly solitary, self-possessing creature, neither courting nor shunning observation, but simply indifferent; and one who minds his own business so well as to be a perpetual rebuke to the busy-bodies who make so much mischief in the society of featherless "forked radishes." 
C. ERYTHROPHTHALMUS : BLACK-BILLED CUCKOO. 65

\section{FAMILY CUCULID E: CUCKOOS.}

\section{BLACK-BILLED CUCKOO.}

\section{Coccygus erythrophthalmus (Wils.) $B d$.}

Chars. Upper parts uniform satiny olive-green, or "Quaker-color," with bronzy reflections. Below pure white, or with a slight rusty tinge; little if any rufous on wings; lateral tail-feathers not contrasted in color with the middle pair, blackish for a little distance toward the end, then obscurely tipped with whitish; such coloration of the tail-feathers always sufficing to distinguish the species from C. Americanus, without reference to other characters. A bare livid skin around eye; edges of eyelids red; bill blackish with little if any trace of yellow. Length, about I1.50; extent, 15.50; wing, 5.00-5.50; tail, 6.00-6.50; bill, under 1.00 .

Of the two Cuckoos which inhabit New England, the Black-billed is a much more numerous and characteristic bird than its rather southerly cousin of the yellow beak. It is an abundant summer resident in the woodland of all sections, arriving about the middle of May, and remaining through September. But somewhat like $C$. americanus, it is toward the end of its migratory tether in New England, and therefore less common in the Canadian than in the other two Fauna represented in New England. Excepting for its hard dry voice, sounding so strangely that, however often heard, one scarcely becomes accustomed to the wild outcry, it would not be very frequently noticed, with so sly and furtive a manner does it wing its swift arrowy course through the foliage, or study concealment in the umbrage. Its habits 
are specially secretive during the nesting season, when it has much of the sneaking, skulking ways of the parasitic Cuckoos of the old world, which have set a stigma upon the family name. At other seasons it is more likely to come under observation, when its lithe form enlarges by the spreading of wings and tail as the agile creature turns and twists in active pursuit of its prey. Nor is there any reason why the Cuckoo should hide its head; it is an orderly member of a disreputable family, rarely practising the vice which disgraces so many of its relatives, only lapsing occasionally into what the Evolutionists call "atavism," when it drops an egg in some other bird's nest by sheer force of hereditary habit. The Cuckoo might reasonably apologize for such misdemeanor by urging a weight of family cares which few birds have to bear; being unable, through some defect of its eggingapparatus, to lay in rapid succession, and so incubate and raise a brood at one effort. The eggs follow at such long intervals, that some hatch before the rest are dropped; and what with gaping throats to be satisfied, eggs to be covered and more to come, the birds have a hard time of it. The wonder is not that they are sometimes remiss or amiss in their cluties, but that they do not seek a watery grave in the nearest Kingfisher's premises.

The nest will usually be found in a low tree or bush, sometimes even on a briar patch close to the ground. It is a slight loose structure of twigs, often a mere platform, but sometimes better finished with leaves, catkins and bark-strips. The eggs are numerous, as already hinted, but it is not easy to say exactly how many; probably seldom over five. They are elliptical in shape, greenish in color, of the tint prevailing in the eggs of our herons, and measure about I. $5 \times 0.90$. 


\section{YELLOW-BILLED CUCKOO.}

\section{Coccygus americanus (L.) Bd.}

Chars. Upper parts as in foregoing species; under parts milkwhite; middle tail-feathers like the back in color, the rest black, with large white tips; wings extensively rufous; under mandible and edge of upper mandible yellow. Size of the last, or slightly larger.

The traits and habits of the Yellow-billed Cuckoo are those of the species just described, but the bird is much less numerous in New England, and decidedly more southern. It really belongs to the Carolinian Fauna, though over. lapping the next one, and even appearing at times in the

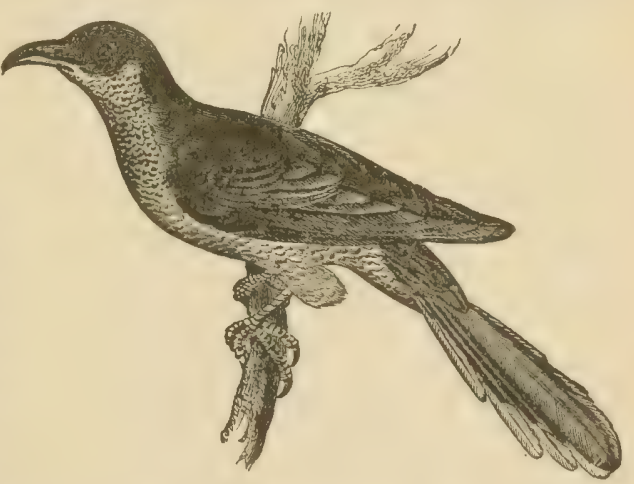
Fig. S. - Yellow-billed Cuckoo.

Canadian. It is rather more of a woodland bird, keeping more in higher forests, and usually nesting at a greater altitude. Out of the immediate valley of the Connecticut it is somewhat irregular in its appearance, quite common some years in particular localities, and again hardly to be found. Mr. Merriam calls it a common summer resident in Connecticut. Mr. Minot says that it has evidently become less numerous near Boston than it once was, and is now considered rare in many if not all parts of New England. Mr. Allen speaks 
of it as a rather frequent summer resident of Massachusetts, somewhat irregularly dispersed, and very variable in respect to numbers in different years. At Amherst, where I have found it breeding, it is more or less numerous every year. According to Mr. Brewster it was not seen by him at Upton, Franconia or Gorham, and was rare at Norway, in Maine.

The nests and eggs cannot always be distinguished from those of the Black-billed Cuckoo, with that certainty requisite for the value of oological material; the eggs are, however, on an average more oval, larger and paler greenish. The same irregularity and delay in oviposition that we have noted in the case of the Blackbilled is witnessed in the present instance, it being the rule to find in the nest eggs in various stages of incubation, with or without young birds also; and this species shows the same lingering tendency to drop eggs in alien nests. It has recently been established that the Ground Cuckoo of the Southwest, Geococcyx californianus, has the same habit; and various irregularities of the kind are probably more prevalent among American Cuckoos than many are aware. The species of Crotoplaaga, for example, offer the curious case, that a flock clubs together to build an enormous nest, in which several individuals lay their eggs and hatch their young in a singular sort of communism. Thus it appears that our Cowbirds (Molothus) are far from being alone among American birds in undesirable domestic traits. 


\section{FAMILY PICIDA: WOODPECKERS.}

\section{PILEATED WOODPECKER.}

\section{Hylotomus pileatus (L.) $B d$.}

Chars. General color black; head, neck and wings variegated with white or pale yellowish; bill dark horn color. Male, with a scarlet crest, and scarlet cheek-patches. Female, with crest only half scarlet, and no cheek-patches. Length, from 15.00 to I 9.00 ; extent, about 28.00 ; wing, 8.50-9.50; tail, 6.00-7.00.

Another of the many chapters for which the nonoscine and non-passerine land birds of New England furnish us occasion opens with the largest and finest representative of the Woodpecker family, many members of which will be seen to enter into the composition of our feathered fauna. The Pileated Woodpecker, or Logcock, or Black Woodcock, as the bird is called sometimes, is a species of wide and general distribution in North America; but a wild and solitary bird, delighting in the recesses of forests deepest and hoarest with age. It is one which retreats instinctively at the crack of the axe and the shriek of steam, and is therefore almost exterminated in the cleared and settled portions of New England. Some years hereafter, the faithful compiler of the records will present interesting items of the occurrence of this "rare species" here and there; but for the present it may be spoken of in more general terms, as all of the "forest primeval" still harbors the great, black, scarlet-crested woodman, chips of whose powerful chiselling are still scattered at the feet of many a decrepit monarch. In 
the nature of the case as stated, the Pileated Woodpecker is more numerous in northern than in southern New England, not in the least as a matter of geographical distribution, but simply because the heavy-timbered, swampy backwoods are best suited to its nature. Wherever the bird makes its abode, its presence is likely to be indicated by the noise of its hammering, audible at much greater distances than the tapping of the weaker Woodpeckers can be heard. It is also capable of much

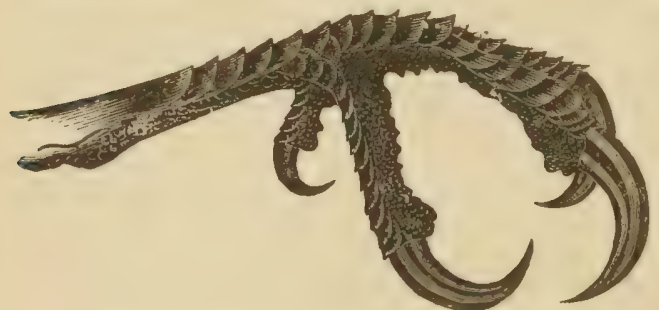

Fig. 9. - Foot of Pileated Woodpecker. more extensive operations in denuding trees of their bark, often laying them bare in great areas. In thickly wooded swamp land, it may sometimes be seen working upon fallen $\operatorname{logs}$; but it generally keeps high up among the tree-tops, especially such as are blasted by lightning or began their natural decay by "dying at the head." From such elevated posts of observation it surveys a wide ground; watchful of every suspicious movement, and wary to the last degree, it makes off at the first alarm, and easily escapes pursuit.

The eggs of all the Woodpeckers are of a crystalline texture, rounded form, and pure white color. They cannot be distinguished from each other, not even by size. For instance, the egg of the Pileated is remarkably small in comparison with the linear dimensions of the bird; showing that the result depends largely upon the configuration of the parent. The eggs average about $1.25 \times$ I.OO, being thus not greatly larger than Flicker eggs. 


\section{HAIRY WOODPECKER.}

\section{Picus villosus $L$.}

Chars. Back black, with a long white stripe; quills and wingcoverts black, profusely spotted with white; four middle tailfeathers black; next pair black and white; next two pairs white; Under parts white; crown and side of head black, with a white stripe above and below the eye. Male with a scarlet band on nape, which is wanting in the female; in young birds the crown is mostly red or bronzy. Varies greatly in size. Length, usually 9.00-9.50; extent, $16.00-17.00$; wing, about 5.00 ; tail, 3.00 ; bill, I.00; tarsus, middle toe and claw, 1.66.

A resident bird throughout New England in wooded regions, but not so abundant as its "little brother," the

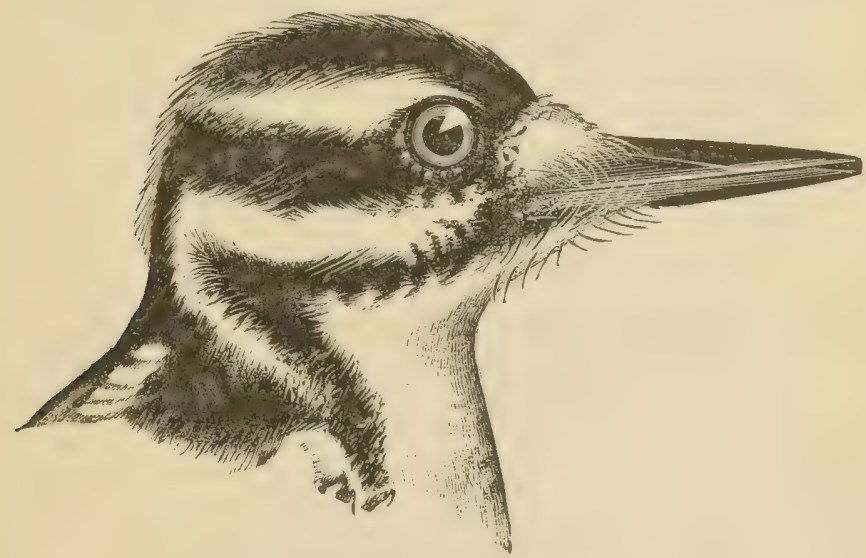

Fig. 10. - Hairy Woodpecker.

Downy Woodpecker. There may be some shifting of locality with season, though hardly a migration in the strict sense of the term: for most observers agree that the Hairy is more numerous in the winter than in sum- 
mer, at any rate in southern New England. Such relative numbers may perhaps be accounted for by the fact that it is a rather shy and solitary bird, especially during the breeding season, - one which resorts to secluded places to nest, and is therefore less likely to come under observation. The clearing away of the forests affects this bird as it does the Pileated, though to less extent, as the Hairy will often visit orchards, gardens and parks, to which the greater bird is a total stranger. The nesting is in no wise peculiar; the eggs are four to six in number, measuring about $0.85 \times 0.65$, laid in May and sometimes early in June. The young birds differ from the adults in having the top of the head bronzy red or even yellow, but may always be recognized by the characters given above, being much larger than the Downy Woodpecker, which they so much resemble in coloration.

\section{DOWNY WOODPECKER.}

\section{Picus pubescens $L$.}

Chars. Coloration exactly as in P. villosus, excepting that all the lateral tail-feathers are barred with black and white. Size much less. Length, 6.00-7.00 ; extent, I1.00-12.00 ; wing, 3.50 ; tail, less than 3.00 ; bill, about 0.66 ; whole foot, 1.25.

The numberless holes you have so often seen drilled with regularity in rows around the trunk and large branches of the apple-tree are the work of this industrious and indefatigable little bird, whose tappings you may often have heard, or whose speckled body has so often put the tree-trunk in your line of vision when you sought to watch the hammering and chiselling process. 
The holes do not injure the tree, and the active carpintcro is one of the best friends of the fruit-grower, by destroying the insidious creatures which lurk beneath the bark and work destruction of his hopes in the end, unless their mischief is stayed by the friendly bird. Few of our feathered friends, indeed, are more directly beneficial to the husbandman than Woodpeckers, whose natural food is the eggs and larvæ of insects that prey upon the living objects of his concern; and among them all the Downy holds a leading place, through its great abundance, its familiarity and its industry. 'Its work of boring into the bark, particularly of the dryer, older and more grub-infested trees must not be mistaken for the barkstripping operations of the Splyyropicus, of which more anon, though both are too often confounded

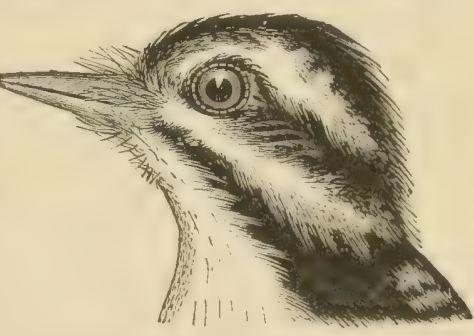

FIG. 11.-DOWNI WOODPECKER. by the careless observer under whose ban they come together with the name of "sapsuckers." Open the mouth of one of these borers whose work is beneficial, seize the tongue, and you may draw that curious organ far out beyond the end of the beak : it is a slender, cylindrical, sinewy spear, of a delicate flesh-color, arrow-headed and barbed. By a wonderful muscular mechanism the bird poises the quivering weapon and launches it forth with unerring aim to secure the hapless grub, which is then as adroitly withdrawn all writhing into the captor's horny beak. The tongue of a Yellow-bellied Woodpecker is so constructed as to be scarcely extensible, and therefore fails of any such office as I have described. 
Like the Hairy Woodpecker, the Downy is rather more frequently observed in fall and winter than in the breeding season; it is often prompted to seek safety in seclusion, but with the fearlessness of innocence, and that confidence in humanity which one's own clear conscience so often establishes, to be so often abused, it not seldom nests in the orchard and garden. With almost incredible labor do the hopeful and expectant pair chisel a hole for the nest, relieving and cheering each other until the excavation, to them more important than the exhumation of a buried Ilium, is completed to their satisfaction; when, about the middle of May, upon the bare chips and mould at the bottom of the cavity, the mother bird finds her crystal spheres, to the number of five or six, in size about three-fourths by three-fifths of an inch.

\section{BLACK-BACKED THREE-TOED WOOD- PECKER.}

\section{Picoides arcticus $(S w$ ) $G r$.}

Chars. Only three toes; back uniform black; under parts white, barred on sides with black; sides of head striped with black and white; quills spotted with white; middle tail-feathers black, lateral white, none barred. Crown of male with a square yellow patch. Length, 8.00-9.00; wing, 4.50-5.00 ; tail, 3.50-4.00.

The whole range of ornithological science furnishes scarcely another instance than the genus Picoides of the reduction of the digits of a bird to three, of which only two point forward, and of which the hind one is really the outer toe reversed to take the place of a missing hallux; for in the three-toed genera of Alcedinide (Alcyone 
and $(\cos x)$, for example, one of the anterior toes is aborted, and the proper hind toe remains in place. In one of the genera of Picumnida, however, there are likewise only three toes. How the peculiarity originated, or what useful purpose in the bird's economy is subserved by this unique anomaly, we are ignorant. It may be gravely doubted that a special creative fiat was required to remove the inner hind toe of a Woodpecker; and more reasonably presumed that supreme intelligence was equal to the establishment of laws by the orderly operation of which the modification in question was from the beginning a foregone necessity. However this may be, the loss of a digit does not appreciably interfere with the bird's pursuit of happiness, nor affect in any marked degree its methods of attaining that end, which are the same as those employed by all its four-toed relations.

As implied in the name, the Black-backed Woodpecker is a boreal bird, finding the limit of its breeding range, as well as of its permanent abode, in the forests of northern New England, in the Canadian Fauna, and being for the rest only a winter visitor, of more or less rarity according to the weather or other extrinsic conditions of its movements. In Connecticut, according to Mr. Merriam, it is a rare winter visitor (B. Conn., I877, p. 64). The Massachusetts records are more numerous: for instance, see Allen, Pr. Essex Inst., iv, I 864, p. 52; Coules, ibid., v, I868, p. 262 ; Allen, Am. Nat., iii, I870, p. 572 ; Purdie, ibid., vii, I873, p. 693; Allen, Bull. Essex Inst., x, r878, p. 20 ; Deane, Bull. Nutt. Club, v, I880, p. 56 ; Brewster, ibid., vi, I 88 I, p. I 82.

The general habits and mode of nesting are in no wise peculiar. The eggs measure about $1.00 \times 0.80$. 


\section{WHITE-BACKED THREE-TOED WOOD- PECKER.}

\section{Picoides americanus Brehm.}

Chars. With only three toes like the last, and quite the same coloration, excepting a white lengthwise stripe down the back, which is interrupted by black bars. Size of the last.

This is a second species of the mutilate Woodpeckers - one whose range is intrinsically the same as that of its amputated congener, but whose winter wandering, as far as known, is not as extensive as the Black-back's. There is no record for the Carolinian Fauna that I am aware of, and there are very few for the Alleghanian, though the bird is now and then seen in Massachusetts as a winter visitor from the north. Even in the forests where it resides it is a rarer bird than $P$. arcticus. The principal authority for its occurrence in Massachusetts is Mr. Allen, who mentions a pair taken near Lynn by Mr. George O. Welch (Am. Nat., iii, I870, p. 572).

\section{YELLOW-BELLIED WOODPECKER.}

\section{Sphyropicus varius $(L$. $) B d$.}

Chars. Male: crown crimson enclosed in black; chin, throat and breast black, enclosing a crimson patch on the former (which is white in the female); sicles of head with two white stripes, one curving from the eye around the nape, the other running from the bill down the side of the neck, these stripes separated by black, and sometimes decidedly yellowish, instead of white; belly yellowish ; sides with dusky arrow-heads; back variegated with black and yellowish; wings black, the quills profusely spotted 
with white, the coverts with a large oblique white bar; tail black, most of the feathers edged with white, and the upper coverts mostly white. "Young birds lack the black areas of the head and breast, and the crimson throat patch, these parts being mottled gray. But in any plumage the bird is recognized by its yellozuness, different from what is seen in any other eastern species, and a broad white wing-bar." The tongue is scarcely extensible. Length, about 8.50 ; extent, $15.00-15.50$; wing, $4.50-$ 5.00 ; tail, 3.50. A slight variety (nuchalis), with a band of red . on the nape in addition to that above described, is sometimes seen in New England.

This is a very different kind of Woodpecker from any of the foregoing - one remarkable not only for the varied beauty of its coloration, but also for certain anatomical peculiarities in which it stands alone among all the New England species, and as the cause or result of which, it is unlike the rest in its vital economy. The tongue cannot be thrust far out of the mouth, nor is it fashioned like a spear, being brushy at the end with little of the acuteness and hardness seen in the same organ of other Woodpeckers. It feeds upon insects, but only derives a portion of its sustenance from such sources, and takes the winged imagos readily by pursuing them in the air and returning after such exploits to its perch, almost in the manner of a Kingbird or Pewee. Nuts, berries and other fruits vary its fare; and to procure these it may often be seen creeping and hanging in the strangest attitudes among the terminal twigs of trees, so slender that they bend with the weight of the bird. The traces of its carpenter work on trees are quite peculiar; for it has a way of operating on sound healthy wood when the sap is flowing, by which patches of bark some inches in diameter are removed. The object of the bird is apparently to get at the soft succulent inner 
bark in which the circulation of the wood is most active, and we cannot suppose that trees girdled and bled in such fashion are not injured by the operation. To some extent therefore the bird merits the name of "Sapsucker," and deserves the disfavor with which its appearance in the orchard is usually regarded.

Woodpeckers as a rule are stationary or nearly so,

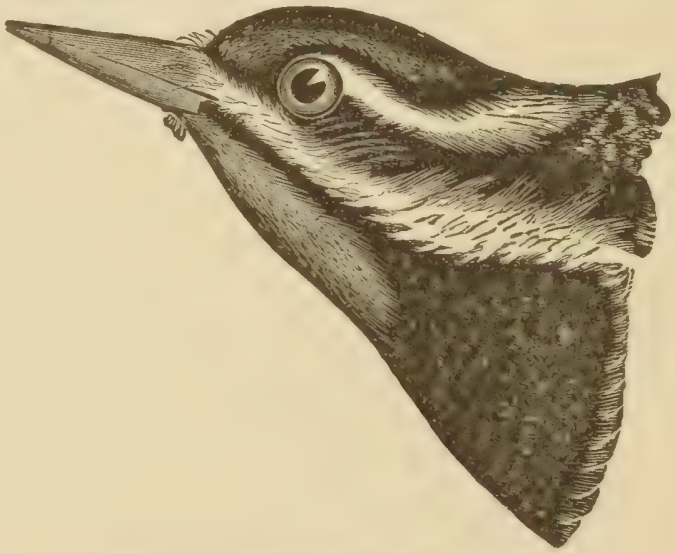

Fig. 12. - YelLow.BELLied WoOdPEcker.

shifting their quarters rather according to fortuitous circumstances than in obedience to the strict law of northsouth migratory impulse. If any one of our species comes fully within the letter of the law, it is the Yellowbellied, as indeed might be inferred from what has been said of the nature of its food. In southern New England, the bird is chiefly observed in spring and fall; in other sections it is a common summer resident, breeding in large numbers. No one should be surprised to hear of the bird in mid-winter, though I have overlooked the records to this effect, if any, indeed, exist. The mode of nesting is in no wise pecul- 
iar, nor are the eggs to be recognized by any infallible characters. They are four to six in number, and measure about $0.90 \times 0.75$, but vary much in size as well as in degree of sphericity.

\section{RED-BELLIED WOODPECKER.}

\section{Centurus carolinus (L.) Bp.}

Chars. Upper parts closely banded crosswise with black and white ; under parts whitish, reddening on the belly, with black arrowheads on flanks; tail black, thəouter feathers barred with white, the central feathers with black and white spaces; rump mostly white; primaries with large white blotches near the base, and other smaller spots. Male with the whole crown and nape scarlet. Female with less of this color. Length, 9.50-10.00; extent, 16.50-17.50; wing, about 5.00; tail, about 3.50 .

The Red-bellied is the rarest of all the New England Woodpeckers, being in fact only a casual summer visitor to the limit of the Carolinian Fauna, or slightly beyond. There is at least one early record of its occurrence in Connecticut, being that given by Linsley in I843 (Am. Journ. Sci., xliv, p. 263); and other instances of like nature have latterly been added by Mr. Merriam (Hartford and Suffield ; B. Conn., I877, p. 65). Prof. Emmons gave it as breeding in western Massachusetts many years ago, and Mr. Allen has recently witnessed its occurrence in May at Springfield (Pr. Essex Inst., iv, I 864, p. 53 ; Bull. Essex Inst., x, I878, p. 20. See also Plummer, Bull. Nutt. Club, vi, I88I, p. I 20 ; Brewster and Allen, ibid., p. I83). It has been said to breed regularly though rarely in Long Island, and has often been seen in New York and Canada West. 


\section{RED-HEADED WOODPECKER.}

\section{Melanerpes erythrocephalus ( $L$.) Sw.}

Chars. Glossy blue-black; whole head, neck, and forebreast crimson; under parts from the breast, rump, and secondaries pure white; primaries and tail feathers black. Sexes alike: Young, with the head plain gray, and the white secondaries barred with black. Length, 9.00-9.50 ; extent, 16.50-17.50 ; wing, 5.255.50 ; tail, 3.50 .

The "red, white and blue" of this brilliant bird makes by far the most artistic display of color-contrast to be seen in the green woods of our country - not even the Scarlet Tanager or the Rose-breasted Grosbeak can compare with such flashing hues. Besides being arrayed in the handsomest of attire, this Woodpecker is inexhaustible in fertility of inventions for pleasure or profit, and so versatile in the exhibition of resources for those ends as to partake of the character of genius. Its habits are therefore not easy to describe in a few words - its traits cannot be labelled in conventional phrase, and filed away with those of other woodpeckers - they require a pigeon-hole of their own, which might be filled with anecdotes illustrating what has been said, did not the limits of our work forbid us that indulgence.

The appearance of the bird in New England is irregular, like most of its habits. Comparisons of the older with most recent authorities on the subject indicate that the species is now much less numerous than formerly. This can hardly be owing to the progress of civilization, for the bird is as much at home in the garden and park as in the depths of the woods. The 
persecution which so conspicuous an apparition invites may have something to do with decreasing the numbers of the species; for certainly all persons with gun in hand, on their collecting tours, cannot resist the temptation of a shot at the beautiful creature, and the bird itself is one which never seems to profit by the lesson of danger notoriety teaches. It really belongs to more southern and western regions, its numbers in summer being greater in the Middle and even the Southern States than they are in New England; and though it has been seen in each of our six States, it does not ordinarily proceed beyond Massachusetts. It was formerly not uncommon around Amherst, where I found several pairs nesting, and heard of others, and Mr. Purdie narrates that of late years numbers have occurred in Eastern Massachusetts (Bull. Nutt. Club, vii, I882, p. 57). Even in Connecticut it is not so numerous that Mr. Merriam did not consider it worth while to specify various instances of its observation or capture in that State, where there appear to have happened various irruptions of the bird in considerable numbers, but at irregular intervals. Notwithstanding such scarcity on the confines of its distribution, and in spite of the fact that this species is one of the most decidedly migratory members of its tribe, it has been found within our limits in winter, on more than one occasion - as, for instance, about Boston during December, January and February. It cannot be considered exclusively a visitor from the South, knowing, as we now do, its range in New York State, as recently indicated by Dr. Merriam (Bull. Nutt. Club, vii, 1882, pp. 57, 63).

Wherever occurring at all in summer, it is not likely to be found alone, but in pairs, and often in companies; 
and its breeding in New England is one of the most orderly events of its desultory existence. The mode of nesting is not peculiar, a hole being excavated by the joint labor of the pair, generally in decayed wood so soft as to be readily chiselled out. A favorite situation is the blasted top of a tree, at a considerable elevation; but its choice wavers with its whim, like all the rest of its actions, and it will often nest in a stub or even a fence-post. The eggs are usually four, five, or six in number, of characteristic whiteness and smoothness, measuring about 1.00 by 0.80 , but too variable in this respect to be identified either by size or shape. The diet of the bird is by no means confined to grubs dug out of the bark; it catches insects on the wing with some address; and is fond of acorns, beech-nuts, and other small fruits, hard or soft, often laying the products of the orchard and garden under contribution by way of variety.

\section{GOLDEN-WINGED WOODPECKER; FLICKER.}

\section{Colaptes auratus (L.) Sw.}

Chars. Back, wing-coverts and inner quills olive-brown, closely barred with black: quills and tail-feathers black, with goldenyellow shafts and under surfaces. Rump, snowy white; crown and nape, ash, with a scarlet band; chin and throat, lilacbrown; a large black shield on the breast; under parts with numberless circular black spots; tinged on the belly with yellow, on the sides with creamy-brown. Male, with black maxillary patches, wanting in the female. Length, 12.00-13.00; extent, 18.00-20.00; wing, 5.75-6.25; tail, 4.50.

Last but not least of its interesting tribe comes this beautiful Woodpecker, so well known in New England 
as to have received half a dozen popular names besides those by which it is usually designated, as above. It is a resident, but less common in winter than at other times, as scarcity of food or other causes sends most individuals southward during the most inclement part of the year. It is a bird of wood-land, and nests after the manner of others of its family by excavating a hole in trees: but it is far from being confined to the depths of the forests, displaying its gilded plumes and eminent musical inability in parks, orchards, and even in fields, and by the wayside remote from forests. Its slightly curved bill is less sharp and chisel-like than most woodpeckers', and its boring for insects in wood is less habitual. Much of its food consists of fruits, and it is particularly fond of ants. To procure these insects it

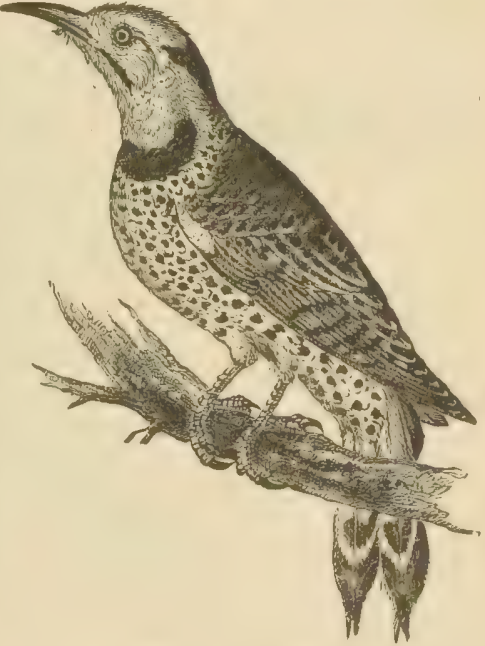

Frg. 13. - Flicker. visits their hills, and finds no difficulty in capturing them by means of its very extensible, lumbriciform tongue, covered with tenacious saliva, and capable of being thrust out several inches beyond the point of the beak. Its body sometimes acquires a smell of formic acid from such diet. This is one reason why the Flicker is so often seen away from trees, and foraging on the ground. Even when in the woods, it is often observed perched upon a bough in the fashion of ordinary birds, rather than 
clinging to the upright trunks. Although so numerous and ubiquitous, the Flicker is a shy and watchful bird, easily alarmed by any unwonted approach, and quick to change its base of operations when disturbed, unless it has already made its nest.

In this labor, shared by the two sexes with equal assiduity, the birds are untiring until the hole is exca-

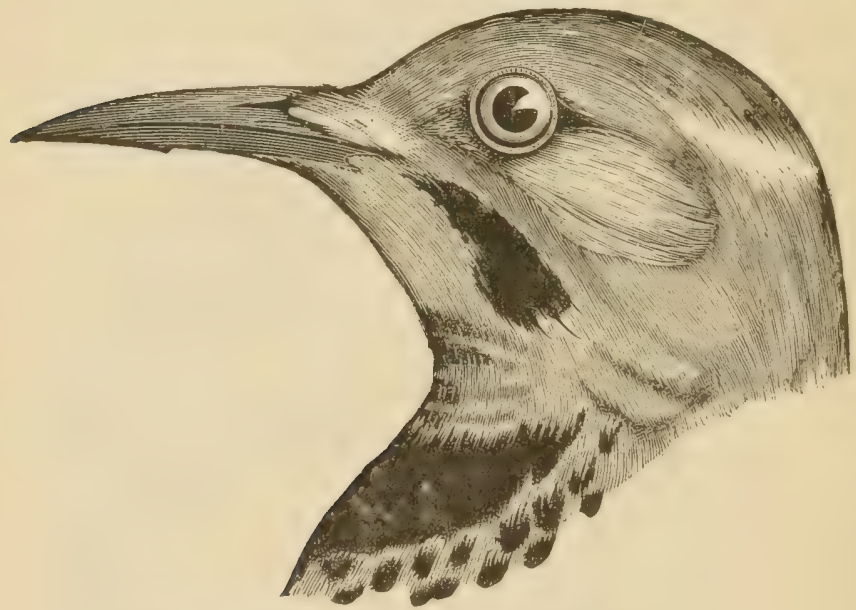

Fig. 14. - Head of Colaptes auratus, Natural size.

vated to the proper depth, and repeated annoyances seldom suffice to drive the devoted pair from their chosen abode. If the nest is robbed, the female will bravely go on laying eggs - in some instances to the number of nearly two dozen before her resources are exhausted. If undisturbed, the usual number of eggs is six or seven, in shape not so nearly spheroidal as those of more typical Woodpeckers. They measure on an average about I. I 5 in length by 0.90 in breadth, but are very variable in size and shape. As soon as the 
young are strong enough to use their feet, they scramble to the entrance of the burrow, and may soon after be seen clinging to the bark near the nest, while the anxious, but delighted parents, proud of their promising beauties, encourage them to take short flights, till by degrees they become confident on the wing, and able to take care of themselves. Such duties and pleasures over, the birds display more strongly than in spring their sociable and almost gregarious nature, being generally seen trooping in considerable numbers until late in the fall, when all but the most hardy individuals make their way southward. 


\section{FAMILY STRIGID尼: OWLS.}

\section{BARN OWL.}

\section{Aluco flammeus pratincola ( $B p$.) Coues.}

Chars. Facial disc highly developed. No tufts on head. External ear very large, operculate. Plumage very downy. Colors above, tawny, clouded with ashy and whitish, speckled with blackish. Below, varying from whitish to fulvous, with sparse, sharp blackish spots; face white or fulvous, dark about the eyes, and bordered with dark brown. Wings and tail barred with brown, and mottled like the back. Feet bristly, but not densely feathered. Length, I6.00-17.00; wing, 12.00-13.00; tail, 5.50; bill whitish; toes yellowish.

Of the thirteen species of Owls found in New Eng-

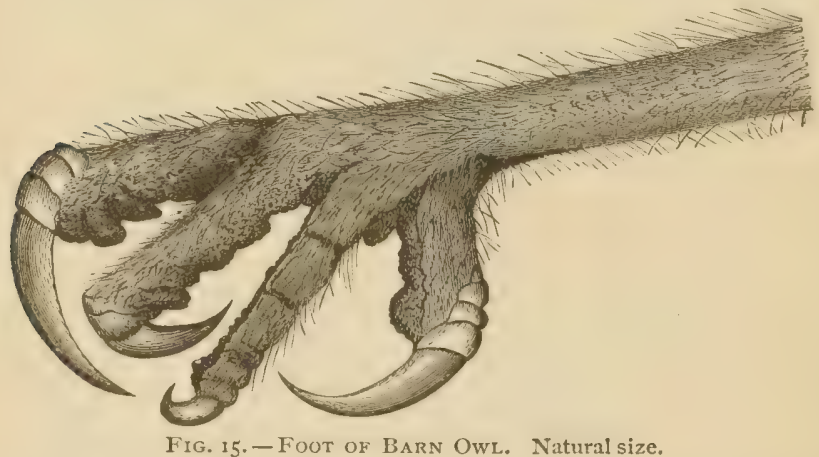

land, the present is the rarest, excepting the Burrowing Owl, which only occurs accidentally. The Barn Owl is little more than a straggler to southern New England; and the recorded instances of its occurrence are very few. Many years ago, a specimen was taken by the 
Rev. J. H. Linsley at Stratford, Conn. (Am. Jour. Sci,, xliv, I843, p. 253). According to Mr. Merriam, one was found by Dr. Wm. O. Ayres at Hartford, Conn., about the year I84I ; and another was killed at Madison, Conn., some years ago (B. Conn., I877, p. 67). The fourth record for the State is given by Mr. J. A. Allen, who states that Dr. William Wood has a specimen in his cabinet shot at Sachem's Head, Conn., Oct. 28, r 865 (Am. Nat., iii, I870, p. 570). There are two Massachusetts records : the first, given by Dr. Coues on Mr. Allen's authority, of a specimen killed near Springfield, in May, I868 (Pr. Essex Inst., v, I868, p. 312); the other of one shot in Lynn, about i864, as given by Mr. Allen (Am. Nat., iii, r870, p. 646). The alleged Maine instance (Brown, Bull. Nutt. Club), ii, I877, p. 28) has proven erroneous. See Brown, Bull. Nutt. Club, vii, 1882, p. 58.

\section{GREAT HORNED OWL.}

Bubo virginianus (Gm.) Bp.

Chars. Of great size, with conspicuous ear-tufts, and facial disc complete ; feet entirely feathered. Length about 2 feet; extent, 4 feet; wing, 16.00 inches; tail, 10.00. Plumage intimately varied with blackish, whitish, light and dark brown, and tawny: a white collar on the throat. The sexes are alike, but the female is larger than the male.

This large and powerful Owl, yielding only to the Great Gray Owl in size, and to none of its tribe in spirit and vigor, is a resident bird throughout New England, and one of the commonest of the nocturnal birds of prey. It chiefly inhabits the forests, but not seldom is 
its dismal hooting heard from some tree about the farm-house in places where the woods have been cleared away; while its occasional raids upon the poultry yard are only too well known. No nest is usually constructed: the eggs are laid in the hollow of a tree, or in the cleft of rocks, often in the deserted nest of a hawk,

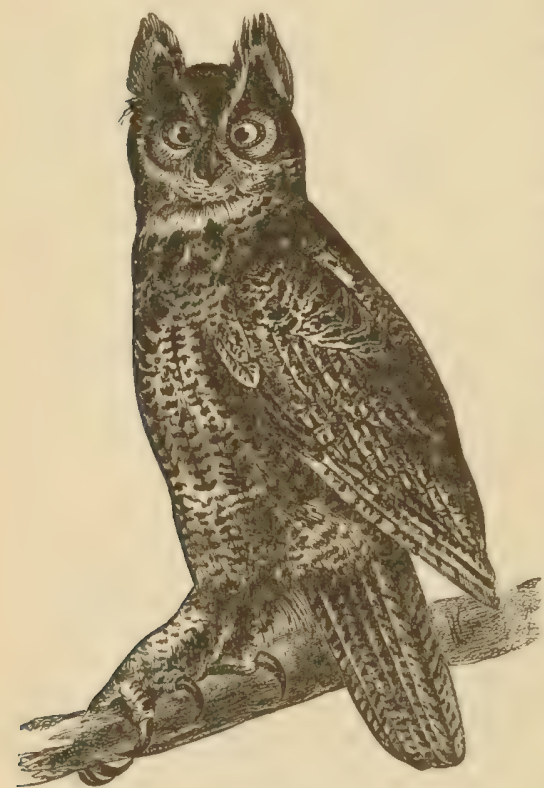

Fig. 16. - GREAT Horned OwL. which is patched up to suit, and very early in the season - in February or March, seldom if ever later than April. Statements of authors are greatly at variance respecting the nidification, as well as the number of eggs. So widely distributed a bird doubtless changes its habits to some extent according to circumstances; but in New England, at any rate, the rule is that no nest is built, and only two eggs are laid. The probability is, also, that the eggs produce a male and female, as usual among pigeons. They are white in color, and measure about 2.25 by I.9o. These fine large Owls are sometimes taken alive in traps, and may easily be reared from the nest; they stand confinement well, and make interesting pets for those who are fond of studying the traits of rapacious birds in captivity. 


\section{SCREECH OWL: RED OR MOTTLED OWL.}

\section{Scops asio (L.) Bp.}

Chars. A miniature bubo in form, with equally conspicuous eartufts, feathered legs and bristly toes. The plumage differs so remarkably (and not according to age, sex, or season), that the "red," and "gray" or "mottled" Owl were long supposed to be two distinct species. In the gray plumage, the bird is gray, paler or whitish below, speckled with blackish above, and below blotched with the same. In the other condition, the general tone is bright brownish-red above, with sharp black streaks; below, whitish or fulvous, much variegated. In either state, the wings and tail are barred with light and dark colors. Length, 8.00I0.00 inches; extent, about 20.00; wing, 6.50-7.00; tail, $3.00-3.50$.

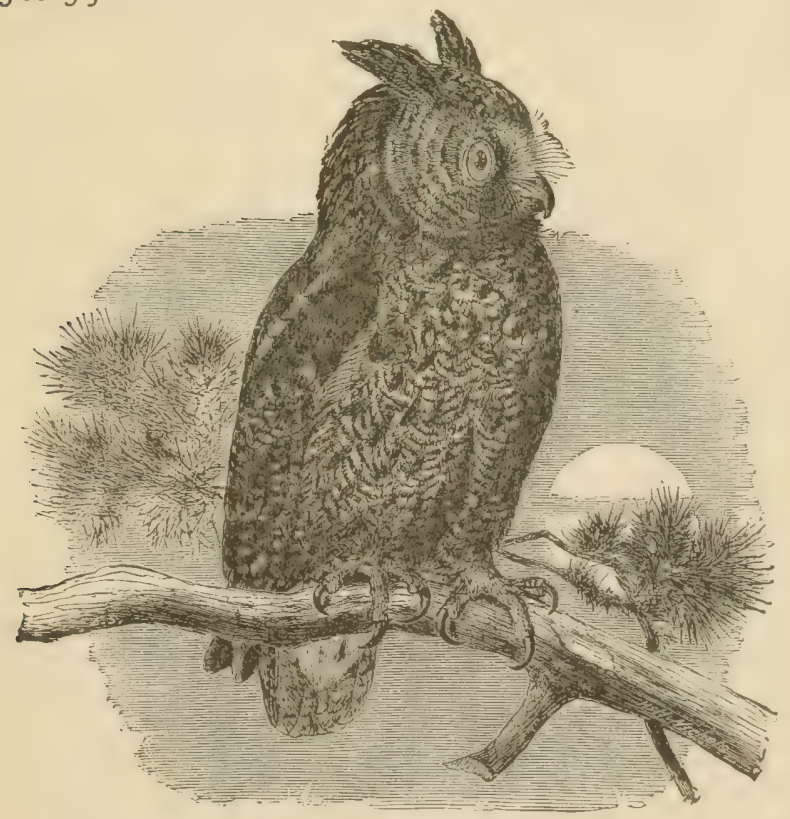

FIG. 17. - SCREeCH OWL. 
A very common New England species, like the last, but strictly nocturnal, seeming dazed by the light whenever it is forced to fly from the dark nooks where it loves to pass the day. The Great Horned Owl, on the other hand, flies well by day, seeming little incommoded in the sunshine. The nest of this little species is in a hollow tree, with sticks, leaves or feathers to receive the eggs: these are four to six in number, measuring about 1.40 by 1.25, and are laid usually in April. The bird is one of those that comes the most familiarly about houses, sometimes even taking up its residence in an outbuilding. Its tremulous, screeching notes, very different from the deep-mouthed hooting of the larger Owls, are familiar to all who have any experience with rural sounds. Like other Owls, the whole tribe of which are more notable in such respect than the diurnal birds of prey, the present species is very beneficial to the farmer by destroying field-mice. It is indeed to be regretted that the good offices of Owls are not more fully recognized. Though "the mousing Owl" is proverbial, few appear to have learned the full truth of the expression.

\section{LONG-EARED OWL.}

\section{Asio wilsonianus (Less.) Coues.}

Chars. A medium-sized species, with conspicuous ear-tufts, facial disc complete, immense external ears, and feathered feet. Plumage above intimately variegated with dark brown, fulvous, and whitish; breast more fulvous, sharply striped; belly whiter, striped and barred with blackish; wings and tail mottled, and closely barred with fulvous and dark brown. Face pale tawny, with black spots and eye-patches; bill and claws blackish. Length, I4.00-I5.00; extent, 36.00; wing, I1.00-12.00; tail, 5.00-6.00; ear-tufts about 2 inches long, of 8 to 12 feathers. 
Resident, and not uncommon throughout New England. It inhabits woods and thickets, and is seldom seen abroad in daylight, unless startled accidentally from its retreat. Though so similar in form to the Short-eared Owl, and often found in marshy and bushy places with the latter, it has ways of its own, and neither nests on the ground nor is partial to swampy localities. The nest is usually in some thick evergreen tree, and built by the bird itself, though a deserted crow's or hawk's nest is sometimes utilized for the purpose. The eggs are laid in April, numbering from four to six; they are of the usual shape and color, but quite variable in size, varying from $1.4 \mathrm{I}$ to 1.65 in length, by about 1.25 in diameter.

\section{SHORT-EARED OWL.}

\section{Asio accipitrinus (Pall.) Nervt.}

Chars. Above, completely variegated, chiefly in streaks, with fulvous or tawny and dark brown; breast much the same; other under parts paler, usually bleaching on the belly, which is sparsely and sharply streaked (never barred) with dark brown ; feet and crissum usually immaculate whitish or pale tawny; under surface of wings uninterruptedly white. Quills of the wings varied, mostly in large pattern, and tail pretty regularly barred, with the two colors of the upper parts. Facial area white or nearly so, but with large black eye-patch; ruff minutely speckled with fulvous and blackish, white-bordered internally, and usually with a blackish patch behind the ear; radiating feathers of the ear-flap streaked with blackish and fulvous. Iris bright yellow; bill and claws duskybluish. Feet feathered to the claws; soles perfectly naked, granular, yellowish. External ear-parts extremely large, 2 inches or more across the longest way; ear-tufts small, inconspicuous, few-feathered. Length of male, 14.50; extent, 41.00; wing, II.75; tail, 6.00; foot, to end of middle claw, 3.50; chord of culmen, I.10. Female somewhat larger. 
The Short-eared Owl is one of the commonest species, rather more so than the last, and seems to be especially numerous in marshy places along the coast. It is something of a ground Owl, oftener seen in low thickets and brakes than in high woods, and is frequently abroad in the daytime. It sometimes gathers in considerable companies, being one of the few species ever observed "in flocks." This is one of the most patient and persistent hunters of the shrews and field-mice, which, when numerous, are a serious annoyance to the farmer; and on this account deserves to be protected and encouraged, though it is also destructive to various small birds. It may sometimes be observed during the day quartering low over marshy ground, on the lookout for its game; but is oftener startled from its retreat in some thick bush, when it rises as if confused, and hurries off for a few yards to pitch down again out of sight. The nest is usually built on the ground, in a loose, slovenly manner, consisting of a few twigs, grasses, and feathers. The eggs are commonly four to six in number, laid in April ; they are chalky white, subspherical, and measure about 1.55 by 1.25 .

\section{GREAT GRAY OWL.}

\section{Strix Cinerea $G m$.}

Chars. Of largest size ; length about $2 \frac{1}{2}$ feet ; extent, $4 \frac{1}{2}$; wing, $1 \frac{1}{2}$; tail, I or more. Head smooth, without ear-tufts; facial discs complete, and of great extent ; ear-parts moderate, operculate; eyes rather small. Tarsi and toes fully feathered. Above, ashybrown, mottled in waves with ashy-white; below, similar but paler, the markings disposed in streaks on the breast, elsewhere in bars; the great face discs marked in concentric rings of lighter and darker colors; wings and tail with five or six bars. 
This is an Arctic species, decidedly more so than the Snowy Owl even, of infrequent occurrence in northern New England, and rarely straggling as far as Connecticut in winter only. The great size of the bird renders it conspicuous on the rare occasions when it favors us with a flying visit, and perhaps most of its occurrences become known. There is but one Connecticut record, that given by Linsley, of a capture at Stratford, Jan. 6, I843 (Am. Journ. Sci., xliv, I843, p. 253). Mr. Merriam (Rev. B. Conn., I877, p. 70) adduces a Massachusetts record from the History of Lynn, I865, in which is narrated the capture of a specimen near Boston in the winter of 1852 . Dr. Coues catalogues two Massachusetts specimens in the Museum of the Essex Institute, both taken in Essex County, one in the winter of 1866-67, the other in February, 1859 (Pr. Essex Inst., v, I 868, p. 260). Mr. Allen adduces several Massachusetts instances (Pr. Essex Inst., iv., I864, p. $8 \mathrm{I}$; and Am. Nat., iii, I870, p. 570). Mr. N. C. Brown speaks of a specimen in the collection of the Portland Society of Natural History, found dead some years before on one of the islands in Casco Bay; adding that the specimen remained unique for that locality, though he had also examined one taken at Brunswick (Pr. Portl. Society, Apr. I882). Mr. Babcock of Sherborne informs me that an individual was shot many years ago in a large pine swamp near his residence. $\mathrm{Mr}$. Minot speaks of one which he observed in some pine woods near Milton, Mass., early in I875, toward the end of an exceptionally severe winter (B. N. E., I877, p. 331). The great bird may be resident in Northern New England, but we have no advices of its presence there in summer. 


\section{BARRED OWL.}

\section{Strix nebulosa Forst.}

Chars. Resembling the last in form, but much smaller, and otherwise easily distinguished. Length, about 18.00; extent, 40.00; wing, 14.00; tail, 9.00. Upper parts ashy-brown, barred with white and tinged with fulvous; under parts similar, but lighter, the markings in cross-bars on the breast, elsewhere in streaks; the wings and tail barred with brown and white, ashy, or tawny.

A rather common resident species in New England, generally inhabiting thick woods, and not so frequently coming under observation as some of the others. It may easily be recognized by its similarity in form to the Gray Owl, having the same large smooth head and immense facial discs ringed with light and dark colors, in connection with its much smaller size and barred breast. The hooting outcry is also characteristic. The numbers of the birds appear to decrease with the clearing off of the forests to which they are so much attached, but these Owls are still numerous. The nest will be found in the hollow of a tree, or high up in a crotch; the eggs, to the number of three or four, are white and spheroidal, measuring about two inches in length by one and twothirds in breadth; they are usually laid in April. The food of the species, as of others of the family, consists of small quadrupeds, birds, and insects.

\section{SNOWY OWL.}

Nyctea scandiaca (L.) Nerot.

Chars. Of large size; nearly 2 feet long; wing, 17 inches; tail, 9 or 10. The head is apparently smooth, but there are really smali 
ear-tufts, generally overlooked. Facial discs large and complete. Feet densely clothed with feathers. Color white, with more or fewer dark markings, according to age, sex, or other circumstances ; some individuals are nearly white, but the majority are fully spotted with dusky, especially on the upper parts. The general appearance, however, is unmistakable.

Though an Arctic species, this is a very frequent winter visitor in New England, whose appearance is too common and too nearly regular to require any citation of special instances. In some seasons there is a sort of irruption of these birds from the north, and we hear of their capture in all quarters, they being too conspicuous both in size and color to escape attention. Such a case occurred in the winter of 1877 , as re-

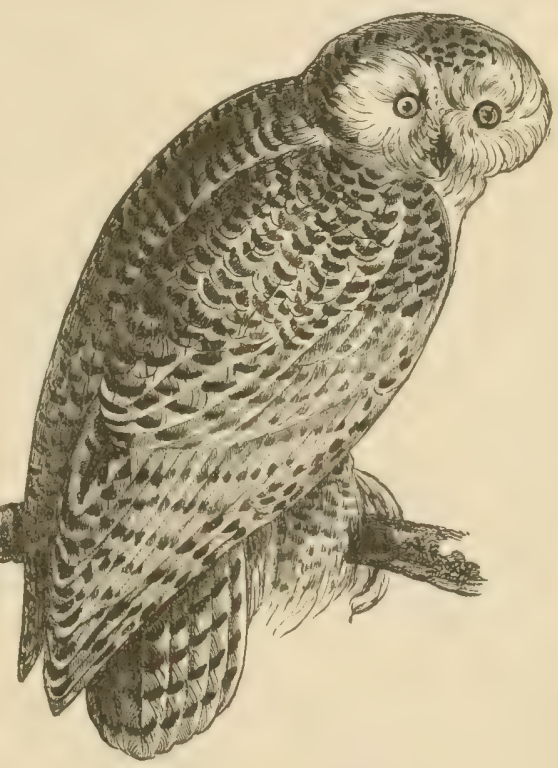
Fig. I8. - SNowy OwL. corded by Mr. Ruthven Deane (Bull. Nutt. Club, ii, Jan., I 877 , p. 9), and many other observers. The great white bird not seldom extends its winter wanderings to the Middle States. The summer home is beyond our limits, and extends to very high latitudes; but, as suggested by Mr. Boardman, the Snowy Owl may yet be found breeding in the woods of Maine. 


\section{HAWK OWL; DAY OWL.}

\section{Surnia funerea (L.) Rich. and Sw.}

Chars. Dark brown above, more or less thickly speckled with white; below, closely barred with brown and whitish, the throat alone streaked; quills and tail with numerous white bars; face ashy, margined with black. Length about I 6.00 ; extent, 32.00 ; wing, 9.00 ; tail, 7.00, graduated, the lateral feathers 2 inches shorter than the central. Except in the length of its tail, which produces linear measurements unusual for a bird of its bulk in this family, its general form is that of the Snowy Owl. Like that species, it is a bird of Arctic regions, coming southward in winter, but its range is more restricted, rarely extending to the Middle States. It is the most diurnal bird of the family, ranging abroad at all times, and approaches a hawk more nearly than any other.

The Hawk Owl doubtless inhabits the woods of Northern New England as a permanent resident, and has actually been observed in Maine during the breeding season; but I am not aware of authentic advices, as yet, of its nesting within our limits. It is recorded from each of the other States, excepting Rhode Island. In Connecticut, it was unknown until I869, when Dr. F. W. Hall procured a specimen in November (Merriam, B. Conn., 1877, p. 73). In Massachusetts it is a rare and irregular winter visitor, but has been on the books since 1833 at least; Mr. Allen gives several instances (Am. Nat., iii, I869, p. 569); I have a specimen taken near Amherst, and Mr. Maynard mentions two examples (Birds E. N. A., 1881, p. 278). Further north, the bird becomes one of regular occurrence in winter. The nest is usually placed in trees; it is composed of sticks, lined with hay, grass and feathers; the eggs are four to six in number, 1.50 to 1.62 long $\times 1.20$ to 1.30 in breadth. 


\section{RICHARDSON'S OWL.}

\section{Nyctala tengmalmi Richardsoni $(B p$.) Ridg.}

Chars. Above, olivaceous chocolate brown, spotted with white; beneath white, spotted and streaked with a brown similar to the back, but a little darker; disc, white ; a white spot between bill and eye ; wings and tail with white spots on both webs, the latter with from 8 to Io pairs. Bill, light yellow; iris, yellow ; tarsus feathered; disc complete. Cere not tumid, the nostrils presenting laterally and obliquely oval. Length, I0.00; extent, 21.00 to 23.00 ; wing, 7.25 ; tail, 4.50 .

Still another of these rare and shadowy night-callers from hyperborean regions - this time a little fellow, much smaller than any of the foregoing excepting Scops, though exceeding the common "Saw-whet" considerably. It is more common in Northern New England, where it is probably resident, like the Snowy and Hawk Owls, and whence it makes its silent and irregular way southward in winter. The Connecticut record is single to date: that of a specimen captured many years ago in midwinter at East Windsor Hill, as recorded by Dr. William Wood in the Hartford Times of Aug. 24, I86 I (Allen, Pr. Essex Inst., iv, I864, p. 52 ; Merriam, B. Conn., I877, p. 73). The Massachusetts instances are several : see, for instance, Allen, as just quoted, and in Am. Nat., iii, 1870, p. 646; Maynard, Nat. Guide, I870, p. I33; and Brewer, Pr. Bost. Soc., xx, 1879, p. 27I. The last named author says: "Mr. Harry Merrill, writing Feb. I4, I879, informed me that he had recently procured an example of this species in the neighborhood of Bangor. It was kept alive for some time, and Mr. Merrill was interested to learn that Mr. Audubon procured the only living 
specimen he had ever seen of this species, in Bangor, in I 832. And Feb. 26, i 879, Mr. Outram Bangs procured a female example near Newton, Mass." In Rhode Island, the bird appeared near Providence in the winter of $188 \mathrm{I}$, as stated by F. T. Jencks (Bull. Nutt. Club, vi, I 88 I, p. 123). The eggs are described as measuring $1.28 \times 1.06$.

\section{SAW-WHET OR ACADIAN OWL.}

Nyctala acadica $(G m$.$) Bp.$

Chars. A small Owl, with the head untufted, the facial discs complete, the ears operculate, the tarsus longer than the middle toe, the tail nearly even, the third quill longest, the first five emarginate. Less than the last: length, under 8.00 ; extent, I7.00; wing, 5.50 ; tail, 2.67 , thus not more than half as long as the wing. Color above chocolate-brown, spotted with white, the tail with transverse white bars; the adult with the facial area and forehead variegated with white, the face and superciliary line grayish-white, the lower parts white, with spots or streaks of the color of the back; the young with the facial area and forehead dark brown, the face dusky, the eyebrows pure white, the lower parts brown, paler on the belly, unmarked. Thus similar to $N$. richardsoni in color, but the bill is black, with tumid cere, and the nostrils open interiorly.

Unlike the three last, this diminutive Owl, the smallest of any to be found in the Eastern States, is a resident inhabitant of our country, and not so uncommon as its infrequent capture or observation might lead one to suppose. Being completely nocturnal, and of such slight personal presence, it is less likely to be seen than are its queer scraping notes, which have been likened to the sharpening of saw teeth with a file, to be heard 
in the depths of the woods the curious little creature inhabits. The nest is usually in the hollow of a tree, where are laid, in April, eggs to the number of four, five, or six, white in color, and of the usual shape for this family, measuring only one inch in length by seveneighths in diameter.

While it is scarcely necessary to enlarge upon the numerous cases of the occurrence of so common a bird, the reader in search of particular instances may be referred to the following late records, attesting its constant presence and breeding in various parts of New England: Coues, Pr. Ess. Inst., v, I 868, p. 260 ; Brewer, Pr. Bost. Soc., xvii, 1875, p. 444; Purdie, Bull. Nutt. Club, i, 1876 , p. 72 ; ii, 1877 , p. I4; Deane, ibid., ii, 1877, p. 84; Allen, Bull. Essex Inst., x, 1878, p. 2 I ; Merriam, B. Conn., I877, p. 74 ; Minot, B. N. E., 1877, p. 334; Brewster, Bull. Nutt. Club, vi, I88I, p. I43; vii, 1882, p. 23.

\section{BURROWING OWL.}

\section{Speotyto cunicularia hypogea $(B p$.$) Coues.$}

Chars. Above, grayish-brown, with white, black-edged spots; below, tawny white, variegated with reddish-brown, chiefly disposed in bars; face and throat whitish; crissum and legs mostly unmarked; quills with numerous paired tawny white spots, and tail-feathers barred with the same; bill, grayish-yellow; claws, black. Length, 9.10 long; wings, 6.50-7.50; tail, 3.50-4.00. No tufts ; facial disc imperfect ; tarsi very long, extensively denuded, bristly like the toes. Prairies and open portions of the United States west of the Mississippi; Florida.

Though we trust our outline of the New England Owls is not a "chapter of accidents," the occurrence of 
the Burrowing Owl in our midst, with note of which we finish consideration of the night-birds of prey, certainly belongs to such a category. One individual of this singular species made its appearance at Newburyport, in Massachusetts, May 4, I875, at which time and place it was done to death by Messrs. H. Joyce and J. K.

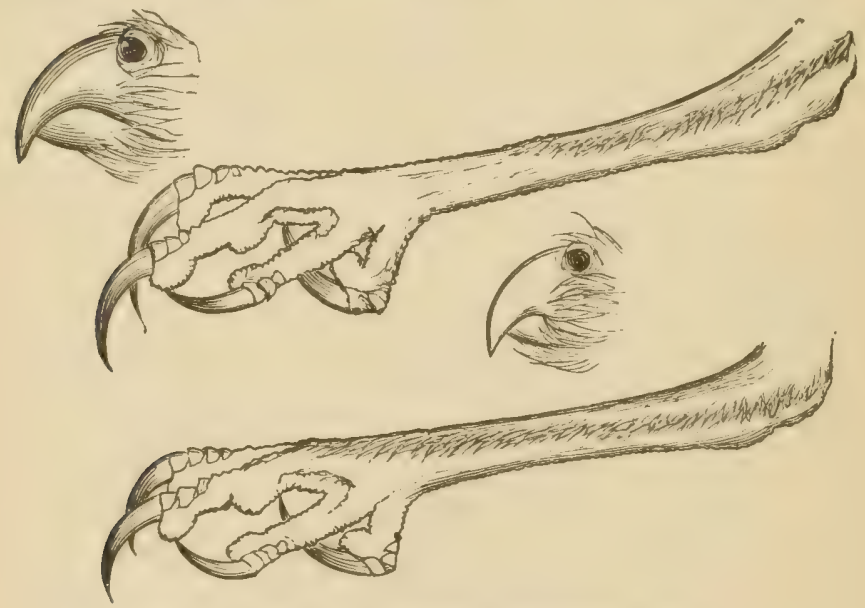

Fig. 19. - Bills and Feet of Burrowing Owls.

Clifford, as originally stated by Mr. Ruthven Deane in the "Rod and Gun" newspaper, vol. vi, May I 5, I875 - as duly repeated by Dr. T. M. Brewer, Pr. Bost. Soc., xvii, 1875, p. 444 ; by Mr. H. D. Minot, B. N. E., I877, p. 343 ; by Mr. J. A. Allen, Bull. Essex Inst., I 878, p. $2 \mathrm{I}$ - and as here again said. Burrowing Owls occur in Florida, and are very common on the Western plains where they live in prairie-dog towns as well as in communities by themselves. Varieties of the same species inhabit portions of the West Indies and South America. 
C. CYANEUS HUDSONIUS: MARSH HAWK, OR HARRIER. IOI

FAMILY FALCONID $巴$ : HAWKS.

\section{MARSH HAWK, OR HARRIER.}

\section{Circus cyaneus hudsonius (L.) Schl.}

Chars. Face with an imperfect disc, somewhat as in the Owls, to which this genus is related. Bill weak, with a lobe on the cutting edge of the upper mandible, but no tooth. Wings, tail, and feet long for the bulk of the bird; the tarsi are scutellate before and behind, and twice as long as the middle toe; nostrils oval. Plumage of the old male remarkably different from that of the female and young. Above, pale ashy blue, nearly unvaried; below nearly white; the quills blackish toward the end. Upper tail coverts conspicuously white on both sexes, at all ages, female and young, above, dark brown streaked with reddishbrown, below, the reverse of this ; tail banded with these colors. Length of male, 16.00-18.00; extent, 40.00; wing, I4.00-15.00; tail, 8.00-9.00; female about 2 inches longer, and other dimensions correspondingly greater.

The Diurnal Birds of Prey, including all kinds of Hawks, Harriers, Kites, Falcons, Eagles, and Buzzards (not the Turkey Buzzard), are well represented in New England, where no fewer than seventeen species or varieties are found - three of them of rare or exceptional occurrence, the remaining fourteen more or less abundant and generally distributed. The first species we present is one of the "ignoble" hawks, of comparatively little spirit and ambition, and altogether little above the level of a "mousing owl." The Harrier flies at the most humble game, feeding chiefly upon fieldmice, shrews, frogs, toads, and insects, and may usually 
be seen quartering low over the ground in search of such quarry. Though it has great sweep of wing, in proportion to its bulk of body, it seems to lack the address, if not also the courage, to cope with creatures possessing good resources for self-preservation or selfdefence. It is particularly attached to low, watery places, where mice and reptiles most abound; and in further evidence of humility, the nest is placed on the ground, - an exceptional manner of nidification

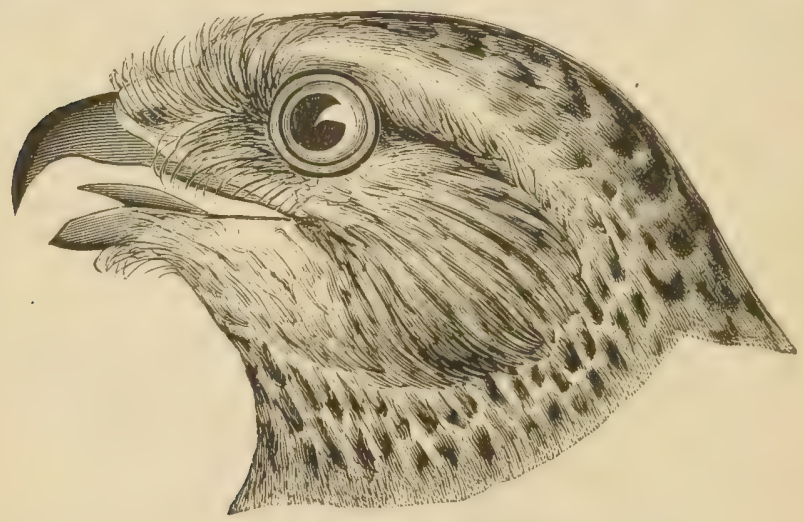

Fig. 20, - Marsh Hawk.

among Hawks. The nest is about a foot in diameter, and three inches in depth, consisting of twigs and grasses, usually without special lining. The eggs, which are laid in May, are four or five in number, measuring (on an average, for they vary much) about $1.85 \times 1.45$. They are pale greenish-white, without bold marking, usually almost uniform, but sometimes with dull obscure spots and blotches of very pale brown, with still paler neutral tint or lavender shell-spots.

The Harrier is one of the common New England Hawks, present during the greater part of the year if 
not the whole, but oftenest seen in spring, summer, and fall, as it moves off when the waters close, and the frogs and mice are in their winter quarters. The opposite sexes are often mistaken for different species, but even our brief description should suffice to correct such error.

\section{SWALLOW-TAILED KITE.}

\section{Elanoides forficatus (L.) Coues.}

Chars. Head, neck, and underparts, white; back, wings, and tail, lustrous black. Tail a foot or more long, deeply forficate; wing, 15-18, pointed; feet small, greenish-blue; claws pale; tarsi reticulate and feathered half-way down in front; toes hardly webbed; nostrils broadly oval. A beautiful bird, common in the South Atlantic and Gulf States, where it is a marked feature of the scenery in regions where the sunbeams are redolent of the orange and magnolia, and where the air reeks with the pestilent miasm of the moss-shrouded swamps that sleep in perpetual gloom. But, imbued with a spirit of adventure, and possessing unequalled powers of flight, it often wanders far from its southern home - to the bleak and windy fields of Dakota, the tamarack fastnesses of Minnesota, the green slopes and gray crags of our own beloved New England.

Its occurrence in this portion of the United States is, however, rare and casual. It was ascribed to Vermont, no doubt correctly, by a writer of the last century, and has been shot on Long Island. Coming to later dates we find Mr. Allen speaking of its appearance at Whately, Mass., about I868 (Am. Nat., iii, I870, p. 645); and Mr. Merriam cites two Connecticut instances (B. Conn., I 877, p. 76). One of these occurrences was at Lyme, New London Co., July 2, I 877 ; the other in the vicinity of Portland, in the summer of r86r. Although the bird 
was shot in neither of these cases, we presume there could be no mistake in identifying an individual of so remarkable a species.

\section{SHARP-SHINNED HAWK.}

\section{Accipiter fuscus $(G m$.) $B p$.}

Chars. Bill short, stout, very high at base for its length, without tooth. Legs extremely slender. Tarsus feathered but a little way down in front, the bare portion longer than the middle toe; tarsal scutella frequently fused. Toe, long, slender, much webbed at base, and padded underneath. Fourth quill longest, second shorter than sixth, first very short. The ordinary plumage is dark brown above (deepest on the head, the occipital feathers showing white when disturbed) with an ashy or plumbeous shade which increases with age, till the general cast is quite bluish-ash; below, white or whitish, variously streaked with dark brown and rusty, finally changing to brownish-red (palest behind and slightly ashy across the breast) with the white then only showing in narrow cross-bars; chin, throat, and crissum mostly white with blackish pencilling; wings and tail barred with ashy and brown or blackish, the quills white-barred basally, the tail whitishtipped. Bill dark; claws black ; cere and feet yellow. Length of male, I0.00-I2.00; extent, 22.00 ; wing, 6.00-7.00; tail, 5.006.00 square; female an inch or two longer, and correspondingly larger in other dimensions.

This spirited and dashing little Hawk is one of New England's common species, especially in the breeding season; for it chiefly withdraws from our limits cluring the colder months, probably not passing the winter except in our southern districts. It is commonly known as the "Pigeon Hawk;" but that name belongs properly to the small species of Falco (not Accipiter) de- 
scribed beyond as $F$. columbarius, and local naturalists should be careful to make the proper discrimination, especially when they speak of the nest and eggs. The present is much more abundant than the true Pigeon Hawk, and in most sections one of our best known birds of prey. It preys chiefly upon small birds and quadrupeds, captured in the dashing manner of all the species of this group, and, like its small allies, feeds to some extent upon insects; the size of its quarry is sometimes not inferior to that of the bold hunter itself, and nothing can surpass the impetuosity with which this Hawk makes its attacks. It nests in trees, or on rocks, preferably the former, laying four or five eggs. They are difficult of concise description, because so variable. The white ground-color has often a livid or even purplish tint, and is marked, often so thickly as to be obscured, with large, irregular splashes of various shades of brown, interminably changeable in number, size, and pattern, sometimes inclining to form masses or a wreath, sometimes more evenly distributed. The egg is of nearly equal size at both ends, and measures about $\mathbf{I . 4 5}$ by I.I 5. The bird is a late breeder, laying commonly the latter part of May, and early in June. The nest is usually placed high in a tree, preferably an evergreen, and built of sticks or twigs, in the crotch of a limb, but sometimes the deserted nest of a squirrel is selected and repaired to suit.

\section{COOPER'S HAWK; CHICKEN HAWK.}

\section{ACCipiter COOPERI $B p$.}

Chars. Coloration and changes of plumage the same as those of $A$. fuscus. Form stouter, and size much greater. Feet moder- 
ately stout; bare portion of tarsus shorter than middle toe; the tarsal scutella always distinct. Tail a little rounded. Length of male, 16.00-18.00; extent, about 30; wing, 9.00-10.00; tail, 7.00-8.00; female averaging about 2 inches longer than the male, the wing and tail an inch longer. In this species the whole foot, though relatively shorter than that of $A$. fuscus, is four inches or more in length; in fuscus the same part is only 3.50 , or less.

Cooper's Hawk is one of our most abundant species, particularly in the lower tier of States; it is chiefly a

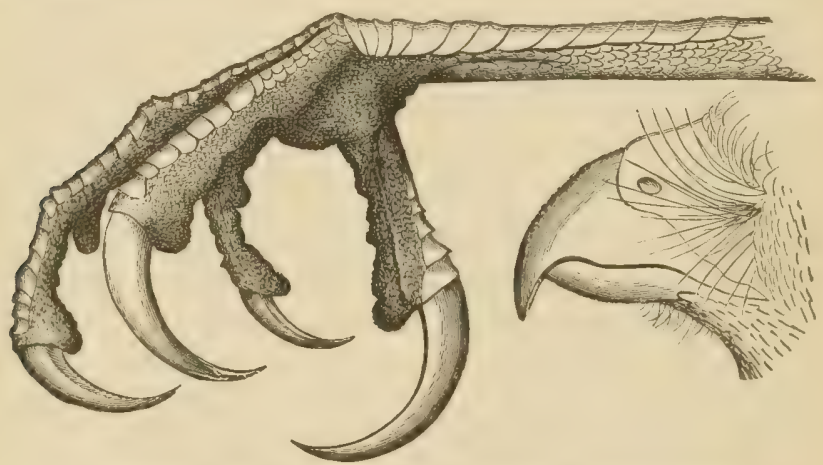

Fig. 21. - Bill and Foot of Cooper's Hawk, nat. size.

summer resident, but many individuals remain through the winter. For audacity and address in capturing birds and quadrupeds of considerable size, it is surpassed by few of its tribe, while its physique is sufficiently powerful to enable it to play havoc with domestic poultry. Its common name of Chicken Hawk is earned by its exploits in the barn-yard, where its raids are no less frequent than successful. It not seldom strikes down birds bulkier than itself, and in fact too heavy for it to fly away with.

Numbers additional to those that winter with us make their appearance in March, and it is not till the following 
November that the visitants move southward. The birds pair in April, and lay the latter part of this month or early in May. The nest is usually high in a tree, preferably an evergreen, resembling that of a Crow; the birds usually build for themselves, but sometimes fit up a Crow's nest, or the nest of some other Hawk, to suit their purposes. They appear to be devoted and assiduous progenitors, if the way they persist in their efforts, under discouraging circumstances, be taken as any criterion. More than one instance has been recorded of their laying at least thrice, when their nest has been repeatedly robbed. Three, four or five eggs may be found in the nest. They measure from $\mathrm{I} .80$ by I. 55 to 2. 10 by $1.60-$ figures showing the variation both in size and shape - they average about I.90 by I.5O. They resemble those of the Marsh Hawk so closely as to be not certainly distinguishable, but they are usually more globular, and with a more granulated shell. The greatest diameter is at or very near the middle ; difference in shape of the two ends is rarely appreciable. They are usually more uniform in color than those of most hawks, normally resembling the pale, scarcely-marked examples occasionally laid by most species. The ground-color is a white, faintly tinted with pale bluish or greenishgray; if marked, it is with faint, sometimes almost obsolete, blotches of drab, liable to be overlooked without close inspection; only an occasional specimen is found with decided, though still dull and sparse, markings of pale brown. 


\section{AMERICAN GOSHAWK.}

\section{Astur atricapillus (Wils.) Bp.}

Chars. Adult, dark bluish-slate blackening on the head, with a white superciliary stripe ; tail with four broad dark bars; below, closely barred with white and pale slate, and sharply streaked with blackish. Young, dark brown above, the feathers with pale edges, streaked with tawny-brown on the head and cervix; below fulvous-white with oblong brown markings. Female 2 feet long; wing, I 4 inches; tail, I I m male smaller. A large, powerful, and, in perfect plumage, a very handsome hawk, inhabiting northern North America; the northern half of the United States chiefly in winter.

This noble hawk, one of the handsomest birds of the family when in perfect plumage, is a decidedly boreal species, entirely wanting in the southern portions of the United States, appearing only in winter, and in small numbers, in the middle districts, but common along our northern frontier. According to the records examined, it is, as a rule, rare in Southern New England, where, however, it appears some winters in considerable numbers. Mr. Allen remarks that it was common in Massachusetts in the winter of I859-60; and Mr. Samuels states that the same season he received a dozen or fifteen specimens from the vicinity of Boston. The only region in the United States where it is reported as regularly resident is Northern New England, where, both Mr. Boardman and Prof. Verrill state, it is of common occurrence, and breeds. But it has been seen in summer in Massachusetts, and doubtless breeds in that State. Mr. Maynard describes the eggs as three or four in number, rather spherical in shape, of a 
bluish-white color, either immaculate or finely mottled with pale reddish-brown; the size, 2.30 by 1.82 to 2.32 by 1.92. According to Dr. Brewer, the egg of the Goshawk is $2 \frac{5}{16}$ long by $1 \frac{1}{16}$ broad, nearly spherical, roughly granulated, soiled white, with a faint bluish shade, "marked irregularly with large but quite faint blotches of drab and yellowish-brown." It thus closely resembles that of Cooper's Hawk, differing chiefly in its larger size; and the nidification is represented as being the same in essential particulars. In the nature of its prey, its mode of securing it, its general habits and nature, we find it also much the same, the only difference resulting from its superior prowess, if not more ferocious nature.

\section{GYRFALCONS OR JERFALCONS.}

\section{Falco gyrfalco $L$.}

Chars. Tarsus feathered fully half-way down in front, with only a narrow bare strip behind, irregularly reticulate on the bare parts; longer than the middle toe. First quill shorter than the third; second quill longest; first alone decidedly emarginate on the inner web. Upward of 24.00 long; wing, about I6.00; tail, I0.00. Bill with a sharp tooth on cutting edge of upper mandible; the end of the under mandible notched or truncate. Nostrils with a centric tubercle. Color white, with dark markings, much as in the Snowy Owl; or, ash-colored with numerous lighter bars ; or, quite blackish. Young, longitudinally striped on under parts. An arctic Fa'con of circumpolar distribution, in this country reaching the Northern States. It is split into several varieties, which, however, do not seem to be strictly geographical, and concerning which ornithologists are singularly agreed to disagree - inter negotia talia, cuique suum. In var. candicans, which is the best marked form, inhabiting North Greenland and 
other high latitudes, the white predominates over the dark markings; the bill and feet are whitish. This form is probably never seen in the United States. In var. islandicus, dark markings predominate; the bill and claws are dark; the crown is lighter than the back, and the dark moustaches are slight. This form occurs in New England, as a rare winter apparition. The var. sacer, the North American representative of $F$. gyrfalco of Northern Europe, is like the last, but with the crown darker than the back, and the moustaches heavy; it is believed to have been seen in New England. Var. obsoletus is still darker, quite blackish; this form even breeds in New England.

Dark-colored Gyrfalcons are of occasional occurrence in New England, notes to which effect run many years back in the history of the subject. Of late, one form, the darkest of all, has been ascertained to reside in Northern New England. Specimens supposed to represent two other varieties have also been taken at various times. The form candicans has apparently never occurred, though the name has been repeatedly attached to New England examples of Gyrfalcon.

Mr. Purdie has obligingly looked up the later records with the following result:

F. gyrfalco obsoletus. Massachusetts, two instances: Breed's Island, Boston Harbor, Oct., I876, Cory, Nuttall Bull., ii, I 877, p. 27 ; Essex County, Purdie, ibid., iv, I 879, p. I89. Dumerston, Vermont, a rare resident, Brewer, Pr. Bost. Soc. Nat. Hist., xvii, I875, p. 444. Calais, Me., Brewer, ibid., xix, I878, p. 306; Boardman, Pr. Bost. Soc. Nat. Hist., ix, I862, p. I22, under name of "F. candicans."

F. gyrfalco sacer (Forst.) Maine, Piscataquis Co., one instance, believed to be its first recognized occurrence in Eastern U. S., certainly the first in New England: Purdie, Nutt. Bull., iv, I879, p. I88. (Does the " $F$. 
gyrfalco" of Allen, Bull. Essex Inst. x, i878, p. 2 i, No. I64, belong here or to the next form ?)

F. gyvfalco islandicus. Rhode Island, one specimen, near Providence, winter of I864-'5: Allen, Am. Nat., iii, I869, p. 513 ; this specimen, given by Allen as $F$. sacer, has since been identified with islandicus; see Hist. N. A. Birds, iii, I874, pp. I I4, I I 5.

Here may belong also the following records: $F$. islandicus, Putnam, Pr. Essex Inst., i, I856, p. 226, Seekonk Plains, Mass. (same record as quoted by Allen; Pr. Essex Inst. iv, I 864, p. 8I, under name of F. candicans, and in part the same as quoted by Coues, Pr. Essex Inst., v, I868, p. 254, under name of $F$. sacer $)$. F. candicans, Verrill, Pr. Essex Inst., iii, I862, p. I 39; "not uncommon" at Norway, Me. F. sacer, Maynard, Nat. Guide, I870, p. I 34, and Pr. Bost. Soc. Nat. Hist., xiv, 1872, p. 382. Hicrofalco gyrfalco islandicus, Brown, Pr. Portland Soc. Nat. Hist., Apr. I882; Portland, Me.

\section{DUCK HAWK: PEREGRINE FALCON.}

\section{Falco peregrints Tunstall.}

Chars. Tarsus feathered but a little way above in front, not longer than middle toe. First quill not shorter than third; second longest; first alone decidedly emarginate on inner web. Nostril with a central tubercle; bill toothed as in all the true Falcons. Length about I 8 inches; wing, $13.00-14.00$; tail, 7.008.00. Above, blackish-ash, with more or less evident pale edging of the feathers. Forehead and under parts white with more or less fulvous tinge, and blackish transverse bars; conspicuous black cheek patches. Young with the upper parts browner, the tawny shade below stronger, the under parts striped lengthwise. 
The Peregrine occurs at intervals in all suitable places in North America, and it is not a little remarkable that its extensive breeding range should have only lately been ascertained. Mr. Allen, with the assistance of Mr. C. W. Bennett and Dr. W. Wood, of East Windsor Hill, Connecticut, have been conspicuous in elaborating the history of the species, and especially in establishing the fact that it regularly breeds on several of the mountains in and near the Connecticut River Valley. Mr. Boardman reports the same item from Grand Menan, where, he says, the bird is resident, and regularly breeds on the

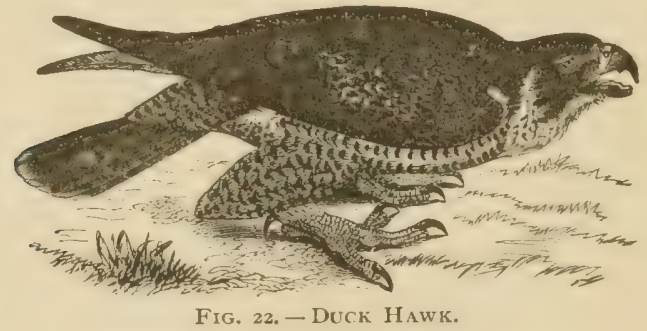

cliffs. Dr. Wood, in the Hartford Times of June 29, I 86I, states that four nearly fledged young were taken from a nest on Talcott Mountain, near Hartford, June I, I86I, the female parent being shot. Writing in I864 (Pr. Essex Inst., iv, I864, p. 50), Mr. Allen states that Mr. Bennett took young birds, "a few years since," on Mount Tom, near Springfield, Massachusetts. Shortly afterward, Mr. Allen announced the discovery of the eggs by Mr. Bennett, on Mount Tom, April 19, I864; these were the first known to have been procured in New England, or, indeed, in the United States. The unusual interest attaching to his article induces us to quote at some length : 
"Although the Duck Hawk has been long known to breed at the localities in Massachusetts mentioned above [Mounts Tom and Holyoke], those conversant with the fact were not aware that any special interest was attached to it, or that its eggs and breeding-habits were very little known to ornithologists; and so, until very recently, no particular efforts have been made to procure the eggrs. Mr. Bennett, becoming aware of this, resolved to procure the eggs. He accurdingly visited Mount Tom for this purpose, April 6th of the present year [I 864], when he searched the whole ridge of the mountain, discovered the old birds and the particular part they most frequented, and also the site of a nest, where the young had been raised. The old birds were continually near this spot, and manifested much solicitude when it was approached, often flying within six or eight rods, and once the female came within three, screaming and thrusting out her talons, with an expression of great rage and fierceness. The birds did not appear at all shy, being easily approached quite nearly, though, in walking, the cracking of sticks and the clinking of splinters of traprock made no little noise. One of the birds appeared to keep close to the eyrie, and both would approach whenever it was visited, screaming at and menacing the intruder, notwithstanding that at that time there were no eggs. Mr. Bennett, suspecting that incubation had commenced, visited the locality again on the gth, but only saw the old nest, the birds behaving as before. Ten days later he made another visit, and, creeping carefully to the summit of the cliff, at a point near the eyrie already spoken of, he saw the female, on looking over the cliff, sitting on the nest, and but five or six yards distant. She eyed him fiercely for an instant, and then, scrambling 
from the nest to the edge of the narrow shelf supporting it, launched into the air. In a twinkling Mr. Bennett's unerring aim sent her tumbling dead at the foot of the precipice, several hundred feet below. The nest contained four eggs, which were soon safely secured, and the body of the female was obtained from the foot of the cliff. The male soon coming about was shot at, but he was too shy to come within range, excepting once, when the gun was being reloaded. The eggs were all laid after April 9, and their contents showed, April I9, that they had been incubated but a day or two. Incubation seems, in this case, to have commenced several weeks later than usual, which may have been owing to the late snows and unusual coldness of the weather this year during the first half of April.

"The situation of the eyrie was near the highest part of the mountain, about one-third of the length of the mountain from its south end, on a narrow shelf in the rock, eight or ten feet from the top of a nearly perpendicular cliff, I 50 or 200 feet in height, and was inaccesible except to a bold climber, and at one particular point. The nest was merely a slight excavation, sufficient to contain the eggs; no accessory material had been added. The site had been previously occupied, and probably for several years; and for weeks before the eggs were laid was carefully guarded by the bold and watchful birds."

These four eggs averaged 2.22 long by I.68 broad, with 2.22 by $1.7 \mathrm{I}$, and 2.16 by $\mathrm{I} .65$ as maxima and minima, respectively. The smallest was larger than the one measured by Dr. Brewer (2.00 by 1.56 ), which he obtained in Labrador. They also varied considerably in contour, and in heaviness and extent of coloration they showed a scries from the darkest and most nearly uniform to the lightest 
and most sparsely marked, in which latter the contrast between the white ground and the blotches was striking. Of the darkest egg the writer says: "The general color is chocolate-brown, darker and more dense and uniform about the ends, the part about the middle being lighter, varied with small irregular blotches and specks of a darker tint than the ground color. The color of the smaller end is a nearly uniform dull red ochre. There is also an irregular belt of scattered and apparently very superficial blotches of very dark brown or nearly black." Two other eggs, as already mentioned, graded toward the lightest, which is thus described: "The greater end of the egg, which in the egg of most birds is the end most subject to markings and to the greatest depth of color, is white, sprinkled sparingly with reddish specks; while the smaller end is deep bright brick-red, here and there relieved by small specks and patches of white ground color. About the middle of the egg the colors are in more equal proportions, the white patches becoming larger on the smaller end toward the middle, and the red patches on the larger end increase toward the same point, where the colors meet and become mixed in irregular patches of various sizes, from mere dots to blotches."

Mr. Allen continues the subject in his latter communication to the American Naturalist (iii, 1869, p. 5 I4). "One or more pairs of these birds have been seen about Mounts Tom and Holyoke every season since the first discovery of their eggs at the former locality, in 1864 . Mr. Bennett has since carefully watched them, and his frequent laborious searches for their nests have been well rewarded. In I 866 he took a second set of eggs, three in number, from the eyrie previously occupied. In 1867 the male bird was killed late in April, and this 
apparently prevented their breeding there that year, as they probably otherwise would have done; at least no nest was that year discovered. In I 868 Hawks of this species were seen about the mountains, and, although they reared their young there, all effort to discover their nest was ineffectual. The present year (1869) they commenced to lay in the old nesting-place, but as they were robbed when but one egg had been deposited, they deserted it, and chose a site still more inaccessible. Here they were equally unfortunate; for, during a visit to the mountain in company with Mr. Bennett, April 28, we had the pleasure of discovering their second eyrie, and from which, with considerable difficulty, three freshlylaid eggs were obtained. Not discouraged by this second misfortune, they nested again, this time depositing their eggs in the old eyrie, from which all, excepting the last set of egrs, have been obtained. Again they were unfortunate, Mr. Bennett removing their second set of eggs, three in number, May 23 , at which time incubation had just commenced. The birds remained about the mountain all the summer, and, from the anxiety they manifested in August, it appears not improbable that they laid a third time, and at this late period had unfledged young.

See also the interesting article by Dr. Wood in the American Naturalist, v, I87 I, p. 82. Our latest accounts of the nidification are given by Mr. F. H. Knowlton in the Nuttall Bulletin, v, I880, p. 57, from observations made at Brandon, Vermont, where a pair of Duck Hawks are known to have bred for more than twenty years.

As to the distribution of the Duck Hawk in New England there is little to note, the bird being of general though infrequent or irregular occurrence, excepting in 
the particular localities to which it happens to resort to breed. Mr. Allen cites it for Massachusetts as a "rare resident; more common in winter than in summer, and along the coast than in the interior." Its breeding in Connecticut, where, however, it is not a common bird, has already been noted. Mr. N. C. Brown has lately instanced the only case of its occurrence near Portland, which has come to his knowledge.

\section{PIGEON FALCON : PIGEON HAWK.}

\section{Falco columbarius L.}

Chars. Tarsus scarcely feathered above, with the plates in front enlarged, appearing like a double row of alternating scutella (and often with a few true scutella at base); Ist and $2 \mathrm{~d}$ quills emarginate on inner web. Adult male above ashy-blue, sometimes almost blackish, sometimes much paler; below pale fulvous, or ochraceous, whitish on the throat, the breast and sides with large oblong dark brown spots with black shaft lines; the tibiæ reddish, streaked with brown; inner webs of primaries with about eight transverse white or whitish spots; tail tipped with white, and with the outer feather whitening; with a broad subterminal black zone and 3-4 black bands alternating with whitish; cere greenish-yellow, feet yellow. Female with the upper parts ashybrown; the tail with 4-5 indistinct whitish bands. Length, about I 3.00 ; wing, 8.00 ; tail, 5.00 ; male smaller. Observe that Accipiter fuscus is also called "pigeon hawk."

According to Dr. Brewer, this spirited little falcon is a migratory visitant in Southern, and a summer resident in Northern New England. Dr. Coues says: "Generally distributed, not abundant; resident; breeds at least as far south as Massachusetts. Individuals are of general occurrence throughout New England." Mr. J. N. Clark 
records it from Saybrook, Ct., "as very common in the migrations." Mr. Allen says for Massachusetts: "rather rare, chiefly occurring in spring, fall, and winter;" and Mr. Merriam says: "that in Connecticut, it is not uncommon in spring and fall, and has been observed in May, June, and July, with the inference of its breeding in that state."

There has been so much doubt and uncertainty regarding the eggs of this Falcon, that we are the more pleased to offer an unquestionable description, derived from examination of specimens in the Smithsonian. The size varies from 1.50 by 1.30 to 1.80 by I.3O-figures also indicating the range of variation in shape, some being subspherical, others elongate-oval. Coloration ranges from a nearly uniform deep rich brown (chestnut or burnt sienna), to whitish or white only, marked with a few indistinct dots of dull grayish or drab. Such extremes are connected by every degree; a yellowish-brown ground-color, irregularly splashed with rich ruddy brown, is the usual style. The markings may be very evenly distributed, or mostly gathered in a wreath around one or the other end, or even both ends.

\section{RUSTY-CROWNED FALCON: SPARROW HAWK.}

Falco sparverius $L$.

Chars. Crown ashy-blue, with a chestnut patch, sometimes small or altogether wanting. sometimes occupying nearly all the crown ; conspicuous black maxillary and auricular patches, which with three others around the nape make seven black places in all, but a part of them often obscure or wanting; back cinnamon brown, in the male with a few black spots or none, in the female 
with numerous black bars; wing coverts in the male ashy-blue, with or without black spots, in the female like the back; quills in both sexes blackish with numerous pale or white bars on the inner webs; tail chestnut, $\bullet$ in the male with one broad black subterminal bar, white tip, and outer feather mostly white with several black bars; in the male the whole tail with numerous imperfect black bars; below white, variously tinged with buff, or tawny, in the male with a few black spots or none, in the female with many brown streaks; throat and vent nearly white and immaculate in both sexes; bill dark horn, cere and feet yellow to bright orange. Length, 10.00-11.00; wing, 7.00; tail, 5.00 , more or less.

This elegant little Hawk will be immediately recognized by its small size, and entirely peculiar coloration, although the plumage varies almost interminably. It is a common New England bird, and resident, though less numerous in winter than at other seasons. It is also somewhat locally distributed.

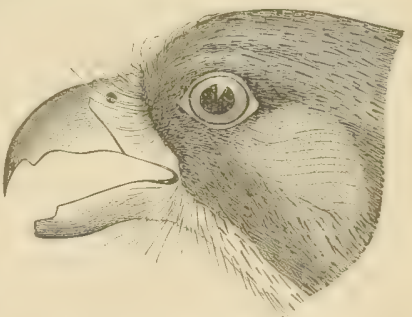

Fig. 23. - Starrow Hawk. Thus, I have found it to be quite abundant in the vicinity of Amherst, where nests are found nearly every year, and specimens are frequently procured. As far as I can ascertain, it builds no nest, but lays its eggs in the hollow of a tree, usually twenty or thirty feet from the ground, or even more. Dr. Wood has described a novel site chosen by a pair at Granby, Connecticut, who attacked and killed a pair of doves, took possession of the dove-house, which was inside a barn with holes leading outward, and made themselves quite at home; they laid four eggs, and began to incubate, with the evident intention of feeding on the farmer's 
chickens : so they died the death. Five or six eggs appear to be the usual nest-full ; seven are stated to have been found in one clutch. They are nearly spheroidal, measuring about 1.33 in length by 1.12 in breadth. The ground-color is usually buffy, or pale yellowish-brown; this is blotched all over with dark brown, the splashes of which are usually largest and most numerous toward the greater end, at or around which they may run into a crown or wreath. Some eggs are pale brown, minutely dotted all over with dark brown; some are white, with pale brown spots; and a few are whitish, without any markings. It is a known fact that this Hawk will lay again in the same nest if robbed of its eggs. An instance is recorded of two sets of five eggs being taken in succession from one nest.

I have successfully reared the young, which exhibited affectionate docility, refusing to leave when set at liberty and returning at intervals to be replaced in its cage. Dr. Coues narrates that while he was at Columbia, in South Carolina, a neighbor had three Sparrow Hawks for some time. As they had been taken from the nest when quite young, they became in a measure reconciled to captivity. They ate any kind of meat freely, and as they grew up, began to display much of their natural spirit. When tormented in the various ingenious ways people have of "stirring up" caged birds, they would resent the indignity by snapping the bill, beating with the wings, and clutching with their talons at the offending cane or umbrella tip. One of them was a cripple, having a broken leg very badly set, and the other two used to bully him dreadfully. One night, whether from not having been fed sufficiently, or being in unusual bad humor, they set upon him, killed him outright, and almost devoured him. 


\section{RED-TAILED BUZZARD: HEN HAWK.}

\section{Buteo borealis $G m$.}

Chars. Adult dark brown above, many feathers with pale or tawny margins, and upper tail-coverts showing much whitish; below white or reddish-white, with various spots and streaks of different shades of brown, generally forming an irregular zone on the abdomen; tail above bright chestnut red, with subterminal black zone and narrow whitish tip, below pearly gray; wing-coverts dark. Young with the tail grayish-brown closely barred with darker, the upper parts with tawny streaking, the under parts white with dark markings, usually wanting on the breast. The young are a long time in acquiring the full plumage. They are long full grown before the red of the tail appears, and this is usually in advance of the fulvous of the under parts that the old birds display. I have seen specimens with nearly perfect red tail, yet showing pure white on the breast and the same elsewhere underneath, though marked with the usual dark-brown spots and streaks. A large stoutlybuilt hawk; female 23.00 ; wing, 15.50 ; extent, 50.00 or more; tail 8.50 ; male 20.00 ; wing, 14.00 ; tail 7.00 . Four outer primaries emarginate on inner webs; tarsus short, stout, extensively feathered above.

This is the largest and most powerful of the Buzzard Hawks, and only exceeded in these respects by the Gyrfalcons. It is a permanent resident, and one generally distributed. You may see the great bird perched erect and watchful, on some lone tree that gives command of a wide horizon, no less mistrustful of the approach of man than confident of its own ability to capture the quarry its keen eye is so eager to descry; or you may notice it again, single or two together, circling high over head in graceful gyration with motionless wings, ever and again sending forth its shrill note of defiance. Still it is on the whole of sluggish and heavy disposition, 
and is unfitted as well by physical organization for the deeds of daring address, for which the Falcones and Astures are so famous. It is not quick enough to strike

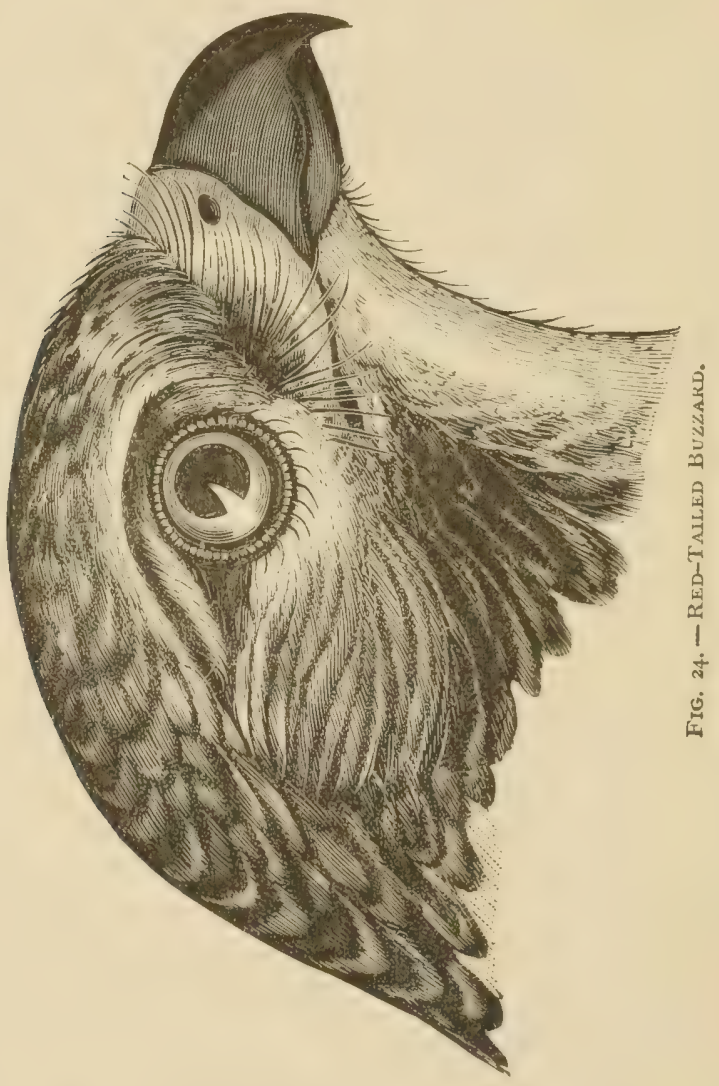

birds on the wing, and perforce contents itself with humbler, less active and more defenceless game.

These Buzzards mate early, constructing a large and bulky, though shallow, nest in a high tree, of sticks and 
smaller twigs, mixed toward the centre with grass, moss, or other soft material, and often a few feathers. The same nest is often used during successive years. The eggs are generally three in number, sometimes two or four, about 2.40 long by rather less than 2.00 broad. They are clull whitish in color, sometimes with only a few markings of dull brownish-gray, but oftener extensively blotched with several shades of rich brown. They may be looked for in April, the young usually being out by the end of that month.

\section{RED-SHOULDERED BUZZARD; WINTER HAWK.}

\section{Buteo Lineatus (Gm.) Jard.}

Chars. General plumage of the adult of a rich fulvous cast; above, reddish-brown, the feathers with dark brown centres; below a lighter shade of the same, with narrow dark streaks and white bars; quills and tail blackish, conspicuously banded with pure white, the bend of the wing orange-brown. Young plain dark brown above, below white with clark streaks; quills and tail barred with whitish. Nearly as long as B. borealis, but not nearly so heavy; tarsi more naked; female 22.00; extent, 48.00; wing, I4.00; tail, 9.00; male I9.00; wing, I3.00; tail, 8.00.

This is the most abundant of all our large hawks, resident throughout the year, and in fact the usual representative of its tribe in winter. Its habits are in all respects similar to those of the Red-tail, though it is inferior in size and strength. The nest is much the same in character, but smaller, more likely to be farther from the main stem of a tree; it is said to be not so long reoccupied. The eggs, as usual, have a wide range of 
variability in size and color, but they are usually more highly-colored than those of the Red-tail, just as the general plumage of the bird is, the pale or nearly white varieties being rare. In size they range from 2.00 to 2.25 in length by about 1.75 in breadth; the usual number is three or four, sometimes five, and even six have been found in the nest in one instance.

\section{SWAINSON'S BUZZARD.}

\section{Buteo swainsoni $B p$.}

Chars. Three outer quills emarginate on outer web. Extremely variable in color, but usually showing a broad dark pectoral band contrasted with light surroundings and numerous (8-I2) narrow dark tail bars. A smaller bird than the foregoing; female about 20.00; wing, I6.00; tail, 8.50; male less; not so stoutly built; wings and tail relatively longer; chiefly Western North America, also Canada and Massachusetts. A western species, of casual occurrence in our country, thus far in two known instances.

Mr. Wm. Brewster sums up the evidence of this rare visitor as follows: "The claim of the above-named species to be regarded as a bird of New England has hitherto rested solely upon a specimen in melanistic plumage (formerly specifically separated as $B$. insignatus) shot a few years since at Salem, Mass., and now in the Museum of the Peabody Academy (as recorded by Allen, Bull. Essex Inst., x, I878, p. 22). It is with pleasure that I can now announce the capture of a second individual at Wayland, Mass., on or about September I2, 1876. Through the kindness of Mr. Arthur Smith, of Brookline, to whom it was originally sent in the flesh, this bird has recently come into my possession. It is a 
young male in nearly perfect autumnal dress, and though not typically melanistic, it still inclines strongly towards that condition." (Bull. Nutt. Club, iii, I878, p. 39.)

\section{BROAD-WINGED BUZZARD.}

\section{Buteo pennsylvanicus (Wils.) Bp.}

Chars. Above, umber-brown, the feathers with paler, or even with fulvous or ashy-white, edging, those of the hind head and nape cottony-white at base; quills blackish, most of the inner webs white, barred with dusky; tail with about three broad dark zones alternating with narrow white ones, and white-tipped; conspicuous dusky maxillary patches; under parts white, or tawny, variously streaked, spotted or barred with rusty or rufous, this color usually predominating in adult birds, when the white chiefly appears as oval or circular spots on each feather ; throat generally whiter than elsewhere, narrowly dark-lined. In the young, the upper parts are duller brown, varied with white, the under parts tawny-whitish with linear and oblong dark spots, the tail grayish-brown with numerous dark bars. Female 18.00 ; extent, 40.00; wing, 11.00; tail, 7.00; male less. A rather small but stout species, with short broad wings, very different from any of the foregoing; the maxillary patches are a strong feature.

A resident species in New England, but less common than the Red-tail or Red-shoulder, and seldom to be seen in winter, when probably only in southern portions. The general habits are not peculiar in comparison with those of its allies, and the nidification is similar.

Mr. Samuels states that a nest he visited the 2oth of May, 1864, in West Roxbury, Massachusetts, was built in the fork of a tall pine-tree, near the top, and composed of coarse sticks and twigs, lined with red cedar bark, leaves, and feathers. It contained four eggs, measuring 
from 2.00 to 2.15 long, by 1.70 to 1.72 broad; dirty yellowish-white, covered more or less thickly in the different specimens with spots and blotches of reddishbrown. Other specimens had fainter markings, while in others, again, the spots were finer and darker. The nest, of which little was learned until of late years, has been found frequently in Massachusetts, near Boston, Springfield, Williamstown, Newton, West Roxbury, and Leverett; in the latter place, on Mount Toby, the bird is apparently a regular breeder, both on the Leverett and on the Sunderland side. In Connecticut, Mr. Merriam says: It breeds sparingly about New Haven, and Mr. W. W. Coe has taken quite a number of their nests, together with several of the finest birds that I have ever seen in the vicinity of Portland, Conn. (B. Conn. I877, p. 87.)

\section{ROUGH-LEGGED BUZZARD.}

\section{Archibuteo lagopus sanct-johannis (Gm.) Ridg.}

Chars. Large hawks with the tarsi feathered in front to the toes; about 2 feet long; wing 16.00-I 8.00 ; tail 8.00-10.00. Four outer primaries emarginate on inner web. Below, white, variously dark-marked, and often with a broad black abdominal zone; but generally no ferruginous. North America; abundant. The so-called "black hawk" is a melanotic state, in which the whole plumage is nearly uniform blackish.

This large Hawk, in black or the other plumage easily recognized by the feathered shank, is a northerner; seldom, if ever, found in summer in our country; though the black variety is given by Dr. Brewer as resident in Maine. It is a bird of very irregular distribution; being particularly attached to low wet meadows, 
such as are affected by the Harriers and Short-eared Owls, it is almost necessarily local and scattering. Though of great size, its prey is very humble, consisting chiefly of mice, reptiles, and insects. The nest is placed indifferently on trees or cliffs. The eggs, three or four in number, and measuring about $2 \frac{1}{3}$ by $\mathrm{I}_{4} \frac{3}{4}$ inches, run through the usual variations, from dull whitish, scarcely or not at all marked, to drab or creamy, largely blotched with different shades of brown, sometimes mixed with purplish slate markings.

Although belonging to a group technically said to be "ruling" Buzzards ("Archibuteo"), it is difficult to see where the claim to royal purple lies in this species and others of the same genus, for they certainly lack the qualities that go to make hawks famous. Viewing their splendid presence, we wonder, as a late writer says, "that the object of such an admirable organization is nothing more important than the destruction of the smallest and most defenceless of quadrupeds or of reptiles. Yet such is apparently the case. Many of the birds of this group, though powerful in structure, and furnished with the usual apparatus of strong and sharp bill and claws, and other accompaniments of predatory habits, rarely attack any animal more formidable than a mouse or ground squirrel, or in some cases a frog or other of the weaker species of reptiles."

\section{OSPREY; FISH HAWK.}

\section{Pandion haliä̈tus (L.) Sav.}

Chars. Plumage lacking aftershafts, compact, imbricated, oily, to resist water; that of the legs short and close, not forming the 
flowing tufts seen in most other genera, that of the head lengthened, acuminate; primary coverts stiff and acuminate. Feet immensely large and strong, the tarsus entirely naked, granularreticulate, the toes all of the same lengtli, unwebbed at base, very scabrous underneath, the outer versatile; claws very large, rounded underneath. Hook of the bill long; nostrils touching edge of the cere. Above, dark brown; most of the head and neck, and the under parts white, latter sometimes with a tawny shade, and streaked with brown. 2 feet long; wing, 18.00-20.00 inches; tail, 8.00-10.00.

A summer resident along the coast, common in Southern and less so in Northern New England. This large hawk, so peculiar in form and aspect, differing so widely from others in technical characters, and so remarkable in the nature of its food and manner of procuring it, is one of the most regularly migratory of its tribe, coming over our limits late in March and remaining until November. Its movements, in spring at least, are related to some extent to the migrations of the fish which form its exclusive diet. The manner of procuring these animals is the same as the Kingfisher's, by plunging down from on high, but the quarry is seized with the talons, of course, not with the beak. The piscatorial habits of this bird restrict its residence to the coast and the larger inland waters. Its numbers are uncertain in different localities to all appearance equally eligible, and in some places appear to have diminished of late years from some unassignable cause. Speaking of Massachusetts, Mr. Allen has lately said that the Fish Hawk formerly bred in the State, but now probably nests there very rarely if at all; and Mr. Minot's remarks on the subject are to like effect. Our advices from Connecticut are the most explicit and interesting of any we possess. "Mr. W. W. Coe informs me," writes Mr. 
Merriam, "that Fish Hawks do not breed so far up the Connecticut River as Middletown and Portland, but are common at its mouth (about Saybrook), and that he has taken their nests, along the Sound, all the way from

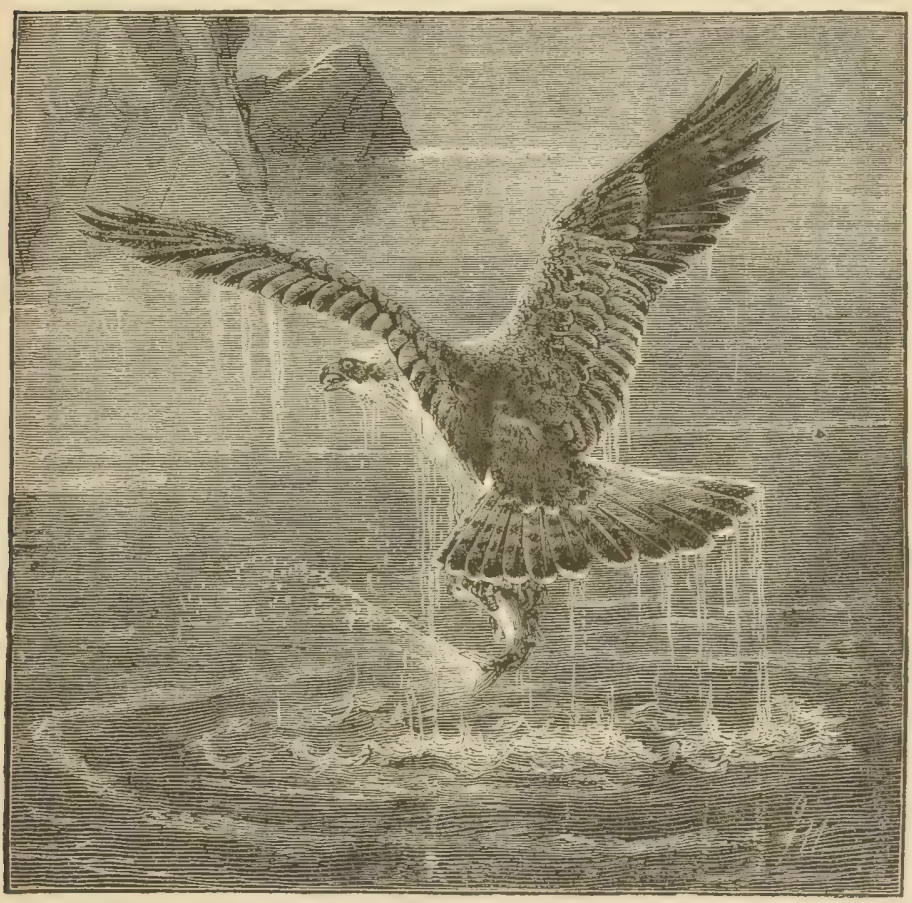

FIG. 25. - FISH HaWK.

Saybrook to New London. Immense numbers of them breed regularly at Plumb Island, Conn., where I saw, last Spring, at least five hundred nests, and over a thousand birds. There is only one small piece of timber on the island, and every tree contains a Fish-Hawk's nest, or from eight to ten Night Herons' nests. There 
is quite a colony of Night Herons there. There being not trees enough for the Hawks to nest in, many of them build on the ground, and some lay their eggs in the sand. They occupy the same nest for years, adding a little to it each season, till some of them, that were originally placed flat on the ground, had become so large that I could not look into them; they were seven feet high and measured six or eight feet across the top! On the $4^{\text {th }}$ of June I found both young birds and fresh eggs in some of the nests. The Crow Blackbirds had built their nests in among the large sticks of the Fish Hawk's nests, there being often four or five of the former placed about the sides of one of the latter." (B. Conn., I877, p. 89.)

The eggs of the Fish Hawk run through all the varieties of coloration usual in this family, from white to creamy, tawny, and reddish ground color, with a few pale brown markings or very boldly blotched with the richest shades of sienna, burnt umber, bistre and sepia. There is usually a great deal of reddish in the spotting as well as the ground color, and the "mahogany" samples make very handsome objects. The size is very variable : a specimen before us measures an inch and a half in the conjugate by two and three-quarters through the major axis.

\section{GOLDEN EAGLE.}

\section{Aquila chrysaetus (L.) Culv.}

Chars. Tarsus completely feathered. Dark brown with a purplish gloss; lanceolate feathers of head and neck, golden-brown; quills blackish; in the young, tail white, with a broad terminal black zone. About 3 feet long; wing upwards of 2 feet; tail a 
foot or more. North America, rather northerly, in winter south ordinarily to about $35^{\circ}$.

This great bird is celebrated on a principle well elucidated by Mr. Minot, who says: "Size has always a fascination for the world. The young collector prizes a hawk's egg more than that of the rarest warbler. The egg is big, the bird that lays it is big, the nest in which it was laid is big, the tree in which the nest was built is big, and the wood in which the tree grows is big." And so were the exploits of Jack with the bean-stalk. But the Golden Eagle is simply a hawk of unusual dimensions, little distinguished from the Rough-legged Buzzard except in size. It is of infrequent and irregular occurrence throughout New England, nesting anywhere that offers suitable crags for the location of its eyrie, and for the rest roaming about for food like any other bird of prey.

In Mr. Allen's report of 1878 , the cases recorded from Massachusetts are Monson, November, I864; Deerfield, December I4, I865; Westfield, three specimens, 1866; and Fairhaven, November 21, I873. "Dr. Wm. Wood has seen them near Hartford, Connecticut; while in that same State specimens have been taken by Mr. J. N. Clark, Saybrook; and by Mr. Henry Flint, at Deep River. Mr. Hiram Cutting informs us that it is not a scarce bird in Vermont, where he has found its nest, and several times secured the young. Dr. Coues has given the following description of the eggs :- "Dr. Brewer gives it as breeding in the mountainous portions of Maine, New Hampshire, Vermont, and New York, particularly instancing a nest at Franconia, New Hampshire, which was resorted to for several successive years. But its nidification is usually in such inaccessible situations, even when not in the most remote and unin- 
habitable regions, that its eggs were for a long time special desiderata. Even in 1857 , Dr. Brewer had no American specimens for description. I have, therefore, more pleasure in describing them, from no less than a dozen examples now in the Smithsonian, where, through the liberality marking the attitude of that institution toward students of science, I have been able to examine them. The eggs are almost spherical, the degree of prolation being slight, and there being usually no appreciable difference in the shape of the opposite ends. Four selected specimens measure, respectively, 2.65 by $2.15 ; 2.90$ by $2.40 ; 3.00$ by $2.35 ; 3$. 10 by 2.25 - figures illustrating both the difference in absolute size and the variation in shape. None are so large as the one said by Audubon to have been 3.50 by 2.50 ; but I can readily believe that such dimensions are sometimes reached. Among the twelve, only one is white and unmarked; this closely resembles a Bald Eagle's. The rest are whitish (white, shaded just perceptibly with neutral tint), variously spotted and splashed, without the slightest approach to uniformity in the size, number, or pattern of the markings. The color ranges from "bloody-brown" or rich sienna, to bistre and umber. There are many other spots, more or less obscure, and all apparently below the surface, showing grayish, drab, purplish, and neutral tint, by overlaying of the whitish calcareous matter in different thicknesses. Most of the markings are sharp-edged and distinct, but others shade off gradually, while many are confluent, making irregular patches. As a rule they are pretty evenly distributed, but in some specimens are chiefly gathered about one or the other end, where the coloration consequently becomes confluent." 


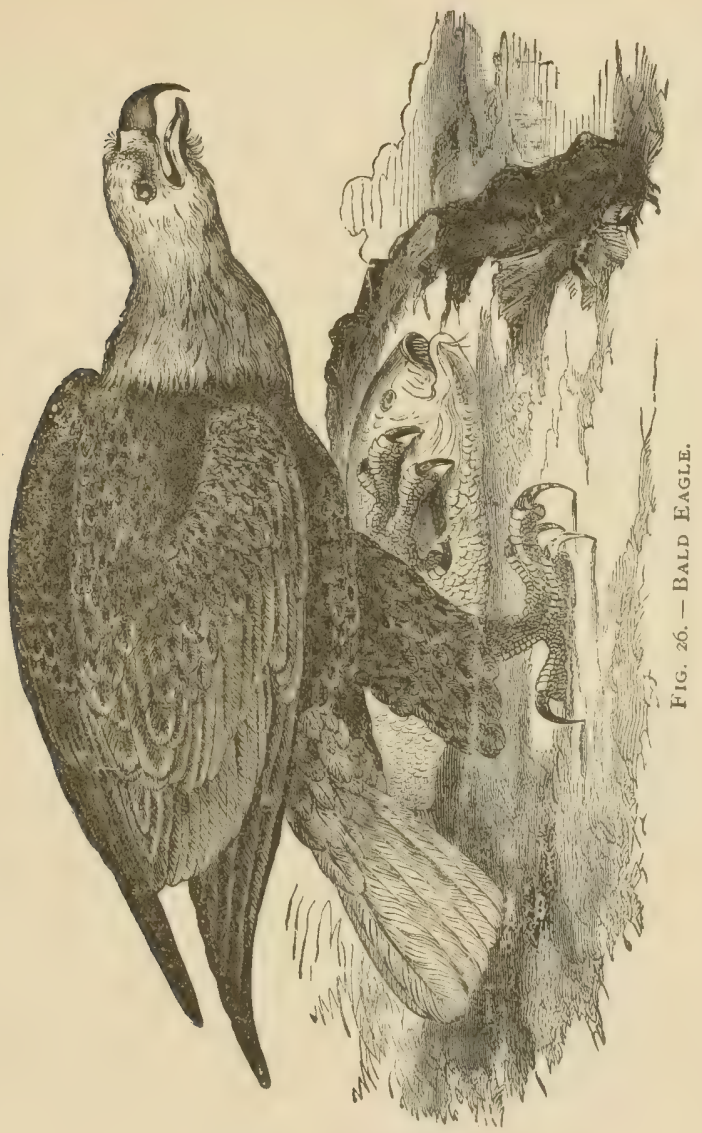

BALD EAGLE.

Haliä̈tus leucocephalus (L.) Sav.

Chars. Tarsus naked. Dark brown; head and tail white after the third year; before this, these parts like the rest of the plumage. About the size of the last species. Immature birds average larger than the adults; the famous "Bird of Washington" is a 
case in point. North America, common; piscivorous; a piratical parasite of the osprey; otherwise notorious as the emblem of the Republic. From the circumstance that several years (at least three) are required for the gaining of the perfect plumage, when the head and tail are entirely white, it follows that "Gray Eagles" and "Birds of Washington" are the more frequently met with. Those who, unpractised in ornithology, may be puzzled by accounts of numerous different kinds of Eagles, may be relieved to know that only two species have ever been found in the United States. In any plumage they may instantly be recognized by the legs - feathered to the toes in Aquila chrysaëtus, naked on the whole shank in Haliaëtus leucocephalus.

The Bald Eagle appears to have decreased in numbers of late years, to judge by comparison of earlier with more recent notices of its occurrence. Still it is to be called no uncommon bird, of general dispersion along the coast and the larger water courses, nesting wherever a convenient site for its eyrie can be found in places sufficiently secluded to give the bird a sense of security. The nest is commonly built in a tree - a huge affair, doubtless the largest structure of the kind to be found high in trees in our country, unless some of the augmented fabrics of the Fish Hawk should exceed it in bulk. The eggs are easily recognized by their size, and lack of the spotting usually observed on those of diurnal Raptores. They are commonly two in number, about three inches in length, by a scant two-and-a-half inches in breadth, and of a dull soiled white color. 


\section{FAMILY CATHARTID $E^{*}:$ AMERICAN VULTURES.}

\section{TURKEY BUZZARD.}

\section{Cathartes aura (L.) $I l l$.}

Chars. Blackish brown; quills ashy gray on their under surface ; head red; feet flesh-colored; bill white. Skin of head corrugated, sparsely beset with bristle-like feathers; plumage commencing in a circle on the neck; nostrils very large and open; tail rounded. Length, about 2 feet; extent, 6.00; wing, 2.00; tail, I.০o.

This well-known bird is entered on Dr. Coues' list of I868 as a rare or occasional visitor, chiefly in more southern portions of New England, with note of one Maine occurrence, and of its regular presence in summer near Chatham, and along the shores of Lake Sinclair, in Canada West. Mr. Merriam has later given an excellent résumé of occurrences, which we transcribe :

"A rare visitor from the south, at present, although once 'not uncommon,' according to Linsley, who further states: 'I have known it in Connecticut from a child, having at that period counted twenty in a flock in

* The American genera Sarcorhamphus, Pseudogryphus, Cathartes, and Catharista form a group of superfamily value, which may be termed CATHARTIDEs, constituting one of the primary divisions of the Raptores or Birds of Prey, the others being Gypogerani, Accipitres proper (incl. Vulturide) and Striges, though more different from the others collectively than these are from one another. $-\mathrm{C}$. 
Northford in the month of August.' Mr. Grinnell tells me that one was shot at the mouth of the Housatonic River, Conn., in June, 1875 , by C. Merwin, of Milford

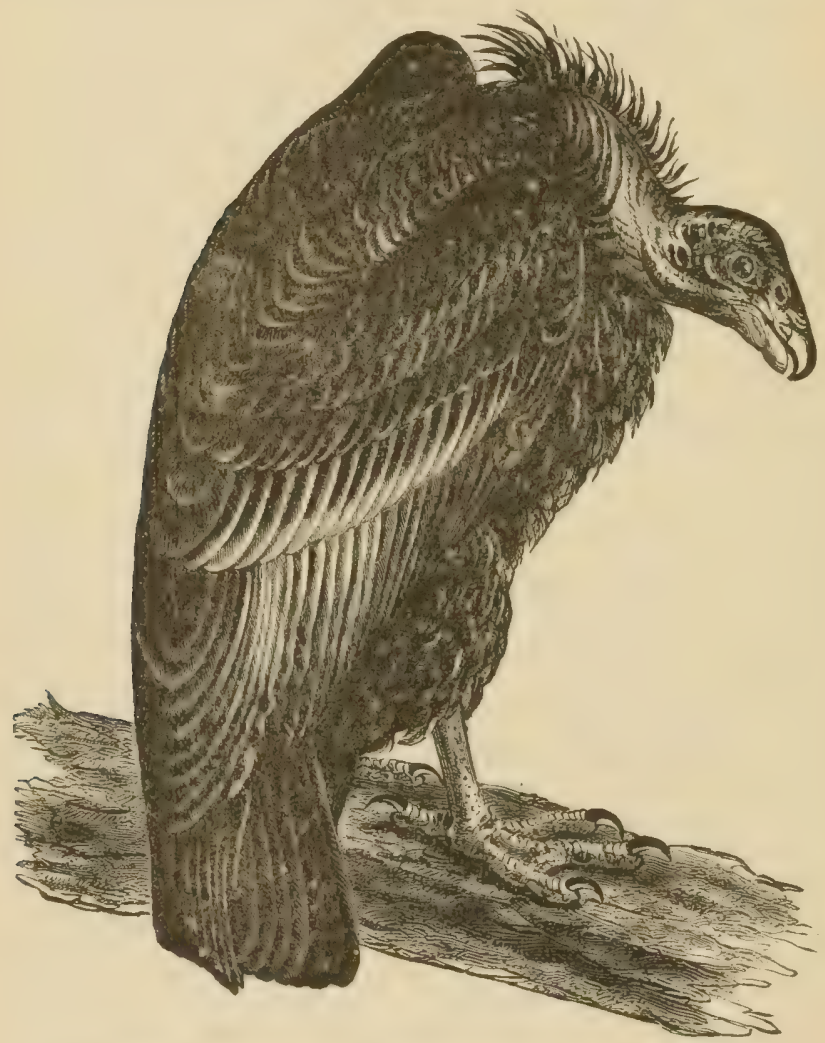

Fig. 27. - Californian Vulture, to illustrate Cathartidx.

Point. Turkey Buzzards have been observed at Saybrook, Conn., by Mr. J. N. Clark, as recorded by Purdie (Am. Nat., vii, I873, p. 693); two were taken in Massachusetts (Samuels, Cat. B. Mass., I 864, p. 3); and one 
even strayed as far to the north as Calais, Maine, where it was captured by Mr. G. A. Boardman (recorded by Prof. A. E. Verrill, Pr. Bost. Soc., ix, I862, p. 122) : Dr. Wood tells me one was seen, feeding on carrion, near East Windsor, Conn., only three years ago (1874). The Rev. J. Howard Hand writes me as follows, concerning the occurrence of Turkey Buzzards in Connecticut: 'I took one specimen at Cromwell, Conn., Sept. 23d, I874; also one at Westbrook, Conn., Oct. I6th, I875, and again, eight specimens on Oct. I8th (two days afterwards). They are not common.' Dr. Wm. O. Ayres writes me that he took one at New Haven in 1853." (B. Conn. I 877 , p. 9I.)

The columns of Forest and Stream contain several notices of New England occurrences. Mr. Everett Smith notes the capture of a specimen in a steel trap at Cumberland, Maine (iii, No. 21, p. 324). One was shot where Eutaw, Greene County, Vt., now stands (iv, No. I, p. 5). Three were seen on the island of Grand Menan, in April, 1875, and one of them was shot (J. T. C. Moses, v, No. 3, p. 36).

Mr. Maynard speaks of one seen at Waltham, Mass., in August, I 867 (Nat. Guide, I870, p. I 37) ; and Mr. Purdie's manuscript makes us aware of two later Massachusetts instances.

\section{CARRION CROW.}

\section{Catharista atrata (Bartr.) Less.}

Chars. Blackish ; quills very pale, almost whitish, on the under surface; head dusky; bill and feet grayish-yellow. Skin of head as in the last species, but plumage running up the back of neck 
to a point on the hind head; nostrils as before; tail square. Smaller than aura in linear dimensions, but a heavier bird; length about 2 feet; wing, 1.33 ; tail, 0.66 .

This species is of still less frequent occurrence than the last, its normal range in the United States not extending beyond the Carolinas. One was taken in Swampscott, Mass., November, 1850 , by Mr. S. Jillson, as given by Mr. F. W. Putnam (Pr. Essex Inst., i, I 856, p. 223). Another at Gloucester, Mass., Sept. 28, I863, which Mr. J. A. Allen cites (ibid. iv, I864, p. 81), as he does the capture of one and the observation of several others at Hudson (Am. Nat., iii, I870, p. 646). Mr. G. A. Boardman speaks of one killed at Calais, Maine (Am. Nat., iii, 1869, p. 498); and Mr. Ruthven Deane gives another Maine record (Campobello, about August, 1879, Bull. Nutt. Club, v, I880, p. 63). These are the authentic cases which have come to our knowledge: for a dubious Connecticut record, see Merriam, B. Conn., I877, p. 93 . 


\section{FAMILY COLUMBID $A$ : PIGEONS.}

\section{$\rightarrow \infty$ \\ PASSENGER PIGEON: WILD PIGEON.}

Ectopistes migratorius (L.) Sw.

Chars. Tail, 12-feathered, long and wedge-shaped; outer tailfeathers black, white and chestnut. Neck with metallic iridescence. Wing-coverts spotted with black. Male with the under parts pale purplish-red, fading behind, the sides grayish-blue like the upper parts. Female and young lacking the rich color of the breast, which is grayish, more like the upper parts. Bill, black. Eyes and feet, red. Length, about I6.00; wing, 8.00-9.00; tail little less.

Comparatively few of the descendants of myriads which in former generations of passenger pigeons darkened the air in New England are left to us now, though thousands still appear among us during the migrations, and some of them still construct the openwork platforms of twigs, through the interstices of which you may from below observe the snowy white egg or pair of eggs entrusted to these frail receptacles. Civilization has pushed the Pigeons before it, by depriving them to a great extent of the formerly inexhaustible store of mast they enjoyed, for which the fields of buckwheat or other cultivated grains are no adequate substitute. The greatest flights and roosts of Pigeons we now hear of are in the Northwestern States, - say the upper Mississippi Valley at large-where the numbers of the birds are still prodigious, furnishing no inconsiderable commercial item, as well as the usual substi- 
tutes for domestic pigeons in those contests of skill between sportsmen which our most prominently misguided misanthrope, Mr. Henry Bergh, has so long vainly essayed to suppress. The works of sundry authors who treat of Pigeons contain a large store of eligible reading matter on the subject of this Pigeon, which the limitations of our own treatise forbid us to transcribe, or even reproduce in substance; and we have no new information to offer in its stead.

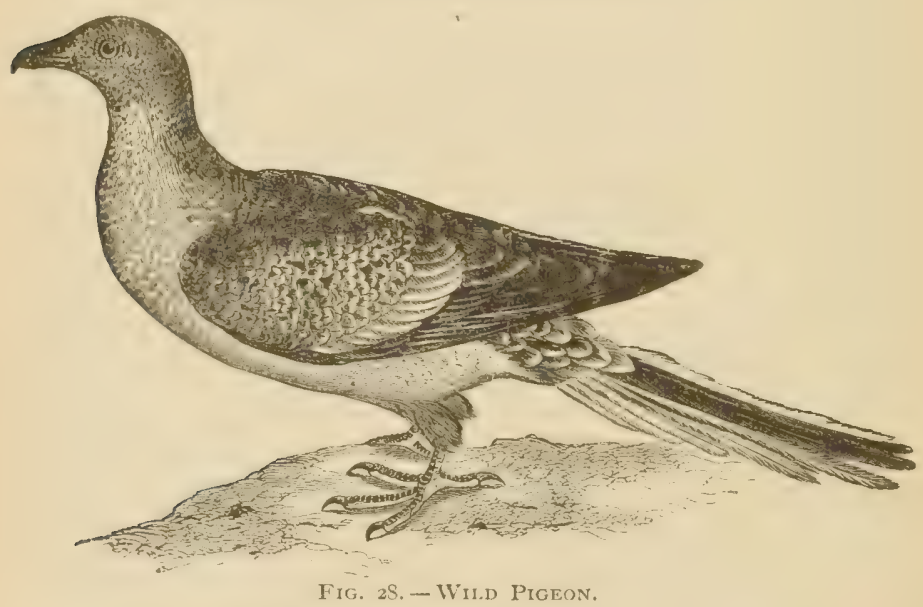

The eggs are one or two in number, pure white in color, of elliptical shape, measuring about 1.50 by 1 . IO, and are laid from April to June.

\section{WILD DOVE: MOURNING DOVE.}

\section{Zenaidura carolinensis (L.) Bp.}

Chars. Tail, I4-feathered, long and wedge-shaped, colored much like that of the Wild Pigeon, but lacking chestnut on the outer 
quills. General coloration and sexual differences much the same as in the Wild Pigeon. A velvety-black spot on the side of the head, and others on the wings, the former wanting in the Pigeon. Much smaller. Length, about 12.00 ; extent, 17.00; wing, 5.50-6.00; tail about the same.

This is a common summer resident with us, occasionally remaining through the winter, as the Wild Pigeon also sometimes does. Though often seen in companies of some extent, it is not particularly gregarious, and is generally dispersed in pairs or singly through the woods

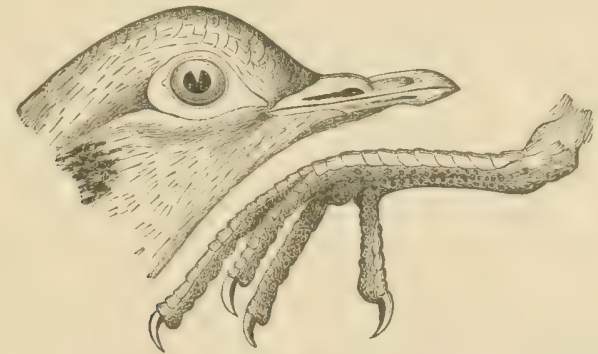

Fig. 29. - Head and Foot of Motrning Dove. Natural size.

and fields. In the autumn, however, similarity of tastes and needs generally brings many individuals together at eligible feeding grounds. It is naturally a gentle and conficling bird, but is subject to such persecution from the gunners that it is usually considered wild and shy. In portions of the country where it is seldom molested, few birds are less timid in the presence of man. During the breeding season, generally May in New England, the woods resound with the cooing of the ardent and affectionate creatures; but at other seasons the Dove is a remarkably silent bird. The eggs are usually two in number, pure white, elliptical, measuring I. Io by 0.85. The nest is placed indifferently upon a tree or bush, 
stump or log, or even on the ground - oftenest in the fork of some branch at no great elevation; it is always slight and frail, open-worked of twigs, with little or no softer material. The arrivals are mostly during the latter part of April, and the pairing and cooing begin as soon as a residence is selected. The greater number depart in October, only hardy loiterers remaining during the inclement season. The migrations are thus more orderly and regular than the movements of the Wild Pigeon, which wanders with such wayward and irresistible impulse in search of food. At the same time, it cannot be denied that in New England the distribution of the species is quite local, the birds being not uncommon in places where the food they prefer is most plentiful and accessible, yet scarcely known in neighboring localities. They are extremely fond of buckwheat; and regions where the grain is cultivated always furnish Doves in season. The same restriction and partial distribution occurs in the arid regions of the southwestern territories, but for a different reason - the scarcity of water. In Arizona, for example, there is no water-hole in all that parched land without its Doves, though the birds will scarcely be seen in the intervening desert reaches. Most of the Arizona "rivers" have no water in them; and in that extraordinary country, where everything goes by contraries, the sight of a Dove is a surer sign of water than the site of a stream. The Dove there shows the opposite character it acquired in the days of Noah, as a herald of dry land. 


\section{FAMILY MELEAGRIDIDA: TURKEYS.}

NOTE ON THE WILD TURKEY.

There is no longer a doubt of the extirpation of this noble bird in New England. I have been at some pains to examine the records, and am satisfied of its entire extinction. A few words will, however, be pertinent to the history of the case.

The bird was formerly abundant in southern New England, as attested by all the earlier writings which touch upon the case. Their number must have been so much thinned out during the last century that the period of their plenty ceased about the beginning of the present, if not somewhat earlier.

The Rev. Mr. Linsley's record is especially noteworthy. Writing in 1843 , he says: "The last Wild Turkey that I have known in New England was taken by a relative of mine, about thirty years since, on Totoket Mountain, in Northford. It was overtaken in a deep snow, and thereby outrun." (Am. Jour. Sci., xliv, I843, p. 264.)

About the same time Zadock Thompson represented that Turkeys continued to visit and breed upon the mountains in southern parts of Vermont. (Hist. Vermont, I 842 , p. IOI.)

The Turkey appears to have lingered longest in the mountainous parts of Massachusetts. Though Prof. Emmons considered it nearly extinct in that State in I 833 , it was said by Prof. Hitchcock to be at that time "frequently" found on Mt. Holyoke (Rep. Geol. etc., Mass., 1833, p. 549). 
Mr. Merriam's model paper gives us in this, as in so many other cases, very valuable information. "Professor W. D. Whitney once mounted a fine specimen of the Wild Turkey, killed on Mt. Tom, Mass., Nov. Ist, I 847. It may now be seen in the beautiful case of birds given by Prof. Whitney to the Peabody Museum of Yale College, and is of particular value as being, in all probability, the last of its race seen in that State." (Rev. B. Conn., I877, p. 99.)

Dr. Brewer retains it in his list of 1875 , with the remar? : "resident, probably extinct." (Pr. Bost. Soc. Nat. Hist., xvii, I 875, p. 445.)

The highest authority now writing upon the Birds of New England - I mean Mr. Allen, of course - agrees to the substance of the statements here given, in the latest note he has left upon the subject. "Well known," he says, "to have been a common species in southern New England for a long time subsequent to the first settlement of this part of the country (see Bull. Nutt. Orn. Club, i, Sept., I876, p. 55), but long since ceased to exist here in a wild state." (Bull. Essex Inst., x, I878, p. 3I.) 


\section{FAMILY TETRAONID $Æ$ : GROUSE.}

\section{WILLOW PTARMIGAN.}

\section{Lagopus albus (Gm.) Aud.}

Chars. Legs feathered to the claws. In winter, pure white, tail black, two middle feathers excepted; bill black. Summer, the foreparts rich chestnut or orange-brown, variegated with blackish, the upper parts and sides barred with blackish, tawny and white; most other parts white. Length, I 5.00 ; extent, 24.00; wing, 7.75 ; tail, 5.10.

The New England record of the Ptarmigan is not free from suspicion, and we allow the species a place with some misgiving. It doubtless occurs, however, in Northern Maine, as it certainly does in Lewis County, N. Y. Prof. Verrill says : "Northern Maine, in winter, rare" (Pr. Essex Inst., iii, I862, p. I 57). The Massachusetts (Manchester, Essex Co., May, I859) specimen, recorded by Dr. Coules (ibid., v, I 868, p. 289) as extant in the Museum of the Essex Institute, was supposed to have been brought alive from Labrador and escaped, as stated in that connection. Mr. G. A. Boardman, of Calais, Me., to whom we wrote for information, assures us that he has been unable to satisfy himself that the Ptarmigan has ever been known to occur in New England. With this explanation, which we trust will not leave us liable to the charge of improperly augmenting our list of New England birds, and calling special attention to the insufficiency of the accredited records, we introduce the species hypothetically. 


\section{PRAIRIE HEN.}

\section{Cupidonia cupido (L.) Bd.}

Char. Larger than the Ruffed Grouse. Tail very short. Legs feathered to the toes. A tuft of long pointed feathers on each side of the neck, beneath which is a naked space capable of great inflation. Plumage of the under parts barred transversely.

Writing in I868, Dr. Coues speaks of the Prairie Fowl in the following terms: "This species is still known to reside in certain localities in New England, though much less numerous than formerly, and doubtless destined shortly to become extinct." He cites Martha's Vineyard and Naushon, as well as Long Island, upon the testimony of previous writers (Pr. Essex Inst., v, I868, p. 287). Mr. Allen had before stated it to be "nearly extinct in Massachusetts." A few, he said, still occasionally visit the southeastern part of the State from Long Island, where the bird still lived at that date (Pr. Essex Inst., iv, I864, p. 85). In I839, according to the Rev. W. B. O. Peabody, the only place where it was still found was Martha's Vineyard and one small island near it, though once very common in Massachusetts (Rep. B. Mass., I839, p. 355). Mr. Merriam's advices are as follows:-

"The Prairie Chicken, or Pinnated Grouse, Cupidonia cupido (Linné) B., was formerly a resident of New England, but, like the Wild Turkey, was exterminated many years ago - at least so far as the mainland is concerned, for it is said that a few still exist on some of the islands south of Cape Cod (Naushon, for example, and perhaps Martha's Vineyard). However, it is pretty certain that many years have elapsed since the last 'wild chicken' 
was seen in Connecticut, for even Linsley, in I 842, gave it as a bird of the past. Nuttall, ten years earlier (in I 832), said that they were still met with 'on the brushy

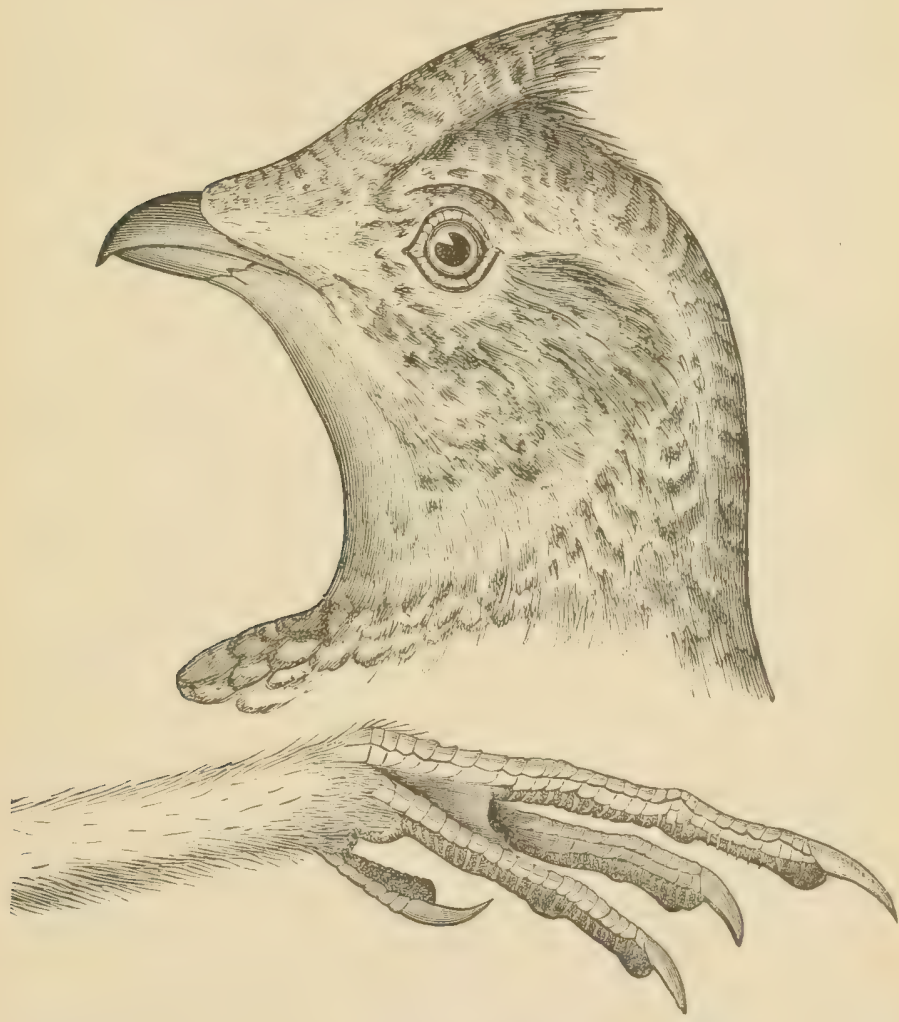

Figs. 3o, 31. - Head and Foot of Prairie Hen. Natural size.

plains of Long Island, and in similar shmbby barrens in Westford, Connecticut'" (Rev. B. Conn, I877, p. IOI).

In Mr. Allen's List of 1878 (Bull. Essex Inst., x, p. 22) the statement is made of the former commonness of the 
bird in Massachusetts, and of its extirpation long since from all portions except Martha's Vineyard, where a few " are said" still to exist. At p. 37 of the same admirable catalogue, under head of "Introduced undomesticated species," the writer speaks of their introduction at different times in Barnstable County, adding that "none of them or their descendants are certainly known to still exist there."

Viewing the "perhaps" and "it is said" of the later records, it is gratifying to be able to pronounce without reserve of the preservation of this fine game bird in our country up to the present time. According to Mr. Purdie, quite a little colony still lives on Martha's Vineyard, Mass., the last New England stronghold of the species. (See Maynard's Birds of Eastern North America, part xiv, July, I880, p. 351.)

It would seem perfectly feasible to stock suitable localities with Prairie Hens, which, if protected by stringent law for a period of years, might then resume the role of the fine game bird which the species formerly took in New England.

CANADA GROUSE, OR SPRUCE PARTRIDGE. Canace canadensis (L.) Reich.

Chars. Male: Tail of sixteen feathers, rounded, black, with a broad orange-brown terminal bar. No obviously peculiar feathers on the side of the neck. Legs feathered to between the toes. The usual naked, colored strip of skin over the eye. Prevailing color black, with numerous sharp white bars and spots on the under parts, and on the upper parts finely waved with gray or tawny. Length, about 16.00; wing, 7.00; tail, 
5.50. Female: nowhere continuously black, but much variegated with brown, tawny and white; the same orange colored tail-bar, not so well defined. In size, rather less than the male.

The normal limit of dispersion of the Canada Grouse southward divides the Canadian from the Alleghanian Fauna, enabling us to draw the line between the two with greater exactitude, perhaps, than that afforded by the distribution of any other of our birds. The fine creature resides in all the evergreen wooded, and especially in the swampy, parts of Northern New England, and is not a migratory species. It is said to be common at Umbagog, in Maine, and to be

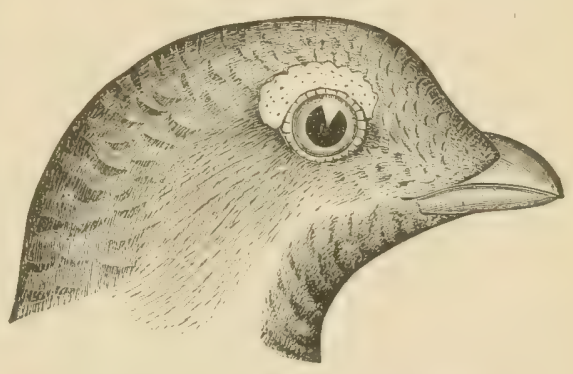

Fig. 32. - Head of Canada Grouse. Natural size. ordinarily limited southward by the White Mountain range. The few instances in which this Grouse has been shown to occur beyond the region indicated must be regarded as irregular, if not wholly accidental. Mr. Allen, very properly, it seems to us, considers the two reported Massachusetts captures as accidental. One of these was in the hemlock woods of Gloucester, in September, I85 I ; the other in Roxbury, about I865 (Am. Nat., iii, 1870, p. 636; and Bull. Essex Inst., x, 1878, p. 22). Farther south, the Spruce Grouse is unknown, even as a straggler.

Like others of its family, this Grouse nests on the ground, usually in swampy, secluded localities. The eggs are laid in the latter part of May, and young may 
be found by the middle of June. When surprised with her brood, the parent bird is very courageous in their defence, even attacking the intruder who threatens the peace. The nest is made of twigs, leaves, grasses, and moss, and much art is often displayed to conceal it. The eggs, to the number of a dozen or more, are less elongate than those of some Grouse, broader at the butt, and more pointed at the other end; thus approaching the shape characteristic of Partridge eggs, and being like those of Ptarmigan in size and form. The following measurements of selected examples from a large series show the size, shape and range of variation: 1.70 by $1.25 ; 1.70$ by $1.20 ; 1.65$ by $1.25 ; 1.65$ by 1.15 . High in the oviduct the egg is creamy-white. This color is washed over to a varying degree of intensity with rich chestnut-brown - generally a pale "creamy" brown - and is further dotted, spotted, sometimes even splashed and blotched, with a very dark, heavy shade of the same color, the markings being numerous, strong and bold, of no determinate shape, and very irregularly distributed. These markings are only an intensification, in spots, of the ground color, but are very heavy, and show a decided approach to the peculiarly dark and heavy pattern of Ptarmigan eggs.

\section{RUFFED GROUSE, OR PARTRIDGE.}

Bonasa umbella (L.) Stcpli.

Chars. Tarsi incompletely feathered. Head crested. Tail large and fan-shaped, usually of 18 broad obtuse feathers. A conspicuous ruffle of lengthened feathers on each side of the neck. Tail gray or brown, with broad subterminal black zone, and 
finely barred or vermiculated with black. Feathers of the ruff glossy dark brown or black. Primaries fuscous, marked with whitish on the outer webs. Under parts whitish or pale tawny, variously marked with brown, chiefly in bars, the throat chiefiy immaculate; upper parts intimately blended olive, brown, gray black and white, the general effect being black and white or tawny spots on a reddish-brown ground. Varies interminably in the precise tone and pattern of the markings. Female resembling the male: the ruff less developed and not so intensely colored. Length, I6.00-I8.00; extent, about 22.00; wing and tail, each $6.00-7.00$; tarsus, about 1.75 ; middle toe and claw, about 2.00 .

This fine bird is the most abundant and generously distributed kind of Grouse in New England, inhabiting wooded and swampy portions of our country, without . regard to special geographical distribution. In fact, Grouse of this species, in one or another of its several varieties, occur in nearly all the woodland of North America, and are very closely related to the Hazel Grouse of Europe, Bonasa betulina. The characters of any Bonasa, or "ruffled" Grouse, are so strongly marked that there should be no difficulty in recognizing it, and no confusion with species of Canace, still less with any of the Partridges proper. Whatever the special tone and pattern of coloration of these birds, the soft, silky black frill on the neck, and the amply fan-shaped tail. should be distinctive at a glance. Yet great uncertainty does find its way into the minds of many who have ample means of judging, as to the character of this bird. Much of this is traceable to the vague use of the name "Partridge" to designate birds not only specifically but also generally distinct from one another. Both the Canace canadensis and Bonasa umbella are true Grouse, as witnesscd by the feathering of the shank and nostrils; but in New England they are both often called 
"Partridges," the real Partridge of the United States being termed a Quail. In the Southern States the case is still further complicated by calling Bonasa a "Pheasant." This confusion in nomenclature is an inheritance from the earliest English settlers of our country, who naturally called any bird new to them by a name suggested by its real or fancied resemblance to some European species with which they were familiar. Most of the error resulting from such practice ceases in the course

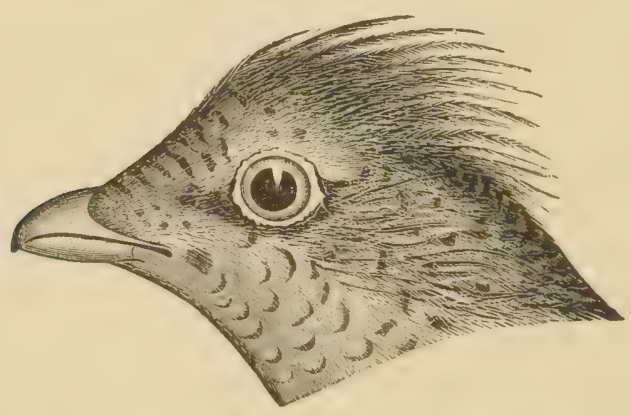

Fis. 33.- Head of Ruffed Grouse. Natural size.

of time to be mischievous, or even disappears, as in the case of our Robin, Turdus migratorius, which familiar bird no one confounds with the European "Robin Redbreast," the very existence of which is little more than a memory of nursery tales with most persons in this country. The matter stands very differently, however, with our game birds of the gallinaceous tribe, the confusion of nomenclature being so hopeless that naturalists, after repeatedly returning to the charge, generally give up in dispair of doing away with it.

The most remarkable trait in the disposition of the Ruffer Grouse is that which confirms the bird in the 
habit of making the noise called "drumming." Here again not only sportsmen but the best naturalists are singularly discordant in the explanation they give of the curious feat. Mounted upon a fallen log or stump, the Grouse puffs out its feathers, spreads its tail, raises its crest, and opens its " umbrellas;" and then, with its head drawn close to the body, struts stiffly and consequentially about. So far, the performance tallies with what every one has seen when a Turkey-cock displays what a superb masculine creature it takes itself to be, and probably all of our Grouse exploit in a similar manner, though each one after a fashion of its own, when inflated with erotic vanity. Just as the Turkey-cock "gobbles" at such times, so do other Gallina give vent to the most uncouth sounds, the volume of which is so vastly increased, in the cases of many of the Grouse, by the great air-sacs which are developed beneath the skin of the neck, that the hollow reveberations may be heard at a great distance. The noise which proceeds from the Ruffed Grouse, however, is not vocal but instrumental, and that it results from amazingly rapid vibration of the wings is certain. For one who is near enough during the performance may see that the wings move so rapidly that the strokes clissolve to the eye in a haze on each side of the creature, like that perceived when a Humming-bird is hovering before a flower. But just how the noise is made is a question which has been confidently answered in at least four different and irreconcilable ways. First, say some, the bird beats its wings against the log or stump upon which it stands. Secondly, it strikes the outside of the wings together over its back. Thirdly, it claps its wings against the sides of its body, like a rooster about to crow. Fourthly, it 
beats the air. Those who are interested to follow up the subject may refer to Dr. Coues' Birds of the Northwest, where the views of many writers are collated and compared, the author coming to the conclusion that the last explanation here given is the correct one. No one who has heard the whirring of the tiny Humming-bird, or the "booming" of the night-hawk, and witnessed the extraordinary aërial antics of the latter bird at the moment the sound is produced, can doubt that the rapid movement of feathers in the air may make so much noise that there is no difficulty in explaining the rumbling sounds that come from the Ruffed Grouse in the same way, contrary as it is to the familiar clapping of the wings of the barn-yard fowl. The bird's "music" would, therefore, appear to be literally that of a wind instrument - unlike the vocalization of most Grouse, and also different from the playing upon a stringed instrument which results in the stridulation of many insects, which literally fiddle upon themselves by scraping together different parts of the body. As to the reason why the Grouse indulges in such performances, it may be said that it is primarily a manifestation of sexual vigor and desire, universally admired by the fair of the opposite sex, like all other masculine demonstrations, from the most delicately suggestive to the most effectually operative. But the Grouse drums both in and out of love; so that it seems to be done often for his own amusement, or to work off his animal spirits. The excessive muscular motility induced when the bird has his spasms may be imagined when we reflect that the great stiff wings move up and down too rapidly to be perceived by the human eye, and that millions of cubic yards of air are set in vibration audible to our dull ears. 
In the greater part of May, and early in June, you may find the nest in the woods, oftenest in low swampy places or tangled undergrowth, at the foot of a bush or stump, or alongside of a prostrate log. It is a rucle domicile, - merely a slight hollow in the ground, lined with some leaves or a little grass or moss. The eggs are characteristic of the species, differing both in form and color from those of most Grouse; they approach the pyriform contour - very broad and blunt at one end, and sharp at the other-usually seen in Partridge eggs, and also lack the heaviness of coloring common to most Grouse's eggs, and at a maximum in those of Ptarmigan. The eggs are creamy-colored, varying from pale, creamy white to rich creamy-brown; they may be immaculate, or scarcely dotted in fine points only, though they sometimes have small round spots of pale chocolatebrown set in amongst countless minute dots. In number they range from 8 or io to a dozen or more, according to the age and vigor of the parents or other circumstances; and in size they measure about one and two thirds by one and a fourth inches. They are said to be deposited at intervals of twenty-four hours till the set is completed, and to hatch in about eighteen days from the beginning of incubation. The young begin to ramble about as soon as they are hatched, like little chickens, and in fact like all the "prococial" Gallince and Grallatorcs; the mother leads them in paths of peace and pleasantness, as well as she can judge, where food is most abundant, and shelter from enemies is most likely to be secured the thickest cover of tangle, where the ground is springy, being the favorite resort. She is motherly in the extreme; her maternal devotion is not seldom proven by the vigilance and address she displays to get 
her little ones hidden from threatened danger before she thinks of her own safety, and her courage in such an emergency will even lead her to risk her own life in their defence. In our country, as well as generally in northern portions of the range of this Grouse, one brood seems to be all that the birds can successfully produce and rear as a rule; for the chicks grow tardily, and are not off their parents' hands till well toward the waning summer; so that the broods of callow young found unusually late in the season are probably to be accounted for by some accident to the happy course of domestic affairs early in the season.

The flesh of this bird is white, and good for the table. The Grouse ranks high as a game bird in the estimation of some sportsmen, but its pursuit is attended with great uncertainty and difficulty, except in localities where the birds are very abundant. It is very fatiguing to follow them in their fastnesses of swamp and tangle; they behave before a dog with more regard to their own ideas than to the wishes of their would-be destroyers; they get up with startling suddenness, and fly off with amazing celerity; altogether their instinct of self-preservation is "functionally developed" to a high rate of efficiency, as a physiologist might say, and they would be still more numerous did not these very qualities stimulate the ardor of the sportsman to their ceaseless persecution. Being robust, hardy birds, much more so than Partridges, they stand our hard winters well, probably very seldom freezing to death or getting snowed up to their destruction, accidents to which the smaller and more delicate Partridges are frequently exposed in our latitudes. Having an extensive and varied bill of fare, in numerous small fruits, both hard and soft, in season, 
in numberless insects during a part of the year, and in various leaves and buds at another, life may be quite worth living for these brave, self-reliant and judicious creatures. Let us imagine them to be resigned to the inevitable having to live, even though they be neither contented nor happy; and as finding in that necessity the logical refuge from the doubt raised by many halffledged philosophers whether life be worth living.

\section{THE AMERICAN PARTRIDGE, QUAIL, OR BOB-WHITE.}

\section{Ortyx Virginiana (L.) $B p$.}

Chars. Tarsi and nasal fossæ naked. A small erectable crest on the head. No peculiar feathers on side of neck. Throat of male white, of female tawny. Upper parts blended brownishred and gray; lower parts whitish, with many sharp dark marks, especially on the breast and about the white on the throat. Length about 9.00 ; extent, I4.50 ; wing, 4.50 : tail, 2.75.

The well-known and abundant Bob-white, called "Quail," in New England, where the Ruffed Grouse is called "Partridge," and named "Partridge " further south, wherever the Ruffed Grouse is called "Pheasant," - this paragon of good qualities, from the sportsman's standpoint, has been ascribed in general terms to all New England, as by Dr. Brewer for example, but certainly upon hasty conclusions. Though, owing to its habit of colonizing particular spots beyond its general range, and to some extent to its habit of moving back and forth from caprice or according to vicissitudes of the weather, it is difficult to trace the exact limit of its northward dispersion, 
the bird may be said to inhabit at present only the three southern New England States. That it overlaps at times, or in particular localities, into the other three, is doubtless a fact. It is a true component of the Alleghanian and other more southern Faunæ, its range being complementary to that of the Spruce Grouse, Canace conadensis: and the scattering coveys in southern Maine, New Hampshire and Vermont are rather evidence of this fact than of the assumption that the bird should be considered native to New England at large. The range appears, moreover, to have been arti-

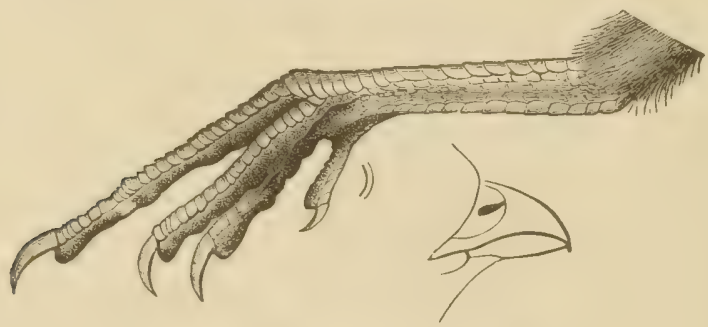

Fig. 34. - Bill and Foot of Quail.

ficially restricted of late years as a consequence of the persecution to which the birds are always subjected. In fine, Massachusetts is practically the limit of the Bobwhite, and it is not found to be numerously or evenly distributed throughout that State.

A contributor to Minot's "Birds of New England" has prepared the following agreeable sketch: "The Quail are abundant in the three Southern States of New England, except in the colder and more hilly portions. They are not found much to the east or north of Boston, in the neighborhood of which, however, they are resident throughout the year. Our observations on 
them naturally begin at that season of the year when they relinquish the habits of extreme cunning and vigilance for that of confidence in man's respect tor domestic life, that is in the early part of summer. Though among the hardiest and most active of feathered creatures, they are prudent in spring, and do not commit themselves to the risks of incubation until they have received full assurance of fitting weather. In this respect they differ from the peculiar but more venturesom e Woodcock, whose premature endeavors, founded upon the first deceptive smile of spring, to raise a

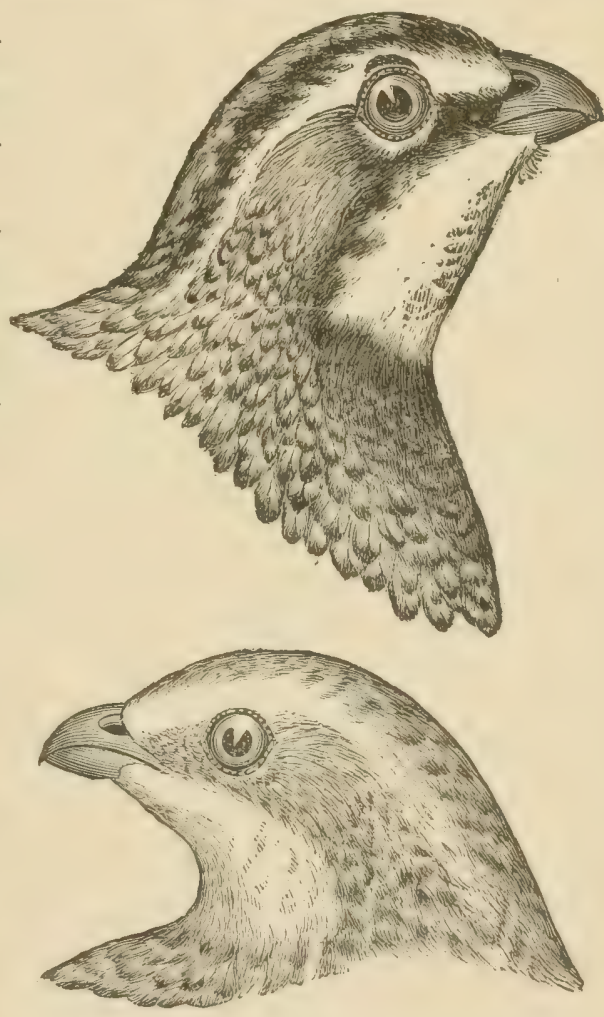

Fig. 35.-Cock ANd HeN QUaIL. Natural size. family, are often defeated by an unexpected snow-storm. The Quail do not begin until May, when they announce the fact to all their neighbors within half a mile by their loud, frank and cheery whistle, which is generally trans- 
lated into our uncouth language as 'Bob-white.' The male is not now constrained by fear, and instead of any false pricle, he has a proper sense of his own comely appearance. He knows that he is attending adequately to his own department in the great business of nature, and is entirely willing that any one should see him. He has no fear of man, but keeps an eye to the hawks, cats, and those other predatory enemies, who respect neither time, place nor season. $\mathrm{He}$ is willing to take any amount of family responsibility; nature cannot ask too much of him; he will whistle to two or three wives if necessary; and he will even accept the law of Moses, and assume the part of husband toward his brother's widow. Should his wife propose a family of fifteen instead of nine, he does not complain; and moreover, having escorted his young family about for some time, he is ready to go through with this once or even twice more. In fact, he carries his amiability and inclustry so far as often to introduce a half-grown family to the rigors of winter, so that it is not uncommon to find a covey of these little 'cheepers,' when hardly able to fly, even in November. A successful pair of Quail will often turn out twenty-five young in a season. During the period of incubation, the Quail often appear on our lawns, or on the walls and fences by the roadside. Though their bills are especially aclapted to crushing, and their crops to dissolving small grains and seeds, they are also fond of grubs, worms and other insects, and are thus useful in destroying the farmer's pests."

The eggs of the American Partridges differ much among themselves, those of some species, as the beautiful crested creatures of the southwest, being as heavily colored as those of Grouse, while others are pure white, 
ORTYX VIRGINIANA : THE QUAIL, OR BOB-TVHITE. I6I

without any markings. Bob-white's are of the latter character. They are broad and blunt at one end and sharp at the other, and measure about 1.25. by 1.OO. The nest is a mere depression in the ground, lined with a little grass or a few leaves, and usually hidden beneath the friendly shelter of overgrowing grass weeds or bushes - not seldom a heap of brushwood. The number of eggs laid is wholly indeterminate. A female may be found incubating eight or ten only; while in other cases, in which very likely more than one parent contributes some of the number, as many as two dozen have been found together.

Among the perennial conundrums propounded by persons short-sighted in respect to the laws of nature is one which touches the present bird. Quite a literature sprang up recently in the sporting papers in answer to the question, "Can Quail withhold their scent?" No one doubts that under some circumstances the best dog is unable to find a Quail by following his nose, or to detect its presence by the sense of smell. Some suppose this due to causes outside the bird, and wholly independent of the bird's intentions or actions, such as the state of the atmosphere. Others maintain that the bird can consciously, that is, intentionally and designedly, prevent the escape of its effluvium, and thus secure immunity from pursuit. The former explanation seems to be quite beside the point, and the latter to be absurd. No act of conscious volition - that is, the operation of will-power, could effect such a result, even supposing a Quail to know when it would be of advantage to retain its effluvium, and to try to do so - which supposition is itself unreasonable. The true explanation would seem to be that certain actions of the bird, instinctively ac- 
complished in the face of danger, result in the retention of the scent; the retention being, furthermore, favored or hindered by certain circumstances, such as the state of the atmosphere.

Note on the Introduction of the Messina or Migratory Quall of Europe, Cotumix dactylisonans, in New England. Of late years, hundreds of these birds, quite different generically as well as specifically from any American representatives of the Partridge family, have been imported and turned out in various parts of New England. Though they are known in some instances to have paired and bred, the result of the experiment is still doubtful, and their naturalization in New England does not appear to be an accomplished fact. Lack of space forbicls us to enter into the details of the experiment. Mr. Allen has given a summary notice (Bull. Essex Inst., x, I878, p. 36) ; and the following records may also be consulted: Forest and Stream, issues of June 28, Aug. 2, 9, 23, Sept. 6, Nov. 15, 22, 29, Dec. 6, 27, 1877; June 20, Aug. 8, 22, 1878; Jan. I, Feb. 20, Mar. 13, 20, June 19, 26, Aug. I4, 28, Oct. I6, Dec. I I, 25, I 879. 


\section{WATER BIRDS.}

\section{FAMILY CHARADRIIDA: PLOVERS.}

\section{BLACK-BELLIED PLOVER.}

Squatarola helvetica (L.) Cur.

Chars. Distinguished from all other Plovers by having a small hind toe, no trace of which is seen in the rest of the species. Plumage speckled, like that of the Golden Plover, without any of the rings and bands of color which characterize the species of Afgialites. Adult breeding plumage (rarely seen in the U. S.): Face and entire under parts, black; upper parts, variegated with black and white or ashy; tail, barred with black and white; wing quills, dusky, with large white patches. Adult winter plumage, and young: Under parts, white, more or less shaded with gray; the throat and breast speckled with dusky; upper parts speckled with blackish, white and yellowish ; rump, white, with dark bars; legs, dull bluish. Old birds changing show every gradation between the plumages given. Length, II.00I 2.00 ; extent about 23.50 ; wing, 7.25 ; tail, 3.00 ; bill, $1.00-$ I.25; tarsus, 2.00 ; middle toe, I.20.

Passing from the Land Birds, we enter now upon the no less varied and scarcely less extensive series of those feathered creatures which are seldom found except by the water's edge, or which are as much at home in the limpid element as upon its fixed shores; which, when not on the water itself, do not as a rule live in trees and 
bushes above the ground, but alight upon the earth itself. This series is collectively called "Water Birds;" the members of which, representing many families and even orders, fall in the two extensive categories of wading or grallatorial birds, and of swimming or natatorial birds, according as their organization fits them more especially for one or the other of these modes of life. The former are usually small-bodied, long-legged, and longnecked birds; the Snipes and Plovers, and the Herons and Cranes, respectively exemplify some of the leading

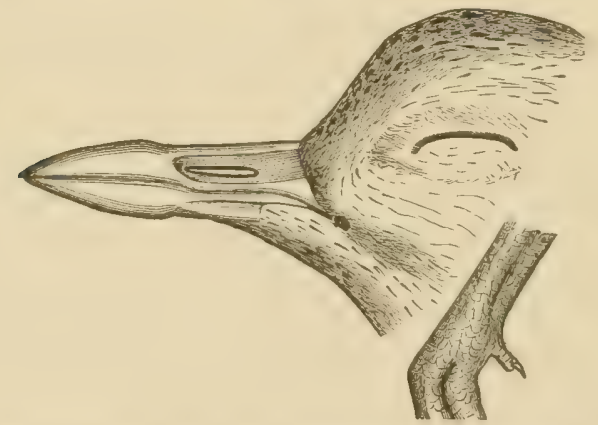

Fig. 36. - Head and Foot of Squatarola. Natural size.

families; while the thick-set, short-limbed, web-footed birds of all kinds illustrate the great variety of ways in which the natatorial plan of structure is carried out. In round numbers about two-fifths of the Bird Fauna of New England consists of water birds.

The Plovers, as a group, like the members of the closely related Snipe family, are noted for the extent and regularity of their migrations. Many species protract their mysterious journey to very high latitudes in the spring time; in the fall, when the bird-tide ebbs, they visit us again for a few weeks, and pass on south- 
ward. The majority of such birds are, therefore, vernal and autumnal migrants with us, neither nesting within our limits, nor enduring the rigors of our inhospitable season.

The Black-bellied Plover, called "Bull-head" or "Beetle-head" by the gunners, is a good illustration of these remarks. It is common during the migration, particularly coastwise, but never seen at other seasons. It arrives late in April, and remains but a short time, seeming anxious to be on its way, as if it knew what a long journey must be accomplished in order that the sudden and fleeting Arctic summer may see its brood safely on wing. Returning in the fall from these dreary hyperborean regions, it greets us early in September, and then seems in no hurry to seek other feeding grounds. For several weeks it lingers with us in flocks, both along the coast and on the uplands, before proceeding further on its long and devious pathway towards the tropics.

Eggs of this species, collected on the Arctic coast, east of Anderson River, July 4, I 864, afford the following description: Size 2. IO by I.40, to I.9O by 1.40 , in a set of four. ' Color, brownish-drab, or rather dark brownish-clay color, very thickly marked at and around the larger end, for nearly half the length of the egg, with irregularly sized and shaped spots and blotches of brownish-black, and over the rest of the surface thinly spotted with smaller marks of the same color. The larger markings around the butt are to a great extent confluent, producing an imperfect wreath. A very few paler shell markings are noted on close scrutiny. The nest was a depression of the ground on the side of a slight eminence, lined with a few dried grasses. An- 
other set of four from the same source average more elongated, the most pointed one being 2.30 long by I.45 broad; the markings are much more evenly distributed over the whole egg, are smaller, and tending to a confused, scratchy pattern, as well as rather lighter in tone. A third set of four from Franklin Bay are intermediate between the other two in these respects, though most like the first described.

\section{GOLDEN PLOVER.}

\section{Charadrius dominicus $M \ddot{u} l l$.}

Chars. Plumage of the upper parts speckled, and of the under parts in the breeding season black, as in the last described species; but much of the speckling golden yellow, and the rump and upper tail-coverts like the back; forehead and broad line over the eye to nape, white; tail-feathers grayish-brown, with imperfect white or ashy bars; axillars, gray or ashy. At other times, under parts much the same as in last species. No hind toe. Length, 10.00-I1.00; extent, 20.00 ; wing, 7.00 or less; tail, under 3.00 ; bill, 1.00 or less; tarsus, 1.65 ; middle toe and claw, r.ro.

The Golden Plover is even better known to the gunners than the last, being during the migrations more abundant and generally distributed. It has a number of local names, some of them applied both to this species and the Black-bellied Plover, by those who do not discriminate between these generically distinct birds. The general habits of the two are counterpart. The Golden Plover appears during the latter part of April, making but a flying visit, and it is then off for its favorite breeding grounds in the far north. In the return movement some birds come by the latter part of August; their 
numbers are increased in September, and all through that month, and perhaps for a few days in October, fine sport may be had. The birds at this season are fat, tender and delicious, being excelled by few in the delicate sapidity of their flesh. They are, consequently, in great demand for the market, and are incessantly pursued not only by gentlemen who are fond of shooting, but by professional pot-hunters.

The Golden Plover breeds only far northward, and is not ordinarily seen in the United States in the advanced breeding plumage above noted. It appears to have no special lines of migration, but passes over the country at large, sometimes in vast flocks, its autumnal progress being more leis-

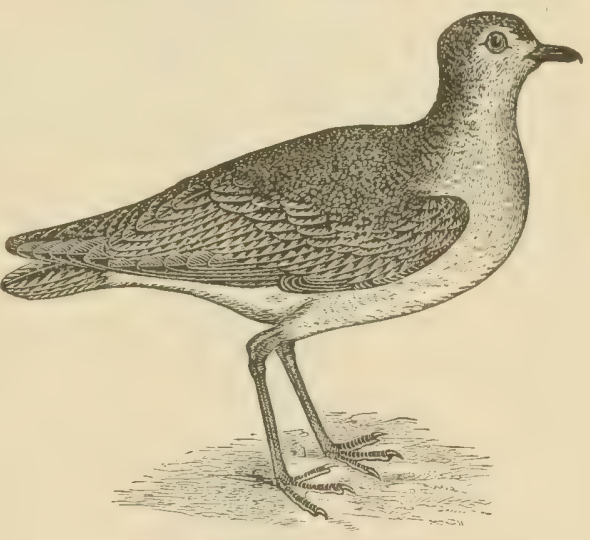

Fig. 37.-Golden Plover. urely than its advance in the spring. It reaches its breeding grounds late in May - the barren grounds of British America, and the coasts and islands of the Arctic Ocean. The eggs, as usual in this family, are oftenest four in number. They are of the ordinary pyriform shape, pointed at one end and very obtuse at the other. The following measurements may indicate extremes of variation in shape- 2.00 by 1.35 ; I.SO by I.40. They are distinguished from those of $S$. helvetica by their decided average smaller size; and though 
the general pattern of coloration is similar, the shade is not quite the same. The ground color is rather a pale, brownish-clay color, than a drab, in most specimens, although some shade quite closely into the drab of helretica. Some specimens have the ground-color extremely pale, grayish-white, nearly dead white. On all the eggs the markings are exceedingly bold, dark and numerous; it is impossible to describe adequately the endless variations in precise pattern. The average egg is heavily marked about the butt with blackish-brown, in large, irregular spots and blotches; while similar smaller spots are sparsely distributed over the rest of the surface. Sometimes markings are much lighter brown, a rich, dark sienna, and they are sometimes distributed over the whole surface with approximate uniformity, but the decided tendency is to aggregate around the butt in semi-confluent masses, or a wreath. The nest is a mere depression in the ground, lined with a few dried grasses or leaves.

\section{KILDEER PLOVER.}

\section{Egialites vociferus (L.) Bp.}

Chars. Plumage not speckled; below, white; head and neck with black bands in the breeding season. Tarsus about half as long again as the middle toe. Rump and upper tail-coverts tawny or orange-brown, most of the tail-feathers white at base and tip, suffused with orange-brown in a part of their length, and with I to 3 black bars; secondaries mostly white, and primaries with a white space; forehead white; a black bar across the crown, and two broad black bands on the neck and breast; bill, black; feet, pale grayish-blue. Length 9.00-10.00; extent, 20.00 ; wing, 6.00 or more; tail, 3.50 , much rounded; tarsus, about 1.50 . 
The Kildeer's presence in New England is under circumstances entirely different from those that attend the appearance of the two species last described. Though it is one of the birds most generally disposed over North America, and though its piercing cry is often heard in our fields and along our estuaries, the bird is less common in New England and eastward than in most other portions of our country. Not at one with the

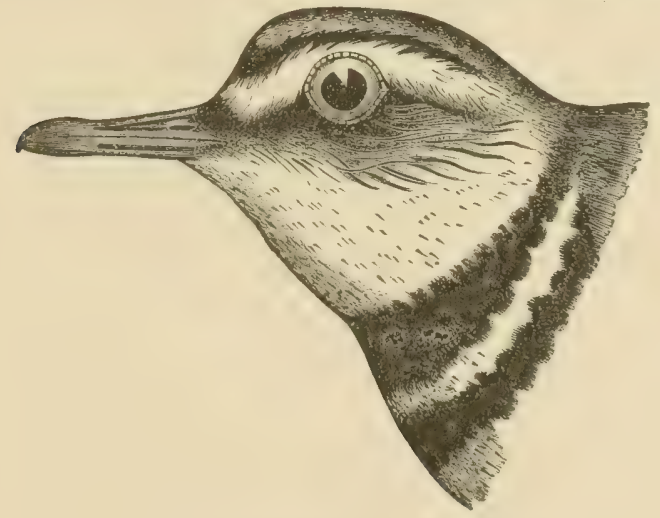

Fig. 3S. - Kildeer Plover. Natural size.

other species of its own genera in having a specially restricted habitat, it also cliffers from the species of Charadrius and Squatarola in breeding indifferently throughout its extensive range - the bird being apparently wise enough to give up that search for the North Pole which is the fashionable infatuation of the present day. Sometimes it reaches New England from its winter quarters by the latter part of February; its numbers increase in March; it nests with us, and seems in no haste to depart in the fall, lingering, like the Kingfisher, till it is fairly frozen out. The nest of this bird and of the 
Spotted Sandpiper are those which, of all the waders, are oftenest found - it is merely a slight depression of ground, either in a bit of shingle by the water's edge, or in some grassy meadow or marshy spot not far from open water. The eggs are usually four in number, very broad at one end and pointed at the other, measuring 1.50 to 1.60 long by about I.10 broad. The ground is a creamy clay-color, sometimes tending to brownish but thickly blotched, spotted and scratched with dark or blackish brown. The markings are usually of small size, tending to speckles and scratches rather than full spots, comparatively few specimens being boldly blotched at the longer end, where the markings tend to aggregation, though they are oftenest numerously distributed over the whole surface. They are usually laid in May; and not improbably in some cases a second set is deposited later in the season.

\section{WILSON'S PLOVER.}

\section{Egialites wilsonius (Ord) Cass.}

Chars. Pale ashy-brown, merging into fulvous on the nape; a black bar on the crown, and a broad black pectoral belt, grayishbrown in the female and young; no bright ring round eye; legs, flesh-colored; bill, black, extremely large and stout, nearly as long as the head. Length, 7.00-8.00; extent, I 5.25 ; wing, $4.50-$ 5.00 ; tail, 2.00, nearly square; bill, 0.80 ; tarsus, I.20.

Unlike any of the foregoing Plovers, Wilson's is a southern species, of restricted range in the United States, and probably confined to the sea coast. So rarely does it proceed northward beyond the coast of 
the Middle States, that its presence in New England has been denied. Dr. Brewer wrote in 1875 : "I am in doubt in regard to this species. It is not of Massachusetts, although my name is usually quoted as authority therefor. Its occurrence on the coast of Connecticut is quite probable, but as I have no data therefor, I take it from among the birds of New England, at least for the present" (Pr. Bost. Soc., xvii, I 875, p. 452). In I878, Mr. Allen includes it only hypothetically among the birds of Massachusetts, stating that there appears to be no recent well authenticated instance of its occurrence north of Long Island (Bull. Essex Inst., x, I878, p. 33). For Connecticut, Mr. Merriam allows the Rev. Mr. Linsley's early record of a capture at Stratford, adding Mr. J. P. Giraud's authority for its occurrence on Long Island (Rev. B. Conn., I877, p. I02).

This was one of the species which caused quite a controversy between Dr. Brewer and Mr. Purdie (Bull. Nutt. Club, i, I876, pp. 72, 9I ; ii, I877, pp. I3, 46). The sum of the evidence at that time appears to have been correctly inclicated by Mr. Purdie (1. c., I877, p. I3); it consisted of the bird's known appearance on Long Island; the Linsley record, which was perhaps properly considered open to question; Mr. Allen's statement (in Am. Nat., iii, I 869) to the following effect: "It hence seems unquestionable that they sometimes occur in southern New England, and it would not be strange if they should occasionally reach the coast of Massachusetts;" together with the general statement of the bird's habitat by Coues, in the Birds of the Northwest : "North to Long Island and Connecticut, probably to Massachusetts, but rare beyond New Jersey."

There is a late Long Island record by Wm. Dutcher, 
of a specimen shot in Shinnecock Bay, May 28, 1879 (Buil. Nutt. Club, iv, I879, p. 242).

Whatever uncertainty may attach to the early New England records, there can be none respecting that recently given by Coues, of a specimen shot by Mr. Arthur S. Fiske, at Gurnett, Mass. (not "Conn." as printed), Aug. 22, I 877 (Bull. Nutt. Club, vii, I882, p. 59).

If our collectors will keep a sharp looknut, no doubt other specimens will be forthcoming in due time, not only from Connecticut, but also from Massachusetts. This Plover is one of the "beach bircls," not unlike the Semipalmated and Piping Ring Plovers in general appearance, but instantly to be distinguished by its larger size and great black bill. It nests on the shingle back of the beach, and its eggs, usually 3 in number, offer the following characters: "Length, 1.22 to $\mathrm{I} .45$; breadth, 1.00 to I.05; ground-color, pale olive-drab, more inclining to green in some cases, to brown in others, but always very pale, thickly marked all over with blackishbrown in irregular, sharply-defined spots, small splashes, and fine dots. In some specimens the markings show a tendency to run into fine lines, and in these are the smallest, darkest and most numerous [most evenly distributed], and most sharply outlined; but ordinarily the distinctive speckled character is maintained. Commonly the markings are rather larger, and consequently more thickly set, on the larger part of the egg, where there is also some tendency to run together, though scarcely to form a ring around the butt; but in none of the specimens examined was the pointed end free from spots. Here and there may usually be observed a few pale, obsolete spots, but they are not conspicuous; in fact, hardly to be detected without close scrutiny." 


\section{SEMIPALMATED RING PLOVER:RING-NECK.}

\section{AEgialites semipalmatus ( $B p$.) Cab.}

Chars. Dark ashy-brown, with an olivaceous shade; very broad coronal and pectoral black bars, in the adult of both sexes, that on the breast grayish-brown in the young, but still evident; edges of eyelids bright orange; bill moderately short and stout; orange or yellow, black-tipped; legs yellowish; toes conspicuously semipalmate. Length, about 7.00 ; extent, I 4.00 ; wịng, 4.50 ; tail about one-half as long as the wings, rounded; bill, 0.50 ; tarsus, I.00.

Two species of "Ring-necks" are abundant on the New England beaches, in flocks usually, mixing indiscriminately with the various kinds of Sandpipers. These two are the Semipalmated and the Piping - both of whose trim and agile forms are mirrored in the glassy surface of the wet sand as they nimbly follow the retreating wave to pick up the tiny creatures that the sea has cast at their feet for food, or still more swiftly speed back from the incoming breaker which would engulf them. It is hard to say which of the two is the commoner during the migration. In the breeding season the Semipalmated will scarcely be seen, for most of the individuals which migrate along the Atlantic coast proceed beyond our limits before stopping to nest - to Labrador, the shores of which are a favorite breeding place, and even still further north. Some, however, are said to linger through the summer with us; Mr. Samuels speaks of a pair nesting on Muskeget Island, off the coast of Massachusetts, and many other pairs are content with the sinuosities of the Maine coast. The arrival of the Ring-necks in spring is somewhat in advance of the 
great body of migrants among the land birds, occurring during the latter part of April, though their numbers are greatly augmented by the middle of May. The return movement of those individuals that do not remain to breed is quite early - some appear in July ; the birds become very numerous in August, and so continue well through September. Thousands are annually destroyed by the boys and pot-hunters, who do not hesitate to decimate their ranks by murderous discharges into the innocent and unsuspecting flocks. The numbers of these and other beach birds have been sensibly diminished in the years intervening since the present writer was guilty of the same atrocities.

For its nesting place, the Semipalmated Plover commonly selects some grassy spot on the marshes back of the beach, oftenest near one of the numberless muddy estuaries that find their way back from the sea line. The nidification is not peculiar - merely a slight depression in the ground, lined with a few blades of grass. The eggs are scarcely to be distinguished from those of the Kildeer, excepting in size - the largest being only about I. 40 by 0.95 , and the dimensions thence running down to 1.20 by 0.90 . The ground color ranges from quite olivaceous drab to pale clay color, or even grayishwhite, some of the lighter-colored examples resembling eggs of the Piping Plover quite closely. Compared with Kildeer's eggs, the markings are usually more definite, larger and bolder, with little of the scratchiness of the latter. A few obscure shell-markings may usually be observed. The full normal number is four, though three, and even only two, may be deposited - the fewer numbers being generally observed in cases of birds which nest in the higher latitudes. 


\section{PIPING PLOVER: PALE RING-NECK.}

\section{Egialites melodus (Wils.) Bp.}

Chars. Coloration above, very pale, ashy-brown; the black bands about the head narrow, that on the neck rarely, if ever, forming a perfect ring. In the young, both of this species and the preceding, the black bands are deficient, being replaced by dark ash. This species is easily distinguished from the last, not only by its coloration, but by its very short, stout, obtuse bill, and lack of any evident webbing between the middle and inner front toes. It is likewise smaller.

As indicated in the preceding notice of the Semipalmated Plover, the Piping is one of New England's summer birds, breeding all along our coast; and it does not appear to proceed much north of Maine for that purpose. It is particularly abundant on the coast of southern New England in May, and during August and September, and much more conspicuous at such times, when flocking on the beaches, than when clispersed in pairs to breed. The breeding habits are closely correspondent with those of its southern relative, Wilson's Plover; that is to say, it lays in the bare shingle of the sea-coast, rather than in muddy and marshy places back of the beach line. The eggs, too, are almost exactly like those of Wilson's Plover, excepting that they are smaller. They may be distinguished at a glance from those of the Ring-neck by their light color and fine, sparse speckling. The ground is clay-color, or palest possible creamy-brown, marked nearly uniformly all over, but sparsely, with small blackish-brown dots and specks, but no spots of any size nor scratchy lines; the largest markings observed scarcely exceed a pin's head. 
The dotting is sometimes extremely fine, mere points, and with it appear to be always mingled a few obscure shell-markings of lilac or lavender. The egg appears to be about of the same size (capacity) as that of the Ringneck, but is rather less elongate and pointed. Several specimens measure: 1.30 by $1.00 ; 1.25$ by $1.00 ; 1.20$ by 0.95 , etc. Four is the usual number, laid late in May or early in June. 


\section{FAM. HAMATOPODID $Æ$ : OYSTER-CATCHER.}

\section{AMERICAN OYSTER-CATCHER.}

\section{HæMATOPUS PALliatus Temm.}

Chars. Feet, 3-toed, very stout and rough, red. Bill, stout, straight, longer than head, much compressed, truncate at ends something like a Woodpecker's, red. Head and neck sooty blackish, changing to blackish-brown on the back and wings. Under parts of the neck, white; a large white space on the wings. A red ring around eyes. Sexes alike. Length about 18.00 ; extent, 34.00 ; wing, 10.00; tail, 4.25 ; bill, 3.00 or 4.00 ; tarsus, 2.50 .

This curious bird, though not particularly southern, and common enough along the coasts of the Middle States, where it breeds, is nevertheless a very rare spe-

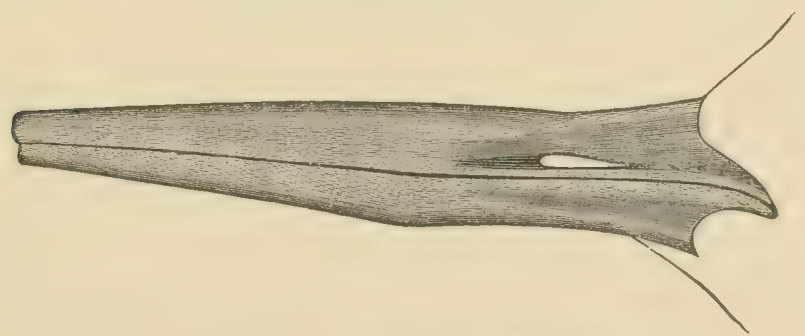

Fig. 39. - Bitz of Oyster-Catcher. Natural size.

cies in New England now, however common it may formerly have been. The Oyster-catcher is confined strictly to the sea-coast, and is one of the wildest and wariest of the beach birds - facts which may account in part for its scarcity along shores where men are plentiful. Among the old records of its appearance are those 
given by Brewer in Peabody's Report of the Ornithology of Massachusetts, I839, p. 358, by Emmons in Hitchcock's Report, 1835, p. 5-both perhaps a little dubious, and by Linsley in the Amer. Jour. Sci., xliv, I 843 , p. 265, who says that the Oystercatcher was then rare in Connecticut, though it had not been uncommon in autumn a few years previously. Coming to later notices, we find Coues remarking that the bird is of very unusual occurrence along our coast (Pr. Essex Inst., v, I868, p. 292). Mr. Maynard notes it as accidental, but one or two instances of its capture being on record (Nat. Guide, I870, p. I 39); while Mr. Allen calls it "accidental in summer" in Massachusetts (Bull. Essex Inst., x, I 878, p. 23). Dr. Brewer's general list of New England birds includes the species with the asterisk, and notes Massachusetts and Maine as localities - the latter doubtless on the excellent authority of Mr. Boardman of Calais (Pr. Bost. Soc., xvii, I875, p. 445).

\section{TURNSTONE OR CALICO-BIRD.}

\section{Strepsilas interpres (L.) $I l l$.}

Chars. Feet, four-toed, red. Bill, dark-colored, hard, acute, in this respect differing from that of most wading birds - the modification of the organ, like that which the singular instrument of the Oyster-catcher has undergone, being in adaptation to the particular habits of the bird. The Oyster-catcher uses its singular tool as a burglar does a "jimmy," to pry open the shells of bivalve molluscs. As indicated by the name "Turnstone," the beak of the latter bird is used to dislodge pebbles along the seashore, to get at the odd little marine creatures that lurk beneath them. In other respects, the general habits of the Turnstone 
agree with those of Sandpipers, and its haunts are similar, though it naturally prefers rocky coves and shingly places to the open sandy beaches. The sexes are alike, but the summer and winter plumages differ greatly. In the former season the bird is singularly patched and pied on the upper parts with black, white, gray and chestnut, giving the suggestion of printed calico; the under parts, and a large space on the wings, are pure white, excepting the black on the breast. In winter the reddish coloration is wanting. Length about 8.00 ; extent, 17.00 ; wing, 5.65 ; tail, 2.40 ; bill, 0.90 ; tarsus, 1.10 .

A common spring and autumn migrant through New England, almost exclusively along the sea-coast. It is not found in flocks, like the Sandpipers generally, but alone, or only two or three together, sometimes associating with the Sandpipers, but oftener satisfied with its own company. It appears among us in April, and sometimes remains through the greater part of May, after which it is off to the hyperborean regions where it breeds. It returns in August, more numerous-

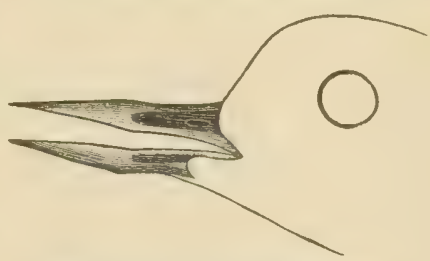

Fig. 40. - Bit.l OF TURNSTONE. Natural size.

ly than before, and lingers through the greater part of the autumin. It is one of the most widely diffused of birds, being found on the sea-coasts of nearly all countries, and on many of the larger inland waters of North America, as of other continents. Its peculiarities almost entitle it to be considered as the type of a family Strepsilaide, in which might be also classified its near relative, the curious Surf-bird of the Pacific, Aphriza virgata. 


\section{FAMILY RECURVIROSTRIDA: AVOCETS: STILTS.}

\section{AMERICAN AVOCET.}

\section{Recurvirostra americana $G m$.}

Chars. Legs, blue, very long; feet, 4-toed ; toes, webbed. Bill, black, longer than head, very slender and excessively acute, turned up at the end. Iris, red. Head and neck, cinnamonbrown in summer, ashy in winter; back, wing-coverts and primaries, black ; general plumage and under parts, white. Length, 17.00 ; extent, 30.00 ; wing, 9.00 ; tail, 3.50 ; bill, 3.00-4.00; tarsus, 3.50. Female usually smaller than the male.

This is a bird of extraordinary configuration and bizarre coloration. Having long legs, like any wader - in fact, the length of leg exaggerating a usual proportion - the feet are nevertheless webbed like those of a swimming bird, and the body is flattened underneath, with thick, duck-like plumage to resist the water. The bill is unique, resembling a shoemaker's awl in slenderness, sharpness and curvature - and the curve is upward. The black and white pattern of coloration, with the cinnamon head and neck and blue legs, adds to the singularity of its appearance. The color of the legs suggests the ludicrous name of "blue-stocking," sometimes applied ; but the bird differs from those creatures of our own species which have been so nicknamed, in being harmless, interesting and instructive.

The Avocet is irregularly distributed over nearly all of temperate North America, from one ocean to the other, and from rather high latitudes in British America to Mexico and the Gulf. Still, there are large tracts of 
country seldom visited, and New England is one of these. Here the bird is little more than a straggler, though not rare further South on the Atlantic coast. It thus becomes necessary to examine the records for cases of its occurrence among us.

The record left by the Rev. Mr. Linsley is discredited by Mr. Merriam (Rev. B. Conn., I877, p. I46) as resting upon insufficient evidence. But Mr. Merriam is able to furnish an authentic instance of the presence of

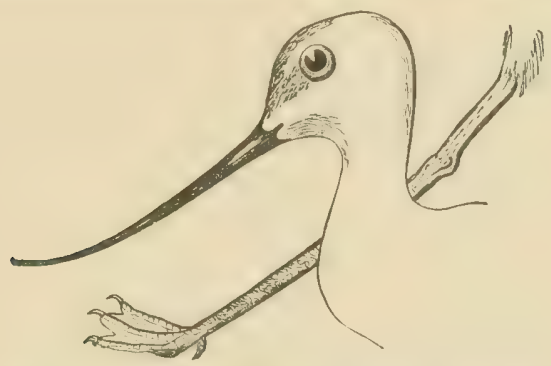

F1g. 41. - Head and Leg of Avocet. Reduced.

the bird in Connecticut, one of his correspondents, Mr. J. G. Ely, writing to him, that a specimen was found in I87I, between Saybrook and East Lyme, in an old seine strung out on the beach to dry (Rev. B. Conn., I 877, p. 103). Dr. Brewer states this to be "the only instance of its capture within our limits that is on record, all the others having been extra-limital or without particulars" (Pr. Bost. Soc., xix, 1878, p. 307). Mr. G. A. Boardman had indeed noted some years before (Pr. Bost. Soc., $\mathrm{ix}, \mathrm{I} 862$, p. I28), the capture of a specimen in Maine, but this turned out to have been taken in New Brunswick. In 1875, therefore, Dr. Brewer removed the species from the New England List, with the following comments: "This has been placed among the Birds of 
New England by Prof. Verrill and Dr. Coues, on the strength of a single specimen said to have been taken by Mr. G. A. Boardman, near Calais. As the specimen was not taken near Calais, but at Point Lepreaux, New Brunswick, we are without any evidence that this bird belongs to our fauna, and therefore I take it out" (Pr. Bost. Soc., xvii, 1875 , p. 452). In preparing the Massachusetts list in $1878, \mathrm{Mr}$. Allen could find no authority for including the Avocet among the birds of that State, and accordingly only gave it a hypothetical place, on the strength of the 1862 New Brunswick, and the I87 I Connecticut cases above mentioned (Bull. Essex Inst., $x, 1875$, p. 34). These seem to have remained the only authenticated records until very recently. Mr. N. C. Brown has given the interesting note of the capture of a specimen at Cape Elizabeth, Maine, Nov. 5, I 878 (Bull. Nutt. Club, iv, I879, p. I08). Mr. Purdie has noted another taken in Natick, Middlesex Co., Mass., making the third authentic New England one, and the first for Massachusetts (Bull. Nutt. Club, vi, I\$8 I, p. 123). Mr. G. A. Boardman and Mr. Montague Chamberlain have each lately noticed the casual occurrence of Avocets in New Brunswick (Bull. Nutt. Club, v, I880, p. 24I, and vii, 1882, p. 105).

\section{BLACK-NECKED STILT. \\ Himantopus mexicanus (Miill.) Ord.}

Chars. Legs, exceedingly long, slender, red; feet, semipalmate; no hind toe. Bill, black, very slender and acute, longer than head. Iris, red. Color, white, with lustrous black wings and back, and black stripe up back of neck. Length about 15.00 ; extent, 27.00 ; wing, 8.75 ; tail, 3.00 ; bill, 2.50 ; tarsus, 4.00 . 
The case of this bird, probably the longest-legged feathered biped in proportion to the size of its body, is quite similar to that of the Avocet, so far as its presence in New England is concerned. It is simply a straggler, though it is known to have occurred oftener than the Avocet has been ascertained to have donefor, as we have seen, there are only three unexceptionable records in the case of the latter species. Nearly every writer upon our New England birds refers to the Stilt, but in terms that leave their remarks open to objection, and the earlier authorities on the subject may be passed over. I have learned of no Connecticut occurrence. For Massachusetts, Mr. Maynard has usually of late been quoted as authority. This writer says that

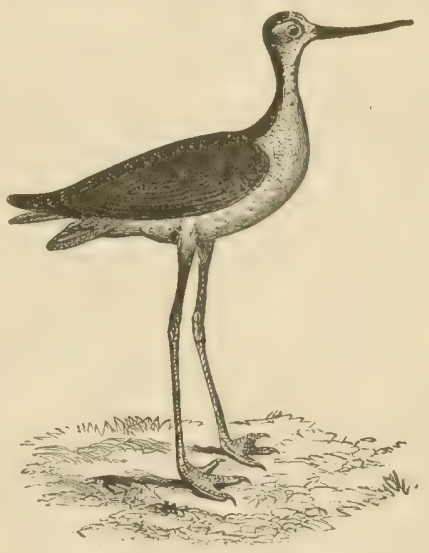

Fig. 42. - BLACK-NECKED StILT. he was " assured by gunners and others," that it was occa. sionally seen along the sandy beaches (Nat. Guide, I870, p. I43). This authority is cited by Allen (Am. Nat., iii, I870, p. 638 ; and Bull. Essex Inst., x, I878, p. 23), who also brings up the testimony of Mr. Boardman, to the effect that the latter saw, some years previously, in the Boston market, two specimens which he was assured had been taken in Massachusetts. The only positive and unequivocal case that has come to my knowledge is that given by Mr. Boardman, of a specimen taken at Calais, Maine, in I 862 (Pr. Bost. Soc, ix, I862, p. I 28). For New Brunswick, see Chamberlain, Bull. Nutt. Club, vii, I882, p. 105 . 


\section{FAM. PHALAROPODIDA: PHALAROPES OR COOT-FOOTED SANDPIPERS.}

\section{WILSON'S PHALAROPE. \\ Steganopus Wilsoni (Sab.) Coues.}

Chars. Bill long, equalling the tarsus, exceeding the head, extremely slender, terete and acute. Culmen and gonys broad and depressed. Lateral grooves long and narrow, reaching nearly to tip of bill. Interramal space narrow and very short, extending only half way to the end of the bill. Nostrils at the extreme base of the bill. Wings of moderate length. Tail short; deeply doubly-emarginate; legs greatly elongated; tibiæ bare for a considerable distance; tarsus exceeding the middle toe. Toes long and slender, broadly margined with an even, unscolloped membrane, united but for a brief space basally. Claws moderately long, arched and acute. Adult in breeding dress: Bill, legs and feet, black; crown of head, pale ash, passing into white along a narrow strip on the nape. A narrow, distinct, pure white line over the eye. Sides of neck intense purplishchestnut, or dark wine-red; anteriorly deepening upon the auriculars into velvety black; posteriorly continued, somewhat duller in tint, as a stripe along each side of the back to the tips of the scapulars. Other upper parts pearly-ash, blanching on the rump and upper tail-coverts. Wings pale dull grayish-brown; the coverts slightly white-tipped, the primaries dusky-brown, their shafts brownish-white, except at tip. Tail marbled with pearlygray and white. All the under parts pure white, but the forepart and sides of the breast washed with pale chestnut-brown, as if with a weak solution of the rich color on the neck, and a faint tinge of the same along the sides of the body to the flanks. The female is larger and handsomer than the male. Length, 9.50; extent, 16.00 ; wing, 5.00 ; tail, 2.00 ; bill, 1.25 ; tarsus, 1.25. Specimens just fledged are in a plumage not generally known : 
Bill, blackish, about r.1o long; legs, dull yellow (tarsus, I.20; middle toe and claw, 1.05). Upper parts, including crown and upper surface of wings, brownish-black, each feather edged with rusty-brown, very conspicuous on the long inner secondaries, and giving a general aspect like that of a Sandpiper of the genus Actodromas. Upper tail-coverts pure white. Tail clear ash, edged and much marbled with white, the ash darker at its line of demarcation from the white. Line over eye, and whole under parts, white, the breast with a faint rusty tinge, and the sides slightly marbled with gray. Quills dusky, the secondaries whiteedged, and the shafts of the primaries whitish. This stage is of extremely brief duration, beginning to give way, almost as 'soon as the bird is full grown, to the clear uniform ashy of the upper parts of the fall and winter condition. The change in some specimens shot early in August is already very evident, clear ashy feathers being mixed, on the crown and all the upper parts, with such as just described. Size of the smallest specimen only 8.25 in length by 14.50 in extent; wing, 4.60 .

Several wading birds, properly so classed, furnish exceptions to the rule that these birds have but slight powers of swimming, only exercised in an emergency. The Avocet is a fair swimmer, the toes being nearly fullwebbed; still better swimmers are the Coots and Phalaropes, birds not very closely allied, yet alike fitted for highly aquatic life and habitual swimming by the presence of broad lobes on the toes. Phalaropes are swimming Sandpipers - with the modification of the feet just mentioned, a thin shank to cut the water, a depressed boatshaped body to rest upon it, and thickened, duck-like under plumage to prevent wetting of the body. Not one of the waders surpasses the Phalaropes in ease and variety of movement, grace and elegance of form, or beauty of color when in perfect plumage; and Wilson's Phalarope is the most beautiful of them all. Their domestic relations, however, are simply scandalous. The 
fair sex conducts the courtship, and several of them may be seen in spring pursuing some modest male, who undertakes the rôle of St. Anthony without success, and when captured, submits with what grace he may to incubating such eggs as his flourishing partner assures him are his own.

The chorus of New England writers swells into one grand symphony in treating of this bird's presence in

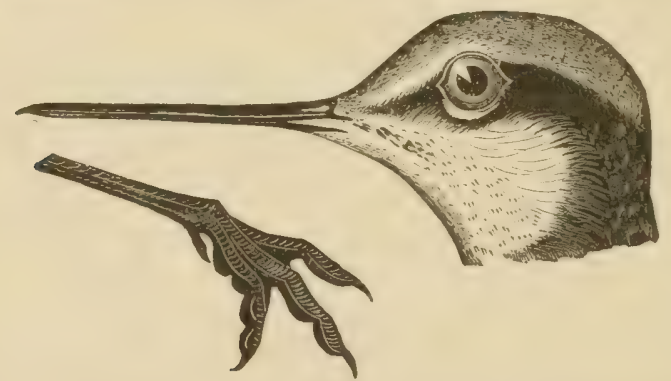

Fis. 43. - Head of Wilson's Phalarope. Fig. 44. - Foot of Northern Phalarope. Natural size.

their country, the theme being that Wilson's Phalarope is a rare straggler. So true is this statement that I have been unable to find more than a single authentic case recorded of late years. Much that has been intimated on the subject seems to flow from some statement made by Audubon. I have not had time to look up what he says; but the reader who can tear himself away from these fascinating pages long enough to do so, will be able to inform himself on the subject (see Orn. Biog., iii, I 835 , p. 400 ; 8 vo. ed., v, I 842, p. 299). As so frequently proves to be the case, the Rev. J. H. Linsley is good authority, and the only one we have so far, for the recurrence of this Phalarope in Connecticut. He speaks of a specimen killed in Bridgeport, and sent to him by 
a friend (Am. Jour. Sci., xliv, I843, p. 268). Merriam copies this statement as his only Connecticut authority (Rev. B. Conn., 1877, p. 103). All the following records appear to flow from Audubon, and to be without later confirmation :- Putnam, Pr. Essex Inst., i, I856, p. 217 ; Allen, Pr. Essex Inst., iv, I864, p. 86 ; Coues, Pr. Essex Inst., v, I868, p. 292 ; Brewer, Pr. Bost. Soc., xvii, I 875. p. 445 ; Allen, Bull. Essex Inst., x, I878, p. 23. We have, however, an authentic Rhode Island instance (Newport, Aug. 2, I880; Jencks, Bull. Nutt. Club, v, I880, p. 237).

\section{NORTHERN PHALAROPE. \\ Lobipes hyperboreus (L.) Cuv.}

Chars. Bill generally as in Steganopus, but shorter, basally stouter, and tapering to a very acute, compressed tip ; ridge of culmen and gonys less depressed; interramal space longer and broader. Wings long. Tail short, greatly rounded. Legs and feet, short; tibia denuded for but a brief space; tarsus not longer than the middle toe. Toes very broadly margined with a membrane which is scolloped or indented at each phalangeal joint, and united basally as far as the second joint between the outer and middle toe, and as far as the first joint between the inner and middle toe. The feet are thus semipalmated. Claws very small and short. Coloration something like that of Wilson's Phalarope; but the much smaller size of the species, together with the generic characters here given, will suffice for identification. Length, 7.00; extent, 13.50; wing, 4.25; tail, 2.00 ; bill, I.00; tarsus, 1.00 .

Though we are already among the "water birds," we have not yet seen any one to be fairly called an off-thecoast or sea-bird proper. This Phalarope, however, is such a creature, and a very curious compound it is of a wader and a swimmer. Take one of our common little Sandpipers, fit it for sea by making oars of its feet, and 
launch it upon the great deep - you have the Northern Phalarope. You may see a flotilla of these little animated cockle-hoats riding lightly on the waves anywhere off the coast of New England. Let a storm arise too violent for such frail creatures to outride, and they will run into harbor anywhere, or even be blown far inland. Such facts as these give the clue to the occasional and irregular occurrences of the Phalarope in New England. They are not rare - hundreds and thousands of them disport off the coast during a great part of the year. Thus Mr. Harold Herrick remarks upon their abundance about Grand Menan : "Thousands may be seen all summer on the 'Ripplings' about eight miles from Menan, where they congregate to feed on the shrimps and animalculie that are drifting in the eddies made by the advancing and receding tide. They never come on shore unless driven by storms, and are so tame, especially in foggy weather, that I have almost run them down with a small boat."

The statement of the appearance of the birds "all summer" leads to the inference that they breed with us, but I do not know that the fact has been established. They are chiefly known as spring and summer vagrants along the coast, as not common, and as irregular at that. Their general range is very extensive, embracing the coast lines and large inland waters of most of the northern hemisphere. They are known to breed in very high latitudes, and to migrate to the tropics in winter. Thus they occur in Spitzbergen in summer, and on the shores of the Polar sea. That they are not strictly maritime is shown by the fact of their presence in our great lakes and rivers, as in Ohio, Illinois, Wyoming, etc.

Large series of eggs of this Phalarope show such a 
range of variation in color that it is difficult to describe them intelligibly. The ground varies from dark greenish-olive, or brownish-olive, through various lighter drab-tints, nearly to a buffy-brown, and in some instances to a light grayish-drab. The markings are usually very bold and heavy, consisting of large spots and the still larger splashes produced by their confluence, mingled with dots and scratches in interminable confusion. The markings are, in general, pretty evenly distributed, sometimes aggregated about the butt, and in rarer instances forming a complete, definite circle. In a few instances all the markings are mere dots. In general, the heaviness and size of the markings bear some proportion to the intensity of the ground-color. The color of the markings is dark bistre, chocolate, and sometimes still lighter browns. The longest and narrowest egg measures I.3O inches by only 0.75 ; a short and thick one only I. Io by 0.82 ; average about I.20 by 0.80 . The eggs are three or four, oftenest four, and are laid in June - more frequently in the latter half of the month - in a depression of the ground, variously lined with withered vegetation.

\section{RED PHALAROPE.}

\section{Phalaropus fulicarius ( $L$. $) B p$.}

Chars. Bill scarcely longer than the head or tarsus; very stout for this family ; much depressed; so broad as to be almost spatulate, the tip only moderately acute. Upper mandible with the ridge broad and flattened, its apex arched and decurved, its lateral grooves wide and shallow. Interramal space broad and very long, extending nearly to the end of the bill. Nostrils sub- 
basal, at some distance from the root of the bill. Wings long and pointed. Tail long, rounded, the central rectrices projecting, rather acuminate. The legs and feet are much as in Lobipcs, but the semipalmation is of less extent. The species, in any plumage, is readily distinguished from the Northern Phalarope by these generic characteristics. The plumage is very variable according to season. In full breeding dress, the under parts are dull mahogany-brown; the upper parts slate-gray, varied with blackish and yellowish; the bill yellowish, with dark tip. In size between Wilson's and the Northern Phalarope.

The remarks offered upon the Northern Phalarope apply without qualification to the present species, the manner of whose appearance in New England is substantially the same. It occurs along the coast chiefly as a migrant, and is not common or regular in its appearance. There is no occasion to cite particular records of its capture, as these simply confirm what has been advanced in general terms. Mr. Boardman speaks of its being, like the last species, a summer resident along the coast of Maine, and it may not improbably be found breeding there, like its nearest ally, with which it so commonly found associated. The mode of nesting is the same, and the eggs are not to be distinguished with any certainty, though averaging larger. Specimens before me from Arctic regions measure I.30 by 0.90 ; I. I 5 by $0.90 ; 1.25$ by 0.85 . 


\title{
FAMILY SCOLOPACID E: SNIPE, ETC.
}

\section{THE WOODCOCK.}

\author{
Philohela minor $(G m) G$.$r .$
}

Chars. Under parts russet, varying from pale reddish-buff to ruddy brownish; generally palest on the throat. Upper parts intimately varied with russet, black, brown and silvery-gray; an irregular dark line from bill to eye. Head peculiarly shaped, with large eyes in the back upper corner. Bill perfectly straight, much longer than head, high ridged at base, amply furrowed, very sensitive at the end, the knobbed tip of the upper mandible overhanging the end of the lower mandible; gape of the mouth much contracted. Legs short for a wader, feathered to the heei; toes, long and slender; tail short; wings rounded, with several outer primaries narrowed and falcate, bistoury-like. Body plump; neck short. Female larger and heavier than the male. Length, about I1.00; extent, 18.00; wing, 5.00 ; tail, 2.50 ; bill, 2.50-3.00; tarsus, I.I 5 .

The Woodcock is found in nearly all parts of the United States east of the Mississippi, and in adjoining British Provinces. Occurring thus both north and south of New England, it is in that section of country more numerous during the migrations than at other seasons; more numerous in summer than in winter; yet actually a permanent resident. There is no month in the year in which Woodcock may not be found. These are the final facts in the case; more superficially and practically, the bird is a summer resident, arriving as soon the snow leaves, and departing with the freezing of the watery soil in which its 
food is sought. March and April, and October, are the moving months. From early in April to some

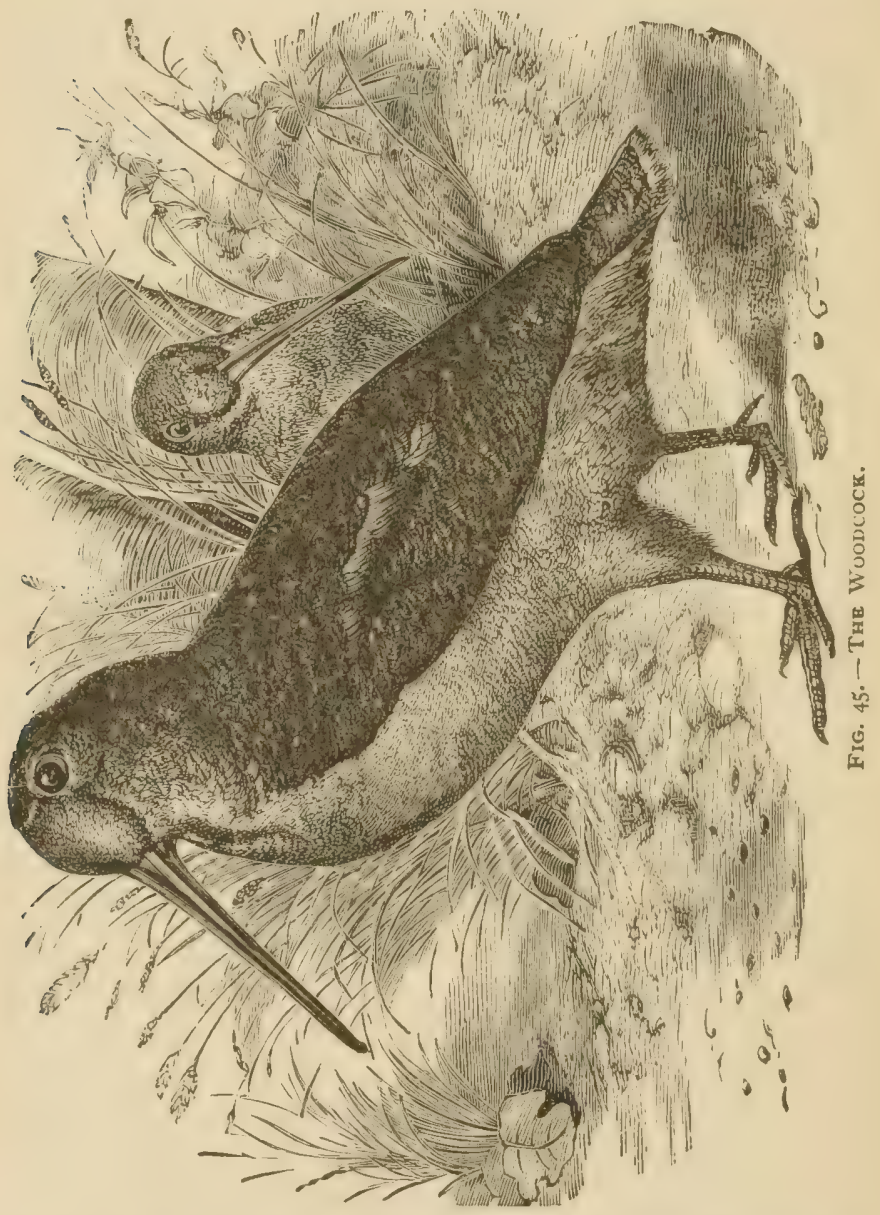

time in May are the laying and incubating periocis; domestic concerns occupy the birds in the rest of May 
and in June, after which, with the celebration of the American political idea, - now old enough to be less barbaric in its methods of self-glorification, - the Woodcock season begins; that is to say, a considerable proportion of the young birds are grown strong enough to fly in order to be shot. It is a twin relic of barbarism that allows them to be killed at this tender age; the close time should not cease before September, in which month as well as the succeeding one, the best sport may be had. But whether or not July shooting be permissible, Woodcock should be let alone in August, when they are moulting, and poorly able to take care of themselves. The regular course of events may be interfered with by irregularities in the season, or the otherwise accidental destruction of eggs, causing very late broods to appear.

Nesting is early - by the middle of April eggs are to be found in their slight nests - mere depressions in some dry spot in swampy land, generally the cover of alders and birches, sometimes more open places. The normal number of eggs is four, averaging in size about I. $50 \times 1.20$; they are, however, as variable in dimensions as in coloration, which latter is some shade of buff, thickly spotted and blotched with browns, neutral and lilac tints. In shape, they are less prominently pyriform than those of most waders. It is a fact that when danger threatens, the parent will transport her callow young to a place of greater security, carrying them either in her claws, like a hawk, or close-pressed to her lower bosom between the legs. The Woodcock is largely nocturnal, feeding most by night. During the courtship, it has a variety of extravagant actions both in the air and on the ground, accompanying the display 
with curious sounds, sometimes musically modulated. When sitting closely little or no effluvium is disengaged, so that the best dog may be at fault, though passing close by the nest. The general habits of the bird, from the sportsman's standpoint, are too well known to need description. I am inclined to think the swiftness of the bird on wing is exaggerated, the difficulty in shooting it down arising rather from the irregularity of its course, and the thickness of the cover in which it is usually flushed.

Note. - The European Woodcock, Scolopax rusticula, is a straggler to this country, and has been taken at points which render it probable that it passed New England to reach them (Newfoundland, Long Island, New Jersey, Virginia). It has consequently been included hypothetically in the New England List. Though the inference is permissible, the fact remains to be demonstrated. It may be recognized, among other characters, by its greatly superior size and lack of the attenuated outer primaries.

\section{THE AMERICAN SNIPE; WILSON'S SNIPE.}

\section{Gallinago wilsoni (Temm.) Bp.}

Chars. Upper parts varied with black, brown, and a buff or reddish shade, the latter forming especially two lengthwise stripes on each side, along the inner border of the wing. Under parts white; throat and breast spotted and streaked with brownish, the lining of the wings and axillary feathers and sides of the body barred regularly with black. Tail barred with black, white and chestnut; some of the lateral feathers narrowed. Crown dark with a median light stripe. Length, about 10.00 ; extent, 16.25 ; wing, 5.00 ; tail, 2.00 ; bill, 2.50 , but variable ; tarsus, 1.40 .

The name of "English" Snipe, of common but erroneous application to this bird, is a misnomer, the 
bird being technically different from that of England, as any one may perceive on comparing the two, though

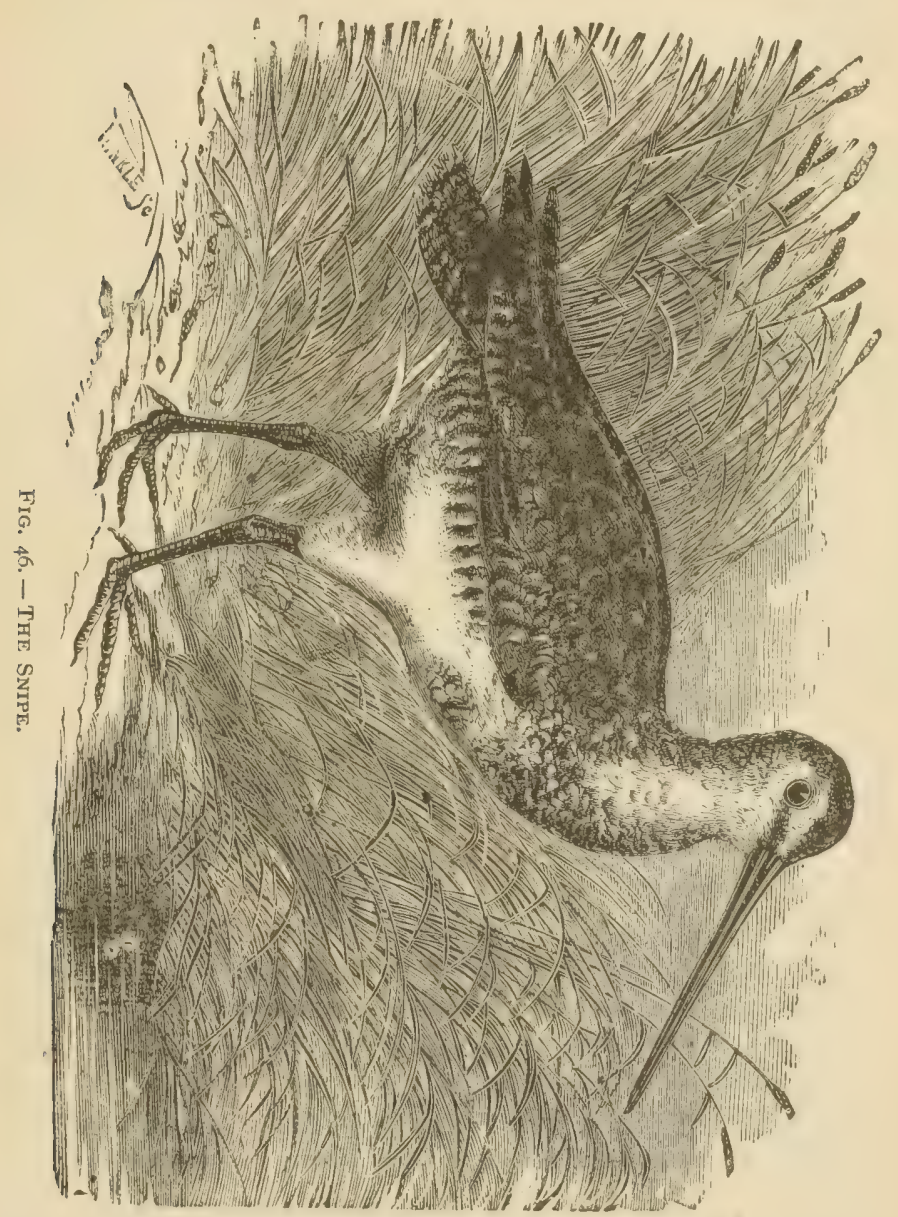

the general resemblance is quite close. It is another of the deplorable instances in which paucity of language 
has caused American birds to be called by the name of their nearest European relative, real or supposed - a circumstance tending to promulgate error and confusion. We should do our best to suppress such wrong names in every instance, even without such an example as the well-nigh hopeless muddle about our Bob-white to warn us. "Jack Snipe" is another soubriquet of our Gallinago, of no obvious application indeed, but not particularly bad, though also employed to designate the Pectoral Sandpiper, Actodromas maculata.

Throughout the greater part of the United States the Snipe is found only during the migrations, and in winter. It breeds, however, in Northern New England, and it may do so along other portions of our northern border. It is almost exclusively a migrant through the United States, though some probably winter in the southern portions. Its migrations are pushed, at that season, even to South America, and it also occurs in Mexico, Central America, and the West Indies, according to numerous extra-limital quotations. The eggs are moderately pyriform, and measure about 1.60 by I.1 2 ; some, however, being so small as 1.50 by 1.95 . The ground color is grayish-olive, with more or less brownish shade in different specimens. The markings are numerous, generally heavy, and often massed, though, as a rule, distinct; they may appear all over the surface, but are always thickest and largest on the major half of the egg. The color is umber-brown, of varying shade, according to the depth or quantity of pigment. With these surface markings are associated some paler or obscure shell spots, not ordinarily so noticeable, however, as in some other species. And over all we find, in occasional specimens, curious sharp, 
straggling lines of what appears to be pure black. The other markings have the ordinary splashed or blotched character. The nest-complement is three or four. A set of eggs in the Smithsonian is labelled Oneida County, New York. The nest is a mere depression in the grass or moss of a boggy meadow; the down of the newly-hatched young is mottled with white, ashy, ochrey, and dark brown.

It is, however, in the character of spring and autumn migrant that the Snipe chiefly figures in New England. Occasionally those that have bred in the high north appear in August; but the migration is not in force until the second week in September, from which period until late in October good shooting may be had. Thespring movement is mainly in April.

I like very well the way in which the collaborator of Minot's Birds of New England has exploded one popular fallacy respecting the Snipe: "In all the accounts of these birds which are accessible to him, the author finds the ancient, time-honored tradition, that the Snipe always begin their flights by rapid zigzags, so that it behooves the shooter either to fire at the instant when the birds attain the height of their first spring or to wait till they have completed their zigzags and begin their steady flight. The beginner, deeply impressed with these statements, his mind filled with the idea that the flight of the Snipe is much like that of a tortuous lightning flash through a cloud, sets out, and, adopting one or the other of these absurd rules, is sure to miss. Inasmuch as the Snipe, five times out of six, in most weather, does not spring at all, to fire at the height of the first spring means to the beginner to fire as soon as he can, that is, as much as possible before he gets his 
aim. On the other hand, to wait till the bird is done with zigzagging necessitates waiting till he has begun zigzagging, and, as he generally does not zigzag at all, this involves waiting some time. From the expression, 'zigzag flight,' would not the natural impression be that the bird kept darting rapidly, with short, quick short turns from side to side? That such is the Snipe's usual fight is certainly not true, though it is undoubtedly often rapid and sometimes eccentric. The author's experience is for these days of rapid travel limited, but after shooting Snipe at different seasons in the British Provinces, in Maine, Massachusetts, Rhode Island, Maryland, Delaware, Virginia, and North Carolina, he ventures to assert that they almost never 'zigzag' in their flight."

\section{RED-BREASTED SNIPE; GRAY SNIPE; BROWN BACK; DOWITCHER.}

\section{Macrorhamphus Griseus ( $G m$.) Lcach.}

Chars. This Snipe as about as large as Wilson's, and the bill is exactly as in that species. It is distinguished by the greater length of the legs, the whole naked portion being about 3.50 inches long, of which the bare part of the tibia is 0.75 of an inch; by a web between the outer and middle toes; by 12 instead of 16 tail feathers, and many points of coloration. Tail and its coverts, with lining of wings and axillars, beautifully barred with black and white or tawny; shaft of first primary white. In breeding plumage, brownish-black above, variegated with bay ; reddish-brown below, variegated with dusky; a tawny superciliary and dusky loral stripe. At other seasons, dark gray above, the feathers with dusky centres and pale gray or whitish edges; lower back pure white ; superciliary line and spot on under eyelid white; below, white, the jugulum, fore-breast, 
and sides heavily shaded with gray, leaving chin whitish; the flanks and crissum with wavy, dusky spots or bars. Length, I0.25 to 10.75 ; extent, 18.00 ; wing, 5.25-5.90, average about 5.60 ; tail, 2.50; tarsus, 1.20-1.55, average 1.35 ; bill, 2.00-2.50, very variable. (The alleged differences of the supposed variety $M$. scolopaceus are given beyond.)

A common spring and autumn migrant. It is also considered by both Dr. Brewer and Mr. Boardman to be a summer resident in northern New England, but we have no definite advices of its breeding in our limits. It certainly nests very far northward, even to the Arctic Coasts of North America, though many individuals re-appear among us in August. The birds become abundant during the following month, and afford excellent sport to the gunners. They frequent mud-bars, flat and marshy meadows, in flocks often of considerable size, and are in good condition for the table.

Of several sets of eggs I have examined, laid either by this species or by var. scolopaceus, high in boreal regions of the United States, one set contains four eggs, another three, another only two; but we must presume that four is the regular nest-complement. The eggs are not peculiar among their

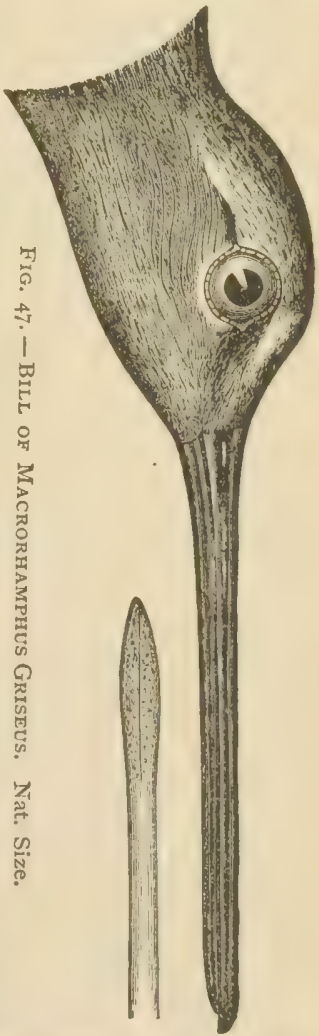
allies in any respect, and probably no description would 
suffice for their positive identification. The following measurements indicate the size and shape: 1.75 by I.I 5 (unusually long, narrow, and pointed) ; 1.70 by I.1 5 ; 1.62 by I.I 2 (about an average); I.68 by I. IO; I. 55 by I. IO (very short). The ground-color is the same as in Gallina$g o$, with all its variation, while the general character of the markings is identical, even to the occasional occurrence of sharp, black tracery over the ordinary spots and blotches. One of the eggrs has the markings rather chocolate than unber-brown, and much smaller and more diffuse than they are in any of the examples of Gallinago which happen to be before me. The Redbreasted Snipe is a gentle and unsuspicious creature by nature, most sociably disposed to its own kind, as well as toward its relatives among the Ducks and waders. In the western regions, where they are not often molested, no birds are more confiding, though none more timid. They gather in such close flocks, moreover, that the most cruel slaughter may be effected with ease by one intent only on filling his bag. As we approach a pool we see numbers of the gentle birds wandering along the margin, or wading up to the belly in the shallow parts, probing here and there as they advance, sticking the bill perpendicularly into the mud to its full length with a quick, dexterous movement, and sometimes even submerging the whole head for a sccond or two. All the while they chat with each other in a low, pleasing tone, entirely oblivious of our dangerous proximity. With the explosion that too often happens, the next moment some stretch dead or dying along the strand, others limp or flutter with broken legs or wings, while the survivors, with a startled wect, take wing. Not, however, to fly to a place of safety; in a compact 
body they skim away, then circle back, approaching again the fatal spot with a low, wayward, gliding motion, and often re-alight in the midst of their dead or disabled companions. No birds fly more compactly, or group together more closely in alighting; it seems as if the timid creatures, aware of their defenceless condition, sought safety, or at least reassurance, in each other's company. Thus it happens that a whole flock may be secured by successive discharges, if the gunner will seize the time when they stand motionless, in mute alarm, closely huddled together. In a little while, however, if no new appearance disturbs them, they cast off fear and move about separately, resuming their busy probing for the various water-bugs, leeches, worms, and soft molluscs, which form their food, as well as the seeds of various aquatic plants. When in good order, they are excellent eating.

Being partly web-footed, this Snipe swims tolerably well for a little distance in case of emergency, as when it may get for a moment beyond its depth in wading about, or when it may fall, broken-winged, on the water. On such an occasion as this last, I have seen one swim bravely for twenty or thirty yards, with a curious bobbing motion of the head and corresponding jerking of the tail, to a hiding-place in the rank grass across the pool. When thus hidden they keep perfectly still, and may be picked up without resistance, except a weak flutter, and perhaps a low, pleading cry for pity on their pain and helplessness. When feeding at their ease, in consciousness of peace and security, few birds are of more pleasing appearance. Their movements are graceful and their attitudes often beautifully statuesque. 


\section{GREATER LONG-BEAK.}

\section{Macrorhamphus griseus scolopaceus (Say) Coues.}

Chars. Very similar to the last, and distinguishable with difficulty, if at all. Averaging larger: wing, 5.40-6.00, average, 5.75 ; bill, $2.10-3.00$, average, 2.70 ; tarsus, $1.35-1.75$, average, 1.60 ; middle toe, $0.95-1.15$, average, 1.00. In summer plumage, abdomen uniform reddish, without markings (in grisens whitish); breast scantily speckled and sides barred with dusky (in griseus, breast and sides speckled with dusky). Young and winter specimens not distinguishable with any certainty from those of griscus, as the dimensions of the two intergrade.

The balance of opinion respecting this doubtful bird seems to have settled in favor of at least its varietal distinction from $M$. griseus. According to the latest authority on the subject, Mr. Ridgway, specimens never occur in western North America which have in summer the abdomen either whitish or speckled, or the sides speckled; these being characters peculiar to birds of the Atlantic coast (true griseus), where these abound in the migrations in the proportion of about a thousand to one of scolopaceus. The coloration as above given is said to be more constant than the dimensions, though scolopaceus averages larger than griscus. Young birds and those in winter plumage cannot be distinguished, excepting those specimens of scolopacens which surpass the maximum dimensions of griscus. (Bull. Nutt. Club, v, 1880, p. 1 58.)

Mr. Newbold T. Lawrence has paid particular attention to this subject, and we extract in substance his article in Bull. Nutt. Club, v, I880, p. I54. Mr. Lawrence says that the bill of scolopaceus varies from 2.50 
to 3.25 in length, while that of griseus seldom if ever reaches 2.50 . "The $M$. scolopaccus not only exceeds the other in length of bill, etc., but the whole general appearance is very noticeably different, and it can be easily distinguished from $M$. griseus some distance off. Mr. George N. Lawrence says: 'In all three of my specimens which are in full summer plumage, the breast and entire abdomen is of a uniform rather pale rufous, without spots or bars, but the sides of the breast are transversely barred with black. In an example from Texas, the breast is barred in the same manner as the ones from Cuba.' In all of the seventeen specimens of M. scolopaceus I have examined," continues Mr. N. T. Lawrence, "the character of the plumage is strongly marked, with still another feature, and that is in having the feathers of the breast and abdomen edged with a lighter rufous or white, this being particularly strongly marked in a specimen in the collection of Mr. George N. Lawrence, taken in Florida, during the spring of I879. In summer specimens of $M$. griseus, the rufous of the breast blends into white on the abdomen. and the whole is more or less spotted. In the notes, which are so characteristic of all the Limicole, and in the time of its arrival and departure during the spring and fall migrations, it differs essentially from $M$. griseus. The note of $M$. scolopaceus is much louder and clearer, and easily distinguished from the rather plaintive note of $M$. griseus, having about the same relation as the notes of the Big and Little Yellow-leg bear to each other." Mr. Lawrence gives further the memoranda relating to six instances in which he observed the bird on Long Island (in each case singly) from Aug. 7 to Oct. I 3. 
The difference alleged by Mr. Lawrence between the notes of the two birds is confirmed by Mr. G. L. Nicholas, in speaking of the capture of a specimen of scolopaceus on Shinnecock Bay: "The note was entirely different from that of the Dowitcher, being made up of several quick, sharp whistles. I am quite sure it is not a Dowitcher, as it is quite different in color, the under parts being like those of Tringa camutus, and only the throat and sides being spotted. Mr. Lane, with whom I was staying, says that for the past three years he has seen these birds in company with the Dowitchers, and they seem to be increasing in numbers. He and other gunners of the house also say they have never heard this bird give a note anything like that of "the Dowitcher." (Bird-notes from Long Island, in Forest and Stream, xiv, Is8o, p. 44.)

"In regard to the spring arrival of this bird, Mr. George N. Lawrence gives March 20 as the earliest date, he having secured several specimens in Fulton Market, N. Y., at that time, from Long Island, which is about six weeks earlier than any recorded capture of M. grisens. The gunners in the vicinity of Rockaway, L. I., make a distinction between the two birds, calling M. scolopaccus the White-tail Dowitcher, and say it is the first to come in the spring, and during the southern migrations it remains until late in the fall, after the Dowitchers have disappeared." (Bull. Nutt. Club, v, I880, p. I56.)

Dr. Brewer gives $M$. scolopascus full specific rank in his Catalogue (Pr. Bost. Soc., xvii, I875, p. 445), marking it as a rare migrant along the Massachusetts coast, not in company with $M$. grisens, on the authority of Mr. Brewster; but Mr. Purdie corrects this misun. 
derstanding, as Mr. Brewster informed him he found it and griscus together (Bull. Nutt. Club, i, 1876, 73 ). Mr. Allen does not distinguish the supposed species in any way from $M$. griscus (Bull. Essex Inst., x, I878, p 23). Dr. Brewer afterward made the following note: "A female was shot at Eastham, by Mr. Frank L. Tileston, November 2, I878. Without presuming to decide whether this is entitled to rank even as a variety, the fact remains that this bird was a very different form from the common $M$. griseus, and was shot at a period much later than the latter bird has been known to appear" (Bull. Nutt. Club, iv, I879, p. 64). The same record re-appears in Pr. Bost. Soc., xx, I879, p. 272.

The bird had ten years previously been given by Coues as one which should occur in New England (Pr. Essex Inst., v, I868, p. 293). This author in 1874 (B. N. W., p. 477) declined to recognize the species, on the strength of the great variations he found in dimensions among individuals shot from a single flock in Dakota, the differences being supposed to cover both griseus and scolopaceus. But if griseus proper be confined to the Atlantic coast, all his specimens were of course $M$. scolopaccus; and being in fall plumage did not exhibit the color-characters which may distinguish the two forms. His measurements therefore simply show the great range of variation of $M$. scolofaceus in size and proportions. 


\section{STILT SANDPIPER.}

\section{Micropalama himantopus $(B p$.) $B d$.}

Chars. Bill somewhat as in Macrorhamphus, but shorter, less evidently widened at the end, and not so distinctly furrowed. Legs very long; tibix bare an inch ; tarsus as long as the bill; toes semipalmate. Length, 8.50-900; extent, 16.00-17.00; wing, 5.00 ; tail, 2.25 ; bill or tarsus, 1.50-1.70; middle toe and claw, 1.00. Adults in summer: above blackish, each feather edged with white and tawny or bay, becoming scolloped on the scapulars ; auriculars chestnut ; a dusky line from bill to eye, and a light reddish superciliary line; upper tail-coverts white with dusky bars; tail-feathers 12, ashy-gray, their edges and central fields white; under parts mixed reddish, black and whitish, in streaks on the jugulum, elsewhere in bars. Young birds and adults in winter have a dress chiefly ashy above and white below, the sides and jugulum suffused with the color of the back, and streaked with dusky; legs usually pale greenish-yellow.

This very interesting Sandpiper has been the innocent cause of so much contrariety of opinion among New England writers, that it will be well to review the whole case.

Coues included it in I 868 upon presumptive evidence of its occurrence (Pr. Essex Inst., v, I868, p. 294). Specimens had indeed been taken in New England at that date, as at Plymouth and Swampscott, Mass., in 1852 , in 1857 or 1858 , and in I 860 ; but no record had been published.

In his notes on the rarer birds of Massachusetts, Allen cites cases of its occurrence in that state and in New Hampshire (Am. Nat., iii, 1870, p. 639).

A specimen from Needham, Mass., July 24, I87I, is recorded by Mr. O. Fuller (Am. Nat., v, I87 I, p. 727). 
Mr. Brewster soon instanced several specimens from Rye Beach, N. H., and Cape Cod, Mass. (Am. Nat., vi, I872, p. 307.) Mr. Maynard, in Nat. Guide, I870, p. I40, notes Mr. Brewster's first and second specimens, the same as given by Allen, as above. It was in 1870 and 187 I that Mr. Brewster secured the additional specimens, being the ten referred to by him in the American Naturalist, as just quoted; he considered the species as by no means rare.

In his catalogue of 1875 , Dr. Brewer enters the species with the remark: "Migratory, (Mass.)" (Pr. Bost. Soc., xvii, 1875 , p. 445). In reviewing this catalogue, Mr. Purdie speaks, and correctly, as will appear, of the bird as "migratory along the whole New England coast" (Bull. Nuttall Club, i, I876, p. 7.3). To this Dr. Brewer replies: "So far as my own observations go, and so far also as I have been able to obtain information from others, 'H. A. P.' is not warranted in his sweeping statement that Micropalama himantopus is a regular migrant along the whole New England coast. But if he is better posted, and can produce evidence to establish his views on this long controverted point, such data are too valuable and would be too important to be suppressed" (Bull. Nutt. Club, i, IS76, p. 92). Thus put to the proof, Mr. Purdie produces the following in the next number of the periodical cited: "A word about the Stilt Sandpiper (Micropalama himantopus), and I am done. In the 'American Naturalist' (vol, iii, p. 639), is recorded the first supposed instance of its occurrence in New England. In the same periodical (vol. v, p. 727) is given the first supposed ${ }^{*}$ instance for Massachusetts.

* "Mr. F. C. Browne, of Framingham, has a specimen taken at Plymouth in 1852 ." 
Again (in vol. vi, p. 307), Mr. Brewster says: 'The Stilt Sandpiper (Micropalama himantopus), which I see was recorded in a recent number of the Naturalist as new to our Fauna, I consider by no means rare in its migrations. Indeed, I have seen as many as six or seven sent into Boston market at one time, from Cape Cod, and, in the course of a few weeks' shooting in August, at Rye Beach, N. H. (just north of our state limits), I secured no less than ten specimens.' Not only has he since shot it, but he, as well as myself and others, find it frequently in the Boston markets" (Bull. Nutt. Club, ii, I877, p. I7). But Dr. Brewer is still dissatisfied; for he says: 'Having exhausted the all too insufficient limits to which I am restricted, I am compelled to omit nearly all that I have written in reference to Micropalama himantopus. I will only state that in characterizing it as 'migratory, Mass.,' I should have added 'N. H.,' in which it has been taken, twelve miles from our boundary line. Though invited to do so, your correspondent [Mr. Purdie] is unable to give any data to show that it is migratory along the entire New England coast. It has not been found in any part of that coast from St. Andrews to Kittery, or from Buzzard's Bay to East River, and the sweeping statement of your correspondent still remains an entirely unsupported assumption" (Bull. Nutt. Club, ii, I877, p. 48).

Very soon, however, Mr. N. C. Brown comes to the front with the following paragraph: "Mr. H. A. Purdie, in his review of a recent 'Catalogue of the Birds of New England,' stated (this Bulletin, vol. i, p. 73) that Micropalama himantopus is migratory along the whole New England coast. This elicited the rather sweeping 
assertion from the author of the Catalogue, that the bird had 'not been found in any part of the coast from St. Andrews to Kittery' (Bull., vol. ii, p. 48). I desire to contribute my evidence in support of Mr. Purdie's statement. M. himantopus has been repeatedly taken on the marshes and sand-bars in the vicinity of Portland, Me., during the early part of autumn " (Bull. Nutt. Club, iii, 1878 , p. 102).

In an article entitled "Apologetic," Dr. Brewer continues: "My statement that not a specimen of the Micropalama was then known to have been taken along the entire coast of Maine may have been 'sweeping.' It was so intended to be. At the time it was made it was literally and exactly true. Of the occasional and irregular occurrence of this bird in the vicinity of Portland I am well aware (see Proc. Boston Soc. Nat. Hist., Oct. 3, 1877). Its presence at a single point on the western portion of the coast of Maine,* so long as all the rest of the coast is destitute, does not prove either that it is regular in its migrations, or that these extend along the whole New England coast" (Bull. Nutt. Club, iii, I878, p. I48).

On the very page last cited, Dr. Brewer himself gives an interesting note of the bird's abundance in Long Island (and therefore between Buzzard's Bay and East River). It is as follows: "In a late paper read before the Linnæan Society of New York, Mr. N. T. Lawrence speaks of this species as being common on the south side of Long Island (N. Y.). He has quite often, while Bay-Snipe shooting, had parties of from three to five,

* For occurrence eastward of the species, in New Brunswick for example, see Chamberlain, Bull. Nat. Hist. Soc. N. B., 188I, p. 53, and Bull. Nutt. Club, vii, 1882, p. 105. 
and very frequently a single bird or pair, come to his decoys. And, of the four specimens in his collection, two, in adult breeding plumage, were taken in July, the others in fall plumage, in September. This note is interesting as presenting different conditions from any recorded in New England [?]. But one occurrence of this species is known in July, and that in the last part of the month and fifteen miles from the sea. Mr. Geo. N. Lawrence writes me, in reference to the same species, that he lived at Rockaway for five summers, and on one occasion, when he was there, there was a flight of this species and Gambetta flavipes, the latter the most abundant, and of the two species there were killed over one hundred and twenty individuals. He says he remembers killing six of the $M$. himantopus at one shot He never saw so many together as on that day, but all through the season scattering ones were shot "(Bull. Nutt. Club, iii, 1878 , p. 148 ).

Mr. J. Dwight, Jr., next contributes intelligence of several Stilt Sandpipers from New Jersey, July i 5 to Sept. I 5, remarking: "This species will now have been recorded, in numbers, all along the Maine, New Hampshire, Massachusetts, Long Island, and New Jersey coasts, at suitable places from Portland, Me., to Squam Beach, N. J, showing not only that it is a regular migrant, but also that there is every probability of its being taken farther north and farther south. It would now seem that it can hardly be regarded as a rare stragg]er on that part of the Atlantic coast from Maine to New Jersey. The question arises, Has the Stilt Sandpiper been much overlooked, or has it of late years increased in abundance?" (Bull. Nutt. Club, iv, I879, p. 63). 
The same page yields also a note from Dr. Brewer of the capture of a bird of this kind, July 25, 1878, by Mr. Geo. H. Mackay at Nantucket (Bull. Nutt. Club, iv, 1879, p. 63).

Firmness is an admirable quality, but may be excessive. We find the same author presenting the following paragraph, in connection with which he carefully notes very numerous cases of captures: "The past year has brought with it no new fact of any moment, bearing upon the history of this bird, certainly nothing to establish any regularity as a migrant on the New England coast, nor indeed on any part of the Atlantic coast. Throughout Nova Scotia, New Brunswick, and the entire coast of Maine as far west as Portland, it has remained wholly unknown. From Scarboro, Me., to Rye, N. H., we have no record of its having been taken, and from Swampscott, along the entire coast of Massachusetts to Provincetown it continues equally unknown. During the past summer the only record that has reached me of its occurrence was a single specimen procured by Mr. Geo. H. Mackay at Nantucket, July 25, I 878 [as above noted]. This is the second example taken in July in Massachusetts. So far as negative testimony can ever be taken as conclusive, the absence of any data in regard to the presence of this species in any numbers on the New England coast continues to suggest that its regularity as a migrant is still, and more than ever, a thing not proven" (Pr. Bost. Soc., xx, I879, p. 273).

But enough must have been said to convince most persons of the contrary of this. last statement. If not, the reader is referred to Dr. Brewer's very interesting and valuable paper entitled "Notes on the Occurrence of Micropalama himantopus in New England" (Pr. 
Boston Soc. Nat. Hist., xix, I877, pp. 252-256), in which the carefully adduced evidence sustains the contrary of the proposition sought to be maintained. In any event, we have laid before him the evidence upon which he can form his own conclusions, perhaps with needless prolixity. Thus, for example, the species is omitted in Chadbourne's "Rarer Birds of Massachusetts," as too common to require comment (Quart. Journ. Bost. Zool. Soc., i, I882, p. 4). We may finish with the remark upon the bird's general habitat made by Coues in the "Key to North American Birds" : "North America, generally dispersed but apparently not very common anywhere ; West Indies, in winter; U. S. during the migrations; breeds in high latitudes." The habits are much like those of Macrorhampluzs.

\section{SEMIPALMATED SANDPIPER.}

Ereunetes pusillus (L.) Cass.

Chars. Feet semipalmate, with two evident webs. Bill, tarsus, and middle toe with its claw of approximately equal lengths, an inch or less long, but bill apt to be shorter, even down to 0.75 or 0.67. Length, 5.50-6.50; extent, Ir.75; wing, 3.25-3.75; tail, 2.00, doubly emarginate, the central feathers projecting. Adult in summer: upper parts variegated with black, bay, and ashy or white, each feather with a black field, reddish edge, and whitish tip; rump and most upper tail-coverts blackish. Tail ashy, the central feathers darker; primaries dusky, the shaft of the first white. A dusky line from bill to eye, and white superciliary line. Below, white, usually rufescent on the breast, with dusky speckling on the throat, breast, and sides. In winter the upper parts mostly plain ashy-gray. Young in July and August has scarcely any traces of spots beneath, being then almost entirely white, with a wash of buff across the breast. 
An abundant spring and autumn migrant, along the coast, thronging the beaches at those seasons in flocks numbering hundreds and even thousands. The usual periods of the passage are April and September; but it appears in August, and a few indivicluals are to be seen during the summer. Though this does not prove that it breeds with us, there is some additional evidence that it occasionally does so. Thus Mr. Merriam notes the egg of a Sandpiper, believed by Dr. Brewer to be this species, taken at Bradford, Conn., July 20, I 877 , by Mr. Walter R. Nichols (Rev. B. Conn., I877, p. 105).

In general habits, this species Fig. 49.- Foot of closely resembles Tringa minutilla, Natural size. and the two are often found flocking together.

A very large series of the eggs of Erennetes shows the variations probably always observable when great numbers of any limicoline wader's eggs are examined. Some of them are nearly like the Buff-breasted Sandpiper's eggs described beyond, and such appears to be the normal pattern. Others, however, are quite different. One variation affects the ground-color, which, instead of being clay colored (very pale grayish or greenish-drab), is decidedly olivaceous; and in these eggs the markings are correspondingly heavy, rather umber-brown than chocolate. In another decided variety the markings, instead of being bold blotching, massed at the large end, are exceedingly fine dotting, uniform over the whole $\mathrm{egg}$, drawn like a veil, as it were, over the ground, giving the predominant complexion to the egg. The following are several measurements : 1.22 by $0.84 ; 1.25$ by $0.83 ; 1.20$ by 0.85 . The 
sets, complete, contain three or four eggs; those with one or two are presumably incomplete. All that I have seen were collected in Arctic America. According to the labels, the nests are, as usual for those of small waders, depressions in the ground, generally in or near marshy tracts, and lined with a few dried leaves or grasses.

\section{LEAST SANDPIPER.}

\section{Actodromas minutilla $(V)$ Coues.}

Chars. Smallest of the Sandpipers; length, 5.50-6.00; extent about I I.00; wing, 3.25-3.50; tail, 2.00 or less; bill, tarsus, and middle toe with claw, about 0.75 . No webbing between toes. Bill black; legs dusky-greenish. In summer, upper parts with each feather blackish centrally, edged with bay, and tipped with ashy or white; in winter, and in the young, simply ashy. Quills of wing blackish, the shaft of the first primary white, the secondaries and greater coverts tipped with white. Crown not conspicuously different from the hind neck; an indistinct whitish line over eye and dusky line from bill to eye. Below, white, the jugulum and sides of body with an ashy or brownish suffusion, thickly spotted and streaked with dusky.

This species and the last are often confounded under the name of "peeps," but a glance at the toes suffices to distinguish them. It is an abundant migrant during the latter part of April and in May, and again in August and September. It is not known to breed with us, though individuals may be seen at times during the summer. Dr. Coues draws the following picture of the summer home of the birds in Labrador.

"Fogs hang low and heavy over rock-girdled Labrador. Angry waves, palled with rage, exhaust them- 
selves to encroach upon the stern shores, and baffled, sink back howling into the depths. Winds shriek as they course from crag to crag in mad career, till the humble mosses that clothe the rocks crouch lower still in fear. Overhead the Sea Gulls scream as they winnow, and the Murres, all silent, ply eager oars to escape the blast. What is here to entice the steps of the delicate birds? Yet they have come, urged by resistless impulse, and have made a nest on the ground in some half-sheltered nook. The material was ready at hand, in the mossy covering of the earth, and little care or thought was needed to fashion a little bunch into a little home. Four eggs are laid (they are buffy-yellow, thickly spotted over with brown and drab), with the points together, that they may take up less room and be more warmly covered; there is need of this, such large eggs belonging to so small a bird. As we clraw near, the mother sees us, and nestles closer still over her treasures, quite hiding them in the covering of her breast, and watches us with timid eyes, all anxiety for the safety of what is dearer to her than her own life. Her mate stands motionless, jut not unmoved, hard by, not venturing even to chirp the note of encouragement and sympathy she loves to hear. Alas! hope fades and dies out, leaving only fear; there is no further concealment - we are almost upon the nest-almost trodden upon she springs up with a piteous cry and flies a little distance, re-alighting, almost beside herself with grief; for she knows only too well what is to be feared at such a time. If there were hope for her that her nest were undiscovered, she might dissimulate, and try to entice us away by those touching deceits that maternal love inspires. But 
we are actually bending over her treasures, and deception would be in vain; her grief is too great to be witnessed unmoved, still less portrayed; nor can we, deaf to her beseeching, change it into despair. We have seen and admired the home - there is no excuse for making it desolate; we have not so much as touched one of the precious eggs, and will leave them to her renewed and patient care.

"This is one verse in the little Sand-bird's life, with the wolf at the door of what would seem the perfect security of an humble home. Now later in the season, when the young birds are grown strong of wing, family joins family, and the gathering goes to the sea-beach. Stretches of sand, or pebbly shingle, or weed-loaded rocks, or muddy flats bestrewn with wrack, invite, and are visited in turn; and each yields abundant sustenance. The unsuspecting birds ramble and play heedlessly in the very front of man, unmindful of, because unknowing, danger; they have a sad lesson to learn the coming winter, when they are tormented without stint, and a part of their number slaughtered in more civilized countries for mere sport, or for the morsel of food their bodies may afford. Blasts fiercer than they ever knew before come out of the north; autumn is upon them, and they must not wait. Flocks rise on wing, and it is not long before the beaches and the marshes of the States are thronged." (Birds Northwest, 1874, p. 483.) 


\section{BAIRD'S SANDPIPER.}

\section{Actodromas bairdi Coules.}

Chars. Adult male. Bill wholly black, small and slender, slightly shorter than the head, just as long as the tarsus or as the middle toe and claw, slightly expanded or lancet-shaped at the end, the point acute; grooves long, narrow, deep; feathers on side of lower mandible evidently reaching further than those on upper. Upper parts brownish-black (deepest on the rump and middle upper tail-coverts, and lightest on the neck behind) each feather bordered and tipped with pale brownish-yellow, the tipping of the scapulars broadest and nearly white, their margining broad and brightest in tint, making several deep scollops toward the shafts of the feathers. Only the outer series of upper tailcoverts on each side varied with whitish. Middle tail-feathers brownish-black, the others plain gray, with paler margins. Jugulum tinged with light dull yellowish-brown, spotted and streaked with illy-defined blackish markings, as are also the sides under the wings. Throat and the other under parts white, unmarked. Feet black, like the bill. Length, 7.25 ; extent, I 5.25 ; wing, 4.90 ; bill, 0.85 ; tarsus, and middle toe and claw, the same. The female is entirely similar, but slightly larger. The young have the upper parts wholly light brownish-ash, clarker on the rump, and all the feathers with a dark field, and pale or whitish edging; waves of brownish-black on the scapulars. Jugulum and breast suffused with dull light reddish-brown; the spotting small, sparse, and very indistinct. Actodromas bonapartii is a little larger on the average; the bill noticeably stouter, flesh-colored at base below; the feathers on the sides of the lower mandible do not extend noticeably beyond those on the upper; the scapular edging is bright chestnut; the jugulum is white, or barely perceptibly ashy, with numerous narrow, distinct streaks; and the upper tail-coverts are white. A. bairdi is exactly intermediate in size between $A$. maculata and $A$. minutilla, and is almost identical with the latter in pattern of coloration, but the markings on the breast are not thick and heavy, and the edgings of the scapulars not bright chestnut. The species scarcely 
requires comparison with maculata; the latter is much larger; it differs in the colors and proportions of the bill; the pattern (plain, unscolloped) of coloration of the scapular edgings; the abrupt transition from the color of the crown to that of the hind neck; the heavy pectoral markings, etc.

This species was originally described from the west. It was not until 1870 that it was known to occur on the Atlantic coast. Mr. H. W. Henshaw took a specimen on Long Island in Boston Harbor, Aug. 27, I870, as recorded by Mr. Brewster in Am. Nat., vi, I872, p. 306. Mr. Brewster also notes a specimen which he secured at Upton, Oxford Co., Me., Sept. I, I 875 (Bull. Nutt. Club, i, 1876, p. I9). August I 7, i 876 , another was taken, by Mr. Wm. A. Jeffries, at Swampscott, Mass. (Brewer, Bull. Nutt. Club, iii, I878, p. I40). Mr. N. C. Brown records the only known case for the Maine coast, a young male, in company with another, shot by his brother on Scarborough Beach, Sept. 9, I 875 (Bull. Nutt. Club, ii, I 877, p. 28).* Dr. Brewer instances the capture of a specimen by Mr. Wm. A. Jeffries, at at Swampscott, Mass., Aug. 27, I876 (Bull. Nutt. Club, iii, I 87 S, p. I 40).

To these four cases (two for Maine, two for Massachusetts), Mr. Brewster has latterly added his experiences with several Baird's Sandpipers at the mouth of Cambridge River, Oxford Co., Me., where he secured several specimens, which were in company with Semipalmated Sandpipers and Ring-neck Plovers. "Their motions were slow and sedate, and their attitudes crouching. They kept up a low conversational twitter

* This specimen is erroneously recorded as "Ancylocheilus subarquatus" by Dr. Brewer in Pr. Bost. Soc. Nat. Hist., xix, I878, p. 307. 
while feeding, and when flushed, flew in that swift, erratic way characteristic of most of the smaller Waders. The peculiar coloring of the upper parts gave them a striped appearance, which should serve to distinguish them from any other eastern Sandpiper excepting Tryngites mufescens" (Bull. Nutt. Club, vi, i881, p. 60).

The first New Hampshire record is given by Mr. H. M. Spelman, who obtained two specimens at Rye Beach, N. H., Aug. 26, I880 (Bull. Nutt. Club, vi, I88I, p. 6I).

Our esteemed correspondent, Mr. Purdie, advises us of further notes on this species, which we have had no opportunity of looking up. These are: Quart. Journ. Bost. Zool. Soc., i, I882, p. 3 I ; Maynard's Birds E. N. A., p. 38I; and the Ornithologist and Oologist, vii, I882, p. I33 - the latter reference being to Central New York.

This Sandpiper is only known to breed in high latitudes. Eggs are described by Coues as having the ground clay color, tending in some cases to gray, in others to buff; the spotting rich umber and chocolatebrown of varying shade or depth, with the usual paler shell-markings. In most instances the markings are fine and innumerable, of indefinite size and shape, though thickest and largest at the greater end, where occasionally massed in large blotches. Specimens measurc: $1.30 \times$ $0.90 ;$ 1. $35 \times 0.94 ; 1.28 \times 0.90$. 


\section{PECTORAL SANDPIPER; GRASS SNIPE; JACK SNIPE.}

\section{Actodromas maculata $(V$. Cones.}

Chars. Form exactly as in $A$. minutilla; coloration much the same ; size much larger ; length, 9.00-9 50 ; extent, 16.50-18.00 ; wing averaging 5.50 ; bill, tarsus, and middle toe with claw, each, 1.Io. Bill and feet dusky greenish. Crown streaked with brownish-black and light chestnut, different from the neck behind, which is streaked with dusky and light ochrey. Upper parts brownish-black, each feather edged with dusky or chestnut, the latter brightest on the scapulars, not making indentations toward the shaft. Rump and most upper tail-coverts blackish, the internal ones white with dark spots. Primaries blackish, the shaft of the first white, of the others brown. Under parts white, the jugulum and fore breast with a heavy wash of ashybrown, and numerous dusky streaks.

The Pectoral Sandpiper is a common migrant through New England, especially in the autumn. It arrives from the north in August, sometimes early in that month and soon makes its way south, to return in April or May. In habits it is rather Snipe-like than like a Sandpiper, as it does not flock on the sandy beaches, but rather frequents wet, grassy meadows, muddy pools and flats, and the salt-marshes. It is, however, oftener seen along the coast than inland. It is very abundant in summer in Labrador, where it frequents low, muddy flats, laid bare by the tide, and the salt-marshes adjoining. When they arise from the grass to alight again at a little distance, they fly in silence or with a single treet, holding the wings deeply incurved; but when suddenly startled and much alarmed, they spring quickly, with loud, repeated cries, and make off in an irregular manner, much 
like the common Snipe. Sometimes, gaining a consider. able elevation, they circle for several minutes in silence overhead, flying with great velocity, perhaps to pitch down again nearly perpendicularly upon the same spot they sprang from. The southward migration begins in August, and is usually completed by the following month.

\section{BONAPARTE'S SANDPIPER; WHITE- RUMPED SANDPIPER.}

\section{Actodromas bonapartil (Schl.) Cones.}

Chars. In form like the other species of Actodromas. Size intermediate between $A$. maculata and $A$. minutilla, about the same as in $A$.bairdi; length, 7.50 ; extent, 15.00 ; wing, 4.75 ; bill, tarsus, and midrle toe with claw rather less than r.oo. Upper tail-coverts white; a strong character, peculiar to this species in the genus. Upper parts generally, including the crown, light brownish-ash, each feather with a large field of dusky toward the end, and on the crown and middle of the back edged with light yellowish-red, deepening into sienna-red on the scapulars. Primaries dusky, their shafts white centrally. Rump brownish-black. Central tail-feathers the same, the lateral ones grayish-ash, edged and tipped with white. Under parts white, the jugulum and breast with a faint ashy wash, and numerous linear oblong spots of clusky. Young in August chiefly ashy on the upper parts, the markings of the jugulum less distinct.

This is another of New England's abundant Sandpipers, flocking along the beaches during the migrations, which occur at the same seasons as those of the other species. It breeds abundantly in Labrador and other northern regions. 


\section{PURPLE SANDPIPER.}

\section{Arouatella maritima (Brïnn.) Bd.}

Chars. In form, differing from other Sandpipers in the shortness of the legs; tarsus shorter than micldle toe and claw, or than bill; tibia feathered to the suffrago; bill not quite straight. Length about 900; extent about 16.00 ; wing, 5.00 ; tail, 2.60 , much rounded; bill, I.20 ; tarsus, 6.80-0.90; middle toe, I.00, or a little more. In breeding-dress: Crown streaked with yellowish-gray or grayish-white; scapulars and interscapulars indented with dull buff or whitish, and tipped with white; foreneck distinctly streaked with dusky; breast dull gray, spotted with darker. In winter: Back and scapulars sooty-blackish glossed with purplish, the feathers bordered terminally with dark plumbeous-gray; foreneck uniform mouse-gray, or brownishplumbeous. Rest of under parts white.

The Purple Sandpiper is a species of circumpolar distribution, breeding only in the high north, as far as polar explorers have gone, and migrating to temperate lattiudes for the most part, though all individuals of the species do not forsake the forbidding regions of their birth even during the most inclement season. In New England it is chiefly and properly a winter resident, making its appearance after other migratory Sandpipers, late in the fall, and remaining until the spring is fairly advanced. It is not nearly so abundant as some of the species, and is chiefly to be found singly or by twos and threes, or in small flocks, on rocky shores. Hence it is often called "rock" snipe or "rock plover." It also merits its scientific name, maritima, as it is seldom if ever found inland. The eggs, four in number, measuring about $1.40 \times 1.00$, are of the usual pyriform shape, of clay-colored ground with an olive shade, boldly marked 
with a rich umber-brown of varying tint, and neutral shell-markings, which appear over the whole surface, but are largest and most massed at the greater end.

\section{RED-BACKED SANDPIPER.}

\section{Pelidna alpina americana (Cass.) Coules.}

Chars. Bill longer than head or tarsus, compressed at base, rather depressed at the end, usually appreciably decurved. Length, 8.00-9.00; extent, I5.00 ; wing, 4.50-5.00 ; tail, 2.00-2.30 ; bill, 1.50-1.75; tibiæ bare about 0.50 ; tarsus, 1.05 ; middle toe and claw, 0.95. Adult in summer: Above, chestnut-red, each feather with a central black field, and most of them tipped with whitish ; rump and upper tail-coverts blackish; tail-feathers and wingcoverts ashy-gray, the greater coverts tipped with white. Under parts white; the belly with a broad, jet-black area, the breast and jugulum streaked with dusky. Bill and feet black. Adult in winter, and young: Above, plain ashy-gray, with dark shaftlines, with or without red or black traces. Below, white, with little or no trace of black on the belly; jugulum with a few dusky streaks and an ashy suffusion.

Chiefly a spring and autumn migrant, though occasionally observed at other seasons. It is a common

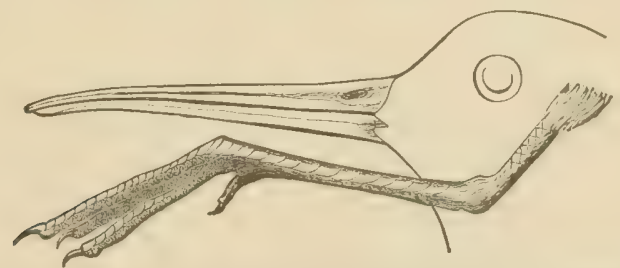

Fig. 49. - Bill and Foot of Red-backed SANdpiper. Natural size.

bird coastwise, in flocks on the beaches with others of its tribe, but rarely found inland. Mr. C. J. Maynard 
speaks of taking it late in November, and a few individuals doubtless winter with us. The same observer took it June I8, I868, about a fresh-water pond near Ipswich; but this date is exceptional. At Calais, Me., Mr. Boardman records its presence in August and September. In Mr. Allen's Catalogue of I 878 it is marked for Massachusetts as an abundant migrant, with the observation that a few sometimes remain in summer (Bull. Essex Inst., $\mathrm{x}$, r 878, p. 24). There is no evidence that it breeds in New England.

\section{CURLEW SANDPIPER.}

\section{Ancylochilus subarquatus (Güld.) Kaup.}

Chars. Bill much longer than head, very slender, decurved; legs long; tibix bare for about half the length of the tarsus. Adult: crown of head and entire upper parts greenish-black, each feather tipped and indented with yellowish-red; wing-coverts ashy-brown, each feather with dusky shaft-line and reddish edging. Upper tail-coverts white, with broad, dusky bars, tinged at their extremities with reddish. Tail pale gray, with greenish reflections. Sides of neck and entire under parts uniform deep brownish-red; under tail-coverts barred with dusky; axillars and under wing-coverts white; bill and feet greenish-black. Young: Crown of head and upper parts brownish-black, with slight greenish lustre, each feather edged with white or reddish-yellow; rump plain dusky; upper tail-coverts white; wing-coverts with broad, grayish-white borders. Under parts white, the breast and sides of the neck with fine dusky streaks; the former with a light buff tinge. Length, 8.50 ; wing, 4.90 ; bill averaging I.50; tarsus, I. 30 ; middle toe and claw, 0.90 ; tibia bare 0.70 .

This is an Old World Sandpiper, so rare everywhere in North America as to be properly considered little more 
than a straggler in this country. Audubon regarded its occurrence as accidental. Nevertheless, it has been several times observed in New England, and we have taken the pains to look up the record of these occurrences, concerning which a singular confusion appears to have possessed the minds of several writers.

The name occurs in the Rev. Mr. Linsley's Connecticut list of I843, but without sufficient data. This record is discredited by Dr. Merriam, and may be passed over, though very likely quite correct, as too indefinite for citation.

In I862, Mr. G. A. Boardman includes the Curlew Sandpiper in his list of Calais (Maine) birds, with only the remark, "not very plenty." (Pr. Bost. Soc., ix, I 862 , p. I 28.)

In $1867, \mathrm{Mr}$. E. A. Samuels refers to the capture of the Curlew Sandpiper on Cape Ann, Mass., in 1865 (Orn. and Oöl. of New England, r 867, p. 444). "This is undoubtedly the most rare of all our shore birds. I found a single specimen in a bunch of Sandpipers shot on Cape Ann, in the autumn of 1865 , for sale in the principal market. This is the only instance that has come to my knowledge of its being found here. Audubon speaks of two; and other writers of a few more in different years." This is the earliest definite record we have, although, as we shall see presently, the bird had really been taken in New England long before.

Coues, in 1868 , includes the species on the strength of Samuels' example, calling it "very rare," and stating that it is seen chiefly during the migrations. He also adds, that "the species is in America hardly more, perhaps, than a visitor from Europe." (Pr. Essex Inst., v, I868, p. 293.) 
In I870, Mr. C. J. Maynard speaks of "a few specimens taken on our Massachusetts coast," but gives no particulars. (Naturalists' Guide, I870, p. I40.)

In 1875, Dr. T. M. Brewer makes the following remark: "This is an European species, of rare and accidental occurrence in America. Up to the present time no authenticated instance was on record of a single specimen having been taken in any part of New England. It had been given on the strength of three individuals taken at St. Andrews, N. B., on the St. Croix, and within a few miles of the Maine line. A single individual has recently been taken at Ipswich, Mass., and the same is now in the collection of Raymond Newcomb, of Salem (Pr. Bost. Soc, xvii, I875, p. 446)." This ignores Mr. Samuels' record, and discredits Mr. Maynard's remarks. * The New Brunswick examples mentioned are those adduced by Mr. G. A. Boardman as of Maine (Pr. Bost. Soc., ix, I862, p. I28).

In $1876, \mathrm{Mr}$. Wm. Brewster, in a note entitled "Occurrence of the Curlew Sandpiper in Massachusetts," gives the following account: "Mr. Charles I. Goodale, an accomplished Boston taxidermist, has a fine Curlew Sandpiper (Tringa subarquata) which was sent to him to be mounted. It was shot in East Boston, Mass., early in May, 1876, as it was feeding on a sand-spit among a flock of 'peeps.' This bird, in very perfect spring plumage, furmishes the second authentic instance of the occurrence of this species in New England." (Bull. Nutt. Club, i, I876, p. 5 I.) In calling it the "second

* Another example of confusion on the part of this writer is found in Pr. Bost. Soc., xix, 1878, p. 307, where Dr. Brewer records the Scarboro' specimen of Actodromas bairdi (mentioned above, p. 218) as one of Ancylochilus subarquatus. 
instance, however," Mr. Brewster appears to have been misled by Dr. Brewer's note above quoted. It was really the third.

In I877, Mr. C. H. Merriam comes forward with a specially interesting and valuable notice of the Curlew Sandpiper in Connecticut. (Rev. B. Conn., p. I06.) We transcribe it in full : "A rare visitor along our coast. $\mathrm{Mr}$. Josiah G. Ely writes me that one was shot near Saybrook, many years ago, and I am informed by Dr. D. Crary, of Hartford, that a specimen of this species was killed, Oct. 3, I859, at Keeny's Cove, on the Connecticut River, in East Hartford (Hockanum), Conn. Also, Dr. E. L. R. Thompson, of this city, tells me that he shot three Curlew Sandpipers on the Quinnipiac River (near New Haven) in June, I874. Dr. Wm. O. Ayres, now of Easthampton, Long Island, writes me that he 'killed it once at Miller's Place, L. I., in I839,' and it has also been taken in Massachusetts." Aside from the Long Island instance, this gives us three occurrences, of five specimens, for Connecticut alone.

In I879, Mr. R. Deane gives "Additional Captures of the Curlew Sandpiper in New England" (Bull. Nutt. Club, iv, 1879, p. I24): "The three * specimens of this rare straggler, which have been previously recorded as occurring in New England, have all been collected in Massachusetts, and I am enabled to add two more instances, both of which have been taken in this State. Mr. John Fottler, Jr., writes me that he has in his pos-

* The "three" here meant are those above noted, viz. : Samuels' Cape Ann one, Brewer's Ipswich one, and Brewster's East Boston one. This makes Deane's two additional examples the fourth and fifth; but as he overlooks Merriam's record, his specimens are really the ninth and tenth. 
session a fine spring specimen, which was shot on Cape Cod about the Ioth of May, I878. Another specimen is in the collection made by-Mr. Baldwin Coolidge (now in possession of the city of Lawrence, Mass.), which was taken on Nahant Beach some ten years ago, and at that time was preserved by Mr. N. Vickery, of Lynn."

Thus, overlooking all accounts not accompanied by the particulars, there would appear to be at least ten well authenticated instances of the occurrence of the Curlew Sandpiper in New England, aside from those in New Brunswick and Long Island, and about a dozen individuals appear to have been actually taken within our limits.

\section{RED-BREASTED SANDPIPER; ASH-COLORED SANDPIPER; ROBIN SNIPE; KNOT. \\ TRINGA CANUTUS Linn.}

Chars. Largest of the Sandpipers; length, 10.50; extent, 20.50; wing, 6.40 ; tail, 2.75 ; bill, 1.40 ; tarsus, 1.20 ; middle toe and claw 1.00. Adult in summer: Above brownish-black, each feather tipped and edged with ashy-white, tinged with reddishyellow on the scapulars; rump dark ash, barred with dusky; upper tail-coverts white, with sagittate or crescentic dark bars. Tail grayish-ash, edged with ashy-white. Line over eye and entire under parts brownish-red, fading into white on the flanks and crissum, the latter with sagittate dark marks. Bill and feet greenish-black. Young: Above, uniform dark ash, with a conspicuous set of black and white semicircles, very characteristic of the species; under parts white, more or less tinged with reddish, the throat, breast, and sides with dark marks.

This large and handsome species, remarkable for its seasonal differences of plumage, but in any state readily 
distinguished from its congeners, is a common spring and autumn migrant through New England, where it is found chiefly in small flocks along the seashore. According to Mr. Merriam it has been observed in Connecticut, near Middletown, "in summer;" but this probably means late in that season, and does not imply that the bird ever passes the whole summer with us. Mr. Boardman speaks of its appearance in Maine in August and September. It usually arrives the latter part of August, remaining for a couple of months, and reappears in April and May.

\section{SANDERLING; RUDDY PLOVER.}

\section{Calidris arenaria (L.) Illig.}

Chars. Readily distinguished from any other Sandpiper by having no hind toe, like a plover. Entire upper parts and neck all around variegated with black, light ashy and bright-reddish. Under parts white, immaculate. Winter and young birds with little if any trace of the reddish, the upper parts being regularly mottled with blackish and whitish, the under parts white. Bill and feet blackish. Length, 7.50-8.00; extent, I 5.00-16.00; wing, 4.90 ; tail, 2.25 , bill about 1.00 ; tarsus rather less; middle toe and claw 0.75 .

The "Beach-bird," as this species is called by the gunners, is one of the most abundant of its tribe in New England during the vernal and autumnal migrations. It also occurs, though more sparingly, in winter, and Mr. Verrill found it abundant in summer on the coast of Maine, where he was of opinion it might breed. We have, however, no sufficient evidence that it does so, and in fact the probability is the other way; for the 
Sanderling is only known to nest in high latitudes. This seems to be a case like that of our other Sandpipers, stragglers of nearly or quite all of which may be found along our coast in summer, though not breeding within our limits. The present species is extremely abundant on the pebbly and sandy beaches in the autumn, becoming numerous in September, and so continuing through the following month.

\section{GREAT MARBLED GODWIT.}

Limosa feeda (L.) Ord.

Chars. Feathers not extending on side of lower mandible far beyond those on upper. No white anywhere ; rump, tail and its coverts barred throughout with blackish and the body-color. Lining of wings and axillars chestnut, more or less barred with black. General color rufous or light dull cinnamon-red, nearly uniform on the under parts, richer on lining of the wings, on the whole upper parts variegated with the brownish-black field of each feather, the blackish predominating, leaving the rufous chiefly as scollops and tippings of the feathers. Bill livid flesh-color, blackish on about the terminal third; feet ashy-blackish. Length, 16.00-22.00; extent, 30.00-40.00; wing somewhere about 9.00, bill, 3.50-5.50, generally about 4.00; tarsus about 3.00 .

This is the largest of the "Bay-birds," excepting the great Curlew, and no less conspicuous by its reddish "color-line" than by its size. It may easily be dis- 
tinguished from a Curlew by the fact that the bill is either straight, or bent a little upward, - not decurved. It does not appear to go far northward along the Atlantic coast, where it is not common beyond the Middle States; being, in fact, a rare bird in New England. It inhabits muddy estuaries and marshes, usually in flocks of greater or less extent.

The eggs of this Godwit, not as yet well-known, are described by Coues in the following terms:--

"The only perfect set of eggs of the Godwit I have seen were taken June I, I87I, fifty miles northwest of Saint Paul, Minnesota; both parents were secured and deposited in the Saint Paul Academy, where I examined them; so that the identification is unquestionable. There are three eggs in this set, measuring $2.30 \times$

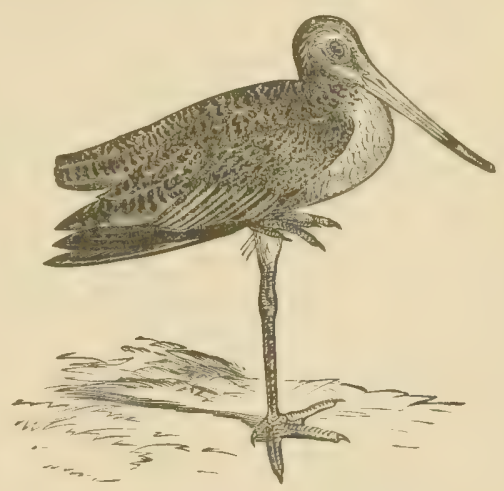

Fig. 51,-Great Marbied Godwit. I. $60,2.28 \times 1.56$, and $2.26 \times 1.62$. The color is a clear, light olivaceous-drab; the markings are small and numerous, but not very strongly pronouncedthere is nothing (in this set) of the heavy blotching and marking usually seen in waders' eggs. The spots are pretty evenly distributed, though rather larger in two instances, and more numerous in the other instance, about the butt than elsewhere. These markings are of various umber-brown shades, with the usual stone-gray shell spots." 


\section{HUDSONIAN GODWIT.}

\section{Limosa himastica (Limm., I758.) Coues.}

Chars. Feathers on side of lower mandible reaching to a point far in advance of those on upper mandible. Rump blackish. Most of the upper tail-coverts white; longest coverts and the tailfeathers black with white bases, the tail-feathers also white tipped. Lining of wings sooty-blackish, mixed with some white; axillars black. Under parts rich chestnut-red, crossed everywhere with numerous irregular black bars, there being several on each feather, and usually also crossed with similar white bars, especially behind. Upper parts blackish with a greenish gloss, intimately mixed with rufous and whitish. Bill light-colored, dark on the terminal third. Length, 14.00-16.50; extent, 24.0026.50; wing, 7.50-8.50; tail, 3.00-3.50; tarsus, $2.25-2.55$.

This smaller Godwit, the American representative of the European Black-tailed Godwit, Limosa agoccphala, will be readily distinguished from the foregoing by the above characters. Young and winter specimens differ a good deal in general body colors, but the specific characters of the wings and tail are much the same. The species is more frequently seen in New England than the Great Marbled Godwit, and in some seasons is to be fairly called common; but it is somewhat irregular in its movements, and more or less locally distributed. Dr. Brewer notices one shot on Cape Cod in November, I 878 (Bull. Nutt. Club, iv, I879, p. 64), but this is doubtless exceptional. The breeding resorts are entirely beyond our limits, in hyperborean regions. A set of four eggs in the Smithsonian, from Anderson River, where they were secured by Mr. MacFarlane, June 9, measure 2.15 to 2.20 in length by about 1.40 in breadth. The ground is a very heavily shaded olive- 
drab, much darker (almost as in a Loon's or Jäger's egg) in two of the specimens than in the other. In these darker specimens the markings are almost lost in the general heavy color, merely appearing a little darker; they are chiefly evident at the greater end. In the other the markings, of the same general character, are, however, much more conspicuous, owing to the lighter ground. The peculiar coloration of the bird has given rise to the name "spot-rump," by which it is known to sportsmen.

\section{SEMIPALMATED TATTLER; WILLET.}

\section{Symphemia semipalmata $(G m$.) Hartl.}

Chars. Toes semipalmate; a web of some size between the inner and middle as well as between the outer and middle; bill stout for this family. Above, in summer, ashy speckled with dusky, sometimes with slight rufescence. Under parts white, sometimes with slight rufescence, the throat and breast spotted and streaked with dusky, the sides banded or arrow-headed with the same, the axillars and lining of wings, and edge of wing and primary coverts, blackish; a great white space on the wings partly overlaid by the coverts. Tail ashy, incompletely barred with blackish, its coverts mostly white. Bill dark; legs blue. Young, and in winter, chiefly plain ashy above and white below. Length about 16.00 ; wing, 8.00 ; tail, 3.00 ; bill, 2.50 ; tarsus the same.

This large, stout Tattler, known at a glance by its white-mirrored, black-lined wings and blue legs, is one of the few species of the great family Scolopacide which regularly and plentifully summer in some portion of New England, though more frequently observed during spring and fall than at any other season of the year. 
The nest is placed near the water of some secluded pool, or in the midst of a marsh, whether fresh or salt, in a tussock of grass or rushes. It is a rude structure, of the simplest materials, raised a little way from the ground, and with a shallow indentation. The eggs are very variable in all respects. As to size and shape, the following measurements show the differences: $1.90 \times$ $1.45 ; 1.95 \times 1.50 ; 2.00 \times 1.50 ; 2.05 \times 1.55 ; 2.12 \times$ I.50; averaging about $2.00 \times 1.50$. They are less pointedly pyriform than the eggs of the smaller Tattlers

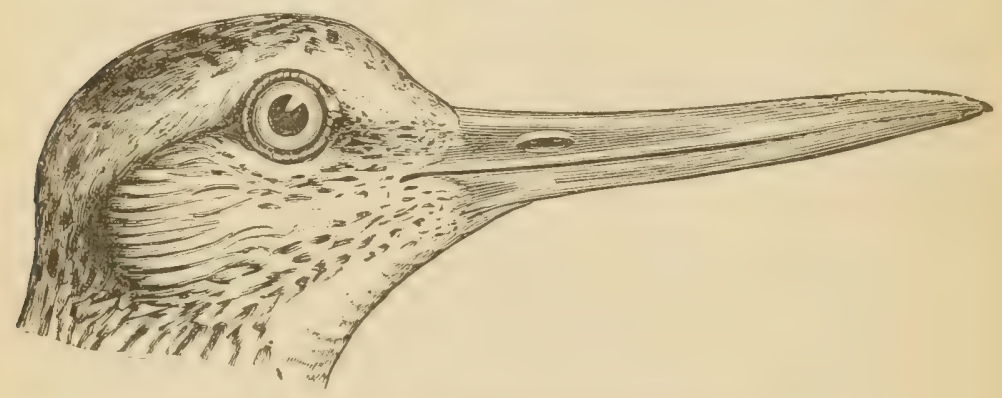

Fig. 53.- IIEAD of Wili.et. Natural size.

and Sandpipers. The ground is sometimes brownisholive, or drab, or clay-color; sometimes, again, quite buffy-brown; in a few cases greenish or grayish-white. The spotting is bold and distinct, but little massed even at the greater end, where, though the spots are largest and most numerous, they generally remain distinct. The spots are mostly clean-edged and sharp, of moderate size, but sometimes quite fine and scratchy. They are of various umber-brown shades, and accompanied with the usual obsolete shell-markings.

Under ordinary circumstances Willets are notoriously restless, wary, and noisy birds; but their nature is 
changed, or, at any rate, held in abeyance, during and for a short time after incubation. They cease their cries, grow less uneasy, become gentle, if still suspicious, and may generally be seen stalking quietly about the nest. When Willets are found in that humorabsent-minded, as it were, absorbed in reflection upon their engrossing duties, and unlikely to observe anything not directly in front of their bill - it is pretty good evidence that they have a nest hard by. It is the same with Avocets, and probably many other waders. During incubation the bird that is "off duty" (both parents are said to take turns at this) almost always indulges in revery, doubtless rosetinted, and becomes in a corresponding degree oblivious to outward things. If then they are not set upon in a manner entirely too rude and boisterous, the inquiring ornithologist could desire no better opportunity than he will have to

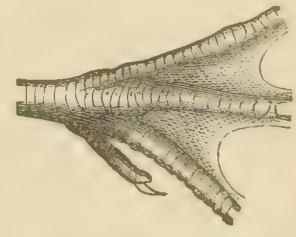

Fig. 53. - Semipalmated TOES of Willet. Natural size.

observe their every motion and attitude. But once let them become thoroughly alarmed by too open approach, particularly if the setting bird be driven from her nest, and the scene quickly shifts; there is a great outcry, violent protest and tumult, where was quietude. Other pairs, nesting near by, join their cries till the confusion becomes general. But now, again, their actions are not those they would show at other times; for, instead of flying off with the instinct of self-preservation, to put distance between them and danger, they are held by some fascination to the spot, and hover around, wheeling about, flying in circles a little way to return again, with unremitting clamor. They may be only too easily 
destroyed under such circumstances, provided the ornithologist can lay aside his scruples and steel himself against sympathy.

\section{GREATER TATTLER; GREATER YELLOW- LEGS ; STONE SNIPE.}

\section{Totanus melanoleucus (Gm.) Vicill.}

Chars. Bill slender, longer than head, straight or slightly bent upward, black or blackish; legs very long, yellow. Above blackish, more or less ashy according to season, everywhere speckled with whitish, in a series of indentations along each feather. A slight white superciliary line; upper tail-coverts mostly white. Under parts white, the jugulum, breast, and sides with dark streaks or bars. Length, 13.50 ; extent, I 4.00 ; wing over 7.00 , nearer 8.00 ; tail, 3.00 or more ; bill, 2.00 or more.

This large and elegant Tattler, well-known to gunners, is a common species in New England during the

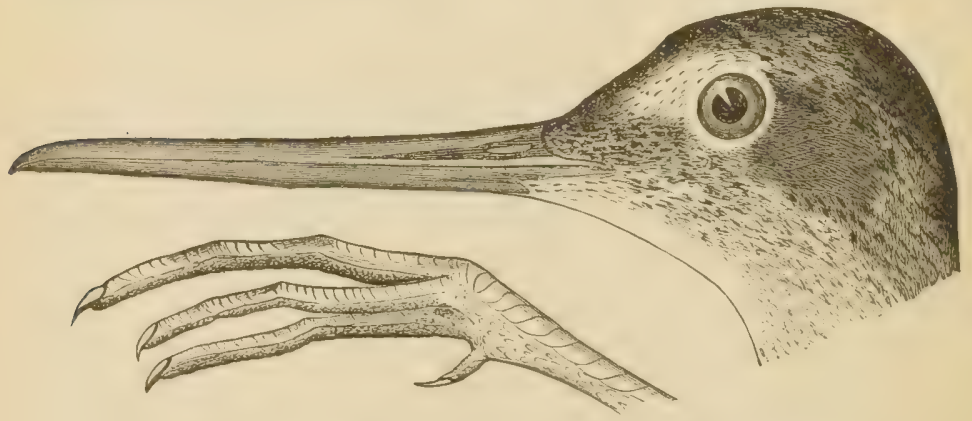

Fig. 54. - IIead and Foot of Greater Tattler. Natural size.

migrations. A few are also observed to linger through the summer, but we have no evidence that the bird ever breeds with us. It is seen chiefly in May and Septem- 
ber, though also frequently. in August, both coastwise and in the interior, in the autumn usually in small flocks, with other birds of the bay and marsh. It is commonly called the "winter yellow-legs," by the gunners, to distinguish it from the smaller species next to be noticed, to which the same description is applied. It is remarkable for its shrill, piercing cries, reiterated whilst the bird is flying. These notes are readily imitated, and the yellow-legs may consequently be easily decoyed within the deadly range of the concealed sportsman, or the less harmful purview of the nervous tyro.

\section{LESSER TATTLER; LESSER YELLOW-LEGS.}

Totanus flavipes $(G m$.) Vieill.

Chars. A miniature of the preceding; colors the same; legs comparatively longer; bill grooved rather more extensively, perfectly straight. Length under 12.00, usually to.00-11.00; extent about 20.00 ; wing under 7.00 ; tail under 3.00 ; bill always under 2.00 ; tarsus about 2.00 .

This species occurs with the preceding in autumn, but it is not a regular spring migrant, and is quite scarce with us during the vernal season. We are aware that the New England local lists, which generally speak of this bird in the same terms as those used in noting the preceding species, do not support this statement; but it is a fact nevertheless. (See Hapgood, Forest and Stream, xvii, Oct. 20, I881, p. 226; and Maynard, B. E. N. A., pp. 393, 394.) The bird is common, and wellknown to the gunners, who sometimes call it the "summer yellow-legs," to distinguish it from the pre- 
ceding, as odd birds may be found with us throughout that season. Its cries resemble those of the other, but are clearer and not so loud.

The Yellowshank, so far as known, nests only in high latitudes. The eggs are deposited on the ground, in a little depression, lined with a few dried leaves or grasses. They are three or four in number, narrowly and pointedly pyriform, measuring from $\mathrm{I} .58 \times 1.18$ to $\mathrm{I} .78$ $\times$ I. I 5 ; the longest not being always also the broadest. The ground is a clear clay-color, sometimes tending more to buffy or creamy, sometimes rather to light brown. The marking is bold and heavy, but presents the customary great diversity, some eggs being very heavily splashed with blotches confluent about the larger end, while others have smaller clean-edged spots all over the surface. The markings are rich umberbrown, often tending to chocolate, sometimes almost blackish. The paler shell-markings are usually numerous and noticeable. An occasional "albino" egg is seen, whitish, with scarcely any markings. All the many eggs examined are from Arctic America.

\section{SOLITARY TATTLER; AMERICAN GREEN SANDPIPER.}

Rhyacophilus solitariUs (Wils.) $B p$.

Chars. Bill moderately longer than head, very slender, straight, grooved a little beyond the middle; bill and legs both darkcolored; only a very rudimentary web between inner and middle toe. Above, dark lustrous olive-brown, streaked on the head and neck, elsewhere finely speckled, with white. Below, white, the jugulum and sides of neck shaded with brownish and streaked with dusky; sides, axillars, lining of wings, and tail- 
feathers beautifully and regularly barred with white and black. Bill blackish; legs dark greenish, drying quite black. Length, 8.00-9.00 ; extent, 1 5.50-17.00 ; wing, 4.75-5.40; tail, 2.25 ; bill, I.12-1.24; tarsus, I.20-1.30.

The New England status of this bird is not determined with desirable precision. We think it is really to be classed as a summer resident, and a breeder within our limits, in the Canadian Fauna at least, though the

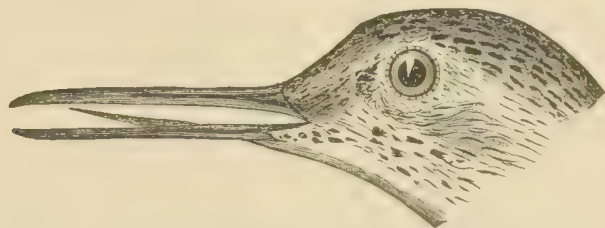

Fig. 55. - Head of Solitary Sandpiper. Nat. size.

evidence favoring this view is not entirely satisfactory. It is not one of the "high north" birds; our Arctic explorers do not report it from such regions, and it unquestionably passes the summer in portions of the United States adjoining British provinces, though its breeding has thus far eluded satisfactory observation, and the eggs are still a special desideratum. In Southern New England it is chiefly if not entirely a migrant.

Mr. E. A. Samuels speaks of its remaining about Canton, Mass, during the summer, and thinks that it breeds there. Mr. Maynard prints a note from $\mathrm{Mr}$. Brewster, to the effect that Solitary Sandpipers were common at Gorham in July, when they were migrating, and that he saw a pair with young at Franconia in August (Pr. Bost. Soc., xiv, I871, p. 383). Dr. Brewer marks the species as a summer resident in Northern New England (Pr. Bost. Soc., xvii, I S75, p. 446). The 
latter author also furnishes the most conclusive evidence we have that the bird actually breeds in New England. He heard of one having been shot by Mr. Jenness Richardson, about the middle of May, I878, in Castleton, Vt., near a nest from which one egg was obtained. The nest was a mere depression in the ground, in a pasture bordering a swamp ; the bird was discovered on it. "This egg resembles no egg in my possession, and in its appearance there is something suggestive of an egg prematurely cut from the parent. It is smaller than I anticipated, measuring only $\mathrm{I} .37 \times 0.95$, while the egg of Totanus ochropus, which bird closely corresponds in size and appearance with our Solitary, measures I.5O $\times$ I. IO. The ground color is a light drab, similar to that of Egialites melodus. Over this are scattered small, rounded markings of brown, some of these quite dark, nowhere confluent, and never large enough to be called blotches. At the larger end are a few faint purplish or lilac discolorations or shellmarkings. In shape it is an elongated pyriform." (Bull. Nutt. Club, iii, I878, p. 197.)

The Solitary Sandpiper ordinarily appears in New England by the end of April or early in May, and remains until October - exceptionally until November, as in the case recorded by Maynard, as above cited. It is not a bird of the shore or open marsh, but of pools and ditches, ponds under cover, and other retired wet places. Though a timid bird, like most of its tribe, it is under ordinary circumstances familiar and unsuspicious, often permitting a close approach before taking flight. 


\section{SPOTTED SANDPIPER.}

\section{Tringoïdes macularius (L.) Gray.}

Chars Bill straight, only about as long as head or tarsus, grooved for about $\frac{3}{4}$ its length. Tarsus about as long as middle toe and claw ; tail rounded, half as long as the wing. Bill and feet palecolored. Above, silky ashy-olive (color of a cuckoo) with a coppery lustre, finely varied with blackish. Line over eye and entire under parts, pure white, fully spotted with dusky - the spots larger and more crowded on the female than on the male, wanting in the young. Secondaries and their coverts broadly tipped with white; tail incompletely white-barred. Feet pinkishwhite, drying yellowish ; bill flesh-color, black-tipped. Length, about 7.50 ; extent, 13.50 ; wing, 4.00 ; bill, tarsus, and middle toe with claw, each, $0.95^{-1}$.00.

This is one of the very few Waders, if indeed not the only one, which apparently nests with equal readiness in

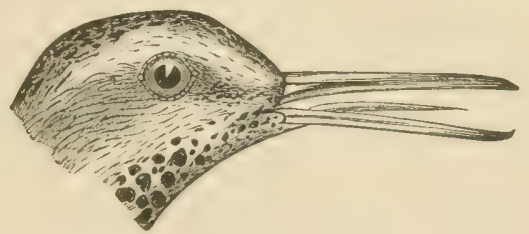

Fig. 56. - Head of Spotted Sandpiper. Nat. size.

almost any portion of its North American range. Hence it is a summer resident in New England, where it arrives the latter part of April or beginning of May, and remains until October, being diffused in abundance all over our country wherever there is water. It is a familiar inhabitant of moist meadow-land and the brookside, where its low, devious flight, its amusing posturing, and its mellow "peet-weet" are known to all who 
have any senses for the feathered life of our fields. Like the bowing and nodding of the Solitary Sandpipers, are the still more curious actions of the Spotted Sandpipers, thus described by Coues: "a queer balancing of the body upon the legs, constituting an amusement of which these last-named birds are extremely fond. As often as the Tip-up, or 'Teeter-tail,' as it is also called, stops in its pursuit of insects, the fore part of the body is lowered a little, the head drawn in, the legs slightly bent, whilst the hinder parts and tail are alternately hoisted with a peculiar jerk, and drawn down again, with the regularity of clock-work. The movement is more conspicuous in the upward than in the downward part of the performance; as if the tail were spring-hinged, in constant danger of flying up, and needing constant presence of mind to keep it down. It is amusing to see an old male in the breeding season busy with this operation. Upon some rock jutting out of the water he stands, swelling with amorous pride and selfsufficiency, puffing out his plumage till he looks twice as big as natural, facing about on his narrow pedestal, and bowing with his hinder parts to all points of the compass. A sensitive and fastidious person might see something derisive, if not actually insulting, in this, and feel as Crusoe may be presumed to have felt when the savages who attacked his ship in canoes showed the signs of contumacious scorn that De Foe records. But it would not be worth while to feel offended, since this is only the entirely original and peculiar way the Tip-up has of conducting his courtships. Ornithologists are not agreed upon the useful purpose subserved in this way, and have as yet failed to account for the extraordinary performance." 
The nest is made in a field, pasture or meadow, often at a considerable distance from any water. It is usually a mere depression in the ground, lined with a few blades of grass, but sometimes a good deal of a nest is constructed of hay and moss, particularly in the North. The eggs are usually four in number, pointedly pyriform in shape, of a clay color or pale creamy-brown, heavily blotched with blackish-brown and neutral tint, measuring about $1.30 \times 1.00$, but very variable in size and in the precise pattern of the markings.

\section{THE RUFF OR REEVE.}

\section{Machetes pugnax (Limn.) Cur.}

Chars. Bill straight, about as long as head, longer than tarsus, gape reaching back of base of culmen; outer and middle toe webbed, inner cleft; tarsus longer than middle toe and claw. Tail about half as long as wings, barred. In the breeding season, face of male beset with yellow warts, and neck ornamented with a frill of extravagant feathers, endlessly varied in colors; female lacking these ornaments. Above, varied with black, brown, buff and chestnut ; sides of the rump white ; under parts white ; quills dusky, with white shafts; wing-coverts ashy-brown ; bill blackish, flesh-colored at base; legs dingy yellow. Length about I2.00; wing, 7.00 ; tail, 300 ; bill, I.50; tarsus, 2.00. Female smaller.

This is a widely distributed old world bird, occasionally straggling to America, there being various instances of its capture in this country, and especially in New England. One of the earliest of these records is given by Mr. G. N. Lawrence (Ann. Lyc. Nat. Hist., N. Y., v, I 852, p. 220) : a specimen from Long Island, apparently the same as that alluded to by Cassin, in Baird's B. of N. A., I858, p. 727. Mr. G. A. Boardman's catalogue of 
birds found about Calais, Me., speaks of the Ruff as accidentally occurring in that vicinity in one or two instances (Pr. Bost. Soc., ix, I862, p. 129). On the strength of these cases, Coues appears to have included the species in his New England List of I868, with the remark: "Accidental from Europe ; several instances of its capture on the New England coast " (Pr. Essex Inst., v, I 868, p. 296).

Dr. Brewer, however, speaks as if Mr. Boardman's captures were not actually made within Maine limits, and would open the New England record with the unquestionable case recorded by Mr. Brewster in Am. Nat., vi, 1872 , p. 306 ; that of a specimen taken on the Newburyport marshes, May 20, 187r. This was a female, with the ovaries so active that it was judged she would soon have laid. The same gentleman also gives the second definite New England record: a female, killed at Upton, Oxford Co., Maine, Sept. 8, I 874 (Bull. Nutt. Club, i, I876, p. 19). Mr. Gordon Plummer has a young male specimen, shot by a Mr. Churchill at Chatham, Mass., Sept. II, I880, as recorded in Forest and Stream of Oct. 7, I8So, p. I 86 - said to be the second for Massachusetts, the third for New England, and the ninth for North America.

It may be further mentioned here that the Ruff has even been taken in Ohio - Nov. I0, I872, at the Licking Reservoir, thirty miles east of Columbus, by Theodore Jasper (see Wheaton, Bull. Nutt. Club, ii, I877, p. 83). 


\section{BARTRAMIAN SANDPIPER; UPLAND PLOVER.}

\section{Bartramia longicauda (Bechst.) Coues.}

Chars. Bill shorter than head, about equal to middle toe and claw, straight; culmen a little concave, upper mandible grooved for three-fourths its length, gape wide and deep, reaching below eyes. Tail more than half as long as wing, graduated. Tibia denuded for nearly the length of the middle toe. Tarsi much longer than middle toe, scutellate before and behind. Adult: Alove blackish, intimately varied with white or tawny edges of the feathers, the dark color prevailing on the crown and back, the light on the head, neck, and wings ; on the scapulars and long inner secondaries, the black resolved in regular angular bars on a greenish-brown field. Rump and most upper tail-coverts brownish-black, a few of the longer coverts barred to correspond with the tail. Tail-feathers mostly orange-brown, with numerous dark bars and spots and one broad black subterminal band, and white tips. Under parts dull soiled whitish, or tawny-white, the jugulum streaked with blackish, the sides with sharp, black arrow-heads; axillars and lining of wings white, barred with black. Bill yellow, with black ridge and tip ; feet clay-colored, drying darker; iris dark-brown. Length, I1.75-12.75; extent; 22.09 ; wing, 6.25-7.00; tail about 3.50 ; tarsus, 1.75 ; bill, 1.001.25; middle toe and claw the same.

An elegant species, commonly resident in New England during the summer, and especially abundant in spring and fall. It arrives about the Ist of May, and may be found until October, chiefly in upland fields and meadows; being one of those waders that appears to be quite independent of the vicinity of water, and well deserving its name of "upland " plover. It is of course not a "plover" at all, but a Sandpiper; its erroneous appellation coming probably from the shortness of its 
bill, and some of its habits, in some respects not unlike those of a Charadrius or Squatarola. It is a favorite game bird, and great numbers are annually killed for the table.

"The nest," says Coues, " is flimsy - merely a few straws to keep the eggs from the ground, in a slight depression. The eggs are ordinarily four in number, as usual among Waders. The numerous specimens I have collected are somewhat notably constant in characters, both of size and coloration. In dimensions they range from $1.90 \times 1.30$ inches, to $1.70 \times 1.25$, averaging about $1.75 \times 1.28$. The ground is pale claycolor, or a very light drab-sometimes the palest possible creamy-brown - with scarcely a shade of olivaceous. They are spotted all over, but much more thickly at the larger end, with rather small, sharp, surface markings of umber-brown, overlaying a smaller number of purplish-gray shell-markings. However thickly they may be sprinkled, the spots are rarely, if ever, confluent into masses of any size, the largest I have seen not exceeding the diameter of a pea. These larger blotches are irregular in contour, but the smaller ones are mostly rounded."

\section{BUFF-BREASTED SANDPIPER.}

\section{Tryngites rufescens (Vicill.) Cab.}

Chars. Bill shorter than head, very slender and acute, grooved nearly its whole length, as in a Tringa, but gape extensive, and end of bill not dilated or sensitive. Tarsus longer than middle toe and claw; toes cleft to the base, or with only the most rudimentary basal webbing. Primaries peculiarly marbled in 
color - ashy-brown, blackening at end, extreme tip white, most of the inner webs of the primaries, and both webs of the secondaries pearly-white, speckled, clouded and marbled with black. Upper parts brownish-black with a greenish-gloss, each feather edged with tawny or yellowish-brown, giving the prevailing tone. Under parts buff or fawn-colored, unmarked excepting a few blackish specks on the breast. Central tail-feathers greenishbrown, blackening at the end, the others paler, often rufescent, with white or tawny tips and black subterminal bar; also, usually some black marbling or streaking. Length, 7.50-8.25: extent about 16.00 ; wing, 5.10 ; tail, 1.50 ; bill along culmen $0.67-0.75$; along gape, I.00; tarsus, 1.20; middle toe and claw, I.00.

A curious little Sandpiper, of general distribution in North America, apparently nowhere very common. It is a spring and autumn migrant only in New England, quite rare in the spring, less so in the fall. It is easily recognized by its special form, and the curious mottling of the wing-feathers, the

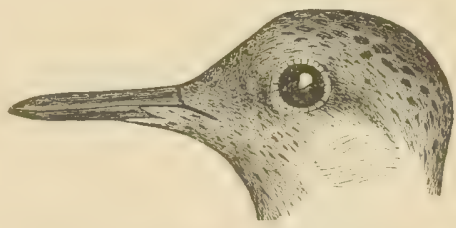

Fig. 57. - HEAD OF BUFF-BREASTED SANDPIPER. pattern of which is best displayed from the under side. It appears to be most nearly related to the Bartramian, with the habits of which its own to some extent correspond.

"Of the very rare and scarcely known eggs of the Buff-breasted Sandpiper," says Coues, "I have examined about a dozen sets in the Smithsonian, all collected by Mr. MacFarlane in the Anderson River region and along the Arctic coast to the eastward. They are very pointedly pyriform. The following measurements indicate the size, shape, and limits of variation: $\mathrm{I} .5 \mathrm{O} \times \mathrm{I} .03$; $1.48 \times$ I.IO; $1.45 \times 1.02 ; 1.40 \times 1.04$. The ground is 
clay, sometimes with a slight olivaceous or drab shade, oftener with a clear grayish cast, of rather peculiar shade. The markings are extremely bold and sharp, though not heavier than usual. Taking a specimen in which the markings are most distinct, we find heavy blotches and spots of indeterminate size and shape all over the egg, of rich umber-brown, deeper or lighter according to the quantity of pigment. Nearest these blotched varieties come the splashed ones, in which the markings mass more heavily about the larger end, and are elsewhere spattered over in rather small markings. This is the more frequent pattern; and in some cases the splashing hides the ground-color at the large end. Other examples are spotted with rather narrow markings that seem to radiate from the large end, becoming largest and thickest around the greatest diameter of the egg, and being much smaller elsewhere. All the eggs have the usual neutral or stone-gray shell-markings, and in most of them there are at the large end a few spots or scrawls of hlackish over all the other markings. According to the labels, the nidification is not peculiar, the nest being a slight depression in the ground, lined with a few dried grasses or leaves. The eggs are four in a majority of instances."

\section{LONG-BILLED CURLEW; SICKLE-BILL.}

\section{Numenius longirostris Wils.}

Chars. Birds of this genus are distinguished by the length, slenderness and downward curvature of the bill. In these respects the present species stands first, the bill measuring from 4.00 to 8.00 
in length, lisually 5.00 or 6.00. Length, 24.00 or more ; extent about 37.00; wing, 10.00-12.00; tail, 4.00; tarsus, 2.75-3.50. Prevailing tone of plumage rufous, usually deepest under the wings, where little varied with other color; primaries dark, varied with rufous. Top of head variegated with rufous or whitish and blackisl, without distinct pale median and lateral lines. Upper parts brownish-black, speckled with tawny or cinnamon-bruwn; tail-feathers and secondaries cinnamon-brown, with pretty regular dark bars throughout. U'nder parts rufous or cinnamon of varying intensity, usually deepening to chestnut under the wings, fading to whitish on the throat; the jugrulum and fore breast with dusky streaks which tend to become bars or arrow-lheads on the sides. No white on rump, wings, or tail. Bill black, much of under mandible pale flesh-color or yellowish ; feet dark.

This great Curlew, the largest of the whole family Scolopacida, is rated by Dr. Brewer as a rare midsummer visitor along the coast (Pr. Bost. Soc., xvii, I875, p. 446). As Mr. Purclie has shown, however (Bull. Nutt. Club, i, I876, p. 73 ; ii, I877, p. I7) it is rather to be placed in the category of the spring and autumn migrants, as given by Allen, Merriam, and Boardman,

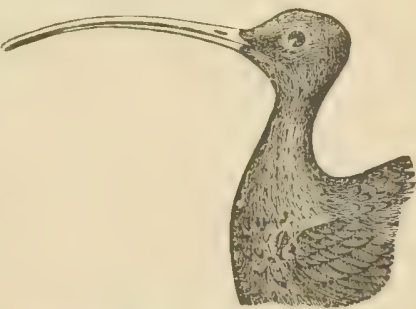

Fiv. 5S.-HEAD OF LUNG-BILLED CLRLEW. though a few individuals undoubtedly spend the summer on the more unfrequented portions of the coast and in the adjoining marshes. Unlike others of its genus, it is not a bird of the high north. It is generally seen in small flocks, and found to be extremely wary and difficult to approach. It is not one of our common birds, nor at all regular in its times of appearance and disappear. ance. 
The eggs of the Long-billed Curlew are not often so pyriform as those of the smaller waders, being in shape not unlike a hen's eggs. Different specimens measure : $2.45 \times 1.85 ; 2.60 \times 1.80 ; 2.65 \times 1.80 ; 2.70 \times 1.90 ;$ $2.80 \times$ I.90. They are clay-colored, with more or less olivaceous in some instances, and in others a decidedly buffy shade. The spotting is generally pretty uniformly distributed and of small pattern, though in many cases there is larger blotching and even massing about the great end. The color of the markings is sepia or umber, of different shades in the buffy-tinged specimens, rather tending to chocolate. The shell-markings are commonly numerous and evident.

\section{HUDSONIAN CURLEW; AMERICAN WHIMBREL.}

\section{Numenius hudonicus Lath.}

Chars. With a general resemblance to the foregoing, this species is readily distinguished by smaller size, shorter and less curved bill, and less rufescent plumage. Length, 16.00-18.00; wing, 9.00-10.00; tail, 3.50; tarsus, 2.25-2.50; bill, 3.00-4.00. General tone of coloration scarcely rufous, the under parts, and the variegation of the upper, being whitish or ochraceous. Top of head uniform blackish-brown, with well-defined median and lateral pale stripes. Upper parts brownish-black, speckled with whitish, ochraceous or pale cinnamon-brown, in same pattern as in longirostris, but the dark in excess of the light colors, and these never strongly rufescent. Tail ashy-brown (not rufous), with numerous narrow blackish bars. Primaries fuscous, marbled or broken-barred with pale color. Lining of wings and axillars rufescent, spotted or barred throughout with dusky. Under parts soiled whitish or somewhat ochraceous, only decidedly rufescent on crissum if anywhere; the jugulum and 
fore breast with dusky streaks which, as in other species, change to arrow-heads or incomplete bars on sides of breast and body. Bill blackish, some part of lower mandible pale.

A migratory species, occurring along the coast under the same circumstances as the last, but more frequently observed. Still it cannot be considered a common bird, and it appears to be irregular, occurring at times in numbers, and again being seldom seen. Of its belonging to the category of migrants there is no question; still it has been repeatedly found in summer. Dr. Merriam notices (Rev. B. Conn., p. I66) the occurrence of many individuals near Milford, Conn,, in July; of others (p. rog) during the same month at South Hampton, Long Island; and others again near Saybrook, Conn., late in August. Probably, however, it does not breed in New England.

The egrs resemble those of $N$. borcalis rather than $N$. longirostris, being in fact difficult to distinguish from those of the former. Coues gives the measurements as from 2 . I 2 to 2.30 in length, by about I.60 in breadth.

\section{ESKIMO CURLEW ; DOUGH-BIRD.}

\section{Numenius borealis (Forst.) Lath.}

Chars. Of smallest size in the genus, with shortest, slenderest and least curved bill. Length, 12.00-15.00: wing under 9.00; tail, 3.00 ; tarsus, 2.00 or less; bill, 2.00 or more, perhaps nearer 3.00 . General tone of plumage little rufescent, the under parts, and the variegation of the upper parts, rather ochraceous than rufous. Top of head variegated throughout, without median light line, but with well-defined pale superciliary line. Upper parts brownish-black, varied with ochraceous or very pale cinnamon- 
brown, the dark being in excess of the light color, and the general effect as in hudsonicus. Tail barred much as in that species. Primaries and most of the secondaries plain fuscous, entirely lacking the variegation seen in the foregoing species of the genus. Under parts ochraceous or somewhat rufescent, very variable in tone, sometimes quite whitish ; marked as in the other species with dusky arrow-heads, streaks, and bars, but these more numerous, frequently occupying all the under parts excepting the chin and middle of belly. Axillars and lining of wings rufescent, barred throughout with dusky. Bill black, with base of lower mandible pale or yellowish.

As Dr. Coues remarks, it is singular that this species should not be common in New England, considering the almost incredible numbers that take their departure for the south from Labrador in early autumn: but such, however, is the case. The birds probably take flight from points further east, the majority proceeding directly on their way without visiting our shores. It is more numerous, however, in fall than in spring, at which latter season it is comparatively seldom observed. It may be seen sometimes so late as the middle of October, and is on the whole the most numerous of the three species of the genus.

This species breeds in great numbers in the Anderson River region, usually making up its nest-complement of four eggs by the third week in June. The nest is generally in an open plain, and is a mere depression in the ground, lined with a few dried leaves or grasses. The eggs vary to the great extent usually witnessed among Waders. The ground is olive-drab, tending either to green, gray, or brown in different instances. The markings, always large, numerous and bold, are of different depths of dark chocolate, bistre, and sepia brown, with the ordinary stone-gray shell spots. They 
always tend to aggregate at the larger end, or, at least, are more numerous on the major half of the egg; though in a few instances the distribution is nearly uniform. Occasionally the large end of the egg is almost completely occupied by confluence of very dark markings. Eggs vary from 1.90 $\times 1.40$ to $2.12 \times 1.33$, averaging about $2.00 \times 1.45$. 


\section{FAMILY IBIDID $Æ$ : IBISES.}

\section{GLOSSY IBIS.}

\section{Plegadis falcinellus (Limn.) Kaup.}

Chars. Bill very long and slender, compressed-cylindric, curved downward, deeply grooved nearly or quite to the obtuse tip (thus closely resembling the bill of a Curlew). Nostrils linear, in advance of base of upper mandible. Frontal feathers sweeping with convex outline across forehead near but not quite at base of bill ; lores broadly naked, the bare space embracing the eyes; a pointed projection of feathers on side of lower mandible ; another median one advancing acutely on bare space of the chin. Tibix bare for a distance equal to one half or more of the length of tarsus, which latter is longer than the middle toe and claw; mostly reticulate, but scutellate in front. Lateral toes unequal, the inner shortest; claws all long and slightly curved; inner edge of middle claw dilated and jagged, but not regularly combed as in a Heron. Coloration dark glossy green and chestnut or mahogany color. Length about 24.00 ; extent about 36.00; wing, 10.00-I1.00; tail, 4.00; bill, 4.50-5.50; tibiæ bare 2.50 ; tarsus, 3.50 .

Leaving now the Limicoline or plover-snipe group, with the last of the large family Scolopacida, we enter upon quite a different order of birds, - that of the Herodiones, or Herons and their allies, among which are the Ibises, constituting a family apart from Ardei$d a$, or the Herons proper. Two species of Ibis have occurred in New England - the Glossy and the White Ibis; both, however, are rare and casual visitors.

In the case of this remarkable visitor to our country 
we wish to trace the entire record. The Glossy Ibis belongs more properly to the old world than to any part of America, and it nowhere appears to be as abundant in the United States as is its congener, Plegadis guarama, in the West. The notices of occurrences in New England date at least as far back as the time of Nuttall, who says that "a specimen has occasionally been exposed for sale in the market of Boston" (Man. Orn., ii, I 834, p. 89 ), as also cited by Peabody, Rep. B. Mass., I 839 , p. 365. But this does not necessarily imply that such birds were actually killed in Massachusetts, though warranting the probability that this was actually the case. The Rev. J. H. Linsley speaks of five specimens taken at Stratford, Conn. (Am. Journ. Sci., xliv, 1843, p. 266; cited by Merriam, Rev. B. Conn., I877, p. I IO). Mr. Samuel Cabot, Jr., records a specimen from Fresh Pond, * Cambridge, Mass, two from Middleboro, Mass., and one from Middletown, Conn., all in "June, I 850 " (Pr. Bost. Soc., iii, I850, pp. 3I3, 3I4). This record is cited by Putnam, 1856, Allen, I864, Coues, I 868, and Maynard, I870; and Mr. Purdie receives from F. C. Browne, of Framingham, extracts from a journal kept while he was at Harvard College in IS5o. His classmate shot the Fresh Pond bird, with which were two others that got away. This was May 7 th or 8 th, I 850 - not June, as Mr. Cabot has it. Under date of May 23, I850, Mr. Browne's journal reads: "Mr. Thoreau tells me of a Glossy Ibis shot near the Concord river by a Mr. Melvin." This Concord river specimen, then, is one which has not

* Mr. Purdie informs Dr. Coues that this I850 Fresh Pond specimen is still preserved in the rooms of the Boston Society of Natural History. 
hitherto been publicly recorded. "May 25th: Calling at Ogden's (the taxidermist's) he told me he had mounted two more Ibises (since my first one) which came from Middleboro." Thus we have four birds taken, and two others seen, in Eastern Massachusetts, in May, 1850. The Middletown, Connecticut, bird was probably also shot during the same month (May, I850), and is very likely the same one that Dr. Merriam speaks of in 1877 as in the Museum of the Wesleyan University, "taken about I 855 " by Dr. Barratt (Cabot says Dr. J. Barrett).

Thus there must have been a special irruption of Glossy Ibises in Southern New England in May, I850, - doubtless many more than we have heard of. No further record appears for twenty years, until Allen adduces a specimen from Nantucket, Sept., I 869, and one from New Hampshire, October, i 858 (Am. Nat., iii, I870, p. 637). The New Hampshire instance is presumably the same as that cited by Maynard (Nat. Guide, I870, p I45) - Stafford Ridge, N. H., and by Dr. Charles Palmer (Am. Nat., v, I872, p. I20), who says the bird was shot at Alton, N. H.

In 1878 , Dr. Brewer, alluding to previous captures, as above, adds the record of a specimen purchased in Boston market, which had been shot at Orleans, May 5, 1878 (Bull. Nutt. Club, iii, I878, p. I5 I).

The same number of the Bulletin, next page (p. I52) gives a note, from Mr. Charles B. Cory, of his examination of a fresh specimen taken on Cape Cod, May 4, I878. A note from Mr. Allen, upon information furnished by Mr. R. Deane, states that this specimen was shot at Eastham, Mass., by Mr. Augustus Denton, and adds: "Mr. N. Vickary, of Lynn, Mass., writes me 
that he has in his possession also a specimen of this species taken at East Orleans, May 5, 1878. This, with the specimens above recorded by Dr. Brewer and Mr. Cory, makes three that were taken at nearly the same date and near the same locality on Cape Cod, during the first week in May, the present year" (Bull. Nutt. Club, iii, I 878 , p. I 52 ).

Referring to this visit of May, I878, quite like that which occurred in May, I 850 , Dr. Brewer says: "Mr. Frank L. Tileston informs me that in the following August [of I 878], several specimens of what were called "black curlews" were noticed on Prince Edward's Island; one of them was shot by a gentleman of Boston, but was not preserved" (Pr. Bost. Soc., xx, 1879, p. 272).

\section{WHITE, IBIS.}

\section{Eudocimus albus (Limn.) Wagl.}

Chars. General characters of Plegadis, but face more denuded, the whole chin being bare in the adult ; claws stout, obtuse, curved. Plumage not metallic; entirely white in the adult, with several outer primaries glossy black at the ends. Bare parts of head, and most of bill, with the legs, orange, red, or carmine; bill dusky at end; iris blue. Young brownish with whitish rumpand under parts and gray tail. Length, about 26.00; wing, I1.50I2.50; tail, 5.00 ; bill, $5.00-7.00$; tarsus, 3.50 ; middle toe and claw, 2.50 .

This is an abundant bird of the South Atlantic and Gulf States, rarely straying even to the Middle Districts. Two specimens are noted as having been taken on Long Island (Giraud's B. L. I., I 844, p. 275). There is but a single authentic New England case of the kind - that 
of a specimen seen and thoroughly identified, though not secured, by Mr. Geo. Bird Grinnell, near Milford, Conn., May 23, I875. The details of the case are given in Am. Nat., ix, 1875 , p. 470, and again in Merriam's Rev. B. Conn., 1877 , p. I IO, as follows: "Late in the afternoon of May 23 [1875], I observed near Milford, Conn., a specimen of the Ibis alba. I recognized the bird as it flew over me, and following it to a small pond where it went down, discovered it perched upon a tree over the water. I carefully examined it with a good glass, at a distance of about one hundred and fifty yards, and by this means was enabled to note every detail of form and color. It was in full plumage, the white being pure, and the naked skin about the head bright red. After watching it a few moments I tried to approach it, but before I came within gunshot it flew, uttering a hoarse cackle as it went off." 


\section{FAMILY ARDEIDÆ: HERONS.}

\section{GREAT BLUE HERON.}

\section{Ardea herodias Linn.}

Chars. Of very large size, and dark varied colors; never white. Back without peculiar plumes, but scapulars lengthened and lanceolate; an occipital crest, two long filamentous feathers of which are deciduous, ornamenting the bird only during the breeding season. Bill yellow, more or less blackened on the culmen; iris yellow; lores blue; legs and feet blackish, soles yellowish. Tibiæ and edge of wing chestnut. Forehead and middle of crown white; sides of head, and the crest, black. Neck pale purplish-gray, with a mixed black, white, and rusty throat-line, yielding to white on chin and cheeks. General color of upper parts slaty-blue; tail the same; scapular feathers more pearly-gray; wing-feathers deepening from this color to black on the primaries. Young with colors less pronounced, etc. ; but the species may always be recognized by its dark color and large stature. Length, 42.00-50.00; extent about 70.00 ; wing, I8.00-20.00; tail, 7.00-8.00; bill, 4.50-6.25, usually between 5.00 and 6.00 ; tibiæ bare $3.00-4.00$; tarsus usually $6.50-7.00$.

This great Heron, commonly but wrongly known as the "blue crane," is a summer resident in New England; more abundant during the migrations, and generally but unevenly distributed over the country, according to the nature of the surface. It usually arrives early in April, and departs in October, some individuals, however, lingering into November. It is to be seen in its usual resorts singly or in small flocks, and 
breeds in communities, the nest being placed in trees in swampy localities, built chiefly of large sticks. The eggs, commonly three or four in number, but often more, are elliptical in shape, pale bluish-green in color, and measure about $2.60 \times 1.75$. It is a wild and wary bird, very difficult to approach under ordinary circumstances.

\section{GREAT WHITE HERON, OR EGRET.}

\section{Herodias egretta $(G m$. $) G r$.}

Chars. Of large size; color entirely white at all ages and seasons; no crest, but back with a magnificent train of fastigiate feathers in the breeding season, reaching beyond the tail ; neck closely feathered. Bill, lores and eyes yellow; legs and feet black. Length, 36.00-42.00 ; extent about 55.00 ; wing, I6.00-17.00 ; tail, 5.50-6.50; bill, 4.50-5.00; tarsus about 6.00; tibiæ bare 3.50.

This very elegant bird, conspicuous by reason of its stature and color, is of rare and probably not regular occurrence so far north as New England. The earlier records, made at a time when precision in the identification of rare occurrences was considered of less consequence than it is now rightly held to be, are too indefinite to be satisfactory now. Thus Prof. Emmons in his catalogue of Massachusetts birds (I835) speaks of the Great White Egret as a regular visitant, and a breeder. The Rev. W. B. O. Peabody also notices the bird (B. Mass., I839, p. 363), on authority of Audubon per Brewer. These are probably the sources of Mr. F. W. Putnam's remark, that the bird occurs in Essex County, Mass, as a very rare spring visitor (Pr. Essex Inst., i, I 856, p. 2 I 8). 
Later and definite records are the following for Massachusetts: One at Springfield, prior to I864, and one at West Brookfield, in I860; Allen, Pr. Essex Inst., iv, I 864, p. 76. Two taken at Hudson, by Mr. S. Jillson, and others seen, in I867; one at Ashland, Mr. A. L. Babcock, May, several years before; one near Lynn, Mr. N. Vickary; Allen, Am. Nat., iii, 1870, p. 637. (See also Maynard, Nat. Guide, I870, p. I 43.)

Mr. Purdie records a specimen from Westford, Mass., Am. Nat., vii, I873, p. 693 ; and the same gentleman informs us of a MS. note he has of a bird shot at Plymouth, Mass., Apr. I8, i 875.

For Maine we have one record, given by Mr. N. C. Brown, in Rod and Gun, vi, I875, p. SI ; Scarboro', April, I875.

The Connecticut record has been given by Dr. Merriam in the following terms (Rev. B. Conn., I877, p. I I I):- "A rare visitor from the South. Several specimens have been taken in Massachusetts, and I have myself seen it at the 'Ox Bow' in Connecticut. A specimen was shot near Middletown, Conn., some years ago, and is now in the Museum of the Wesleyan University. Mr. Grinnell has seen it on the marshes near Milford, Conn., in September. Dr. Wood tells me that, several years ago, one spent a week on a marsh near East Windsor Hill, Conn. Mr. Fred. Sumner Smith tells me that he saw a pair of these birds at Lake Saltonstall (near New Haven), Conn, during the latter part of July, r876, and two weeks later, at the same place, saw no less than seven individuals feeding together. They were exceedingly shy and he could not approach within gunshot." 
Mr. R. Deane notes a Grand Menan case, - bird shot Aug., I 879 (Bull. Nutt. Club, I880, p. 63).

Notwithstanding these summer occurrences, the natural breeding of the Egret in New England remains to be attested.

As to occurrences of this Egret beyond us, may be here noted the specimen examined by Mr. C. J. Maynard, shot at Grand Menan, New Brunswick, Novcmber 3, I878, as recorded by Mr. Ruthven Deane (Bull. Nutt. Club, iv, I879, p. 63), who also notices in the same place a Nova Scotian instance given by Mr. I. Matthew Jones of Halifax (Trans. Nova Scotia Inst. Nat. Sci., ii, I868, p. 72).

\section{SMALL WHITE HERON, OR EGRET.}

\section{Garzetta candidissima (Gm.) $B p$.}

Chars. Like the last in being entirely white at all seasons and ages, but much smaller. An occipital crest, a recurved dorsal train, and lengthened feathers of the lower neck, in the breeding season. Lores, eyes and toes yellow ; bill and legs black, former yellow at base, latter yellow at lower part behind. Length about 24.00; extent, 36.00-40.00; wing, 9.50-11.00; tail, 4.00; bill, 3.00 or more; tarsus, 3.75 ; tibiæ bare 2.50 .

This is another of New England's rarities, occurring under nearly the same conditions as the Great White Egret, though more seldom. There are early Massachusetts records, as in the other case, but all of them "shaky," as is probably also Mr. Putnam's notice of 1856. In 1864, Allen adduces an instance of the occurrence of the bird near Boston, in I862, and says for Massachusetts that "stragglers have been taken in a few 
instances " (Pr. Essex Inst., iv, I 864, p. 86. See also Maynard, Nat. Guide, I870, p. I43). For Connecticut, Dr. Merriam says in general terms "a rare accidental visitor from the south;" refers to Stratford, Conn., on the authority of Linsley, and adds that "Dr. Crary says he has taken it near Hartford, Conn.," but gives no specific case (Rev. B. Conn., i877, p. I I I).

Mr. Purdie contributes an interesting note of the occurrence of the Little White Egret in Nantucket, Mass., at an unexpected time of the year-in March, I 882 (Bull. Nutt. Club, vii, I882, p. 25 I).

The species is given as having occurred in Nova Scotia, by Jones (Trans. N. S. Inst. Nat. Sci. ii. I 868 p. 72).

Its capture on Long Island, Aug. 4, I88I, at Great South Bay, is recorded by Louis A. Zerega (Bull. Nutt. Club, vi, I88I, p. 248).

\section{LITTLE BLUE HERON.}

Florida cerulea (Limn.) $B d$.

Chars. Dichromatic; i. e, either white or colored. In the colored phase, dark grayish-blue, becoming purplish or marooncolored on the neck and head. Loral space and bill blue, latter blackening toward the end ; eyes yellow. The white birds are liable to be confounded with Garzetta candidissima; notıce lores and basal half of bill greenish-blue, the rest blackish; most of lower mandible yellowish; legs greenish-blue, with yellow traces, or bluish-black. Size of the little White Egret.

A rare and casual visitor from the South, like the last species. The name appears in nearly or quite all the New England lists, as far back at least as the time of Linsley, who took the bird at Stratford, Conn. Mr. 
E. A. Samuels notes a definite case from Barnstable, spring of I86 I (Orn. and Oöl. N. E., I867, App.). Mr. Allen has noted its occurrence in Massachusetts. There are several late authentic Connecticut records. According to Merriam, "Mr. Dayan saw a small Heron on Lake Whitney, in April, 1877, which he supposes to have been this species. In the cabinet of Mr. Coe, of Portland, Conn., is a beautiful specimen of this species which he shot in that vicinity early in July, I875. . . There were two of them together, but the other escaped. Mr. Erwin I. Shores, of Suffield, Conn., writes me that one was shot there about the middle of May by Mr. Chas. Newton" (Rev. B. Conn., I877, p. I I I).

Dr. Brewer records that the Boston Society of Natural History has an example of this species, in immature plumage, shot at Cohasset, about 1869 , by Mr. Henry D. Morse (Pr. Bost. Soc., xx, I879, p. 272).

The species has recently been added to the Avifauna of Maine, by Mr. N. C. Brown, who notes a specimen captured on the Scarborough Marsh in Sept., ISS I, by Mr. Winslow Pilsbury (Bull. Nutt. Club, vii, I882, p. I 23).

\section{GREEN HERON.}

Butorides virescens (Limn.) Cab.

Chars. Of smallest size in the family (excepting the Least Bittern). Adult in breeding season with the crown and occipital crest and lengthened narrow feathers of back glossy green, sometimes with a bronzy iridescence, the dorsal plumes in high plumage with a glaucous bluish cast. Wing-coverts green, with tawny edgings; neck purplish-chestnut, the throat line varied with dusky and white. Under parts mostly dark brownish-ash ; belly variegated 
with white. Quills and tail-feathers greenish-dusky, with a glaucous bloom; edge of wing white, and usually some of the quills white-tipped. Lores and iris yellow; bill greenish-black, much of the under mandible yellow; legs greenish-yellow. Length, 16.00-18.00; extent about 25.00 ; wing, 6.50-7.50; bill, 2.50 ; tarsus, 2.00 ; middle toe and claw about the same; tibiæ bare $\mathrm{I} .00$ or less.

A common summer resident, arriving during the middle or latter part of April, and remaining until or into October. It is generally distributed in suitable places, - those which are watery enough to yield proper food, and sufficiently well-wooded to afford the privacy and shelter which Herons require. The nest is constructed in May; it is a rude platform of loosely arrayed twigs, placed upon some bush or wide spreading tree not far from the water. The usual altitude is 10 to 30 feet from the ground; an apple-tree is sometimes selected. The eggs, usually five or six in number, are pale greenish-blue, like those of other Herons, rather elliptical than ovoiclal in shape, measuring about $\mathrm{I} .50 \times$ 1.18. A correspondent and friendly critic, who helps me to revise these proofs, remarks, that this biography is "as thin as the bird itself." But it is absolutely necessary to economize space, and I generally prefer to be brief in the cases of the best-known birds.

\section{NIGHT HERON; QUA-BIRD; SQUAWK.}

Nyctiardea grisea navia (Bodd.) Allen.

Chars Of medium size, with short legs and very stout bill, about as long as tarsus or middle toe and claw. No peculiar plumes, except two or three extremely long slender feathers springing in a 
bundle from the hind head. Crown, scapulars and interscapulars dark glossy-green; other upper parts bluish-gray with a lilac or lavender shade, most decided on the neck. Forehead and throat-line white, as are the long occipital plumes. Under parts whitish, tinged with lilac. Eyes red; lores greenish; bill black; legs yellow. Length about 24.00 ; extent about 44.00 ; wing, $12.00-14.00$; tail, 5.00 ; bill, tarsus, and middle toe with claw, each, 3.00. Young very different, being grayish-brown above, the feathers paler edged, conspicuously spotted with white; the lower parts paler or dull whitish, streaky with darker color; quills chocolate-brown, white-tipped; no crest.

This is another common summer resident of New England, on the whole our best known representative of the family Ardcide - not only on account of the numbers which pass the season with us, but of their general distribution throughout our country in suitable places, and their colonization by hundreds or even thousands to breed in extensive heronries. At such places, hundreds of nests may be seen, sometimes several in the same tree, - even so many as ten or a dozen; - the trees seeming as if whitewashed with the incessant droppings, and the vegetation beneath them being entirely killed by such excessive manuring. Numerous colonies have been discovered and explored by enthusiastic ornithologists, particularly in southern New England. Tall trees are usually selected for the nesting sites, and access to the nests is not always easy. They are bulky platforms of twigs, visible at long distances on the boughs of the trees, which are whitened and more or less bared by their numerous untidy tenants. The eggs are usually four to six in number; but their variability in this respect, and the fact that the same nest may contain fresh and incubated eggs and hatched young together, makes it probable that the birds carry their 
communism to the extent of using each other's nests in some cases. The eggs resemble those of other Herons in shape and color, and they measure on an average $2.10 \times 1.45$; but they are quite variable in dimensions.

Though properly a summer resident, the Night Heron is occasionally found with us all the year round. According to the "Oölogist," (v, I 880, p. 84) individuals have been seen on Shelter Island, Conn., in January and February, I870, and January 28, 188 I ; as well as in February, I880, at Norwich, Conn. (ibid., p. 78). Mr. C. J. Maynard, in giving a good account of this species, speaks of its occurrence all winter in Massachusetts (Birds Eastern N. Am., I88 I, p. 4I8).

\section{YELLOW-CROWNED NIGHT HERON.}

\section{Nycterodius violaceus (Limn.) Reich.}

Chars. Bill extremely stout, shorter than tarsus; culmen and gonys both much curved; tarsus longer than middle toe and claw, reticulate excepting above in front. Occiput in the breeding season with a dependent crest. General color light grayishblue, darker on back, where the feathers have black centres and pale edges, and paler on under parts. Head and upper neck behind, with cheek patches, the crown, and most of the crest, white, more or less tinged with buff. Bill black; eyes orange; lores greenish; bill and feet black and yellow. Length about 24.00 ; extent, 44.00 ; wing, 12.00 ; tail, 5.00 ; bill scarcely 3.00 , over 0.50 deep at base ; tibiæ bare 2.00 ; tarsus, 4.00 ; middle toe and claw, 275. Young quite different, but readily known by the stout bill and other characters.

A rare and casual visitor from the South. We have information of only two instances in which the bird 
has thus far been found in New England. One of these is that recorded by Mr. Allen, Lynn, Mass. October, 1862 (Amer. Nat., iii, I870, p. 637). This is believed to be the first authentic New England record. The second case known to us is that of a young bird taken at Somerville, Mass., July 30, 1878, as recorded by Mr. Brewster (Bull. Nutt. Club, iv, 1879, p. I24), and by Dr. Brewer (Pr. Bost. Soc., xx, 1879, p. 272). Mr. Brewster's interesting note is transcribed in full, with our usual generosity toward those who are unwise or unfortunate enough not to take the Nuttall Bulletin - a work which, by the way, gives more important information respecting the bircs of North America than any other equal number of pages of print which have appeared in this country since 1876 : "On the afternoon of July 30 , 1878, Mr. George Cunningham - who resides in a rather densely populated part of Somerville, just beyond the line separating that city from Cambridge, was attracted by a commotion among the Robins and other small birds in the orchard behind the house. Upon investigating the cause of this unusual excitement, a large bird was seen to take flight and disappear over an adjoining fence. Shortly after this there was another alarm from the orchard, and it was found that the strange intruder had returned. A neighbor, who is fond of shooting, was called in, the bird winged, and after a sharp chase overtaken. It showed plenty of fight, and, to use the words of its captor, 'chattered very like a monkey.' . . The specimen is in the spotted immature plumage, and is apparently very young, inasmuch as many of its feathers still retain the peculiar hair-like filaments which characterize the downy stage of Herons, and which are pushed outward on the tip of the 
feathers that succeed. This fact, taken in connection with the date of capture, is certainly suggestive of a not very remote breeding-place, though the bird was perhaps old enough to have flown northward from the Carolinas, its nearest known breeding-ground." Young Herons, we may add, have a way of wandering aimlessly about during the latter part of summer, before they are old enough to have sense enough not to go where there are Nuttall Bulletinians about.

\section{AMERICAN BITTERN.}

\section{Botaurus mugitans (Bartr.) Coues.}

Chars. Tail of only ten feathers (twelve in all the foregoing Herons). Size medium. Bill shorter than tarsus, which is shorter than middle toe and claw, and broadly scutellate in front. No peculiar plumes. General plumage of the upper parts singularly freckled with brown, black, tawny, and whitish; neck and under parts ochrey or tawny whitish, each feather marked with a brown dark-edged stripe, the throat-line white, with brown streaks; a patch of velvety black on each side of neck above. Iris yellow; bill on edge blackish, the rest pale yellowish; legs yellowish-green. Length, 23.00-34.00! extent, 32.00-45.00! wing, 9.50-1 3.00 ; bill about 3.00 ; tarsus about 350 ; middle toe about the same.

A common summer resident, usually arriving during the middle or latter part of April, and remaining until November. Being one of the hardiest as well as one of the most erratic of the family Ardcida, the Bittern is doubtless to be sometimes seen in New England in winter, though we have not laid hands upon any positive record to that effect. It is a bird of the bog and reedy 
marsh rather than of such woody swamps as most Herons affect, and differs from any of the foregoing in nesting upon the ground, as well as in the character of its egrs. Mr. Endicott remarks very pointedly upon the general uncertainty that pervades ornithological writings respecting the color of the Bittern's eggs, "finding the enumerated authorities determined that the eggs should have green on them of some shade or other." He calls them "a dark drab;" Mr. Samuels says "a rich drab, with sometimes an olive tinge."

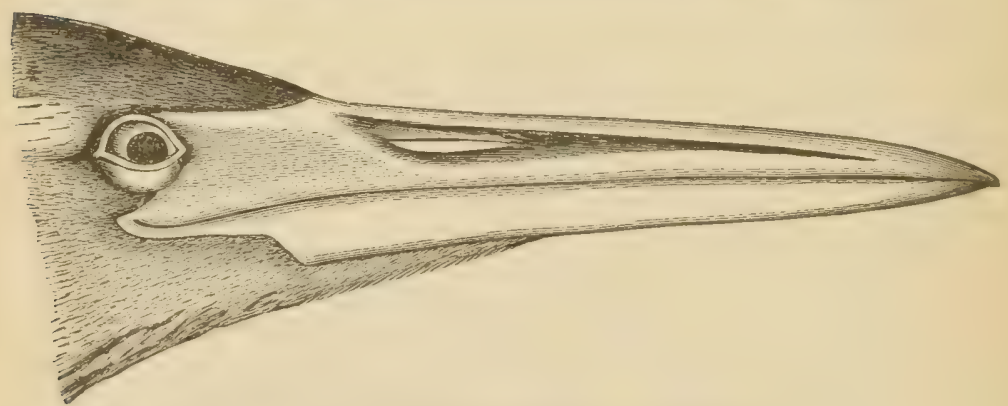

Fig. 57- - Bill of Botaurus musitans. Natural size.

The color of the several sets before me may be called a brownish-drab, with a shade of gray. It is a difficult color to name, and doubtless varies in tint in different specimens; but it is probably never anything like the clear, pale greenish of the eggs of ordinary Herons. Specimens measure $1.90 \times 1.50$, to $2.00 \times 1.50$; the nest-complement is three to five.

The Bittern also differs from most Herons in being "wild, shy, and solitary." We oftener start one from his lonely vigils in the bog, than find several, or even a pair together, excepting in the breeding season. No doubt he enjoys life after his own fashion, but his notions 
of happiness are peculiar. He prefers solitude, and leads the eccentric life of a recluse, "forgetting the world, and by the world forgot." To see him at his ordinary occupation, one might fancy him shouldering some heavy responsibility, oppressed with a secret, or laboring in the solution of a problem of vital consequence. He stands motionless, with his head drawn in upon his shoulders, and half-closed eyes, in profound

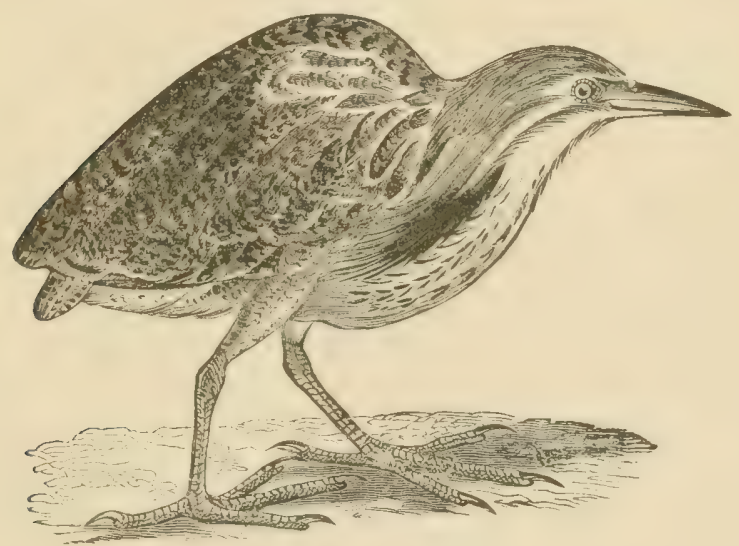

Fig. 5S. - Bittern.

meditation, or steps about in a devious way, with an absent-minded air; for greater seclusion, he will even hide in a thick brush-clump for hours together. Startled in his retreat whilst his thinking-cap is on, he seems dazed, like one suddenly aroused from a deep sleep; but as soon as he collects his wits, remembering unpleasantly that the outside world exists, he shows common sense enough to beat a hasty retreat from a scene of altogether too much action for him. Some such traits have doubtless led to the belief that he is chiefly 
a nocturnal bird; but such is not the case. He may migrate by night, but so does the Killdeer, and the Bobolink, and many other birds not in the least nocturnal. Nor is the Bittern either lazy or stupid, as some may suppose. He is simply what we call a shady character - one of those non-committal creatures whom we may invest, if we please, with various attributes, and perhaps consider very deep, without sufficient reason; the fact being, that we make the mystery about him. There is nothing remarkable in the fact that he prefers his own company, and dislikes to be bored. He lives in the bog, where he finds plenty to eat that he likes best, and is satisfied to be simply let alone.

When the Bittern is disturbed at his meditation, he gives a vigorous spring, croaks at the moment in a manner highly expressive of his disgust, and flies off as fast as he can, though in rather a loose, lumbering way. For some distance he flaps heavily with dangling legs and outstretched neck; but when settled on his course he proceeds more smoothly, with regular measured wingbeats, the head drawn in closely and the legs stretched straight out behind together, like a rudder. He is very easily shot on the wing - easily hit, and dropping at a touch even of fine shot. When winged, he croaks painfully as he drops, and no sooner does he touch the ground than he gathers himself in defensive attitude to resent aggression as best he can. He fights well, and with more spirit and determination than he might be expected to show - like many other quiet, inoffensive creatures when quite sure they have a grievance and are pushed to desperation. He has a very ugly way of pointing his resistance with quick thrusts of his spear-like bill, capable of inflicting no slight wound on an incautious 
hand. But it avails little; a kick from a cowhide boot, or a thump with the butt of a gun, generally decides the unequal contest.

The food of this bird consists of various kinds of small aquatic animals. In its stomach may be found different molluscs, crawfish, frogs, lizards, small snakes and fishes, as well as insects. Such prey is captured with great address, by spearing, as the bird walks or wades stealthily along, the thrust of the bill being marvellously quick and skilful.

\section{LEAST BITTERN.}

\section{Ardetta exilis (Gm.) $G r$.}

Chars. Smallest of the whole family ; in form, nearly like the common Bittern, having also only io tail-feathers. Adult male: Crown, back and tail glossy greenish-black; neck behind, most of the wing-coverts, and outer edges of inner quills, chestnut; other wing-coverts brownish-yellow, like the front and the sides of the neck and inner parts generally; the throat-line varied with white, and sides of the breast with a brownish-black patch. Female with the black of the back entirely, that of the crown mostly, replaced by purplish-chestnut; edges of the scapulars forming a brownish-white stripe on each side. Bill mostly pale yellow, culmen blackish; lores light green; eyes and toes yellow; legs green, the hinder scales yellow. Length about I2.50; extent about I 8.00 ; wing, $4.00-5.00$; tail, bill, tarsus, middle toe and claw, each, $2.00 \mathrm{cr}$ less.

This queer little Heron, which looks as if might have been a cross between a Bittern and a Rail, is a regular though not abundant summer resident in southern New England. It is hardly a bird of the Canadian Fauna, belonging rather to the Carolinian, and also being not 
rare in the Alleghanian. The older New England lists usually present it as a rare bird, and so it is ordinarily taken to be; but, however the case may formerly have been, the bird is certainly no rarity now in the Alleghanian Fauna. Prof. Verrill's list notes its presence in Southern Maine (Pr. Essex Inst., iii, I862, p. I 57), and it has lately been traced to New Brunswick (Chamberlain, Bull. Nutt. Club, vii, I882, p. I05), five individuals having been taken between the spring of 1877 and the fall of 1880 on the Bay of Fundy shore, about ten miles east of St. John. (See Orn. and Oöl, vii, I882, p. I Io.)

The manner of the bird's presence in Connecticut has been carefully noted by Dr. Merriam, who says that "the Least Bittern seems to be at present a pretty regular summer resident, though formerly regarded as an accidental visitor. Linsley gave it from Northford, Conn., without comment. It has certainly bred here for several years past, and on June 27, I876, $\mathrm{Mr}$. Nichols found its nest at Bradford, Conn., containing one fresh egg. Have seen it in September. They were particularly abundant throughout the State during the season of I875. Mr. W. IV. Coe, who has seven beautiful specimens in his cabinet, showed me five eggs which he took from a nest at Portland, Conn., June I4, I873, and says that they breed regularly in that vicinity. Mr. Geo. Bird Grinnell also tells me that he takes two or three every year (generally in August or September). They follow up the Connecticut Valley to Massachusetts." (Rev. B. Conn., I 877 , p. I I 3.)

The Least Bittern has even been found with us in winter. Mr. Jencks adduces such an instance, one having been known in Rhode Island, Feb. 28, I88 I (Orn. and Oöl., vi, Is8I, p. 6). 
Its breeding in Connecticut and Rhode Island is noted in the same periodical, vi, $188 \mathrm{I}, \mathrm{p} .8$, and v, 1880 , p. 78. According to Mr. Samuels it has been found to breed in all the New England States (Orn. and Oöl. of N. E., I 867 , p. 403). But we think the bird must be scarce north of Massachusetts. Coues gives the eggs as "three to five" in number; the full set appears to be five. They are white with a faint bluish tint, elliptical or equalended in shape, and measure from 1.20 to 1.25 in length by 0.90 to 0.95 in breadth, being thus not dissimilar to Pigeons' eggos in general aspect. Several sets have been taken in Massachusetts.

Mr. Brewster has noted the curious fact that upon examining the stomach of a Least Bittern shot at Belmont, Mass., May I I, I876, he found that organ fairly crammed with white, clean cotton wool, the greater portion of which had been swallowed in one lump, though there were several smaller flakes, and among these some slender white worms - notwithstanding all which, the bird seemed to be in good health and spirits (Bull. Nutt. Club, i, I876, p. 76). 


\section{FAMILY GRUID $Æ$ : CRANES.}

\section{$\rightarrow \infty$ \\ GREAT WHITE, OR WHOOPING CRANE.}

Grus americana (L.) Timm.

Chars. Of great stature, and the adult with the plumge pure white, with black primaries, primary coverts and alula; bill dusky greenish ; legs black ; bald part of head red, the sparse hair-like feathers black. Length about 50.00 ; extent, 90.00 ; wing, 24.00; tail, 9.00 ; tarsus, 12.00 ; middle toe, 5.00 ; bill, 6.00 .

Cranes are birds of great size, standing especially high on the legs. The general build is something like that of Herons, with which they are generally associated in the popular mind; but they belong to a different order, Alcctorides, their true relationships being with the Rails, Gallinules and Coots, not with the Herons, Ibises and Storks.

There are three North American species, two of which have been found in New England.

In his interesting article on the "Decrease of Birds in Massachusetts" (Bull. Nutt. Club, i, I 876, pp. 53, 58), New England's greatest ornithologist, Allen, speaks of the Brown or Sandhill Crane, and perhaps the White or Whooping Crane, as having formerly inhabited Massachusetts, though extirpated at so early a date that they had not been previously recognized as belonging to the fauna of that State.

"In all the early notices of the natural productions of New England, the Crane is mentioned among the few birds usually enumerated. Emmons [1833] gives the 
Whooping Crane (Grus americana) in his list of the birds of Massachusetts, but subsequent authors have generally believed without due authority, and of late it has been wholly lost sight of as a bird of the State. That some species of Crane, and in all probability both species, was common in New England in early times is beyond question. Both the Sandhill and the Whooping Cranes have still a wide range in the interior, passing northward in summer far beyond New England. Neither species has of late been met with north of New Jersey, where the Whooping Crane occurs only as a rare casual visitor. Morton wrote, of 'Cranes, there are greate store, that ever more came there at S. Davids day, and not before; that day they would never misse. These doe sometimes eate our corne, and do pay for their presumption well enough; and serveth there in powther, with turnips to supply the place of powthered beefe, and is a goodly bird in a dishe, and no discommodity.' * This shows that the Crane, and not a Heron, is the bird to which reference is made."

In I 842, Zadock Thompson still speaks of the Whooping Crane as "occasionally seen during its migrations" in Vermont (Hist. Vermont, 1842, p. 103).

\section{BROWN, OR SAND-HILL CRANE.}

\section{GRUS PRATENSIS Bartr.}

Chars. Smaller than the last, and in adult plumage plumbeous-gray, never whitening; primaries, their coverts, and the alula, ashy-

- New English Canaan. Printed by Charles Greene, 1632. Reprinted in Force's Historical Tracts, vol. ii, tract 5, pp. 47, 48. 
brown, little darker than the general plumage ; shafts of primaries white. Wing about 22.00; tail, 9.00; tarsus, 9.50-10.00; bill along culmen 5.00-6.00; middle toe 3.50-4.00.

Our remarks upon the preceeding species have anticipated some points in the New England history of the present one. We have to note further that in 1792 , Jeremy Belknap gives the Sandhill Crane as a bird of New Hampshire (Hist. N. H., iii, I 792, p. r69); and that Samuel Williams, about the same time, states that the species was one of the commonest of the "water fowl " of Vermont (Hist. Vt., I 794, p. II9).

No modern instance of this species or the preceding appearing in New England is known to us. 
RALLUS LONGIROSTRIS CREPITANS : CLAPPER RAIL. 279

\section{FAM. RALLID $Æ ;$ RAILS AND THEIR ALLIES.}

\section{CLAPPER RAIL, OR SALT-WATER MARSH- HEN.}

\section{Rallus longirostris crepitans (Gm.) Ridg.}

Chars. Bill longer than head, slender, decurved, with long nasal groove extending beyond its middle. Nostrils linear, sub-basal. Hind toe not one half as long as tarsus. Above, variegated with dark olive-brown and pale olive-ash, the latter edging the feathers. Below, pale dull ochrey-brown, whitening on the throat, frequently ashy shaded on the breast; the flanks, axillars and crissum fuscous-gray, with sharp narrow white bars. Quills and tail plain dark brown, without chestnut on the coverts ; eyelids and short superciliary line whitish. The general tone is that of a gray bird, as compared with the reddish-brown cast of R. elegans. Length, 14.00-16.00; extent about 20.00 ; wing, $5.00-$ 6.00 ; tail, $2.00-2.50$; bill, $2.00-2.50$; tarsus, $1.67-2.00$; middle toe and claw, 2.00-2.33.

The New England range of this bird is not determined with absolute precision. The species is probably to be regarded as a straggler in most of New England, and as a locally distributed summer visitor all along the coasts of Massachusetts, Rhode Island, and Connecticut. To dispose first of the earlier records, we may note that Linsley took the bird at Stratford, Conn., where he states it "breeds abundantly" (Am. Journ. Sci., xliv, 1843, p. 267). The species is also given as of New England, in more or less general terms, by Putnam, Pr. Essex Inst., i, 1856, p. 229 ; Allen, Pr. Essex Inst., iv, I864, p. 87 ; Samuels, Orn. N. E., I867, p. 47 I ; Coues, 
Pr. Essex Inst., v, I868, p. 296 ; Maynard, Nat. Guide, I 870 , p. I45. These writers all credit the species to Massachusetts, probably resting upon the authority of Cabot, Pr. Bost. Soc., iii, 1850, p. 326. Dr. Brewer has, however, corrected an error in this case, the individual referred to by Cabot having really come from Long Island, N. Y. (Pr. Bost. Soc., xvii, I 875, p. 447). Mr. Maynard, however, states positively that a specimen had some years previously been taken in Ipswich by Mr. J. F. LeBaron.

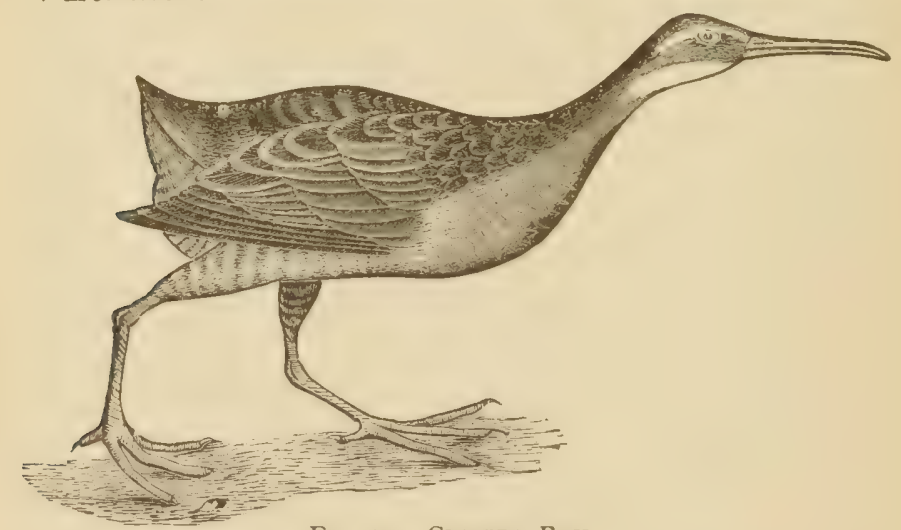

Fig. 59. - Clapper Rail.

Recurring once more to the old Connecticut record left by Linsley, we may next note Dr. Brewer's statement that the Clapper Rail "breeds in S. W. Conn., in salt marshes on shores of L. I. Sound. Not found in any other portion of New England." (Pr. Bost. Soc., xvii, 1875 , p. 447.) This statement, however, was soon negatived by $\mathrm{Mr}$. Purdie, who adduced an instance of the occurrence of the species in Massachusetts, this being probably the first authentic record for that state. Purdie's specimen was taken in Boston Harbor, May 4, 
I 875, having flown on board a vessel (Bull. Nutt Club, ii, 1877, p. 22). This same case is noted by Merriam (Rev. B. Conn., I 877 , p. I I 5) ; by Allen (Bull. Essex Inst., $\mathrm{x}, \mathrm{I} 878, \mathrm{p} .25$ ) ; and by Brewer (Pr. Bost. Soc., xix, I878, p. 307), who, however, misprints the date as “May, 1876." The specimen is preserved in the Boston Natural History Society. The second Massachusetts case is furnished by Mr. Brewster, who notes the capture of a Clapper Rail at Plymouth, Mass., late in October, I 879 ; it was killed on a salt marsh where another large Rail supposed to be of the same species was also seen (Bull. Nutt. Club, vi, I88 I, p. 62).

We also have authentic advices of the Clapper Rail in Maine, where, according to Mr. N. C. Brown, it appears to be an occasional visitor. "Mr. Samuel Hanson, a gentleman who is perfectly familiar with the species, has given me three instances of its occurrence in the vicinity of Portland. One specimen was killed by himself, in Falmouth, on the I 7 th of October, I866, and about the same time two others were noticed in the game-bag of a sportsman of the town. A probable fourth specimen (if correctly identified, doubtless the first killed in the state) was shot by my friend Mr. Luther Redlow, about September, I 864."* (Bull. Nutt. Club, iv, I879, p. I08.)

* Mr. Brown further states: "A contributor writing from Portsmouth to the defunct 'Country' [a newspaper of New York] under date of February I4, I878, noted the capture of a Rallus crepitans at York, Me., in the last week of December, I875. Since the gentleman chose to conceal his identity under the initial ' $E$,' I am unable to say under whose sponsorship this record was made, but regard it as probably correct. Mr. Purdie writes me that his allusion on page 22 , vol. ii, of this Bulletin, to the bird's occurrence in Maine was based on a knowledge of the same specimen, which, he adds, was preserved by Mr. Vickary, of Lynn, Mass." 


\section{FRESH-WATER MARSH HEN; KING RAIL.}

\section{Rallus elegans $A u d$.}

Chars. With a general resemblance to $R$. crepitans, but much more brightly colored, as well as larger. Adult, above distinctly streaked with brownish-black and tawny-olive, becoming rich chestnut on the wing-coverts. Below, cinnamon-red, brightest on the breast, fading on the throat and belly; a line of the same over the eye, and dusky stripe through eye; lower eyelid white. Flanks and lining of wings blackish, broadly and distinctly barred with white. Length, 17.00-19.00; extent, 23.00-25.00; wing, $6.00-7.00$; bill, 2.10-2.50; tarsus, 2.30 .

The King Rail is certainly a rare bird in New England, and the manner of its occurrence has not been ascertained with precision. It should probably be classed as a summer visitor of irregular or casual occurrence and local distribution. Its record is quite brief. Linsley gives a single instance of its breeding at Stratford, Conn. (Am. Journ. Sci., xliv, i 843, p. 267). Coues records a Connecticut specimen in the Museum of the Essex Institute, Salem, from West Haven (Pr. Essex Inst., v, I 868, p. 296); apparently the same as noted by Brewer (Pr. Bost. Soc., xvii, 1875, p. 447). Merriam records two cases for the same State: a specimen taken at Portland, by W. W. Coe, and another at Saybrook, in midwinter (Jan. I 4, I 876), by J. N. Clark (Rev. B. Conn., I 877 , p. I I 5). For Massachusetts, Purdie gives the first record, that of a specimen in the collection of Geo. O. Welch, shot at Nahant, Nov. 2I, I875* (Bull. Nutt.

* This is the specimen noted by Brewer (Pr. Bost. Soc., xix, I 878, p. 307) in "the cabinet of Mr. Willard S. Brewer," "shot at Nahant in the spring of $1876 . "$ (See Brewster, Bull. Nutt. Club, 
Club, ii, I877, p. 22). Another Massachusetts record is also furnished by Mr. Purdie, that of a specimen from Sudbury Meadows, "some years since" (Bull. Nutt. Club, iii, I 878 , p. I46).

The first and only Maine record, to our knowledge, is given by $\mathrm{Mr}$. N. C. Brown, a specimen having been taken by Mr. A. G. Rogers, on Scarborough marsh, Oct. 8, I88 I (Bull. Nutt. Club, vii, I882, p. 60). But in collating the previous New England record Mr. Brown overlooks the West Haven, Conn., case.

\section{VIRGINIA RAIL.}

\section{RALLUS VIRGINIANUS Lim.}

Chars. Coloration exactly as in $R$. elegans, of which species the present is a perfect miniature. Length, 8.50-10.50; extent about I 4.00 ; wing, 4.00 ; tail, I.50; bill, 1.35-1.65; tarsus, 1.25I. 50 .

A common summer resident, though necessarily of local distribution, occurring in those fresh or brackish marshes which afford the conditions requisite for its health and happiness. It arrives the latter part of April or early in May, and usually departs in September. The nest is built in a tuft of reeds or grasses close to the water, and consists of a slight bedding of the same materials. The eggs are six to eight or even more in number, quite like those of the King or Clapper Rail

vi, I88I, p. 62.) Dr. Brewer also overlooks the Linsley record, and the two other Connecticut cases given by Merriam, in stating, as he does in this connection, that "there was no previous record of the bird for New England, except West Haven, Conn." 
in shape and color, but of course much smaller, measuring about $1.25 \times 0.95$. The ground color varies from dull clayey whitish to creamy or pale buff, with numberless reddish-brown markings, irregularly distributed, varying from mere dots to blotches, and mixed with shell spots of paler color. Of about the same size as those of the Sora, they may always be distinguished by their coloration, which is not of the olive or greenish-drab tint displayed by the eggs of $P$. carolina.

Dr. Coues gives the following night-scene in Arizona, with Rail in the foreground (B. N. W., I874, p. 507) :

"A night at Soda Lake, the débouchure of that singular river, the Mojave, was one of the strangest, as well as most uncomfortable, I ever passed. It was late in October, and the full moon threw a pale, uncertain light upon a scene of desolation and of death. On one side stretched the interminable desert of shifting sand, broken here and there by clumps of the foul creosote plant, straggling patches of grease-wood and bitter sage, and scattered, sentinel-like, Spanish bayonet. Along the road just traversed were strewn skeletons of beasts that had fallen in their tracks beneath the scorching rays of the sun. At the foot of some cliffs near by lay whitening the heads and horns of the argali (Oris montana), shot by previous travellers. The bare bones looked of double size and fantastic shape in the uncertain moonlight. Before us lay a dead-white sea of salty efflorescence, where the lake had evaporated or sunk in the sand, leaving its saline matter. It was dry, except toward the middle, where dark green masses of Tulè reeds, contrasting with the snowy whiteness all around, showed that a little water was left. Our animals, like ourselves, were exhausted; one poor creature, cruelly 
over-tasked, had given birth to a foal, and lay groaning by the wayside, unable to rise. The water was too nauseous to drink, and hardly answered to cook with. After a poor meal, we lay down with gloomy thoughts. But sleep was impossible, though wrapped never so closely, head and all, in our blankets. We contended with a bloodthirsty swarm of mosquitoes, wafted like a cloud from the stagnant pools. Every breath of air seemed to vibrate to the continuous hum of the insects; it was open onslaught, as well as stealthy attack, with them, as we huddled around the camp-fire, on the side to which the smoke was wafted, enveloped in blankets, and impatiently waiting the day. We were bitten on every exposed point; for days afterward our hands and faces were sore and swollen, inflamed by the tiny drops of poison instilled into each wound.

"But even under such circumstances I was gratified by the presence of feathered friends. At nightfall some Mallard and Teal settled into the rushes, gabbling curious vespers as they went to rest. A few Marsh Wrens had appeared on the edge of the reeds, queerly balancing themselves on the thread-like leaves, see-sawing to their own quaint music. Then they were hushed, and as darkness settled down, the dull, heavy croaking of the frogs played bass to the shrill falsetto of the insects. Suddenly they too were hushed in turn, frightened, may be, into silence; and from the heart of the bulrushes, "crik-crik-rik-k-k-k," lustily shouted some wide-awake Rail, to be answered by another and another, till the reeds resounded. Then all was silent again till the most courageous frog renewed his pipes. The Rail are, partially at least, nocturnal. During such moonlight nights as this they are on the alert, patrolling the 
marshes through the countless covered ways among the reeds, stopping to cry "all's well" as they pass on, or to answer the challenge of a distant watchman. That they feed by night, as well as by day, cannot be doubted. Their habit of skulking and hiding in the almost inaccessible places they frequent renders them difficult of observation, and they are usually considered rarer than they really are. During the spring migration they seem to pass more swiftly and secretly than in the fall, when, their ranks recruited by the summer's broods, they become more noticeable."

\section{CAROLINA RAIL, OR SORA.}

\section{Porzana carolina (Limn.) Ticill.}

Chars. Rails of this genus differ from the foregoing (Rallus) in having the bill short, straight, and quite stout at base; they are also smaller birds. Above, adult, olive-brown, varied with black, and with numerous sharp white streaks and specks; flanks, axillars and lining of wings barred with white and blackish; belly pale, crissum rufescent; face and central line of throat black, the rest of the throat, line over eye, and the breast, more or less intensely slate-gray, the sides of the breast usually also with some obsolete whitish speckling or barring. Young without these black and slate-colored areas, the throat whitish, the breast brown. Length, 8.00-9.00; extent, 12.00-1 3.00 ; wing, $4.00-4.50$; tail about 2.00 ; bill, $0.67-0.75$; tarsus, I. 33 ; middle toe and claw 1.67.

A very abundant summer resident in suitable localities, being the best known and most equably distributed of the New England Rallida, arriving in April or May and departing usually in September, though some linger into October. The habits are too well-known to require description. 
The eggs of Por ana carolina are spotted just like those of the foregoing Ralli, but are readily distinguished by their strong drab groundcolor, instead of the white or creamy and pale buffy of the former. They are rather smaller than those of $R$. wirginianus, and perhaps more

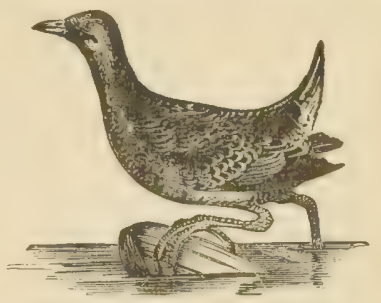

Fig. 60. - Carolina Rail. obtuse, measuring about $1.20 \times 0$.

\section{YELLOW RAIL, OR CRAKE. \\ Porzana noveboracensis ( $G m$.) Cass.}

Chars. Very small. Above, streaked with blackish and brownishyellow, thickly marked also with narrow white semicircles and transwerse bars. Below, pale brownish-yellow, fading on the belly, deepest on breast, where many feathers are darktipped; flanks blackish, with numerous white bars; crissum varied with black, white, and rufous. Length about 6.00 ; wing, 3.25 ; tail, 1.50 ; bill, 0.50 ; tarsus, 0.87 ; middle toe and claw I.I2.

This is represented by the older New England authorities, and by others down to a quite recent date, as a rare species. It is certainly uncommon, as compared with either the Virginian or Carolinian Rail, but there is every reason to believe it is a regular summer resident of New England, and one generally distributed in suitable places. Being insignificant in stature, of no striking colors, and one of the most inveterate skulkers of the reedy recesses, it is very liable to be overlooked. The dates of its appearance and disappearance are 
not ascertained with precision, but probably do not differ materially from those of our other Rails. The bird has been found in October, and even so late as November. Many specimens have been secured of late years during the migrations, in Southern New England. It is also known to breed with us. Nidification is substantially the same as that of other Rails. A set of eggs is described by Coues as consisting of six, differing from those of $P$. carolina in the ground color, which is a rich, warm buffy-brown, marked at the greater end with a cluster of reddish-chocolate dots and spots; the shape as in those of $P$. carolina, but the size smaller, being from I. $15 \times 0.85$ to $1.05 \times 0.80$.

A letter from Mr. Geo. Bird Grinnell to Dr. Merriam, gives a glimpse of the interesting habits of this diminutive Rail : "I was working a young setter on Snipe, on a piece of wet meadow near Milford, Conn., and several times during the early part of the day was annoyed by the pertinacious way in which the dog would trail up some bird which neither he nor I could start. At length, during one of these performances, I saw the puppy grasp at something in the bog before him, and immediately a small Rail rose and fluttered a few yards. Noticing its small size, and the fact that it had some white on its wings, and seeing from its flight that it was a Rail, I shot the bird before it had gone far, and when it was brought by the dog I was delighted to see that it was $P$. noveboracensis, a species I had never before seen alive. During the day several more individuals were secured. The next opportunity I had of looking for these birds was, I think, Oct. 14. That day my brother and I secured eight in an hour or two. They were ridiculously tame, and would run along before the 
dog, creeping into the holes in the bog and hiding there while we tried in vain to start them. I killed one with my dog-whip, caught one alive in my hand, and the dog brought me another, uninjured, which he had caught in his mouth. From what I saw of their habits, I am convinced that the only successful way of collecting these birds is to look for them with a dog. Without one they could never be forced from the ground " (Rev. B. Conn., I 877 , p. I I 8 ).

While it is hardly necessary to follow up the record of this species in New England, I will present the references I have collected: Bailey, Forest and Stream Bird Notes, I882, p. I 24 ; Brewster, Bull. Nutt. Club, vi, I88I, p. I86 ; Maynard, B. E. N. Am., I88I, p. 43I ; Chamberlain, Bull. Nat. Hist. Soc. New Brunswick, 1882, p. 56. Mr. Purdie informs me he has a manuscript record from Mr. G. A. Boardman, of several specimens from the vicinity of Calais, Me.

\section{LITTLE BLACK RAIL, OR CRAKE.}

Porzana Jamaicensis (Gm.) Cass.

Chars. Smallest of all. Upper parts blackish, the hind-neck and fore-back dark chestnut, all finely speckled and barred with white; head and under parts dark slate color, paler or whitening on the throat; the lower belly, flanks, crissum and under wingcoverts barred with white. Quills and tail-feathers with white spots. Length about 5.50 ; wing, 2 75-3.00 ; tail, I.35; tarsus, 0.75 ; bill under 0.50 .

Still another New England rarity from the same ubiquitous but secretive family of the Rails is this dusky 
little Crake, which has only been lately determined to visit us at all. It appears to have been first definitely added to our Fauna by Dr. Brewer, who notes it as a rare summer resident, and cites Hazenville, Conn. (Pr. Bost. Soc., xvii, 1875, p. 447). The next we hear of it is from Mr. Purdie, who adduces another Connecticut instance, and adds a Massachusetts case. "Of this species Mr. Clark, of Saybrook, Conn., writes me that a neighbor of his, while mowing at that place, July I0, 1876 , swung his scythe over a nest of ten eggs on which the bird was sitting, unfortunately cutting off the bird's head and breaking all but four of the eggs (Bull. Nutt. Club, ii, I877, p. 22). These eggs, later inspected by Merriam, are said to agree precisely with Coues' description, " being creamy-white, sprinkled all over with fine dots of rich, bright reddish-brown" (Rev. B. Conn., I877, p. 119). Mr. Purdie also states in the same communication, that he had seen a specimen which was picked up dead on Clark's Island, Plymouth Harbor, Mass., in August, I869. This specimen is the same one mentioned by Mr. Browne in Forest and Stream, viii, I $\$ 77$, p. 33. Another one, to which, however, some doubt is attached, is noted by Mr. Curtis, in the paper last cited, p. I29; see Bailey, Forest and Stream Bird Notes, ISS2, p. 124. Dr. Brewer speaks of the species as "not at all uncommon in Connecticut," but upon what other authority than the records we have here adduced does not appear (Pr. Bost. Soc., xix, I878, p. 307). It is really a bird of South and Central America and the West Indies, the occurrence of which in the United States is in most localities infrequent and irregular. 


\section{FLORIDA GALLINULE.}

\section{Gallinula galeata (Licht.) $B p$.}

Chars. Birds of this genus and the following, as well as Coots, are readily distinguished by the broad, horny plate which ascends from the bill upon the forehead, known as the frontal shield. The bill is much as in the ralline genus Porzana, and the general form is not greatly dissimilar. The present species has the head, neck, and under parts grayish-black, deepest on the head, palest or whitish on the belly ; back brownish-olive; wings and tail dusky ; crissum, edge of wing, outer web of first primary and stripes on the flanks, white. Bill, frontal plate, and ring around tibix, bright red; bill tipped with yellow; tarsi and toes greenish. Length, 12.00-14.00; extent, 20.00-22.00; wing, 6.50-7.50; tail, 3.00 ; gape of bill about 1.50 ; tarsus about 2.00 .

In Southern New England this Gallinule is of regular occurrence, and is considered now by the local authorities to be a rather common summer resident, though it used to be rated as rare or even accidental. The Connecticut cases are numerous, and need not be recapitulated. It is rarer in Massachusetts, where, however, it doubtless breeds (see Allen, Am. Nat., iii, I870, p. 639; Maynard, Nat. Guide, I870, p. I46, and B. E. N. Am., I88r, p. 432.) Mr. Brewster remarks that it probably breeds in the Fresh Pond marshes near Cambridge, where he shot a young bird on the gth of October, I868, and saw another.

Dr. Brewer notes a specimen, now in the Boston Society of Natural History, shot late in the autumn of I872, probably in Octoher, on Hummock Pond, Nantucket (Bull. Nutt. Club, iv, I879, p. 63). The same authority speaks also of a specimen procured in Wayland, by Mr. 
E. O. Bangs, Sept. Io, 1878 (Pr. Bost. Soc., xx, I879, r. 273). Mr. R. Deane notes the Gallinule as probably breeding in New England, in Forest and Stream, xiii, I879, p, 785. Mr. Boardman has taken the Gallinule at Calais, Me. (Am. Nat., v, I87I, p. 662), and Mr. R. E. Robinson records it among the rare Vermont visitors (Forest and Stream, xii, I879, p. 285). Mr. Purdie informs us of various other cases. For New Brunswick, we have the authority of Mr. Brewster for the capture of a specimen at Dick's Lake, in September, I880doubtless the same case as that recorded by Chamberlain, Bull. Nat. Hist. Soc. N. B., I882, p. 56, though the date is there given as September, 1879 . There is also a Nova Scotia record (Gilpin, Orn. and Oöl., vii, I882, p. 123).

\section{PURPLE GALLINULE.}

\section{IONORNis Martinica (Linn.) Reich.}

Chars. Head, neck and under parts beautiful rich blue, with a purplish tinge, blackening on the belly, the sides of the body and lining of the wings bluish-green, the crissum white. Upper parts olive-green, the cerviæ and wing-coverts tinted with blue. Frontal shield blue ; bill carmine, tipped with yellow; legs yellow. Young, with head, neck and lower back brownish ; under parts mostly white, mixed with ochrey; but distinguished in any plumage from the last by the very stout bill with oval nostrils near its middle, obovate frontal shield with a point behind, and toes without lateral margins. About the size of the last.

A very rare and casual visitor from the South; yet there are several authentic instances of the appearance of this "sultan of the water-fowl" in various parts of New England. The earliest of these, to our knowledge, 
that given by the Rev. W. B. O. Peabody, of a specimen from Stoneham, Mass., Nov. 27, I 837 (Rep. B. Mass., I 839, p. 238). Another is furnished by Mr. F. W. Putnam, who notes a capture by Mr. S. Jillson, at Swampscott, Mass., April 22, 1852 (Pr. Essex Inst., i, I856, p. 224; not the same as given by Allen, ibid., iv, I864, p. 87 ; see also Coues, ibid., v, I 868, p. 297). Mr. F. T. Jencks has lately published the record of a specimen taken somewhere about I857, at Westerly, Rhode Island (Bull. Nutt. Club, vii, I882, p. 124). Mr. G. A. Boardman records the bird from Calais, Maine (Am. Nat., iii, 1869, p. 498); and Mr. Purdie gives another Maine case, that of a specimen from Booth Bay, last of September, I 877 (Bull. Nutt. Club, v, I880, p. 242). A still more exceptional apparition of the bird in Halifax, Nova Scotia, Jamary 30, I870, is given by Jones (Am. Nat., iv, 1870, p. 253). Mr. C. P. Whitman notes a specimen taken by Robert Wendell at Rockport, Mass., April I2, I875 (Am. Nat., ix, I875, p. 573). According to Merriam, one was taken about i 855 near Middletown, Conn., and is now in the Museum of the Wesleyan University (Rev B. Conn., I877, p. I 19). For New Brunswick we have two instances, one at Irishtown, Apr. 6, i88 I (Brewster, Bull. Nutt. Club, vi, I87 I, p. I86); the other near Gagetown, on the St. John's river, Sept., I 880 (Chamberlain, Bull. Nutt. Club, vii, I882, p. r05). These are the only cases which have come to our knowledge. 


\section{AMERICAN COOT.}

\section{Fulica americana $G m$.}

Chars. Toes conspicuously lobate with a series of scolloped flaps; a small frontal shield. Dark slate-color, paler or grayish below, blackening on head, tinged with olive on the back; under tailcoverts, whole edge of wing, and tips of secondaries, white. Bill white or flesh-color, marked with reddish-black near end and at base of frontal shield; feet livid greenish ; iris carmine. Length, I4.00-16.00; extent, 23.00-27.00; wing, 7.00-8.00; tail, 2.00 ; bill from gape, $1.25^{-1.50}$; tarsus about 2.00 ; middle toe and claw about 3.00.

This well-known bird is an uncommon summer resident with us, but particularly abundant during the autumnal migration. It is known to breed in New England, though the actual numbers during the season of reproduction are few compared with those which pass through in the spring and fall. It lingers late, and may not improbably be sometimes found in winter.

"The nidification of the Coot," says Coues, " is not the least interesting portion of its history. The mode of nesting is most like that of the Grebes. The nest is said to be sometimes a floating one, moored to the stems of reeds, rising and falling with the tide. One author, in illustration of the insecurity of the bird's home, has related that once during a storm a nest became detached from its moorings by a rise of the water, and drifted about, the parent nevertheless remaining at her post of duty, and safely hatching out her brood during the cruise. This may or may not have been a strict statement of fact. Among many Coots' nests I have found, one was built in a clump of reeds 
where the water was about knee-deep; it was a bulky affair, resting securely on a mass of reedy dibris. The nest itself was built of the same materials, heaped up and little hollowed; it was about fifteen inches in diameter, and half as high. The reed-stems appeared to have been bitten by the bird into short pieces; there was no special lining. This nest was a floating one, in the sense that the platform of broken-down reeds upon which it was built rested on the water; but it was perfectly secure, raised out of the wet, and though loosely constructed, could be lifted up intact. It contained eleven eggs, nearly ready to hatch. They measured from I.75 to 2.00 in length, by 1.20 to 1.35 in breadth, exhibiting the usual variation in contour as well as in absolute size. The shape is much like that of an average hen's egr - perhaps rather more pointed. The ground is clear clay-color, uniformly and minutely dotted all over with innumerable specks of dark brown; a few of the bolder markings are of the size of a pin's head, but the greater number are mere points. But the eggs are not always so uniformly and finely dotted as those of this set were; sometimes the spots being aggregated into blotches of some size, or tending chicfly to wreath around the larger end. Various other nests examined contained an average of ten eggs; some were built just like the one described, while others were on the ground, in comparatively dry spots around the margin of the pools, hidden in rank grass; in all the materials and mode of construction were much the same." (B. N. W., I 874, p. 542.) 


\section{Family ANATID e: SWANS, GeEse AND DUCKS.}

\section{AMERICAN WILD SWAN.}

\section{Cygnus columbianus (Ord) Cones.}

Chars. Tail normally of 20 feathers. Bill black, with a yellow spot between eye and nostril ; the latter at the middle of the bill ; feet black. Plumage of the adult entirely white; of younger birds white, washed with rusty on the head; of youngest, gray or ashy. Length about 4.50 feet.

Note. The Trumpeter Swan, C. buccinator, probably occurs in New England. It may be distinguished by having normally 24 tail-feathers, the bill longer, with the nostrils in its basal half, and no yellow spots. (See Merriam, Rev. B. Conn., 1877, p. I20.)

According to early records it would appear that these beautiful birds were not uncommon in New England; but they are certainly of rare occurrence now. Writing in 1632, Thomas Morton speaks of "greate store at the seasons of the yeare" in the Merrimac River and elsewhere. Linsley speaks of four which were seen, two of them being shot, at Stratford, Conn. Coues, in I 868, calls the Swan a bird "of irregular or at most very rare occurrence in winter" (Pr. Essex Inst., v, I 868, p. 297). Maynard refers to it as having been found at Ipswich (B. E. Mass., I870, p. I46). Dr. Merriam notices two Swans, supposed to be of this species, seen in Branford Harbor, Conn., during a storm, in March, i 876 (Rev. B. Conn., 1877, p. I20). In 1878 (Bull. Essex Inst., x, 
p. 26), Mr. Allen could "point to no recent record of its actual capture" in Massachusetts. The first actual capture recorded of late years is probably that given by Mr. Brewster, who speaks of one taken on Coskata Pond, Buzzard's Bay, Nantucket, March 4, 1878, by Mr. F. P. Chadwick (Bull. Nutt. Club, iii, I878, p. I98). The same excellent authority also notes one supposed and one authentic occurrence, the latter at Seabrook,

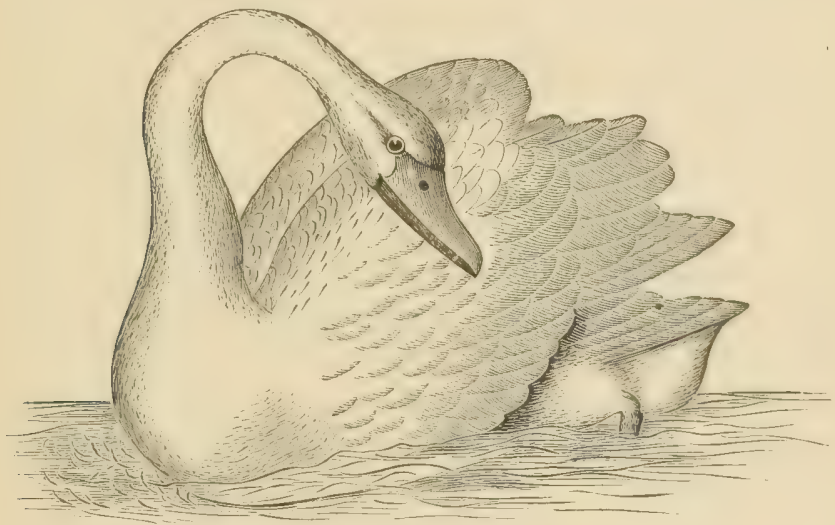

Fig. 61. - American Swan.

N. H., Oct. I 8, I878 (Bull. Nutt. Club, iv, I879, p. I 25). Dr. Brewer speaks of another specimen, in the Boston Natural History Society's collection, which he has no doubt was shot about i 865, at Nahant (Pr. Bost. Soc. Nat. Hist., xx, I S79, p. 274). Mr. Newton Dexter gives a Rhode Island case (Forest and Stream, xiii, I879, p. 848). Mr. Elisha Slade, of Somerset, Mass., saw there a flight of five Swans, Oct. I6, i88o (Bull. Nutt. Club, vi, I88I, p. I23). These comprise all the instances which have come to our knowledge. 


\section{AMERICAN WHITE-FRONTED GOOSE.}

\section{Anser albifrons gambeli (Hartl.) Coues.}

Chars. Bill smooth; the laminæe moderately exposed; tail normally of 16 feathers. Under parts white or gray, extensively blotched with black; back dark gray, with paler or brownish edgings of the feathers; upper tail-coverts white; head and neck grayishbrown, the forehead conspicuously pure white (in the adult; dark in some states); bill pale lake; feet orange, with pale claws. About 27.00 long; wing, 16.00-1 8.00 ; tail, 5.00-6.00; tarsus, 2.75-3.00; middle toe and claw about the same.

A rare spring and fall migrant. The authorities are agreed upon the rarity of this Goose in New England, and some, like Coues, consicier it probably of exceptional occurrence only. We have found no record for Rhode Island, Connecticut, Vermont, or New Hampshire; and our only intimation of the presence of the bird in Maine is afforded by manuscript additions to Mr. Boardman's Catalogue of 1862 , in the possession of Mr. Purdie. As to Massachusetts, Audubon gave the bird in I 839 (Synopsis, p. 272). Allen remarks that some years ago he found specimens in the Boston market supposed to have been taken in Massachusetts (Bull. Essex Inst., x, 1878, p. 26). According to Dr. Brewer, who records a specimen in immature plumage, taken at Gloucester, this Goose was more common thirty or forty years ago than it is now, as appears to be the case with many others of our water-fowl (Bull. Nutt. Club, ii, I877, p. 46). In his list of $\mathrm{I} 875$, Dr. Brewer marks it "rare, migratory" (Pr. Bost. Soc., xvii, I 875, p. 447). 


\section{SNOW GOOSE.}

\section{Cinen hyperboreus (Pall.) Boie.}

Chars. Bill with the teeth very prominent, owing to arching of the edges of the bill ; the enclosed space blackish ; rest of the bill reddish, with white nail; feet reddish, with dark claws. Plumage of the adult white, usually washed on the head with rustyred; the primaries broadly tipped with black. Young ones bluish or leaden-gray on the head and upper parts. Length, about 30.00 ; wing, I 7.00-19.00 ; tail, 5.50-6.50 ; bill, 2.50 ; tarsus, 3.25 .

Note. The Blue Goose, C. ccerulescens, probably occurs in New England, but we have no positive authority for including it. (See Brewer, Pr. Bost. Soc., xvii, 1875, p. 452.) It closely resembles the young of the Snow Goose, and may therefore be easily overlooked.

Though far from being as abundant in Eastern North America as it is in the West, this fine Goose, of swanlike purity of plumage, occurs in New England as a rare regular winter visitor, chiefly along the coast. It arrives late in the fall; many of the migrants pass further south, wintering all along the Atlantic seaboard, while others are to be found with us during the whole season. Early in the spring the birds take flight for the hyperborean regions where they breed. While it is needless to cite all the records we possess, we may refer to the case given by Samuels, of a female shot in Boston Harbor, July, i 860 (Rep. Sec'y Mass. Board Agric., I860, p. 364 ; the date being given as July, i862, on p. 24 of separates of the paper, and as July, I863, in Orn. and Oöl. N. E., p. 482). 


\section{BARNACLE GOOSE.}

\section{Bernicla leucopsis (Bcchst.) Boie.}

Chars. Forehead, cheeks, and under parts of the head white; side of the bill narrowly bordered with black. Crown, nape, and lower part of neck, jugulum, fore part of back, rump, and tail black. Feathers of interscapulars and wings silvery bluishgray, passing into black towards the end, but with the extreme tip whitish-gray. Tail-feathers similarly marked, but without the pale tips. Under parts uniform bluish-white, the feathers on the sides only showing a darker basal portion. Upper tail-coverts and sides of the tail at the base white. Bill and legs black. Length, 28.00 ; wing, 16.50 ; bill, 1.45 ; tarsus, 2.60 .

This is a European Goose, the occurrence of which anywhere in North America is accidental. It is questionable whether it has ever visited New England spontaneously. The early records are too dubious to be relied upon (Quincy, Mass., Cabot, Pr. Bost. Soc., iii, p. I36; Mass. Peabody, Rep., I839, p. 385). As renarked by Dr. Brewer, the supposed occurrences may be traced to the escape of imported birds from confinement: "I omit this from among the birds of New England," he says, "because I am confident that all the instances of its supposed capture have been birds that had escaped from confinement. It is a bird, at best, only accidental in America in a wild state, is not uncommon in private collections of water-fowl, and occasionally escapes. Eight birds escaped from the grounds of a gentleman in Halifax, in the fall of 1871 or 1872 , many of which were afterwards shot at various points along the coast. The specimen taken in North Carolina and referred to by Mr. Lawrence was probably one of these escaped birds" 
(Pr. Bost. Soc., xvii, 1875 , p. 452). But later, the same writer had occasion to restore the bird to his list, as he did in the following terms: "A head and neck of the Barnacle Goose is now in the possession of my young friends, Mr. Russell Hooper and Mr. Outram Bangs, of Boston. These were all that was unplucked of a Goose found in Boston market this winter, and which had been shot at Marshfield, Vt. From the locality, it is not probable that the bird had escaped from confinement, and therefore the species may once more take its place among the many accidental visitors to New England" (Pr. Bost. Soc., xix, 1878, p. 307).

A Barnacle Goose was killed on Long Island, about Oct. 20, I876, by Mr. J. K. Kendall, as recorded by Mr. Lawrence (Bull. Nutt. Club, ii, I877, p. I 8 and note).

\section{BRANT GOOSE.}

\section{Bernicla brenta (Pall.) Steph.}

Chars. Head, neck, body anteriorly, quills and tail, black; a small patch of white streaks on the middle of the neck, and usually white touches on the under eyelid and chin; upper tail-coverts white ; back brownish-gray ; under parts the same, but paler, and fading into white on the lower belly and crissum; black of jugulum well-defined against the color of the breast. Length, 24.00 ; wing, I 3.00 ; tail, 5.00 ; bill, 1.33 ; tarsus, 2.25 .

A spring and fall migrant, and to some extent a winter resident, though not so common at that season as during the migrations, as the greater number of individuals proceed further south. It leaves in April, and does not breed with us. Brant Geese are chiefly 
seen coastwise, being essentially salt-water birds; still they occur inland anywhere, though the fact has been repeatedly denied.

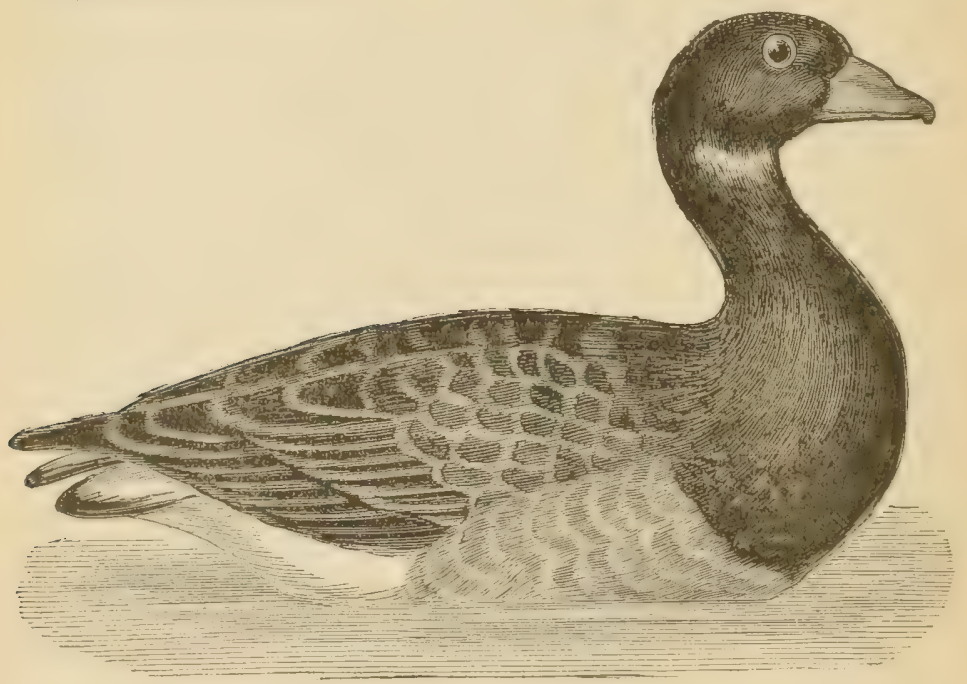

Fig. 62. - Brant Goose.

\section{BLACK BRANT.GOOSE.}

\section{Bernicla brenta nigricans (Lawr) Coues.}

Chars. Similar to the last; black of jugulum extending over most of the under parts, gradually fading behind; white neck patches usually larger and meeting in front.

This variety of Brant is chiefly a bird of Western America, but also occurs along the Atlantic seaboard, and has even been taken in New England. Dr. Brewer gives a case, on the authority of Mr. H. W. Henshaw 
(Pr. Bost. Soc., xvii, I875, p. 447), and Allen connotes the occurrence of Black Brant with the preceding species (Bull. Essex Inst., x, I 87 S, p. 26).

\section{COMMON WILD GOOSE; CANADA GOOSE.}

\section{Bernicla canadensis (L.) Boie.}

Chars. Tail normally is-feathered. Grayish-brown, below paler or whitish-gray, bleaching on the crissum, all the feathers with lighter edges : head and neck black, with a broad white patch on the throat mounting each side of the head; tail black, with white upper coverts. About 36.00 ; wing, 18.00-20.00; ta1l, 6.50-7.50; bill, 1.75-2.00; tarsus usually over 3.00. North America, abundant; United States chiefly in winter, but also in summer; breeding sparingly.

This is the characteristic and only abundant Goose of New England, occurring as a winter resident and spring and fall migrant. It is nearly equally abundant inland and along the seacoast. No regular time of arrival and departure can be assigned, but it is found in spring on the breaking up of the ice, and in fall until its freezing over. The flight begins commonly late in March, and continues through April, and sometimes even in May. In the fall the arrival is generally late in November. This Goose is supposed to breed on some of the islands in Massachusetts and Buzzard's Bay. Mr. Audubon supposed it to breed in New England; but we have no authentic record of its doing so. 


\section{LESSER CANADA GOOSE.}

\section{Bernicla canadensis hutchinsi (Rich.) Coues.}

Chars. Tail usually I6-feathered. Colors exactly as in the Canada Goose, but size less. About 30.00 long; wing, 15.0017.00; tail, 5.00-6.00; bill, 1.33 $\frac{1}{3}-1.66_{3}^{2}$; tarsus rather under 3.00. North American, but chiefly northern and western.

This doubtful species may be found in New England in limited numbers. It was regarded by Nuttall as a straggler on our coast; Giraud says it is quite abundant some seasons on the coast of Massachusetts, Linsley records it from Connecticut; Coues remarks, "Spring and autumn migrant. Not abundant." Dr. Brewer regards it as formerly more abundant than at present. Mr. Merriam refers to it as "Southern Goose," and adds, "not uncommon, 'Stratford,' Conn.," (Linsley). Mr. Geo. Bird Grinnell tells me that the hunters about Milford, Conn., all make a distinction between the common or Canada Goose, and the Southern Goose; that the latter do not arrive until after the Canada Geese have all come, and that they do not stay long, but pass Southward, - hence their name" (Rev. B. Conn., I877, p. I 22).

\section{THE MALLARD.}

\section{Anas boscas Limn.}

Chars. Male : head and neck glossy-green, surrounded by a white collar; breast purplish-chestnut; tail-feathers mostly whitish; greater wing-coverts tipped with black an $l$ white; speculum violet, bordered with black; bill greenish-yellow; feet orange- 
red. Female: wing-markings as in the male; general plumage variegated with yellowish-brown and dusky; bill blotched with yellowish and blackish. Length about 24.00; extent, 36.00 ; wing, I1.00; bill, 2.40 ; tarsus, I.75.

Although so common a bird in North America at large, and one of the most widely distributed of Ducks in various parts of the world, the Mallard is rare in New England, and does not ordinarily go further eastward along the coast. It is chiefly found in winter, and during the migrations. The numerous authorities speak of the bird in similar terms, and none appear to be aware of its breeding within our limits.

We have collated the following references : - Mass., very rare, Peabody, Rep. B. Mass., 1839, p. $386 . \quad$ Essex Co., Mass., rare, Putnam, Pr. Essex Inst., i, I 856, p. 2 I 9. Essex Co., Mass., one specimen, Coues, ibid., v, I868, p. 298. Mass., rare, Allen, ibid., iv, i 864 , p. 78, and Bull. Essex Inst., x, I878, p. 27. E. Mass., rare, Maynard, Nat. Guide, I870, p. I47. Salem. Mass., R. L. Newcomb, Forest and Stream, i, p. 279. Norway, Me., rare, Verrill, Pr. Essex Inst., iii, I 862, p. I 53. Calais, Me., rare, Boardman, Pr. Bost. Soc., ix, I862, p. I29. New Brunswick, rare, Chamberlain, Bull. Nutt. Club, vii, I882, p. I05. Newport, R. I, very rare, one shot, anonymous writer in Forest and Stream, v, p. 204. Conn., a rare migrant, Merriam, Rev. B. Conn., I877, p. I 23 ; cites Linsley; cites Grinnell, Oct. and Nov., I870, and Brooks, as to its occasional presence in fall. Conn., occasional, R. E. Morris, Forest and Stream, vii, p. I I6. Maynard calls it "only a wanderer" in Bds. E. N. Am., I 88 I, p. 44I. Coues speaks of it as "far from common," in Bds. of N. W., I874, p. 560. One of the newspapers (Boston Herald of Nov. 6, I882) speaks of four Mallards 
killed by A. W. Bray at Ipswich, Nov. 5, I $\$ 82$ - the first he ever killed in twenty years' experience in gunning there.

\section{DUSKY DUCK.}

\section{Anas obscura $G m$.}

Chars. Size of the Mallard, and resembling the female of that species, but the general coloration darker; no decided white anywhere excepting the lining of the wings; speculum violet, with black bordering, without any white tipping of the coverts; bill greenish-yellow; legs red. This, as well as all the River Ducks (Anatinc), are distinguished from the Sea Ducks by having no lobe or flap on the hind toe.

The characteristic and one of the commonest Ducks of New England - a resident species, though most numerous during the migrations, when those individuals which breed farther north and winter farther south pass through. Those which do not nestle with us, come in September from the north, the flight begirining as soon as the young are grown strong of wing; and the departure from the north is completed in May. This Duck is known to breed at large in New England, but the greater number which pass the summer here resort to the swamps of Maine. "Flappers," $i$. $є$., the young before they can fly, are commonly seen in July, in broods, swimming on ponds; when molested they are very expert in eluding pursuit, by scrambling out of the water and hiding closely in the surrounding herbage. At this season, also, the old birds shed their flightfeathers; they are for a time entirely deprived of the power of flying, and may be observed skulking in 
the rank herbage about the borders of the pools, where their young were reared. The nest is commonly placed on the ground - in rare instances in the hollow of a tree, or some "stub" projecting from the water of a swamp. The eggs are creamy or pale buff-colored, smooth and elliptical, measuring two and one-third inches long by one and two-thirds of an inch in breadth; they are laid in May and June, to the number of six, eight or ten.

This is one of the largest of the river Ducks, and unsurpassed in the excellence of its flesh. Among sportsmen, its book-name of "Dusky Duck" is less often used than that of "Black Duck."

\section{PINTAIL OR SPRIGTAIL DUCK.}

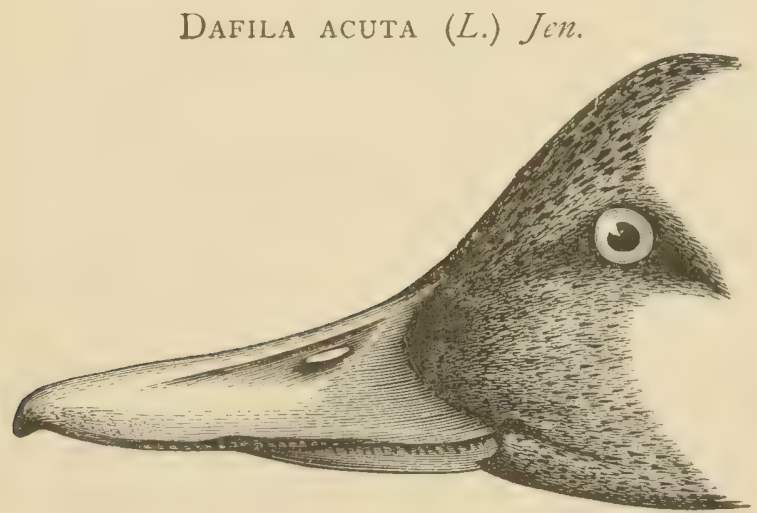

Fig. 63.- Head of Female Sprigtail. Nat. size.

Chars. Tail cuneate, when fully developed the central feathers much projecting and nearly equalling the wing in length; much shorter and not so narrow in the female and young; 4.00 to 9.00 
inches long; wing I 1.00; total length about $2400 . \quad$ Bill black and blue, feet grayish-blue; head and upper neck dark brown, with green and purple gloss; side of neck with a long white stripe; lower neck and under parts white; dorsal line of neck black, passing into the gray of the back, which, like the sides, is vermiculated with black; speculum greenish-purple, anteriorly bordered by buff tips of the greater coverts, elsewhere by black and white; tertials and scapulars black and silvery. Female and young with the whole head and neck speckled or finely streaked with dark brown and grayish or yellowish-brown; below duskyfreckled; above, blackish, all the feathers pale-edged; only a trace of the speculum between the white or whitish tips of the greater coverts and secondaries.

A winter resident, and not very common; most numerous during the migrations, and particularly in the fall.

\section{THE GADWALL.}

\section{Chaulelasmus streperus (L.) Gray.}

Chars. Male : with most of the plumage barred or half-ringed with black and white, or whitish; middle wing-coverts chestmut; greater coverts blaik, speculum white; female known by these wing-marks. Length, 19.00-22.50 ; extent, 30.00 ; wing, 10.00I1.00; bill, I.66; tarsus, I.75.

Occurring during the migrations, with some regularity, but far from common. This Duck very probably breeds in the swamps of Maine, though the fact has not been determined. The eggs are of the usual shape, of a uniform creamy-buff color, and measure a trifle over 2.00 in length by about 1.50 in breadth. 


\section{AMERICAN WIDGEON; BALDPATE.}

\section{Mareca americana (L.) Steph.}

Chars. Male: Bill shorter than head, grayish-blue like the feet; tail 14-16-feathered, pointed, but hardly or not half as long as the wing; top of head white or nearly so, plain or speckled, its sides, and the neck, more or less speckled; fore breast light brownish-red ; belly pure white ; crissum abruptly black ; middle and greater coverts white, latter black-tipped; speculum green, black-bordered. Head and neck grayish-white, speckled with dusky; top of head white, in full plumage, its sides with a broad green patch. Length, 20.00-22.00; wing, II.00; tail, 5.00 ; bill, I.33-1.50. Female recognizable by the wing-markings.

One of the regularly migratory Ducks, occurring in spring and fall, and also occasionally during the winter months; but it is not a common species. Mr. Brewster thought its recent occurrence inland, about twenty miles from the coast, worth a notice (Bull. Nutt. Club, vii, I882, p. I85). We have no evidence that it breeds with us. The eggs are eight to twelve in number, measuring about $2.00 \times 1.50$, and of a dull

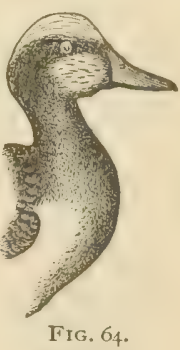
WIDGEON. pale buff color.

Note. The European Widgeon, Marcca penelope, has been found casually along the Atlantic coast, and in localities it could hardly have reached without visiting New England. But we have no knowledge of its actual occurrence. It has however been taken on Long Island. 


\section{GREEN-WINGED TEAL.}

\section{Querquedula carolinensis ( $G m$.) Stcph.}

Chars. Male : subcrested; head and upper neck chestnut, with a broad glossy green band on each sicle, whitish-bordered, uniting and blackening on the nape; under parts white, the fore breast with circular black spots; upper parts and flanks closely waved with blackish and white; crissum black, varied with white or creamy ; speculum rich green, bordered in front with buffy tips of the greater coverts, behind with white tips of the secondaries; no blue on the wing; bill black; feet gray. A conspicuous white crescent on the side of the body just in front of the bend of the wing; scapulars plain. Female differs especially in the head-markings, but those of the wings are the same. Small; length, I4.00-15.00; wing, 7.50 ; tail, 3.50 ; bill, I.50; tarsus, 1.25.

These small and elegant Ducks, notable both for the beauty of their plumage and the excellence of their

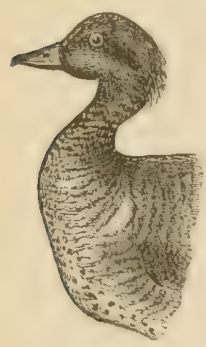

FIG. 65. - GHEEN WINGED TEAL. flesh, are among the commonest of the migratory species. They scmetimes appear in March, but more numerously in April, and are among the earliest to return in the fall, sometimes even appearing in August, and always by September. The nest is placed upon the ground, built of hay and lined with feathers; the eggs are about eight in number, pale dull greenish in color, measuring from 1.75 to 1.90 in length by $\mathrm{I} .20$ to I.3O in breadth.

Note. The Europen Teal, Q. crecca, has been erroneously attributed to New England (see Pr. Bost. Soc., v, 1855, p. I95 ; Bull. Nutt. Club, ii, 1877, pp. 13 and 46 ; Bull. Essex Inst., x, 1878, p. 34). 


\section{BLUE-WINGED TEAL. \\ Querquedula Discors (L.) Steph.}

Chars. Wing-coverts in both sexes sky-blue, the greater whitetipped; speculum green, white-tipped; axillars and most under wing-coverts white; scapulars striped with tawny and blue (not in the female) or dark green; fore back barred; rump and tail dark, plain; crissum dark or black ; bill black ; feet not dark. Head and neck of the male blackish-plumbeous, darkest on the crown, usually with purplish iridescence; a white crescent in front of the eye ; under parts thickly dark-spotted. Female with head and neck altogether different; under parts much paler and obscurely spotted; but known by the wing-marlings from any other species. Length, I5.00-16.00; wing, 7.00 ; tail, 3.00 ; tarsus, $1.25 ;$ bill, 1.50-1.67.

This kind of Teal occurs with us under the same circumstances as the Green-Winged does, but is less numerous. Mr. Allen speaks of its having formerly been, doubtless, a summer resident; but we have no late records of its breeding in New England.

\section{SHOVELLER ; BROAD-BILL.}

\section{Spatula clypeata (L.) Boie.}

Chars. Head and neck glossy-green; rump and upper tail-coverts black, faintly glossed; breast and forward under parts white; belly dark violet-red; under tail-coverts black ; more or less white on the wing, shoulders, and along the posterior parts; wingcoverts and tertials blue, more or less tipped with white ; speculum green, bordered with a stripe of black and then of white. Female darker or duller; head and neck reddish, darker below. Bill enlarged at end, nearly black. Leys and feet red. Iris orange-red. Length, 19.00-20.00; extent, nearly 30.00 ; wing, 9.00-9.75; bill, 20.00 or less; tarsus, I.40. 
This Duck, of singular figure and greatly varied plumage, is a rare migrant, chiefly along the coast. "It was formerly," says Mr. Allen, "judging from its breeding range in the interior, a frequent summer resident." This probability is strengthened by the fact that, according to Dr. Merriam, the Shoveller has been taken in Connecticut in July and August, as well as in December. It decreases in numbers from Connecticut northward and eastward.

The eggs are eight or more in number, measuring on an average 2. 10 in length by 1.20 in breadth, and are uniform dull pale greenish-gray.

\section{SUMMER, OR WOOD DUCK.}

Aix sponsa (L.) Boie.

Chars. Head crested, metallic green and purple; line above and behind eye, white; throat white also; above, coppery black with a gloss of green and purple; beneath white, throat and upper part of breast chestnut; sides buffy, very finely variegated with black; scapulars black; a white crescent in front of the shoulder bordered also with black; coverts and quills with more or fewer tips and shades of white and purple. Female: chestnut of neck detached and clull; sides not striped, head and neck dull. Bill reddish, edges dusky. Legs and feet yellowish. Iris red. Length, 19.00 ; extent, 27.50 ; wing, 9.00 ; bill, 1.40 ; tarsus, 1.50.

This, the most beautiful of the Ducks, arrayed in a plumage well-named "bridal," is a common summer resident, arriving in March and remaining into October. It is remarkable among Anatide for nesting in holes in trees, the last place one would expect a Duck to select. 
The habit, however, is not peculiar, for some of the Fuligulince do the same thing. The eggs are about a dozen in number, measuring $2.00 \times 1.50$, of a dark color, and are laid upon a bed of hay and feathers. The

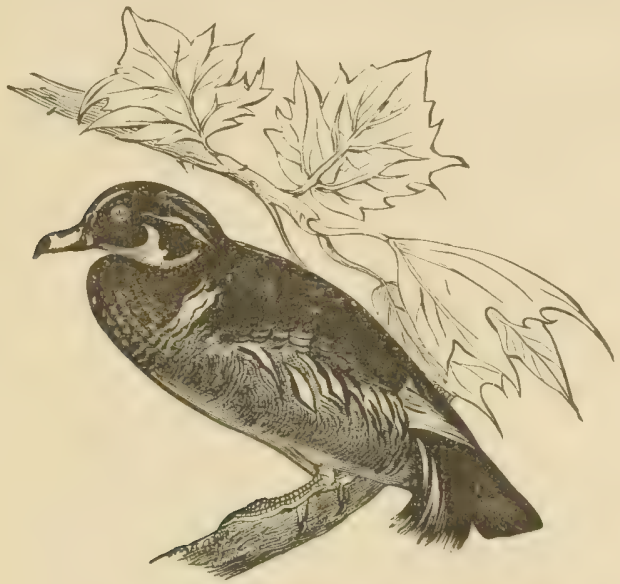

Fig. 66.-Woon Duck.

bird is the most characteristic Duck of New England, excepting the Dusky Duck; and is found generally distributed wherever there are suitable breeding-places, being by no means peculiar to the coast.

\section{GREATER SCAUP DUCK. \\ Fuligula marila (L.) Stcph.}

Chars. Male: head, neck, and body anteriorly black, the former glossy; lower back, rump, and tail blackish. Below, white, the sides and lower belly finely waved with black. Speculum white; back and sides zigzagged with white; no colored ring around neck. Bill and feet bluish, former with black nail. Female : 
head and anterior parts of the body brown, and other parts which are black in the male here brownish. Region about base of bill white. Length about 20.00 ; extent, 29.00; wing, 9.00 ; bill, 2.10 ; tarsus, I.50.

One of the winter residents along the coast, rather common at that season, but, as usual with birds of this family, more numerous during the migrations, when those that have wintered farther south, or bred in the high north, pass through New England. It is an expert diver, and usually found in flocks of considerable size.

\section{LESSER SCAUP DUCK.}

\section{Fuligula affinis Eyton.}

Chars. Very like the last; gloss of head purplish rather than green; flanks and scapulars less closely vermiculated? Size less; length about 16.00 ; wing, 8.00. Difficult to define specifically, and perhaps only a variety of the last; it appears, however, to preserve certain distinctions, though constantly associated with $F$. marila.

This Duck is doubtfully a distinct species from the last, with which it is found associated, occurring under the same circumstances. Both are properly sea-ducks, though occasionally found inland.

\section{RING-NECK SCAUP DUCK.}

\section{Fuligula collaris (Donov.) Bp.}

Chars. Male: resembling the last two species; back nearly uniform blackish; an orange-brown ring round the neck; speculum gray; bill black, pale at base and tip. Female: no 
collar ; head and neck brown, but loral space, chin, and eye-ring white. In size between the other two foregoing species of Fuligula.

Another spring and autumn visitant, not common. This is its proper category, though it may be occasionally found in winter, and is known to breed in Maine, where Mr. Boardman has found it in summer, near Calais (Am. Nat., v, I87 I, p. I2I). As to its rarity in Maine, however, see Brown, Bull. Nutt. Club, vii, I882, p. 190.

\section{RED-HEAD DUCK ; POCHARD.}

\section{Fuligula ferina americana (Eyt.) Coucs.}

Chars. Male: head and neck chestnut-red, rich and pure, with bronzy reflections. Body anteriorly, rump and tail-coverts, black; back mixed silvery-gray and black in about equal amounts; the dark vermiculations unbroken; speculum bluish-ash. Female : head plumbeous-brown; black parts of the male dark brown; vermiculations less distinct. In both sexes, bill dull blue with a black belt at end, broad and depressed, two inches or less in length; not rising high on the forehead, the nostrils within its basal half; head very puffy, the forehead convexly coming down to bill; extent of red on the neck less than in the canvas-back. Length about 20.00 ; extent, 29.00 ; wing, 9.00I0.00; tarsus, I.70.

Chiefly a migrant, and rather rare. It, however, breeds in Maine, according to Mr. Boardman (Am. Nat, $\mathrm{v}, \mathrm{I} 87 \mathrm{I}, \mathrm{p} .662$ ). It is very frequently offered for sale as canvas-back, but there should be no difficulty in discriminating the two species by the shape of the bill and the color of the head. 


\section{CANVAS-BACK DUCK.}

\section{Fuligula vallisneria (Wils.) Steph.}

Chars. Resembling the Red-head, but easily distinguished by the bill and head. Bill blackish, high at the base and narrow throughout, not shorter than head, 2.50 inches long or more, the nostrils at its middle; head much obscured with dusky; black waved lines of the back sparse and much broken up into dots, the whitish thus predominating. North America, especially abundant along the middle Atlantic Coast in winter, where from feeding on the wild celery (Vallisneria) its flesh acquires a peculiar flavor, though it is not particularly exceilent under other circumstances.

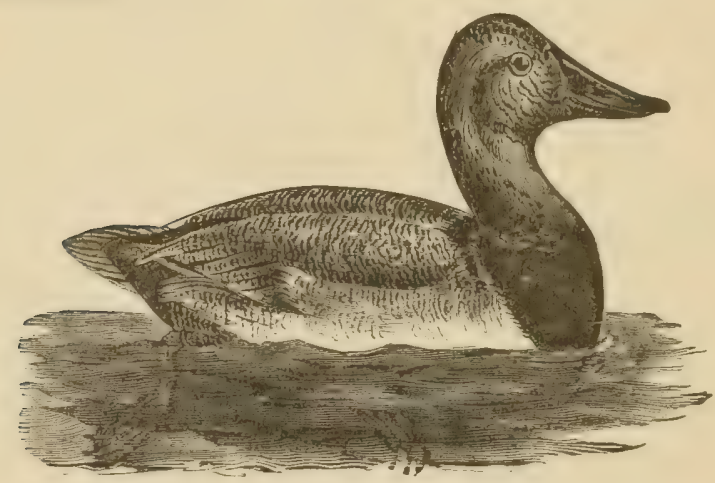

Fig. 67. - Canyas.back Duck.

Occurring with the last, under the same circumstances. Though its breeding with us has not been determined, so far as we know, the bird will probably yet be found nesting in the swamps of Maine. In the West, it is known to breed within the limits of the United States, as for example on the Turtle Mountain, in Dakota, where Dr. Coues found it nesting in 1873. 


\section{GOLDEN-EYED DUCK; WHISTLER.}

\section{Clangula glaucium (L.) Brelim.}

Chars. Male: with the head puffy, dark-colored, iridescent, with large white patches; lower neck all around, under parts, including sides, most of the scapulars, wing-coverts and secondaries, white; lining of wings and axillars dark; most of upper parts black; no waving on back and sides. Female with the head less puffy, brown or dark gray, with traces of the white patches, or not; somewhat less white on the wings; fore breast and sides with gray, the feathers paler-edged. Bill much shorter than head, very high at the base, tapering, with median nostrils. Male with the head and upper neck glossy dark green, and a white oval or rounded loral spot, not touching the base of the bill throughout; white continuous on outer surface of wing; bill black, with pale or yellow end; feet orange; webs dusky; eyes yellow. Length, I6.00-I9.00 ; extent, about 28.00; wing, 8.009.00 ; bill, I.25 ; tarsus, I.75.

The Golden-eye is resident in New England. It is chicfly known in its character of a winter visitant, but it breeds in Maine, as attested both by Mr. Boardman and Mr. Deane. The latter speaks of a nest, containing eight eggs, placed in a hollow stump at Lake Umbagog, and its nidification would appear to be usually arboreal.

\section{BARROW'S GOLDEN-EYE; ROCKY MOUN- TAIN GARROT.}

Clangula islandica $(G m$. $) B p$.

Chars. Very similar to the last; gloss of head purplish and viclet; the loral spot larger, triangular or crescentic, applied against the whole side of the bill at base; white on surface of wing divided 
by a dark bar; rather larger than the last; length, 19.00-22.00; wing, 9.00-10.00; occipital feathers lengthening into a slight crest; bill shorter. Female probably not distinguishable with certainty from that of the foregoing, unless by the dark bar on the wing.

A winter resident, rare and scarcely more than casual, in most parts of New England. It is, however, spoken of by Mr. Boardman as occurring in summer in Maine, and Dr. Brewer so marks the species in his list, doubtless upon this authority. It may not be so scarce as it is supposed to be on the Maine coast, seeing how likely it is to be confounded with $C$. glaucium by the gunners. It is so rare in southern New England as to have been only recently added to the Massachusetts fauna by actual capture of a specimen on Cape Cod, Dec. 7, 1870, as noted by Mr. Brewster (Am. Nat., vi, I 872 , p. 306), who adds that he has also seen numbers in the Boston markets, mostly from the same State. A Connecticut case is reported by Dr. Merriam; that of an adult male in possession of Mr. J. H. Sage, of Portland, who purchased it Nov. I4, 1867, from a man who said it had been killed on the Sound (Rev. B. Conn., 1877 , p. 126).

\section{BUFFLE-HEAD DUCK. \\ Clangula albeola (L.) Stcpll.}

Chars. Pattern of coloration of the foregoing. Male with the head particularly puffy, of varied rich iridescence, with a large white auricular patch confluent with its fellow on the nape. Small; 14.00-16.00; extent, 22.50; wing, 6.00-7.00; bill about 1.00, with nostrils in basal half; female still smaller, an insignificant looking duck, with head scarcely puffy, dark gray, with traces of the auricular patch. 
A common winter resident, arriving in October, and remaining into April. "The Buffle-head is not often seen in the United States, except from fall to spring; as it usually retires to high latitudes to breed, as along the Yukon and elsewhere in boreal America, its nidification is consequently not generally known. A set of fourteen eggs taken, the accompanying label states, from a feathery nest in a dead poplar, some distance from the ground, furnishes the following description: Shape, perfectly ellipsoidal; size, slightly over 2.00 inches in length by 1.50 in breadth; color, a peculiar tint, just between rich creamy-white and grayish-olive, unvaried by markings. Other eggs are described as being about I.67 long by 1.25 broad, and buff-colored " (Coues, Birds Northwest, 1874, p. 578).

\section{LONG-TAILED DUCK.}

\section{HARELDA Giacialis (L.) Leach.}

Chars. Tail of fourteen narrow pointed feathers, in the male in summer the central ones very slender and much elongated, nearly or quite equalling the wing; nail of bill occupying the whole tip; seasonal changes remarkable. Male in summer with the back and the long, narrowly lanceolate scapulars varied with reddish-brown, wanting in winter, when this color is exchanged for pearly-gray or white; general color blackish or very dark brown, below from the breast abruptly white; no white on the wing; sides of head plumbeous-gray; in winter, the head, neck and body anteriorly, white, but the gray cheekpatch persistent, and a large dark patch below this ; bill at all seasons black, broadly orange-barred. Female without lengthened scapulars or tail-feathers, the bill dusky greenish, and otherwise different, but recognized by presence of head and 
neck patches, and absence of white on the wing. Length, I5.0020.00 , or more, according to tail ; extent, 28.00; wing, 8.009.00 ; bill, I.10; tarsus, 1.50 .

An abundant winter resident all along the coast, and even more numerous during the migrations, arriving in October, and remaining until April. The following interesting paragraph is cited from Dr. Merriam: "This is by far the most abundant species of Duck found along our coast, and during the migrations (notably in Norember) hundreds of thousands of them can be seen on the Sound, covering the waters as far as the eye can reach in every direction, and almost deafening one by their constant, and to my ears not altogether unpleasant, cackle. They are continually on the move, and, notwithstanding their immense numbers, it is no easy task to approach within gunshot of the flock. Though as strictly maritime as any of our ducks, they have occasionally strayed so far into the interior as Ohio (Wheaton). Mr. Grinnell tells me that they occasionally breed here, but these may be wounded birds, - 'pensioners,' as they are commonly called” (Rev. B. Conn., I877, p. I26). Mr. H. Herrick thinks they may breed at Grand Menan, N. B., where he has known them to be shot June I 8 (Bull. Essex Inst., v, I873).

\section{LABRADOR OR PIED DUCK.}

\section{Camptolmuds labradorius (Gm.) Gray.}

Chars. Bill enlarged towards end by membraneous expansion, the nostrils in its basal third; cheek-feathers rigid. Male with the body and primaries black; rest of the wing, with neck and 
head, white, with a black collar and lengthwise coronal stripe. Female plumbeous gray. About 2 feet long; extent, 32.50; wing, 9.00 .

One of the earliest notices of this rather celebrated duck, a portrait of which adorns the title-page of Pennant's Arctic Zoology, published in 1785 , speaks of it

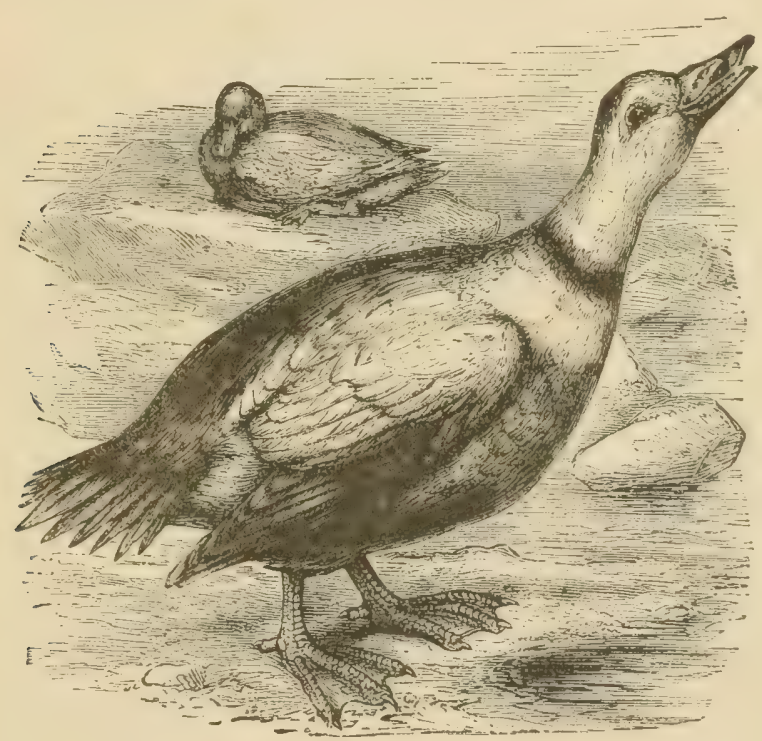

Fig. 68. - Labrador DUCK.

as having been sent from Connecticut to Mrs. Blackburn, an English lady best known to our ornithologists by the association of her name with one of our most beautiful Warblers. The Duck appears to have formerly been a common bird, but it has become exceedingly rare, and the species is supposed to be near extinction. 
Mr. Allen, in his Review of "G. D. Rowley's monographic essay on the Labrador or Pied Duck," says: "While apparently of rather frequent occurrence along the Atlantic coast, as far south at least as Long Island, New Jersey, and Delaware, fifty to thirty years ago, it has of late been rarely observed, and few specimens appear to have been taken since I868. Its last recorded capture, as appears from a letter from Mr. George N. Lawrence, published in Mr. Rowley's paper, seems to have occurred "in the fall of 1874 ," when a specimen was obtained by Mr. J. Wallace, from Long Island, from which source the same gentleman had obtained four or five others during the five previous years. All were females or immature males, and only one adult male is known to have been taken in the last twenty years." He adds that the number of specimens known to be extant are "only thirty-three, of which about twenty are preserved in different collections in the United States, and the remainder in European museums. About onehalf are adult males, and most of the remainder adult females. The localities, so far as known, are Long Island, N. Y., thirteen specimens ; Calais, Me., two ; Halifax harbor, one; 'Labrador, one'; and one is recorded from Delhi, Michigan, eighteen in all, leaving fifteen from unknown localities" (Bull. Nutt. Club, iii, I878, p. 79).

Dr. Brewer remarks that the Pied Duck was "abundant" in Boston market from that vicinity in $1836-37$ (Bull. Nutt. Club, ii, I877, p. 46). Mr. Boardman speaks of its being formerly common in the Bay of Fundy (Forest and Stream, vi, I876, p. I8r ; see also Am. Nat., iii, I869, p. 383). Three individuals are noted in Nova Scotia in 1850 (Orn. and Oöl., vii, 1882, p. 122). Mr. H. Herrick speaks of a male shot in April, 1871 , at 
Grand Menan, N. B. (Bull. Essex Inst., v, I873, p. I3 of separate issues). We may also refer to the record given by Dr. W. H. Gregg, of the occurrence of the rare bird near Elmira, Chemung Co., N. Y., Dec. I2, I878 (Am. Nat., xiii, 1879, p. 128).

\section{HARLEQUIN DUCK.}

\section{Histrionicus minutus (L.) Cones.}

Chars. Bill very small and short, with a membraneous lobe at base, rapidly tapering to tip, which is wholly occupied by the fused nail. Tertiaries curly; plumage singularly patched with different colors. Male: deep leaden bluish, browner below; sides of head, and of body behind, chestnut; coronal stripe and tail black; a white patch at base of bill, one on side of occiput, of breast, and of tail ; two transverse ones on neck nearly forming a collar, and several on wings; a white jugular collar. Speculum violet-purple. Female: dark brown, pale below, whitening on belly; a white patch on auriculars and before eye. Length, I 5.00-18.00; extent, 27.00 ; wing, 8.00 ; bill, 1.00 ; tarsus, I.40.

An extremely rare winter visitor. Mr. Boardman remarks: "A few apparently somewhat disabled individuals breed on the islands," that is, on the Maine coast and about the bay of Fundy. Mr. Purdie records the species from Hampton, N. H., Nov., I872. Mr. Allen gives it as a "winter visitor; not common." There is no doubt that it still occurs irregularly on our coast, though much more rarely than in former days. Mr. Merriam does not give it from Connecticut, and I can find no recent records of its capture. Mr. Herrick says of it at Grand Menan: "Common in winter. It is noted among gunners for its diving propensities, it 
being almost impossible to shoot one sitting on the water, as they go under at the flash. I do not think it breeds now, though it may have done so in years past." See Brewer, Bull. Nutt. Club, ii, I877, p. 46 ; Allen, Bull. Essex Inst., x, I878, p. 27 ; Boardman, Pr. Bost. Soc., ix, I 862 , p. I 30.

\section{EIDER DUCK.}

\section{Somateria mollissima Dresseri (Sharpe) Coues.}

Chars. Bill not feathered to the nostrils, with long club-shaped processes extending in a line with the culmen upon the sides of the forehead. divided by a broad feathered interspace. Male in breeding attire white, creamy-tinted on breast, and washed with green on head; under parts from the breast, lower back, rump, tail, quills, and large forked patch on the crown, black. Female with the bill less developed; general plumage an extremely variable shade of reddish-brown or ochrey-brown, speckled, mottled and barred with darker; male in certain stages resembling the female. Length, about 2 feet; extent, 35.00; wing, 11.00-12.00; bill of male, 3.00 ; tarsus, 1.75 .

This celebrated bird, semi-domesticated in some places, yields most of the prized eider-down of commerce, which the parent plucks from the breast to cover the eggs.

Though given in Dr. Brewer's catalogue of I 875 only as a "winter visitant," the Eider Duck is resident in New England, breeding sparingly on the Maine coast eastward (Boardman, Pr. Bost. Soc., ix, I862, p. I 30), and in winter extending its range beyond Connecticut. Mr. Purdie informs us that to his knowledge it nests on the Maine coast at least as far westward as Mt. Desert. 
It is exclusively maritime, and not abundant at any season, though very common further east and north, being one of the most characteristic summer birds of Labrador and Newfoundland. The nest is built on the

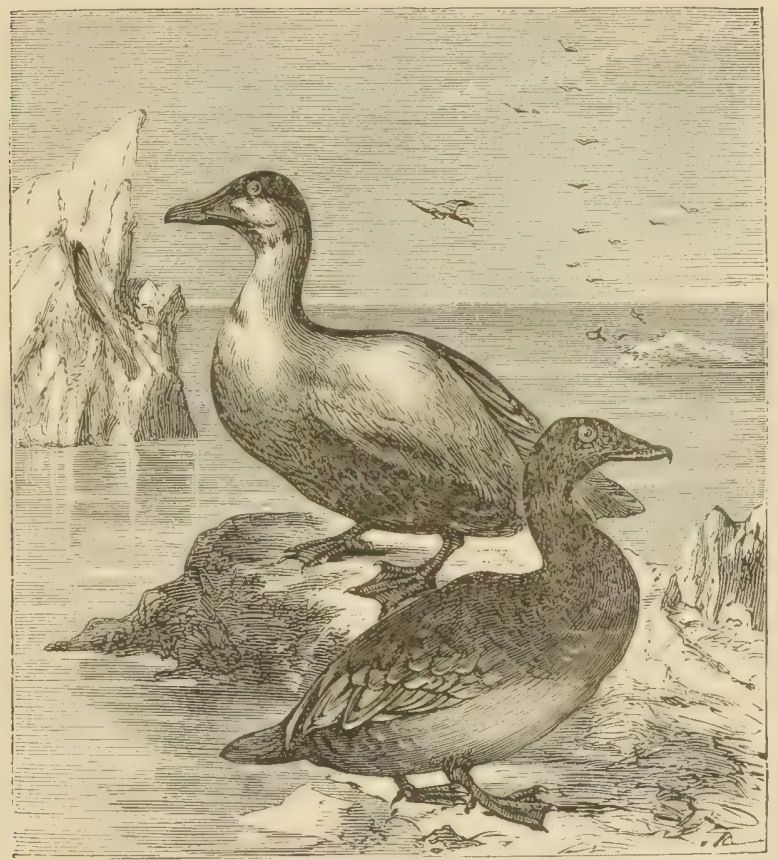

Fig. 69. - Eider Dúcks.

ground, and consists chiefly of mosses, lichens, hay, and seaweed, to which are added the feathers which the bird plucks for that purpose; the eggs are six to ten in number, but often fewer, plain dull greenish-drab, measuring about 3.00 by 2.00 . They are laid usually in June and the early part of July. 
ANATIDAE: SWANS, GEESE, AND DUCKS.

\section{KING EIDER DUCK.}

\section{Somateria spectabilis (L.) Boie.}

Chars. Bill with broad, squarish, nearly vertical frontal processes bulging angularly out of line with the culmen proper. Male in breeding attire black, including a forked chin-patch, a frontal band, and space around eye. Neck and fore parts of the body, part of the interscapulars, of the wing-coverts, and of lining of wings, together with a flank patch, white; creamy on the jugulum; greenish on the sides of the head, the crown and nape fine bluish-ash. Female resembling that of the common Eider, but bill differently shaped. Size of the last, or rather less.

A rare winter visitor along our whole coast. Linsley speaks of two Connecticut examples, Giraud gives the bird as from Long Island, and Coues ascribes a range from the Arctic coast to New York. A copy of Boardman's Calais list in the possession of Mr. Purdie is annotated in manuscript with the remark, that the King Eider breeds in that vicinity. Allen notes what appears to have been an irruption of King Eiders on Lake Erie, near Buffalo, N. Y., in November, I879, when at least eighteen individuals were shot.

\section{AMERICAN BLACK SCOTER.}

\section{CEdemia americana (Wils.) Sw.}

Chars. Bill scarcely encroached upon by the frontal feathers, shorter than the head, the gibbosity superior, circumscribed, orange (male); nostrils at its micldle; tail normally I6feathered. Plumage of male entirely black. Female sootybrown, paler below, becoming grayish-white on the belly, 
there dusky-speckled, on the sides and flanks dusky-waved; throat and sides of head mostly continuous whitish; bill all black; feet livid olivaceous, with black webs. Male nearly 2 feet long; wing about Io inches; female I8.00-19.00 inches; wing, 8.00-9.00; gape, 2.00; culmen, 1.75. Differs from the European in the shape and coloration of the protuberance on the bill.

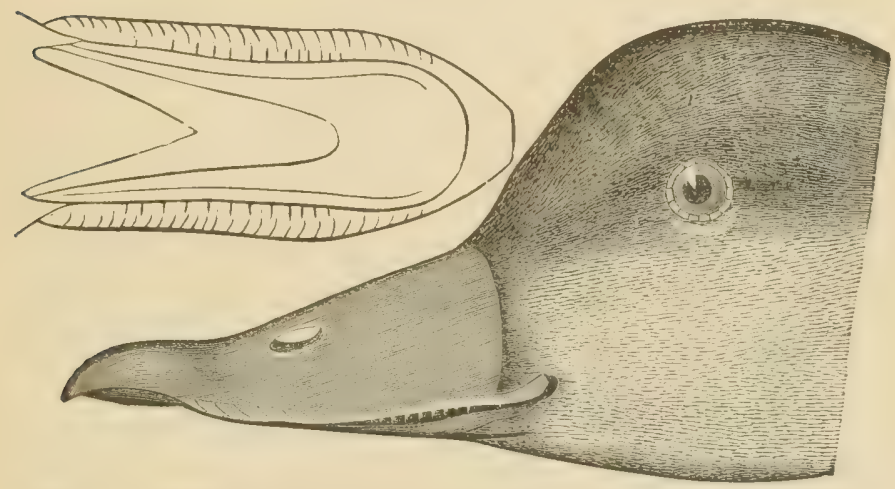

Fig. 7o. - Female Black Scoter, with Outline of Bill from Below.

A winter resident along the coast, not very common, but more so during the autumnal and vernal migrations. Like the rest of the genus it is a sea-duck, occurring inland only exceptionally or upon the larger bodies of water.

\section{VELVET DUCK : WHITE-WINGED SCOTER.}

\section{CEdemia fusca (L.) Siv.}

Chars. Bill broadly encroached upon by the frontal feathers, on the culmen nearly or quite to the nostrils, and on its sides to a less extent, shorter than head, black, broadly orange-tipped 
(male); nail broad and truncate; gibbosity superior, circumscribed. Male black, with a large white wing-patch, and another under the eye; feet orange-red, with dusky webs. Size of the the last, or rather larger. Female smaller, sooty-brown, pale grayish below, with much whitish about head, but showing white speculum; bill all black. Said to differ from the European by greater encroachment of feathers on bill, but the ascribed feature is not tangible.

This is the most numerous of the three species of the genus, occurring as a winter visitant, and still more abundantly during the migrations. It usually appears during the latter part of September, and works its way southward by October, some individuals remaining until well into May of the following spring. It is strictly maritime, only exceptionally seen away from the coast. It would appear that during the migrations the old birds, or perhaps the old males, move apart from the others. The bill being differently shaped and colored in these cases, some gunners have supposed that there is more than one species. All the members of this genus are often called "Coots," or "Sea-Coots," with other epithets designating the different species.

\section{SURF DUCK; SEA-COOT.}

\section{CEdemia perspicillata (L.) Stcph.}

Chars. Bill narrowly encroached upon by the frontal feathers, on the culmen nearly or quite to the nostrils, but not at all upon its sides, about as long as head, with the nail narrowed anteriorly, the swelling lateral as well as superior; nostrils beyond its middle; bill of male orange-red, whitish on the sides, with a large circular black base. Plumage of male black, with a white 
patch on forehead and another on nape; none on the wing. Size of $Q E$. anericana; gape of bill about 2.50. Female smaller; bill black, shorter, gape about 2.25 ; feathers of culmen hardly or not reaching nostrils; feet dark, tinged with dusky-reddish; webs black; plumage sooty-brown, below silvery-gray, sides of head with much whitish, chiefly in two patches, one loral, the other auricular.

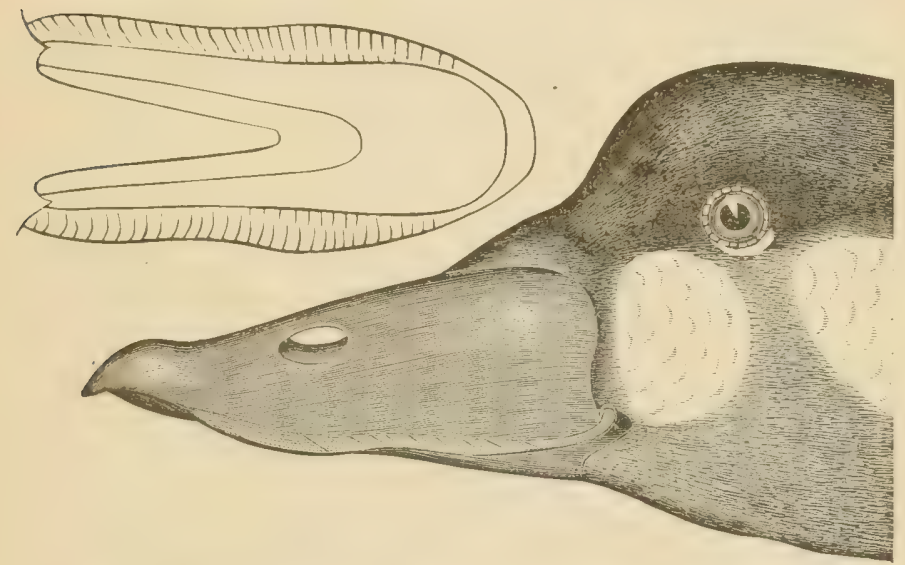

Frg. 7t. - Young Male Surf Duck, with OUti.ine of Bill from below.

A migrant and winter visitant, in numbers intermediate between those of the other species of the genus, the circumstances of its appearance, however, being the same. Dr. Brewer notes them all as "migratory" only, ignoring their winter residence. Any of them may be casually found during the whole year; but none appear to be properly estimable as summer residents or breeders in New England. 


\section{RUDDY DUCK.}

\section{Erismatura RUBIDA (Wils.) $B p$.}

Chars. Remarkably distinguished from other Fuligulina by the stiffened, linear-lanceolate tail-feathers (sixteen to twenty in number), exposed to the base by reason of extreme shortness of the coverts; bill broad, flattened, the nail large, overhanging. The male in perfect plumage with the neck all round and the upper parts brownish-red, the lower parts silky silvery-white watered with dusky, the chin and sides of the head dead-white, the crown and nape black; but not often seen in this condition in the United States. As generally observed, and the female at all times, brown above, finely dotted and waved with dusky, paler and duller below, with darker undulations, and sometimes a slight tawny tinge, as also occurs on the sides of the head; crown and nape dark brown; bill dusky; crissum always white.

Common, chiefly in the character of a migrant, in spring and fall. As correctly given by Allen, for Massachusetts, it is a winter visitant, and Coues remarks that some individuals may breed in northern New England, while Brewer only gives it as a migratory species. Mr. Hiram Cutting saw an old bird and three young at Lake Memphremagog, in Vermont, where it probably bred.

\section{ST. DOMINGO DUCK.}

\section{Nomonyx dominica (L.) Ridg.}

Chars. Male: head anteriorly and chin black; hind-head, neck, and breast deep ferruginous; above, brownish-red, blotched with black; below, lighter ferruginous; speculum white. $\mathrm{Fe}$ male similar, but less strongly marked. Length, 13.50; wing, 6.25 ; tail, 3.75 ; bill, 1.33 , smaller and less expanded than in the preceding. 
South America and West Indies, accidental in the United States. The only known instances are Lake Champlain (Cabot, Proc. B. S. N. H., vi, 375) ; Wisconsin (Kumlein; ibid. xiv, I54; Am. Nat. v, 44r).

\section{MERGANSER ; GOOSANDER; FISH DUCK.}

\section{Mergus merganser $L$.}

Chars. Bill not shorter than head, mostly red; nostrils nearly median; frontal feathers reaching beyond those on sides of bill. Male with the head scarcely crested, glossy green; back and wings black and white, latter crossed by one black bar; under parts salmon-colored. Length, about 24.00 ; extent, 36.00 ; wing, I r.00; tail, 5.00 ; bill, 2.25 ; tarsus, I.75. Female smaller; occipital crest better developed, but still flimsy; head and neck reddishbrown; black parts of the male ashy-gray; less white on the wing; under parts less tinted with salmon.

The three species of Mcrganser which occur in New England, as in most other parts of the United States, have substantially the same character, being chiefly migrants and winter residents, but also breeding in northern sections. Mr. Boardman records the present species as breeding in trees about Calais, Maine, and Mr. J. H. Sage notes its breeding at Moosehead Lake, in Maine (Orn. and Oöl., vi, IS8I, p. 5I). They are all chiefly maritime, but also found inland. All three breed in Maine, at least as far south as Umbagog Lake, where eggs have been procured, and Mr. Allen thinks Audubon had good grounds for stating that the present species has bred in Massachusetts. 


\section{RED-BREASTED MERGANSER.}

Mergus serrator $L$.

Chars. Nostrils sub-basal: frontal feathers not reaching beyond those on sides of bill; a long, thin, pointed crest in both sexes. Smaller than the foregoing; wing, 8.00-9.00. General coloration and sexual differences the same, but male with the jugulum and forebreast rich reddish-brown streaked with black; sides of the body conspicuously and finely waved with black; a white, blackbordered mark in front of the wing, which is crossed by two black bars.

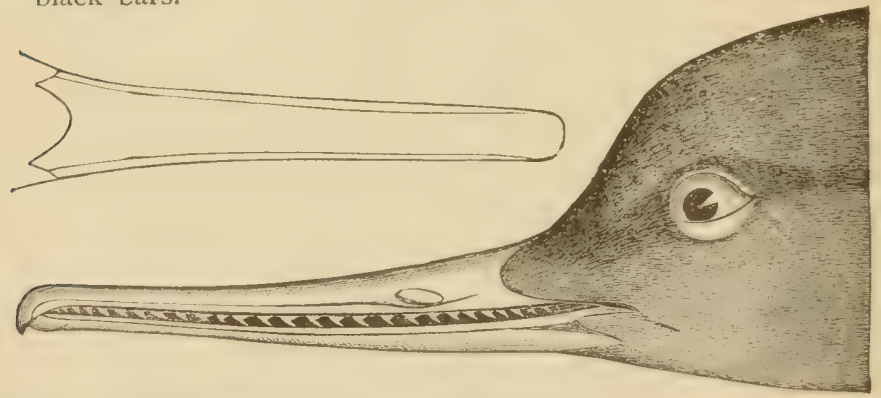

Fig. 72. - Red-breasted Merganser, witu Outline of Bill from above.

This is the commonest one of the three, especially along the coast. The figure represents the bill of natural size, and shows the sub-basal position of the nostrils, which are more median in M. merganser. The nest is placed on the ground; carefully concealed in rank herbage; it is neatly constructed of mosses, lichens, hay and seaweeds, and warmly lined with down from the parent's breast. The eggs are some nine or ten in number, of a fine creamy buff color, oval or ellipsoidal, measuring about $2.50 \times 1.65$. 
In our latest list of Maine birds, which has not reached us until this work is nearly completed, Mr. N. C. Brown notes this species as abundant in the vicinity of Portland, and, like the last, chiefly a migrant. He is however informed by $\mathrm{Mr}$. Brewster that it winters in considerable numbers as far north-east as Point Lepreaux, N. B. (Pr. Portl. Soc. Nat. Hist., Dec. 4, I 882.)

\section{HOODED MERGANSER.}

\section{Mergus cucullatus $L$.}

Chars. Bill shorter than head, mostly or entirely black; nostrils sub-basal ; frontal feathers reaching far beyond those on sicies of bill; a compact, erect, semicircular, laterally compressed crest in the male, smaller and less rounded in the female. Male: Black, including two crescents in front of wing, and bar across speculum; under parts, centre of crest, speculum, and stripes on tertials, white; sides chestnut, black-barred. Length, I8.oo19.00; wing, 8.00. Female smaller; head and neck brown; chin whitish; back and sides dark brown, the feathers with paler edges; white on the wing less; bill reddish at base below.

The rarest of the three, excepting probably in places where it breeds. This may be anywhere in New England, but as far as known is chiefly in the swampy wooded northern portions. The nest is built in the hollow of a tree or stump. According to Mr. J. G. Rich, as noted by Mr. Maynard, it breeds not uncommonly on Lake Umbagog, where Mr. Deane has taken the eggs. 


\title{
FAMILY SULID $Æ$ : GANNETS.
}

COMMON GANNET; SOLAN GOOSE.

\author{
Sula bassana $(L$.
}

Chars. Bill rather longer than the head, cleft to beyond the eyes, very stout at the base, tapering and a little decurved toward the tip, which however is not hooked; the tomia irregularly serrate, or rather lacerate; nostrils abortive; gular sac little developed, but naked; wings rather long, pointed; tail long, stiff, wedgeshaped, 12-I4-feathered; feet more nearly beneath centre of equilibrium than in some other families of this order. General configuration somewhat that of a goose; body stout; neck rather long; head large, uncrested; plumage compact. Adult : White, with black primaries; the head washed with amberyellow; bill not yellow; lores, sac, and feet blackish. Young: dark brown speckled with white, below from the neck grayishwhite, each feather darker edged; quills and tail blackish. Length, about 31.00 ; extent, 60.00 ; wing, 17.00-21.00 ; tail, about I0.00; bill, 4.00 .

Leaving now the long array of Ducks, which we have passed in rapid review, it being necessary to condense our notices in some cases in order to bring all the birds of New England within the compass of two small volumes, we enter upon a group of web-footed birds which are distinguished by having all four of the toes palmated. This order of Steganopodes, or Totipalmati, includes the six families of the Gannets, Pelicans, Cormorants, Anhingas, Frigates, and Tropic-birds, all but the last of which furnish representatives in New England.

The Gannet occurs in winter along our whole coast, 
more sparingly southward than in the opposite direction. A few still breed on a "Gannet rock" off the Maine coast, and the bird is common on the fishinggrounds. This rock lies to the southward of Grand' Menan Island, at the mouth of the Bay of Fundy. There is also a rock called by the same name lying to the southwest of Yarmouth, Nova Scotia. The great breeding resort of the species are Bird Rocks, in the Gulf of St. Lawrence, and Bonaventura Island, in the same gulf, near Gaspé.

"The herring fishermen who used to resort to the Magdalens in early spring," says Capt. J. W. Collins, "captured the bird by the ingenious device of a board painted water-color, to the upper surface of which was fastened a number of herring. This board was then anchored at some distance from the shore: the birds perceiving the lure, dashed down upon it, and broke their necks."

\section{BROWN GANNET; BOOBY.}

\section{Sula leucogastra Bodd.}

Chars. Form like that of the foregoing, but coloration very different, being brown; below from the neck white; bill and feet yellow. Young: grayish-brown, merely paler below; bill dusky. Rather smaller than the last.

This is a southern species, - one perfectly authenticated, however, as a casual visitor in New England. It was given from Guilford, Conn, by the Rev. Mr. Linsley, many years ago (Am. Jour. Sci., xliv., I843, p. 27 I). In I 56 , Mr. Putnam recorded it for Massachusetts ( $\mathrm{Pr}$. 
Essex Inst., i, I856, p. 221). Notwithstanding these cases, which Dr. Coues allows, and Mr. Purdie thinks good (Bull. Nutt. Club, i, I876, p. 72 ; ii, 1877, p. 14), Dr. Brewer excludes it from his catalogue of 1875 , with the remark that he prefers to place it on probation and await further proof (Pr. Bost. Soc., xvii, I875, p. 453). This proof he has the pleasure of producing himself, a specimen having been shot on Cape Cod, Sept. I7, I878, and brought to the Boston market, whence it passed into the possession of the Messrs. E. O. and O. Bangs, of Boston (Bull. Nutt. Club, iv, I879, p. 19I). On the alleged imperfection of the early record, see $\mathrm{Pr}$. Bost. Soc., xx, 1879 , p. 276. 


\section{FAMILY PELECANID瓜: PELICANS.}

\section{AMERICAN WHITE PELICAN.}

\section{Pelecanus trachyrhynchus Lath.}

Chars. Bill several times as long as the head, comparatively slender, but strong, straight, broad, flattened, ending with a distinct claw-like hook; mandibular rami joining only at their apex; the long, broad interramal space, and the throat, occupied by an enormous membranous sac; nostrils abortive; wings extremely long, in the upper and fore-arm portions as well as the pinion, with very numerous remiges; tail very short, of twenty or more feathers; feet short, very stout. Size large. Color white ; occiput and breast yellow ; primaries, their coverts, bastard quills, and many secondlaries, black; bill, sac, lores and feet yellow. About 5 feet long; expanse, 7.00-9.00; wing, 2.00 ; bill, I.00 or more ; tail, 0.50 , normally 24 -feathered.

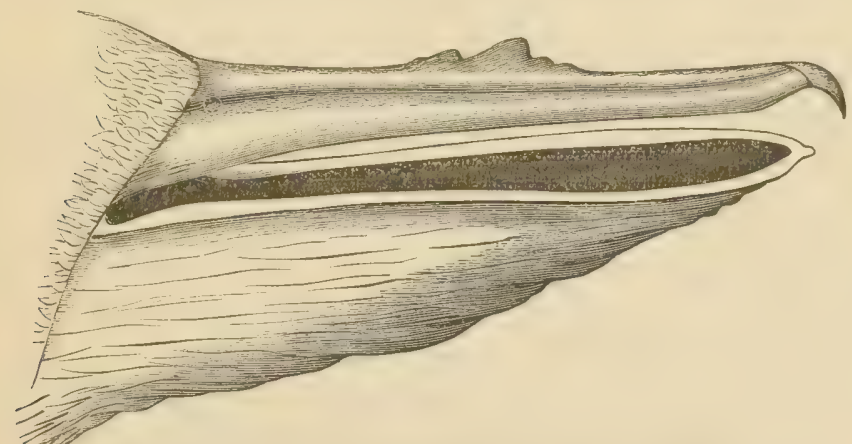

Fig. 73. - Bill of White Pelican; much Reduced.

According to Allen (Bull. Nutt. Club, i, I876, p. 60), the White Pelican was doubtless in early times not uncommon in Massachusetts and other parts of New 
England, where, however, its presence now can only be considered accidental, though there are some recent records of its occurrence. The individuals noted by him (Am. Nat., iii, I870, p. 640) as having visited Nantucket Island were later determined to have been Brown Pelicans. Mr. Purdie gives the first recent record of the capture of a White Pelican, at North Scituate, Oct. 6, I876 (Bull. Nutt. Club, ii, Jan. I877, p. 22). This is probably the first definite modern instance for Massachusetts, and the second for New England; Mr. Boardman's remark, "accidental, in one or two cases," being the only other (Pr. Bost. Soc., ix, I862, p. I30). There is a New Brunswick case, of one and perhaps two specimens (Chamberlain, Bull. Nutt. Club, vii, I882, p. I06).

\section{BROWN PELICAN.}

\section{Pelecanus fuscus $L$.}

Chars. Form like that of the last species. Plumage dark-colored, variegated; neck of the adult mostly reddish-brown; head mostly white; bill dark, varied with red; sac blackish; feet black. Rather smaller than the last. Tail normally 22 -feathered; bill without any upright horny process.

Accidental, New England being entirely beyond the usual range of this species. According to Maynard, "Mr. J. F. Le Baron is confident of having seen two of this species at Ipswich some years ago" (Nat. Guide, I870, p. I49). Allen says that a flock of five Brown Pelicans visited Nantucket a few years before i 870 , one of them being shot. Mr. Allen's slip of referring this case to the preceding species is corrected on p. 40 of the extras of his paper in Am. Nat., iii, I870, p. 640. (See ibid., iv, p. 58.) 


\section{FAMILY PHALACROCORACID $A$ : CORMORANTS.}

\section{$\longrightarrow$ \\ COMMON CORMORANT.}

Phalacrocorax carbo (L.) Leach.

Chars. Bill about as long as head, stout, more or less nearly terete, strongly hooked at the end; tomia generally found irregularly jagged, but not truly serrate; a long, narrow nasal groove, but nostrils obliterated in the adult state; gape reaching below the eyes, which are set in naked skin. Gular pouch forming an evident naked space under the bill and on the throat, encroached upon by the feathers on the middle line so that it is heart-shaped behind. Wings short for this order, stiff and strong, the second primary usually longer than the third, both these exceeding the first. Tail long, large, fan-shaped, of fourteen very stiff, strong feathers, denuded to the base by extreme shortness of the coverts. Plumage glossy greenishblack; feathers of back and wing-coverts bronzy-gray, blackedged; quills and tail grayish-black; gular sac yellow, white-bordered; feet black; in summer a white flank patch, numerous long thready white plumes on head and neck, and a small black occipital crest. Length, 36.00; wing, I2.00-14.00; tail, $6.00-7.00$; tarsus over 2.00 ; bill, 4.00 along the gape.

Rather common off the coast during the fall and winter months. A few also breed at Grand Menan. Mr. Hiram Cutting records a specimen taken in Vermont. 


\section{DOUBLE-CRESTED CORMORANT.}

Phalacrocorax dilophus (Sw.) Nutt.

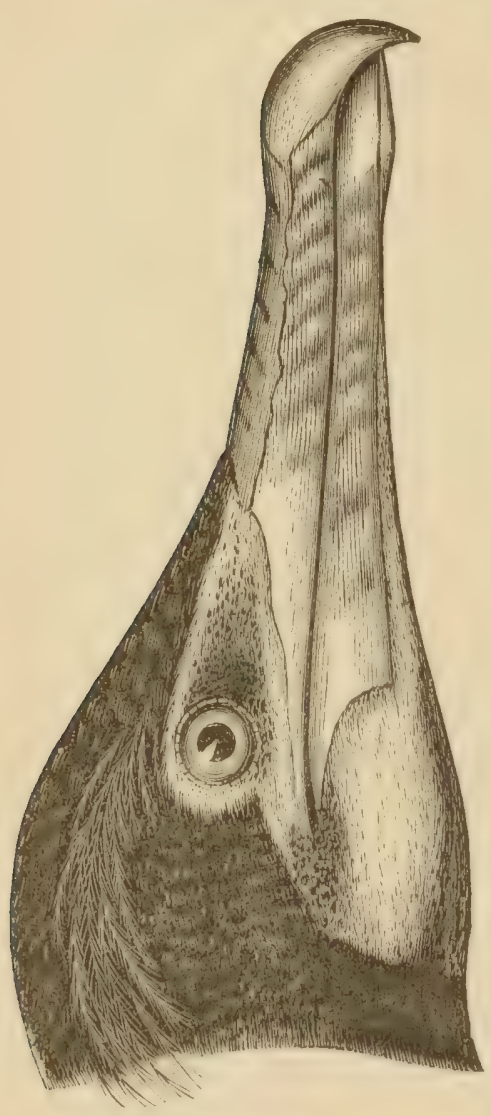

Chars. Tail of twelve feathers.

- Gular sac convex behind. Plumage glossy greenishblack; feathers of the back and wings coppery-gray, black-shafted, black-edged; adult with curly black lateral crests, and in the breeding season other filamentous white ones, over the eyes and along the sides of the neck; white flank-patch not observed in the specimens examined, but probably occurring ; gular sac and lores orange. Length. 30.00-33.00 inches; wing, I 2.00 or more; tail, 6.00 or more ; bill along gape, 3.50 ; tarsus a little over 2.00. Young plain dark brown, paler or grayish (even white on the breast) below, without headplumes.

This is the Cormorant most widely diffused in North America, and one which occurs in New Fig. 74. - Double-crested Cormorant. England under circum-
Natural size.

stances similar to those under which the preceding species is found. 


\section{FAMILY TACHYPETID偓: FRIGATES.}

\section{FRIGATE, OR MAN-OF-WAR BIRD.}

\section{Tachypetes aquilus ( $L$. $) \quad V$.}

Chars. Bill Jonger than head, stout, straight, wider than high at the base, thence gradually compressed to the strongly hooked extremity. Nostrils very small, linear, almost entirely closed, in a long, narrow groove. Gular sac small, but capable of considerable distension. Wings exceedingly long and pointed, of about thirtyfour remiges, of which the ten primaries are very powerful, with stout quadrangular shafts; upper and middle portion of the wings greatly lengthened. Tail very long, deeply forked, of twelve strong feathers. Feet exceedingly small,

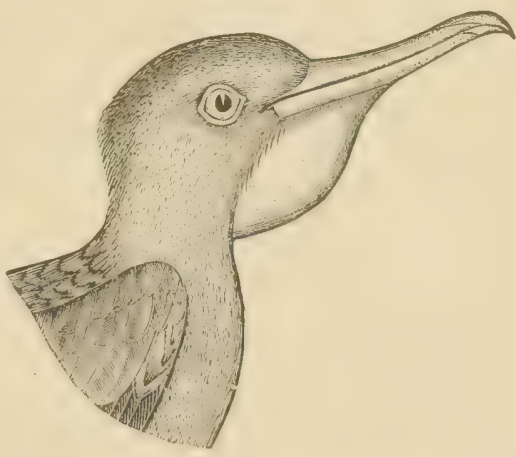

Fis. 75. - HEAd of Frigate Bird.

the tarsus, in particular, extraordinarily short, feathered; middle claw pectinate. Bulk of body slight compared with the great length of the wings and tail. Male brownish-black, glossed with green or purplish, duller on the belly, wings showing brown and gray; female with white on neck and breast. Length, about 3.50 feet ; extent, about 8.00 ; wing, 2.00 ; tail, I.50; bill, 5.00 or 6.00 inches; tarsi, 1 inch or less.

Accidental, in one known instance. Mr. George Bird Grinnell narrates that a female of this species was killed 
on Faulkner's Island, Conn., in the autumn of I859, and preserved in the collection of Captain Brooks (Am. Nat., ix, I 865, p. 470. See also Merriam, Rev. B. Conn., I877, p. I3I ; Brewer, Pr. Bost. Soc., xix, I878, p. 308). Mr. Purdie's manuscript informs us that a specimen was taken, but not preserved, about twelve years ago, at Booth Bay, Maine. A Nova Scotian case is recorded by Deane (Bull. Nutt. Club, iv, I879, p. 64); probably the same as given by Gilpin (Orn. and Ool., vol. vii, I 882 , p. I 23).

It may be mentioned that a Tropic-bird has been known to occur in Nova Scotia and New York. 


\section{FAM. LARIDAE: JAEGERS, GULLS, TERNS AND SKIMMERS.}

\section{SKUA JAEGER.}

\section{Stercorarius skua (Briinn.) Cones.}

Chars. Bill shorter than middle toe without its claw; tarsus shorter than middle toe and claw. Central rectrices broad to the tip, little projecting beyond the rest. Very large; length about 24.00 ; wing, 17.00 ; tail, 6.00 ; tarsus, 2.75 ; middle toe and claw, 3.00 ; bill about 2.00, its depth at base 0.75 . Plumage above blackish-brown, varied with chestnut and whitish; throat and sides of neck yellowish-brown, streaked with white; below, fuscorufous, with an ashy shade; quills blackish, with white shafts and a conspicuous large white area at base; tail-feathers blackish, white at the base ; very old birds are much darker and more uniform brown, almost blackish above, rather smokybrown below.

Though allowed a place in the New England list for many years, upon more or less unsatisfactory evidence, this species was with many others eliminated in 1875 by Dr. Brewer, with the remark : "This, it is now generally conceded, has no claim to be placed in the avi-fauna of New England. Except as accidental in Greenland, it is not even North American " (Pr. Bost. Soc., xvii, I875, p. 453). But this statement is too sweeping. Dr. Brewer himself has the pleasure of correcting it, in recording the capture of a specimen on the Georges fishing banks, off the Massachusetts coast, in July, I 878 (Bull. Nutt. Club, iii, I 878 , p. I 88). This specimen was brought into Gloucester, and examined by Prof. Baird. 


\section{POMARINE JAEGER.}

\section{Stercorarius pomatorhinus (Temm.) Lawr.}

Chars. Bill and tarsi relatively longer than in the foregoing; central rectrices finally projecting far beyond the rest. Smaller and less robust. Middle tail-feathers finally projecting about four inches, broad to the tip. Length about 20.00; wing, 14.00; bill, I.50-I.75; tarsus about 2.00. Adult: back, wings, tail, crissum and lower belly blackish-brown, deepening on the top of the head and slight occipital crest to brownish-black; below, from bill to belly, and neck all round, pure white, excepting acuminate feathers of sides of neck, which are pale yellow ; quills whitish basally; their shafts largely white; tarsi above blue, below, with the toes and webs, black. Not quite adult: as before, but breast with dark spots, sides of the body with dark bars, blackish of lower belly interrupted; feet black. Younger : whole under parts, with upper wing and tail-coverts, variously marked with white and dark; feet blotched with yellow. Young: whole plumage transversely barred with dark brown and rufous; feet mostly yellow. Dusky stage (coming next after the barred plumage just given ?): fulıginous, unicolor; blackish-brown all over, quite black on the head, rather sooty-brown on the belly; sides of the neck slightly gilded.

Of rare occurrence along the coast in autumn and winter; Merriam could give no Connecticut instance. The bird is known to have been taken in Pennsylvania; according to Mr. Boardman it is not uncommon at Grand Menan.

\section{PARASITIC, OR RICHARDSON'S JAEGER.}

Stercorarius parasiticus (B̈rimn.) Gray.

Chars. Middle tail-feathers finally projecting about four inches, tapering, acuminate ; smaller; wing, I2.00-1 3.00 ; tarsus, $1.75-$ 
I. 87 ; bill, 1.33-1.50 ; tail. 5.00-6.00, the long feathers up to 9.00 . Adult: upper parts, including top of the head and slight occipital crest, and crissum, blackish-brown, deeper on wings and tail ; chin, throat, sides of head, neck all round and under parts to the vent, white, the sides of the neck pale yellow; quills and tail-feathers with whitish shafts; feet blue and black. Younger: clouded below with dusky in variable pattern and amount. Young: barred crosswise with rufous and dusky; feet mostly yellow. There is a fuliginous stage, precisely as in the last species.

The commonest of the Jaegers, yet not one of the abundant sea-birds of our coast. Linsley has it from Bridgeport, Conn., and Merriam cites another instance of its occurrence in this State, a specimen in the collection of Mr. J. H. Sage, of Portland, having been killed at that place in the fall of 1875 (Rev. B. Conn., I 877, p. I 3 I).

\section{LONG-TAILED, OR ARCTIC JAEGER.}

\section{Stercorarius buffoni (Boic) Coucs.}

Chars. Middle tail-feathers finally projecting eight to ten inches, very slender and almost filamentous in the greater part of their extent. In size smaller than the foregoing; wing about 12.00 ; tail about 6.00 ; tarsus, I.50-1.70; bill. I.00-1.12. Coloration as in $S$. parasiticus, and changes of plumage the same.

Occurring off the coast in fall and winter, with other species of the genus. A fresh case of its presence on our southern border is given by Merriam, - a specimen taken on the Community Lake, at Wallingford, Conn., August 30, I873 (Rev. B. Conn., I877, p. I 3 I). 


\section{GLAUCOUS GULL, OR BURGOMASTER.}

\section{Larus glaucus Brïnn.}

Chars. Adult: general plumage white; primaries entirely white, or very pale pearly-blue, fading insensibly into white at some distances from the ends, their shafts straw-yellow. Mantle palest pearly-blue. Bill yellow with red spot on lower mandible; feet flesh-colored or pearl-yellowish. In winter: head and hind neck lightly touched with gray. Young: impure white, with or without traces of pearly-blue on the mantle; head, neck, and upper parts mottled with pale brownish, sometimes quite dusky on the back, and under parts a nearly uniform but very faint shade of the same; quills and tail often imperfectly barred with the same; bill flesh-colored or yellowish, with black tip. Very large; length about 30.00 ; extent, 60.00; wing, 18.00I8.50; bill, 2.75-3.00; tarsi about 3.00.

This magnificent Gull is the most boreal representative of the genus, uncommon even in Labrador, and very rare in New England, where it only occurs in winter. It has been taken on Long Island, and in New York State, but does not appear to have ever been observed in Connecticut. Mr. H. Herrick gives it as a winter resident at Grand Menan, and the name occurs in nearly all the New England Lists, citation of which, however, does not appear to be required.

\section{WHITE-WINGED GULL.}

\section{LARUS LEUCOPTERUS Faber.}

Chars. Coloration precisely as in L.glaucus; size less; length, 24.00 (rather less than more); wing, 16.00-17.00; bill, 1.75-2.00; tarsus, $2.00-2.25$. 
Another species occurring off the coast in winter, but apparently one of the rarer gulls. It may, however, be really more common than is supposed, as it closely resembles the ordinary Herring Gull in size and general appearance, excepting the black tips of the wings, and is therefore liable to be overlooked.

\section{GREAT BLACK-BACKED GULL.}

\section{LARUS MARINUS $L$.}

Chars. General plumage white, primaries crossed with black; feet flesh-colored; bill yellow with red spot. Mantle blackish slatecolor ; first primary with the end white for two or three inches ; second primary with a white subapical spot, and, like the remaining ones that are crossed with black, having the tip white (when not quite mature, the first with small white tip and subapical spot, the second with white tip alone). In winter, head and neck streaked with dusky. Young: whitish, variously washed, mottled and patched with brown or dusky; quills and tail black, with or without white tips; bill black. Very large; equalling or even exceeding $L$. glaucus.

Unlike the preceding, this is a common winter resident along the coast, and some individuals breed in Maine. The great birds may be seen now and then sailing over our harbors in company with Herring and Ring-billed Gulls, from which they are readily distinguished by their superior size, even should they be in the dark plumage of the young birds, as is most frequently the case, or if the slaty mantle of the adults be not visible in flight. They are more numerous on the open coast than in the harbors. 


\section{HERRING GULL; COMMON GULL.}

\section{LARUS ARgEntatus smithsonianus Cones.}

Chars. Adult: general plumage white. Feet flesh-color; bill yellow with red spot; mantle dull blue (darker than in glaucus, but nothing like the deep slate of marinus - much the same as in all the rest of the species); primaries marked as in marinus, (but the great majority of specimens will be found to have the not quite mature or final condition). Length, 22.00-27.00; wing, I 5.00-18.00 ; tarsus, 2.25-1.75; bill about 2.25 long, about $0.67-$ 0.75 deep at base, and about the same at the protuberance. In winter: head and hind neck streaked with dusky. Young: at first almost entirely fuscous or sooty-brown, the feathers of the back and wings with paler edges; bill black; quills and tail black, white-tipped or not; size at the minimum above given. As it grows old, it gradnally lightens; the head, neck and under parts are usually quite whitish, before the markings of the quills are apparent, and before the blue begins to show, as it does in patches, mixed with brown; the black on the tail narrows to a bar, at the time the primaries are assuming their characters, but this bar disappears before the primaries gain their perfect pattern. At one time the bill is flesh-colored or yellowish, black-tipped. The American bird proves to average larger than the European in all its parts, as observed in several other waterbirds; whence $L$. smitisonianus Coues.

This is the commonest New England Gull, neither confined to the coast, nor occurring only in winter, though more frequently under these than any other circumstances. It appears to have formerly bred along the coast from Massachusetts northward, and individuals are still to be seen now and then during the whole year; but its breeding seems to be now chiefly if not entirely confined to eastern localities in Maine. Farther east and north it is extremely common in summer, as in 
Nova Scotia, Newfoundland and Labrador. The nest is usually placed on the ground, sometimes on rocks or even trees, being a considerable heap of grasses, mosses, or seaweeds; the eggs are normally three in number, about $2.75 \times 1.90$; the ground color, an extremely variable shade of greenish-gray, or drab, sometimes darker olive, dotted, spotted and blotched in the most irregular manner with dark brown and neutral tints. The Herring Gull is a constant feature of the scene in our harbors from September till April, sailing with great buoyancy overhead, eagerly scanning the surface of the water in search of food. The majority of such birds are in the dark or mottled plumage of the first and second years.

\section{RING-BILLED GULL.}

\section{LARUS DELAWARENSIS Ord.}

Chars. Adult plumage precisely like that of the last species, and its changes substantially the same ; bill greenish-yellow, encircled with a black band near the end, usually complete, sometimes defective, the tip and most of the cutting edges of the bill yellow; in high condition, the angle of the mouth and a small spot beside the black, red; feet olivaceous, obscured with dusky or bluish, and partly yellow; the webs bright chrome. (Observe the coloration of the feet, as compared with argentatus. Notably smaller than argentatus; length usually 18.00-20.00; extent about 48.00 ; wing about I 5.00 ; bill under 2.00 , and only about 0.50 deep at the protuberance; tarsus about 2.00; obviously longer than the middle toe.

Another common winter Gull, oftener seen in dark mottled plumage than with snow-white under parts and 
pearly mantle, circling over the harbors. It can scarcely be distinguished from the last under these circumstances, but is constantly smaller. It is not confined to the coast, being one of the species most frequently seen on the larger inland waters. Its known breeding-range is such that the bird will doubtless be found sometimes nesting in New England, though we have at present no record to that effect. Mr. Boardman speaks of its presence in Maine in summer.

\section{KITTIWAKE GULL。}

\section{Rissa tridactyla $(L) B$.$p .$}

Chars. Hind toe only appearing as a minute knob, its claw abortive. Mantle rather dark gravish-blue; first primary with the whole outer web, and the entire end for about two inches, black; next one, with the end black about as far, but outer web elsewhere light, and a white speck at extreme tip; on the rest of the primaries that have black this color decreases in extent proportionally to the shortening of the quills, so that the base of the black on all is in the same line when the wings are closed (a pattern peculiar to the species of Rissa): and these all have white apex. Bill yellow, usually clouded with olivaceous. Rather small. Length, 16.00-18.00; wing, 12.00; bill, 1.33-1.50; tarsus about the same; middle toe and claw longer. Tail usually slightly emarginate. In winter, nape and hind neck shaded with the color of the mantle. Young: bill black; a black bar on the tail, another across the neck behind; wings and back variously patched with black; dark spots before and behind the eyes; quills mostly black.

On the coast in winter, and common. This is one of the most abundant of the Larida breeding in the Gulf of St. Lawrence, as at the Magdalen Islands with 
the Gannets, as well as along the Labrador coast; and a few also breed on the coast of Maine and in the Bay of Fundy.

\section{BLACK-HEADED OR LAUGHING GULL.}

\section{Chroïcocephalus atricilla (L.) Lazur}

Chars. A species of medium size, of less robust form and slenderer bill than most of the foregoing. In the breeding season the white of the under parts rosy-tinted, and the head enveloped in a dark-colored hood. Length, I6.00-19.00; wing, 12.00-13.00; tarsus, 2.00 ; middle toe and claw, 1.50; bill, about 1.75, the tip elongated and decurved, so that the point comes nearly or quite

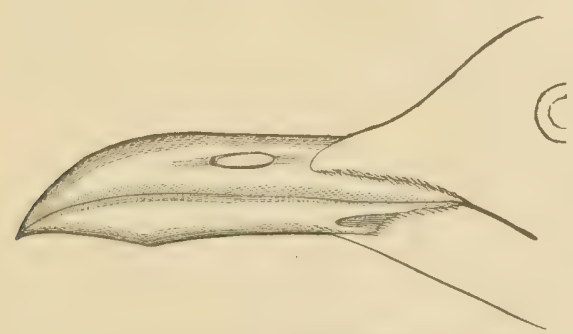

Fig. 76. - Bill of Laughing Gull, nat. Size.

down to the level of the small acute prominence of the gonys. Mantle grayish-plumbeous; hood dark plumbeous; eyelids white; black on primaries taking in nearly all the first quill, but rapidly decreasing to the sixth; the white tips very small, few, or wanting; bill and feet dusky carmine. In winter, not rosy, and unhooded; head white, with dusky or grayish patches on the nape and auriculars. Young: quite brown, paler, grayish or whitish below and on the upper tail-coverts; feathers of the back dark with paler edges; quills and tail black, or latter white or partly grayish-blue, with a black bar; bill and feet dusky or browrish.

Unlike all the foregoing, the present is a southern species, and a summer resident only with us. It ap- 
pears to have formerly been more common than it is now, and Mr. Allen speaks of its being nearly extirpated in Massachusetts. It usually arrives in April, and remains until September, sometimes into October. The nest is placed upon the ground, usually the sand of the seashore; the eggs are two or three in number, usually three, measuring from 2.00 to 2.25 in length by about 1.60 in breadth; in coloration they are not distinguishable from those of other Gulls. The bird breeds only very sparingly north of Massachusetts.

\section{BONAPARTE'S GULL.}

\section{Chrö̈cocephalus philadelphia (Ord) Lazr.}

Chars. Tarsus about equal to middle toe and claw. Small. Length, I 2.00-I 4.00; wing, 9.50-10 50; tarsus, I.33; bill, I.12-I.25, very slender, like a Tern's. Adult in summer: bill black; mantle pearly blue, much paler than in the foregoing; hood slaty-plumbeous, with white touches on the eyelids; many wing-coverts white; feet chrome yellow tinged with coral red; webs vermilion. Primaries finally, - the first five or six with the shafts white except at tip; first, white, with outer web and extreme tip black; second, white, more broadly crossed with black; third to sixth or eighth, with the black successively decreasing. In winter, no hood, but a dark auricular spot. Young: mottled and patched above with brown or gray, and usually a dusky bar on the wing; the tail with a black bar, the primaries with more black, the bill dusky, much of the lower mandible flesh-colored or yellowish, as are the feet.

Bonaparte's Gull is one of the smallest and airiest species of the Larida, closely resembling a sea-swallow both in habits and in general appearance. It is very 
common in New England, but the circumstances of its presence can hardly be stated without qualification. There is probably no month in the year when the bird may not be found with us, unless it be in the depth of winter. It is commonly seen late in the summer, and its numbers increase in the fall. It resides all the summer in Maine, yet we have no authentic record of its breeding there. It would appear to belong most properly to the category of spring and fall migrants, its presence in summer being chiefly during the latter part of that season, as in the cases of various Sandpipers, which, like this Gull, have a high north breeding range. Individuals are commonly seen into the winter months, and great numbers appear from the south in April. During the migrations the pretty birds fairly swarm by thousands.

\section{FORK-TAILED GULL.}

\section{Xema sabinil (Sab.) Leach.}

Chars. Adult: white, including inner primaries, most of secondaries, and greater coverts; head enveloped in a slate-colored hood, succeeded by a velvety-black collar; mantle slaty-blue, extending quite to the tips of the tertiaries; whole edge of the wing, and first five primaries, black, their extreme tips, and the outer half of their inner webs to near the end, white; bill black tipped with yellow; feet black. Length, I3.00-14.00; wing, 10.00I1.00; bill, 1.00; tarsus, 1.25; tail, 5.00, forked an inch or more. The changes of plumage are correspondent with those of $C$. philadelphia. In the young the tail is simply emarginate.

This very elegant little Gull is probably not so rare as is commonly supposed. For many years it remained one of the least known of the North American repre- 
sentatives of the Larida, being only less rare in collections than Rhodostethia rosea and Xcma furcata; but of late it has been turning up anywhere, and the probability is that it has been often overlooked or confounded with Bonaparte's Gull, which it resembles closely. Although recorded many years ago by $\mathrm{Mr}$. Lawrence for Long Island, it does not appear to have been recognized as a New England bird until noted as such by Mr. William Brewster in the "American Sportsman" (v, I 875 , p. 370), then published at West Meriden, Conn., by the late Mr. William F. Parker, one of the firm manufacturing the well-known "Parker gun." This is the case of a specimen taken in Boston Harbor, Sept. 27, 1864, by Mr. H. W. Diamond, and later placed in Mr. Brewster's collection. (See also Bull. Nutt. Club, i, $1 S 76$, p. 30, and Pr. Bost. Soc., xvii, I 875 , p. 449: same case.) In I 878 , Mr. Allen recorded a specimen taken in the spring of that year at Calais, Maine, by Mr. Boardman, in nearly full plumage (Bull. Nutt. Club, iii, I878, p. 195). The same note by Mr. Allen also speaks of a third case of which he was informed, - that of a specimen taken a short time before at Portland, Maine. Concerning the Calais case, Mr. Boardman writes to Dr. Brewer: "I have known this bird to be about almost every spring; but was never able to get one, and only succeeded by getting a cartload, almost, of Bonaparte Gulls. As you go from Eastport to Calais, you can often see with a good glass a Gull or two, among the thousands with the black wingfeathers, different from the Bonapartes" (Pr. Bost. Soc. Nat. Hist., $\mathrm{xx}, 1879$, p. 285). 


\section{GULL-BILLED OR MARSH TERN.}

\section{Sterna anglica Mont.}

Chars. Bill remarkably short, stout, and obtuse, hardly or not half as long again as the tarsus; bill and feet black; pileum black; mantle pearly grayish-blue, this color extending on the rump and tail ; primaries with the white stripe restricted to their bases, their shafts white. Length, I3.00-15.00; extent, about 34.00; wing, I0.00-12.00; tail, 4.00 , forked only 2.00 or less, the lateral feathers little narrowed; tarsi, 1.00-1.25; bill, I 33 .

Of casual and rare occurrence. The only instances which have come to our knowledge are those given by Mr. Brewster, of a specimen taken at Ipswich, Mass., in September, I87I (Am. Nat., vi, I872, p. 306), and one shot at Grand Menan in the latter part of August, 1879, as noted by Mr. Deane (Bull. Nutt. Club, v, I880, p. 63). But the species is given by nearly all the earlier writers, upon data which were doubtless satisfactory to them at the time. It breeds plentifully as far north as Cobb's Island, $\mathrm{Va}$.

\section{CASPIAN TERN.}

\section{Sterna caspia Pall.}

Chars. Of great size, being much the largest of the Terns. Occiput slightly crested. Feet black, bill red. Mantle pearly grayishblue; black cap extending below the eyes, but under eyelid white; primaries without any white stripe. In winter, black of the cap mostly restricted to the occiput. Young with bill dusky and yellowish; back, wings and tail patched with brown or blackish. Length, 20.00 or more; wing, 15.00-17.00; tail, 5.006.00 , moderately forked, without narrowed feathers; bill, 2.332.75 , very stout, 0.75 or more deep at base, 0.50 wide opposite nostrils; tarsus, I.67-I.75; middle toe and claw rather less. 
Of regular and not uncommon occurrence. This great Tern - as large as an average Gull - has commonly been considered both as a northern species and as rare in North America. But it is neither, for it is known to breed off the Virginia coast, and abundantly in Texas; and it has also occurred in the interior of the United States, as well as along the coast. Probably no year passes without its presence in New England. Allen notes it for Massachusetts as rare or occasional in winter (Bull. Essex Inst., x, I878, p. 29). Brewer notes it as "occasional" for Massachusetts, and queries it for Maine (Pr. Bost. Soc., xvii, r875, p. 449). But Mr. Brewster is more explicit: "The Caspian Tern - all previous statements to the contrary notwithstanding - must be regarded a regular visitor every season, and one by no means uncommon. They come down from their northern breeding grounds during the latter part of September, and for several weeks, at least, are to be found in moderate numbers all along our seaboard. I have observed them at various points from Ipswich to Nantucket. At the latter place, upon one occasion, six individuals were seen fishing in the harbor near the town. As to their wintering within New England limits, I can offer only negative evidence, but that points to the inference that they pass further south with the approach of severe weather. During the first week of May, I875, I found them quite numerous at Chatham, Mass. They frequented the sandbars near the shore, and kept apart from the Herring and Black-backed Gulls, the only other species of Larida present at the time" (Bull. Nutt. Club, iv, I879, p. I4). Mr. Purdie informs us that he possesses a young specimen taken in Boston Harbor. A July 
occurrence in Westerly, R. I., is noted in Orn. and Oöl., vi, I88 I, p. 44.

\section{ROYAL TERN; CAYENNE TERN.}

\section{Sterna maxima Bodd.}

Chars. Scarcely less in linear dimensions than the Caspian Tern, owing to greater length of tail, but much less bulky. Length, I8.00-20.00; wing, 14.00-15.00; tail, 6.00-8.00, deeply forked, with narrow lateral feathers; tarsus, about 1.25 ; middle toe, I.25 or more; bill, 2.50-2.75, 0.50-0.67 deep at base; gonys, about 1.00 long. Bill orange ; feet black ; occiput lightly crested; cap black, but often, even in summer breeding birds, the black chiefly restricted to the lengthened feathers of the hind head; mantle pale grayish-blue; quills silvered-dusky with long white stripe.

This is only a straggler from the south, of casual occurrence. Messrs. C. J. Maynard and Wm. Brewster made captives of a male and female at Nantucket Island, July I, I874. "The female bore marks of having just laid. Both specimens were in somewhat peculiar plumage" (Am. Sports, v, Jan. 16, I875, p. 249). While at Penikese Island, I had brought to my notice a specimen seen there about the same time.

\section{SANDWICH TERN.}

\section{Sterna cantiaca $G m$.}

Chars. Bill black, tipped with yellow; plumage as in the foregoing, but mantle extremely pale. Length, 15.00-16.00; wing, about 12.00 ; tail, 5.00-6.00; bill, 2.00-2.30, the yellow end from 
0.75 of an inch to a mere point; tarsus, 1.00 ; middle toe and claw, 1.12 .

Another of the stragglers which occasionally visit us from southern waters. It was included among our birds by Coures in 1868 , as of undoubted occurrence on the coast. As Dr. Brewer remarks, "the capture of two specimens by Mr. Vickary at Chatham, Cape Cod," in August, I865, first gave it a right to take its place

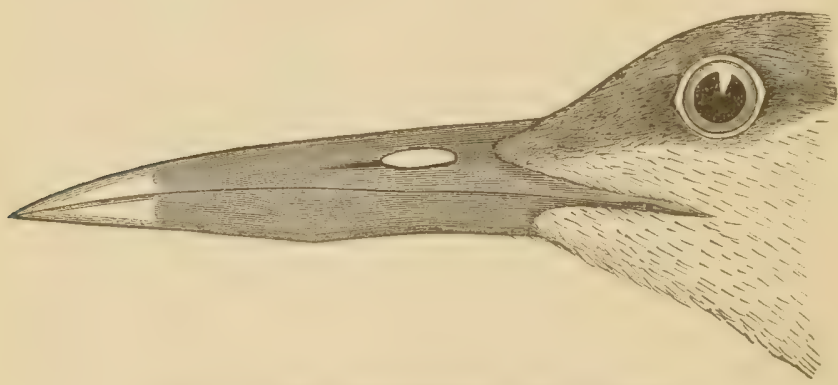

Fig. 77.-Bill of SANDwich Tern. Nat. size.

among the rare and accidental birds that visit our coast (Pr. Bost. Soc., xvii, I 875, p. 449). This Chatham record was made by Allen (Am. Nat., iii, 1870, p. 644).

\section{COMMON TERN; WILSON'S TERN; SEA SWALLOW.}

\section{Sterna hirundo Auct.}

Chars. Bill red, blackening on the terminal third, the very point usually light; feet coral-red. Mantle pearly grayish-blue; primary shafts white, except at the end; below white, washed with pale pearly plumbeous, blanching on throat and lower belly; cap 
black; quills silver dusky with long white stripe; tail mostly white, the outer web of the outer feather clarker than the inner web of the same. Length of male, I3.00-16.00; extent, 29.0032.00; wing, 9.75-11.75; tail, 5.00-7.00; tarsus, 3.66-3.87; bill, I.25-1.50; whole foot averaging I.75. Female rather less, averaging toward these minima. Young birds may show a little smaller, in length of tail particularly, and so of total length: length, 12+; wing, 9+; tail, 4+; bill, I.r2+. In winter, this species does not appear to lose the black cap, contrary to a nearly universal rule. Young: bill mostly dusky, but much of the under mandible yellowish; feet simply yellowish ; cap more or less defective; back and wings patched and barred with gray and light brown, the bluish showing imperfectly if at all, but this color shading much of the tail; usually a blackish bar along the lesser coverts, and several tail-feathers dusky on the outer web; below, pure white, or with very little plumbeous shade.

This is one of the four species of Terns which breed abundantly on the coast of New England, no others of our thirteen species being known to pass the summer season with us. It is on the whole the most numerous of all; and as its habits are the same as those of several of its allies, with which it associates during the period of incubation, one description will answer for all. In preference to penning a new account, we select for the pleasure of our readers the charming narrative given by Mr. William Brewster (Bull. Nutt. Club, iv, I 879 , p. I6). During the latter part of May, "a few days after the advent of the 'Little Strikers,' as the Least Terns are called by the 'longshoremen of Virginia, the Wilson's and Roseate Terns begin to appear. They are already paired, but, judging by the occasional bickerings and jealousies that arise, even the more sedate females are not above a little harmless flirtation. It is a pretty sight to see the mated birds sitting side by side upon some long sand-spit, all with their breasts turned to the 
soft morning breeze, and each little glossy black cap glistening in the sunlight. Forty or fifty there may be altogether, with others continually arriving from the distant fishing-grounds. As the incoming birds settle among their fellows, a low murmur of welcome runs through the assembled throng, and fifty pairs of wings are simultaneously raised above their owners' backs. It is like the greeting offered by men to one whom they delight to honor, save that among these simple seabirds even the humblest are rarely neglected. Those individuals occupying the higher portion of the bar are squatted on the warm sand, or lying with wings partially extended to the grateful rays of the sun, while along the water's edge many are washing and pluming themselves, scattering the salt spray in every direction, or toying with the lapping waves. As the rising tide encroaches on their domain, numbers of the more careless are floated off their feet, when they take wing and alight again among the rest. In this way the area continually narrows, until the birds are massed in a compact body upon the highest point. When this at length becomes submerged, they all take wing and remove to some other spot. The same bar is apt to be resorted to daily, and if sufficiently elevated to be beyond the reach of the tides, it is all the more likely to be chosen.

"About the middle of June - the time varying somewhat with different localities - the Terns repair to their breeding-grounds and begin to deposit their eggs. Muskegat, the outermost of a group of low, sandy islands that with Nantucket form the breakwater of the Vineyard Sound, is, and has been since time immemorial, the largest breeding station of the Terns on the New England coast. It is crescentic in shape, three miles 
long by one across at the broadest part, and uninhabited. The beach along the eastern shore is steep and bold, and in the calmest summer weather the heavy surges from the open ocean break upon the shifting sands with an incessant sullen roar. Upon the Sound side shallows and sand-bars extend for miles in every direction, and it is said that at low tide one may wade across to Tuckernuck, more than a mile distant. The interior of the island rises in rolling sand-hills, which are sparsely clothed with beach-grass and a stunted growth of poison ivy, while a few scattered clumps of bayberry-bushes afford the nearest approach to arboreal vegetation. Were it not for man, - who, alas! must be ranked as the greatest of all destroyers, - the Terns would here find an asylum sufficiently secure from all foes. But season after season the poor birds are daily robbed of their eggs by the fishermen, while frequent yachtingparties invade their stronghold and shoot them by hundreds, either in wanton sport or for their wings, which are presented to fair companions. Then the graceful vessel spreads her snowy sails and glides blithely away through the summer seas. All is gayety and merriment on board, but among the barren sand-hills, fast fading in the distance, many a poor bird is seeking its missing mate; many a downy little orphan is crying for the food its dead mother can no longer supply; many a pretty speckled egg lies cold and deserted. Buzzing flies settle upon the bloody bodies, and the tender young pine away and die. A graceful pearl-tinted wing surmounts a jaunty hat for a brief season, and then is cast aside, and Muskegat lies forgotten, with the bones of the mother and her offspring bleaching on the white sand. This is no fancy sketch; all over the world the sad destruction 
goes on. It is indeed the price of blood that is paid for nodding plumes. Science may be, nay, certainly is, cruel at times, but not one tithe of the suffering is caused by her disciples that the votaries of the fickle goddess Fashion yearly sanction.

"My first visit to Muskegat was in I870. It was about the $25^{\text {th }}$ of June when we landed on the island, and three days were spent in investigating its fauna. Although the fishermen told us that the Terns had been diminishing for years, their numbers at that time, nevertheless, were astonishing. The Arctic Terns were breeding apart in a separate colony, on a long, narrow strip of sand, while the Common and Roseate Terns intermingled freely, oftentimes placing their nests side by side. Little preference seemed to be accorded by the last two species to any given locality. Their eggs were as often laid upon the windrows of sea-weed at high-water mark, as among the ivy-vines on the sandhills. Indeed, they were scattered everywhere, and the birds that were breeding there must have been numbered by hundreds of thousands. The sight was a novel and impressive one. Overhead, at varying heights, swarms of Terns were passing and repassing, crossing each other's flight in mazy lines. From the birds just skimming the crests of the sand-hills to the white specks floating thousands of feet above the earth in the blue sky, the air was filled with their countless numbers. Hundreds were continually rising from their nests and making out to sea, or returning from the fishing-grounds, each with a small fish held crossways in its bill.

"If a Tern were shot, the effect was instantaneous and startling. Every voice was at once hushed, hundreds of long narrow wings were set, and troops 
of gliding arrowy forms swept down in silence to the fallen victim. From the sky above, from every nook and corner of the neighboring sand-hills, they came hurrying to the spot. Then, as if at a given signal, every bird burst out afresh in cries of rage, protest and despair. The effect was indescribable. As the graceful birds came whirling down in perfect silence, they seemed like dread avengers seeking to bear away their dead comrade and to overwhelm his destroyer. If another bird were killed, the tumult continued and the excitement became even more intense; but if no further molestation were offered, they gradually departed one by one. This habit of hovering over their slain companions, though undoubtedly prompted by sympathy and social affection, is a most unfortunate one, as it is constantly taken advantage of, and dozens are frequently killed at a time.

"Upon Muskegat the Terns have, or had at the time of which I write, another enemy, which, though second in importance to man, nevertheless destroyed large numbers of these birds. This was the Short-eared Owl (Brachyotus palustris). A small colony of these birds had established itself upon a certain elevated part of the island, spending the day in a tract of densely matted grass. Scattered about in this retreat were the remains of at least a hundred Terns, that they had killed and eaten. Many of these were fresh, while others were in every stage of decomposition, or dried by the sun and wind. In each case the breast had been picked clean, but in no instance was any other portion disturbed. Every day, at a certain time, these Owls sallied forth in search of fresh prey. We used regularly to see them about sunset, sailing in circles over the island or beating 
along the crests of the sand-hills. They were invariably followed by vast mobs of enraged Terns, which dived angrily down over the spot where the Owl had alighted, or strung out in the wake of his flight like the tail of a comet. The Owl commonly paid little attention to this unbidden following, and apparently never tried to seize his persecutors while on the wing, but on several occasions we saw a sitting bird pounced upon and borne off. Sometimes in the middle of the night a great outcry among the Terns told where a tragedy was being enacted.

"I found the Terns sadly diminished in numbers when I last visited Muskegat, in Juiy, I874. Their persecutors were ravishing their stronghold more relentlessly than ever, and nearly every day fishermen came from far and near to collect their eggs. So cleanly had they swept the island that we could find scarcely a nest with eggs, and at that comparatively late date not a single young bird was to be seen. In fact, the poor Terns were kept laying like hens through the whole summer. We were told by the fishermen that quite as many eggs were obtained by them in August as in June. It is doubtful if one pair in a hundred succeeded in raising offspring that year. Under such conditions the result is inevitable. If prompt legislation be not brought to bear on the matter, the time is near at hand when the waters of the Vineyard Sound will no longer be enlivened by these innocent birds. The inconsiderable destruction of small fishes, a reason that has been given for withholding protection, is of little moment, and those barren, sandy shores can ill afford to lose the presence of the graceful Sea-swallow.

"Of the eggs of the three species of Terns which breed 
upon Muskegat, little may be said save that they vary to an almost endless degree, and cannot specifically be distinguished. The Wilson's and Roseate Terns usually build nests, some of which are quite bulky, with a lining of dry grasses, upon a foundation of coarse twigs or seaweed. In many cases, however, the eggs were simply laid in a slight depression in the sand. We fancied that the Roseate Terns built more substantial domiciles than the other species, but the difficulty of satisfactorily identifying any considerable number of nests rendered a positive conclusion hopeless. The Arctic Terns, as before stated, bred apart from the others, and laid their eggs upon the bare sand.

"The notes of the Wilson's and Arctic Terns vary, if at all, only slightly in modulation. The ordinary cry of anger or protest is a harsh vibrating $t \epsilon$-ar-r-r, that of contentment or recognition a soft chick. They utter various other sounds, all more or less discordant. The usual note of the Roseate Tern is a soft, mellow here-it, repeated at frequent intervals. It has, in addition, when excited or angry, a cry which can be closely imitated by forcibly tearing a strong piece of cotton cloth.

"One who has never held in his hand a freshly killed Tern can scarcely imagine its wonderful beauty. The delicate, faultless outlines; the long, slender, graceful wings; the pearly blue-gray back, and soft tinting beneath, set off by the bright coral-red of the feet and bill, all go to make up a whole that must satisfy the most asthetic eye. The delicate blush that suffuses the breast of the Roseate Tern can only be seen in its perfection for a brief period after death, for either it fades altogether, or turns to a dull salmon tint before the 
bird becomes cold. Like an ethereal grace, it shrinks and perishes before the gaze of vulgar eyes.

"When the cares of incubation are over, - and sad, unprofitable cares they must be in most cases for these poor birds, - the Terns resort again to the sand-bars nearest their chosen fishing-grounds. The waters about Nantucket are a favorite haunt, and through the month of September they swarm about every bay and cove that indents the shore. Their movements, however, depend largely upon those of the blue-fish. These voracious creatures prey upon the smaller fishes, and, hunting always in schools, by their combined action drive the feeble fry to the surface, when they are seized by the Terns. The fishermen rely almost wholly upon the actions of the latter to discover the presence of fish in the Sound, and when a flock of Terns is seen hovering over a certain spot, a school of blue-fish is pretty sure to be at work beneath.

"It is an interesting sight to watch the birds collect. A moment before, perhaps only a few were to be seen, leisurely winnowing their way along the shore; but in an incredibly short space of time the lucky discoverer of a school is surrounded by hundreds of his fellows, and a perfect swarm of eager, hungry birds poises over the spot. Dozens dash down at once, cleaving the water like darts, and, rising again into the air, shake the salt spray from their feathers by a single energetic movement, and make ready for a fresh plunge. Every bird among them is screaming his shrillest, and the excitement waxes fast and furious. Beneath, the bluc-fish are making the water boil by their savage rushes, and there is fun and profit for all save the unfortunate prey. Their position is perhaps the best exemplification of 
the "frying-pan and the fire" that can be found in nature.

"The descent of a Tern upon its victim is performed with inimitable ease and grace. The bird frequently disappears entirely beneath the surface, and occasionally even swims a short distance under water before reappearing. The flight of the Roseate Tern is especially dashing and beautiful, with the long cleft tail streaming out behind, or inclining, rudder-like, to either side, as the bird suddenly changes its course. I have seen the Wilson's Tern picking up floating garbage from the surface in the manner of a Gull, but the food is ordinarily small fishes, which are taken alive.

"In clear calm weather in September, few Terns will be seen along shore. They probably wander farther out to sea at such times, or congregate upon the sand-bars to rest and plume themselves. The cleanliness of these birds is remarkable. Not only is the plumage invariably spotless, but I have on more than one occasion seen a wounded one, which had been taken into the boat, begin to arrange its disordered feathers; and its feeble efforts to remove the blood-stains from its fresh wounds were truly touching.

"When the wind blows hard the Terns spend much of their time on the wing, and then display great restlessness and activity. They seem to exult with the freshening breeze, like ships that have been becalmed. At such times I have seen them play for many minutes with a fish which one of their number had captured. The holder would drop it, evidently by design, and the whole troop go sweeping down in pursuit. The foremost was sure to seize it before it reached the water, when it was taken up into the air and again 
dropped. In this manner the prize would be in turn passed from one to another. The game was apparently well understood by all, as no attempt was made by any of them to devour the fish. Swallows will frequently play with a feather in a similar manner.

"The ease with which sea-birds find their way through the densest fog is as astonishing as it is inexplicable. I have seen the Terns passing between the fishing-grounds and Muskegat when it was impossible for human eyes to discern an object many yards away, and yet their course was as direct and decided as in the clearest weather. Indeed, at such times the fishermen are often guided by their flight.

"The Least Terns usually leave for the south in the latter part of August, and the Short-tailed species commonly departs before the close of the succeeding month. But the Wilson's, the Roseate, and the Arctic Terns linger about Nantucket through the first half of October. After that their numbers thin rapidly, and by the $25^{\text {th }}$ all are gone. The fishermen say that they follow the blue-fish in their southward migration. However that may be, when the chilling blasts of early November sweep across the sea, the Herring and Black-backed Gulls have taken their places upon the sand-bars about Nantucket; the Eider Duck, the Scoter, the Whistler, and the Sheldrake flock to fish among the Muskegat 'tide-rips'; and troops of Snow-Buntings whirl over the bleak sand-hills." 


\section{FORSTER'S TERN.}

\section{Sterna fORSTERI Nutt.}

Chars. Like the last; larger, tail longer, and wings shorter. Wing of adult, 950-10.50; tail, 6.50-8.00, thus often beyond the extreme of hirundo, and nearly as in macrura; bill, I.66 (I.50-1.75), and about 0.40 deep at base (in hirundo rarely if ever so deep); whole foot, about 2.00. Little or no plumbeous wash below; inner web of the outer tail-feather darker than the outer web of the same. Young and winter birds may be distinguished from hirundo at gunshot range; the black cap is almost entirely wanting, and in its place is a broad black band on each side of the head through the eye ; several lateral tail-feathers are largely dusky on their inner webs, their outer webs being white.

Though one of the common and generally distributed Terns of North America, Forster's is rare in New England, where it is not known to breed. It is commonly spoken of as only a casual or irregular visitor; but probably no season of migration passes without the presence of the bird along our shores. It is chiefly seen in the fall, during the month of September and in immature plumage. The first definite record for Massachu-

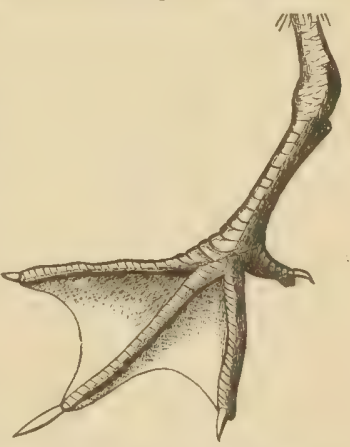

Fig. 78 . - FOOT OF FORSTER's TERN. Nat, size. setts, if not for New England, seems to have been given by Mr. Brewster (Am. Nat., vi, I872, p. 306). Mr. Purdie notes it from the Massachusetts coast (Am. Nat., vii, I 873, p. 693), and Mr. N. T. Lawrence speaks of two Rhode Island specimens (For. and Str., x, I878, p. 235). It has lately been ascertained to breed on the Virginia 
coast (Brewster, Bull. Nutt. Club, vii, 1882, p. 126). Its habits are in all respects the same as those of Wilson's Tern.

\section{ARCTIC TERN.}

\section{Sterna macrura Naum.}

Chars. Bill carmine or lake-red throughout; feet vermilion; plumage like that of hirundo, but much darker below, the plumbeous wash so heavy that these parts are but little if any paler than the mantle; crissum pure white in marked contrast; throat and sides of the neck pale or white. In winter, cap defective; in young, the same. Upper parts patched with gray, brown, or rufous; under parts paler or white; a dark bar on the wing; outer webs of several tail-feathers dusky; bill blackish or duskyred with yellow on the under mandible; feet dull orange. Smaller than hirnndo, but tail much longer. Length, 14.00-17.00; extent, 28.00-30.00; wing, 10.00-12.00; tail, 5.00-8.00; bill, 1.20r.40; tarsus, only $0.50-0.67$; whole foot, about 1.50 .

Like the Common Tern, the Arctic ranges all along the coast, only less numerously than S. limmdo, and in about equal numbers with $S$. dongalli. There is nothing in its habits to distinguish it from its relatives, a full account of which has already been given. It is one of the most elegant species of the family, with lithe form, pearly color, and a sweep of swallow-like tail only rivalled by the Roseate Tern; while none of the family surpasses it in buoyancy and grace of flight. The socalled Portland Tern, S. portlandica, ${ }^{*}$ is simply the young of this species.

* See Ridgway, Am. Nat., viii, 1874, p. 433 ; Coues, Birds Northwest, 1874, p. 691; Brewster, Am. Sportsm., v, Jan. I6, I875, p. 249. 


\section{ROSEATE TERN.}

\section{Sterna dougalli Mont.}

Chars. Bill black, usually orange at base below ; mantle very pale pearly-blue; primaries with the white band broad and usually extending to the very tip. Below, pure white, or rosy-tinted; feet coral-red. Changes of plumage as in other species. Length, 12.00-16.00 ; wing, 9.00-10.00 ; tail, 5.00-8.00; bill, I.33-1.67, very slender; tarsus, $0.75-0.87$.

This most elegant of all our Terns occurs in New England under the circumstances already fully detailed under head of $S$. himundo. The principal point to be noted is, that this is a southerly bird, unknown in the very high latitudes to which Wilson's and the Arctic Tern resort to breed. In fact, it chiefly occurs with us south of Cape Cod, which may be regarded as the normal limit of its extension, though it is known to occur as far north as the Green Islands,

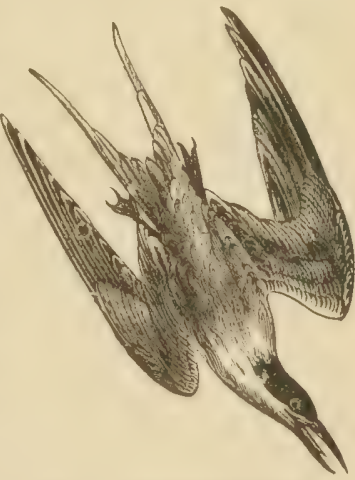

Fig. 79.-ROSEAte TERN. in Casco Bay, Maine, where Mr. Brewster once observed a small flock in July (Bull. Nutt. Club, iv, I879, p. I5).

\section{LEAST TERN.}

\section{Sterna superciliaris antillarum (Less.) Coues.}

Chars. Bill yellow, usually tipped with black; mantle pale pearly grayish-blue, extending unchanged on the rump and tail; a white 
frontal crescent separating the black cap from the bill, bounded below by a black loral stripe reaching the bill; shafts of two or more outer primaries black on the upper surface, white underneath; feet orange. Young: cap too defective to show the crescent; bill dark, much of the under mandible pale; feet obscured. Very small. Length, only 8.00-9.00; wing, 6.00-6.50; tail, 2.003.50; bill, 1.00-1.25; tarsus, 0.67.

The distribution of the Least Tern is nearly coincident with that of the Roseate, being for the most part restricted by Cape Cod in northward extension.

The usual number of eggs of this species is two, not three, and often only one is laid. They do not average over $1.25 \times 1.00$, being therefore decidedly smaller than those of the foregoing three species of Sterna, and difficult to find unless the birds are very numerous, because their color closely assimilates that of their surroundings. The ground color varies from clear pale greenishwhite to pale dull drab or olivaceous. The markings are numerous, and generally distributed, though they frequently tend to wreathe around the large end, especially when they are of large size; they consist of small splashes, irregular spots, and mere dots of clear brown of several shades, together with numerous pale, illdefined lilac or gray shell-markings.

\section{SOOTY TERN.}

\section{Sterna fuliginosa $G m$.}

Chars. No occipital crest; bill and feet black. Above, brownishblack, continuous from head to tail ; under parts, outer web of outer tail-feather, and a frontal crescent, white. Very young birds are fuliginous, speckled with white. Length, 15.00-17.00; wing, 11.00-12.00; tail, 6.00-8.00; bill, 1.50-2.00; tarsus, 0.87 . 
This is another straggler, - one of the four Terns of casual occurrence, among the eleven species known to occur in New England. It was properly given as a bird of our country by Samuels and Coues, not to mention any earlier trace there may be of its presence in this country. (See Allen, Pr. Essex Inst., iv, 1864, p. 90 ; Coues, ibid., v, I868, p. 309 ; Samuels, App. to Orn. and Oöl. of N. E., I867, p. 583 ; Maynard, Nat. Guide, I 870 , p. I 57.) In 1875 it was formally expunged from the list by Dr. Brewer, with the remark: "This is a southern species, unknown on our coast, or that of New Jersey" (Pr. Bost. Soc., xvii, I 875, p. 443); after which, as usual in such cases, the explicit records of its presence began to multiply.

"Mr. Clark informs me that he has this species in his collection, mounted from a bird that last summer flew against the side of the steamboat-wharf depot at Saybrook, Conn. (Purdie, Bull. Nutt. Club, ii, I877, p. 22).

Mr. Ruthven Deane records "the capture of a fine adult male on the Merrimac River, near Lawrence, Mass., on October 29, I876. I examined the specimen at the store of Mr. Charles I. Goodale, taxidermist, who has finely preserved it, and it is now in the possession of Mr. W. A. Howland of Lawrence" (Bull. Nutt. Club, ii, 1877 , p. 27). Mr. Deane also tells us of a specimen, the tenth for New England, "a fine adult male, taken at Newmarket, N. H., about Sept. I4, I878, by Mr. D. C. Wiggin. I am indebted to Mr. Charles I. Goodale, who has preserved the specimen, for the above facts" (ibid., iii, 1878, p. 195).

Mr. Merriam adds to the New England history of this bird the following facts: "A rare visitor from the south. Prof. Sanborn Tenney states that a specimen 
was killed as far inland as the northwest corner of Massachusetts ('near the Hoosac River'), in September, I876 (Am. Nat., xi, I877, p. 243). Mr. Fred. T. Jencks, of Providence, R. I., writes me that he took a particularly beautiful specimen at Point Judith, R. I., last fall. Two adult birds killed themselves last Septembar, by flying against the light-house tower at Falkner's Island. One of them is now in the collection of Capt. O. N. Brooks of that place. Mr. Elbert Coe, of Stony Creek, Conn., has a mounted specimen which was killed there with a stone, late in the summer (1876). Mr. Norman Elmore, of Granby, Conn., has just sent me, for examination, a bird of this species that was taken in that vicinity, Sept. 20, I876. The Rev. J. Howard Hand writes me that it was procured in a singular place and manner. 'It was knocked down with a stick by a gentleman who was netting Wild Pigeons. He first saw it, I think, on the pigeon poles. He got it alive, but of course could not get it to eat, and after keeping it two or three days it died.' This, and the one killed by Elbert Coe, Esq., are both in the youngof-the-year plumage described by Coues. It is a singular fact that all these specimens were killed last fall, and probably all in September" (Rev. B. Conn., I877, p. I34). There was evidently an irruption of the birds into New England that fall. Mr. Allen's summary of these records makes six Connecticut cases, one for Rhode Island, and two for Massachusetts (Bull. Essex Inst., $\mathrm{x}, \mathrm{I} 878, \mathrm{p} .30$ ).

Mr. Deane records a remarkable case, of which he says: "Through the kindness of Mr. Horace R. True, I have recently examined an adult specimen of Sterna fuliginosa, which was captured alive in the town of 
Parkman, Piscataquis Co., Me., some eighty miles from the coast, Oct. 5, I878" (Bull. Nutt. Club, v, I880, p. 64).

See also Dr. Brewer's Chatham, Mass., record (Pr. Bost. Soc., xix, I878, p. 308), and Vermont case (ibid., $\mathrm{xx}, \mathrm{I} 879$, p. 276).

\section{BLACK OR SHORT-TAILED TERN.}

\section{Hydrochelidon lariformis (L.) Coules.}

Chars. Adult in breeding plumage: head, neck, and under parts, uniform jet-black; back, wirgs and tail, plumbeous; primaries unstriped ; crissum pure white ; bill black. In winter, and young birds, the black is mostly replaced by white on the forehead, sides of head and under parts, the crown, occiput and neck behind, with the sides under the wings, being dusky-gray; a dark auricular patch and another before the eye. In a very early stage, the upper parts are varied with dull brown. Small : wing, 8.009.0o, little less than the whole length of the bird; tail, 3.50, simply forked; bill, I.12: tarsus, 0.67; middle toe and claw, I.I2.

A rare but regular migrant in spring and fall. Dr. Brewer (Bull. Nutt. Club, iii, I878, p. I40) mentions the capture, by George H. Mackay, of this bird at Nantucket, Buzzard's Bay, August 8, 1877. The valuable contribution of Mr. William Brewster states that he observed "a large number of individuals" on this same island, and in August, 1878 , and on the 16th of the same month, eight individuals were seen in the harbor near the town, and several were shot and examined (Bull. Nutt. Club, iii, 1878, p. 190). Mr. N. C. Brown tells us that "two young examples of $H$. lariformis were taken in Scarborough (Me.) the last autumn, and 
are probably, with one exception, the first detected within the limits of the State" (Bull. Nutt. Club, iv, I879, .p. I08). Mr. Merriam says: "A rare visitor, occurring chiefly in fall. Though essentially an inland species, it is sometimes found along the coast during migrations. Capt. Brooks took one specimen near Goose Island, Conn., about twelve years ago, - the only one he has ever seen. Mr. George Bird Grinnell informs me that his brother shot a bird of this species late in August, near Milford, Conn." Through Mr. Deane, Mr. G. A. Boardman records three from Grand Menan, and writes, "This Tern seems to be of unusual occurrence on the Maine coast" (Bull. Nutt. Club, v, I880, p. 63). Obviously, then, in view of these records, the Black Tern must take its place as a regular New England bird, though a rare one, and one which is not known to breed with us. Unlike our species of Stema, it is not specially a maritime bird, and its usual breecing places are swamps and sloughs in the interior of North America, especially the Western States and Territories.

\section{BLACK SKIMMER.}

\section{RHYNCHOPS NIGRA $L$.}

Chars. Among the singular bills of birds which frequently excite our wonder, that of the Skimmer is one of the most anomalous. The under mandible is much longer than the upper, compressed like a knife-blade; its end is obtuse; its sides come abruptly together, and are completely soldered; the upper edge is as sharp as the under, and fits a groove in the upper mandible; the jaw-bone, viewed apart, looks like a short-handled pitchfork. The upper mandible is also compressed, but less so, nor is it 
so obtuse at the end; its substance is nearly hollow, with light cancellated structure, much as in a toucan; it is freely movable by means of an elastic hinge at the forehead. Plumage glossy black, the forehead, sides of head and neck, and all under parts, pure white, or rosy-tinted; tail ashy and white; bill red, blacktipped; feet orange. Young: grayish-black or dull brown above, varied with white; bill yellow, dusky-tipped. Length, 16.0020.00 inches; extent, 3.00-4.00 feet; wing, $13.00-15.00$ inches ; tail, 4.00-5.00, forked; under mandible, 3.25-4.50; upper, 2.50-3.00.

"The only record of this species occurring in New England, was given by Linsley in 1843 , in his Catalogue

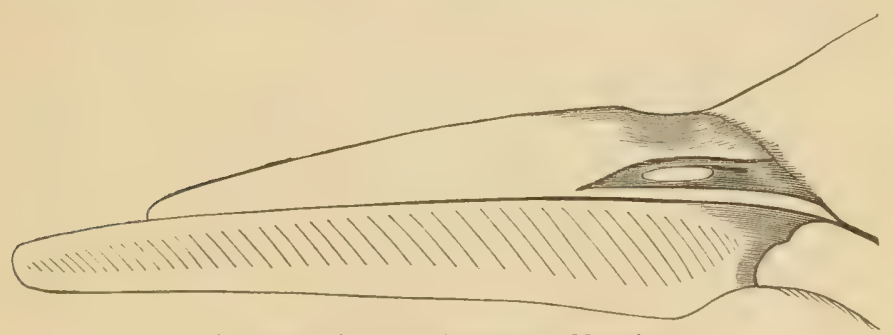

Fig. So. - Bili, of Skimmer. Nat. size.

of the Birds of Connecticut; but since then, writers have considered that it was given without sufficient proof.

"Under date of Aug. 20, I 879, Mr. Charles I. Goodale writes me that three specimens of the Black Skimmer were shot at Sandwich, Cape Cod, Mass., on the I 9 th inst., and that the next day a fourth specimen was killed off Pettock's Island, Boston Harbor, which latter bird he has preserved.

"My friend, Mr. George A. Boardman, of Milltown, St. Stephens, N. B., under date of Aug. 3 I, I 879, writes me that there had been a flight of Skimmers in his locality, and that seven specimens had been killed off 
Grand Menan and Campobello Island, and that they were seen at St. Andrews, at the head of Passamaquoddy Bay. On the same date, while sailing some ten miles from shore off Saco, Maine, I saw a single bird, undoubtedly of this species, flying rapidly along the surface of the water.

"Is it not a little strange that a bird that has escaped our observation for years, should appear so suddenly, and at various points along the coast from Cape Cod to the Bay of Fundy?"

The foregoing is the notice given by Mr. Ruthven Deane in Bull. Nutt. Club, iv, I879, p. 242. But he overlooks Prof. Emmons's record of 1833 , where the bird is marked as a breeder on the Massachusetts coast. Both Linsley and Emmons were probably correct, though the former's record for Connecticut is disallowed by Dr. Merriam.

Dr. Brewer remarks : "Prof. Baird, in a letter dated August 23, informs me that, having occasion to visit Woods' Holl (Falmouth, Mass.), a few days previous, he saw there a young example of Rhynchops nigra, which had been shot at that place on the rgth of that month, by a son of Rev. Dr. Hiram Carleton, an Episcopal minister, resident in the village. This example is to be presented to the New England collection of the Boston Society of Natural History" (Bull. Nutt. Club, iv, I879, p. 243). Dr. Brewer also gives the same case in $\operatorname{Pr}$. Bost. Soc., $\mathrm{xx}, \mathrm{r} 879$, p. 277 . In the same number of the Bulletin, a few pages back (p. 227), I find that Mr. Scott says of it, on Long Beach, N. J., "This is apparently the northern limit of the breeding range of this species, and everywhere they are rather rare. I first saw them on the roth of June, and do not think they 
bred here. But on Brigantine Beach, and at Little Egg Harbor, they are abundant, and breed in numbers."

There was evidently an irruption of Skimmers upon the New England coast in 1879. In addition to the above notices, see also Boardman, Oölogist, v, I879, p. I3, and especially Purdie, Bull. Nutt. Club, vii, i 882, p. 125. Mr. Purdie, in this place, brings up an old record, published over two hundred and fifty years ago in Champlain's Voyages, to the effect that a bird which, from the description, was unquestionably this species, was seen by Champlain while cruising off Cape Cod in July, 1605. Mr. Purdie adds: "That this species was found on our shores early in this century is proved by the older inhabitants of the place telling me that "them cutwater or shearwater birds used to be with us summer times.' Also, Mr. Brewster informs me, that Nantucket fishermen assert that Skimmers bred on Muskegat Island fifty years ago." 


\section{FAMILY PROCELLARIIDE: PETRELS.}

\section{FULMAR PETREL.}

\section{Fulmarus glacialis (L.) Steph.}

Chars. Tail 12-14-feathered; bill straight, very stout, hooked at end, obviously shorter than the tarsus. Adult white, the mantle pale pearly-blue, frequently extending on the neck and tail ; quills blackish-brown; usually a dark spot before the eye ; bill yellow ; feet the same, tinged with greenish. Young: smoky-gray, paler below, the feathers of the back and wings dark-edged; colors of bill and feet obscured. Coloration thus much like one of the Gull family. Length usually about 16.50 , but from I 5.00 to 18.00 ; wing, $12.00-13.00$; tail, 4.00-5.00 ; tarsus about 2.00 ; bill, I.331.67, about 0.75 deep and almost as wide at base; nasal tubes 0.60 .

Leaving now the coasting Gulls and Terns, which seldom venture far from land, we bear straight out to sea, and are already among this interesting family of oceanic birds, so little known to any but those who "go down the sea in ships." Several species of the Procellariide cultivate the "fisherman's farm " of New England ; some of them so plentifully that they are themselves objects of economic value.

The first to be noticed is the Fulmar Petrel, one of the largest of all, but not one of the most numerous. In fact it is usually cited as a rare bird, and certainly no such great gatherings of Fulmars as occur over more northern and some European waters are known to New Englanders. But Fulmars are common enough to have received several names from sailors, who call them "Noddies" and "Marble-headers." Of their breeding 
resorts, if any, within our limits, nothing is known ; the birds being chiefly seen in winter. In other regions they resort by thousands to breed in particular spots, laying a single large white egg in recesses of the rocks. Like many other birds of their family, they may be taken with hook and line, as noted by Dr. Brewer in the following extract: "On Monday, November 4, I878, I saw a living specimen in the yard of Mr. George O. Welch, of Lynn, Mass., to whom it had been sent to be mounted for the Smithsonian Institution. Mr. James W. Milner writes me that this specimen of the Fulmar Petrel was taken by Captain William Sweet, of the fishing schooner Grace C. Hadley, on a codhook, on the eastern part of the George's Bank, which is a very little south of east of Boston, and certainly belongs to the New England coast. It was taken October 28, I878." (Bull. Nutt. Club, iv, I879, p. 64.)

The bird was admitted to our fauna by probably all writers upon the subject, until expunged by Dr. Brewer, shortly before the note above quoted was published (see Pr. Bost. Soc., xvii, I875, p. 453).

\section{STORMY PETREL; MOTHER CAREY'S} CHICKEN.

\section{Procellaria pelagica $L$.}

Chars. Blackish, more fuliginous below, the greater wing-coverts more grayish, the quills, tail, bill, and feet black; upper tailcoverts white, with black tips, and usually some white under the tail and wings; no yellow on the webs; tail a little rounded. Length, 5.75 ; wing, 4.75 ; tail, 2.50 ; bill, 0.50, its height at base 0.20 ; tarsus, 0.90 ; tibiæ bare 0.33 . 
Of the three species of "Carey's Chickens," attributed to our waters, the present one is certainly the rarest, and some have found reason to doubt its occurrence. It is, however, so similar in general appearance to the other two, that it might readily be overlooked; and we are not willing to expunge it from our list only to be at the pains of reinstating it in the future. In point of fact, we have no doubt that it occurs. Both Verrill and Boardman accredit it to Maine; see for example Pr. Essex Inst., iii, p. 160, or Pr. Bost. Soc., ix, I 863 , p. 234.

\section{LEACH'S PETREL.}

\section{Cymochorea leucorrhoa $(V$.$) Cones.$}

Chars. Coloration as in the last species, with conspicuous wh:te upper tail-coverts, but apt to be lighter - rather of a grayish or even ashy tint on some parts. Much larger: length about 8.00 ; wing, 6.00-6.50; tail, 3.00-350, forked; tarsus about 1.00 ; middle toe and claw the same; bill, 0.67 , strong.

Resident off the coast, and the most abundant of the

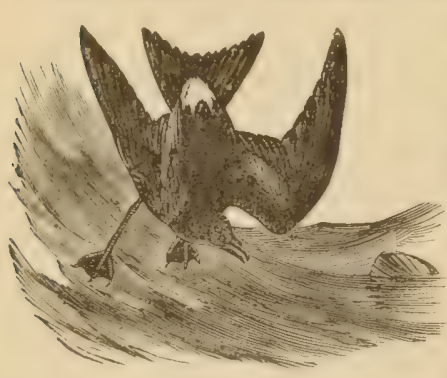

Fig. 8x. - Leach's Petrel. three species. It is known to breed from Maine northward, and may occasionally be seen in summer anywhere else within our limits. Dr. Merriam, in fact, is inclined to believe that a few of this species may breed on the islands off the Connecticut coast. It nests in burrows in the ground, laying a single white egg, often faintly spotted about one end, measuring about I. $30 \times 0.90$. 


\section{WILSON'S PETREL.}

\section{Oceanites oceanicus $(K u h l)$ Coues.}

Chars. Dark sooty-brown, pale gray on the wing-coverts; the upper tail-coverts, and frequently the crissum and sides of rump and base of tail, white; bill and feet black, but webs with a yellow spot. Legs very long; tibiæ bare an inch or more ; tarsi "booted," much longer than the toes; claws flat, obtuse ; bill small and weak; hind toe very minute, liable to be overlooked. Length, 7.00-8.00; wing about 6.00; tail, 3.00, nearly even; tarsus, 1.75; middle toe and claw $1.12 \frac{1}{2}$; bill only . 50.

Common, under the same circumstances as the last, with which it is frequently found in association, though we are not aware that its breeding within our limits is sufficiently attested.

\section{GREATER OR WANDERING SHEARWATER.}

\section{Puffinus major Fabcr.}

Chars. Dark bistre-brown, somewhat plumbeous on the head, most feathers of the back and wings with pale edges, most upper tailcoverts partly white; below, white, with a plain line of demarcation from the color of the upper parts on the side of the head and fore neck, and dark flank-patches; quills and tail blackish, paler or whitish at bases of inner webs; lining of wings mostly white; crissum mostly dark; bill dark; outside of tarsus and outer toe dark, rest of feet pale. Length, 18.00-20.00; extent, 45.00; wing, 13.00; tail, 5.75, outer feathers an inch less; bill, 2.00 ; tarsus, 2.40 ; middle toe and claw, 2.80 .

This is the commonest species of the genus, occurring all along the New England coast. It is well known to the fishermen under the name of "Hagdon," 
or "Hag," and sufficiently numerous to be with them of economic value, being often captured with hook and line, and used for bait. At the same time, nothing is known of its breeding resorts, if any, within our limits. The nesting of birds of this genus resembles that of the Carey Chickens, a single white egg being deposited in burrows under ground or among rocks. The present species is chiefly known with us as a winter bird, and it generally keeps far off shore, as, for example, on Georges Banks, where it is said to be particularly abundant. Dr. Merriam speaks of a specimen stated to have been killed at Granby, Conn. (Rev. B. Conn., I877, p. i36.)

\section{NORTHERN SHEARWATER. (?)}

Puffinus Borealis Cory.

Of this alleged species we have no further information than that given by Mr. Cory, in Bull. Nutt. Club, vi, I88I, p. 84 , where it is described as new from specimens taken off Cape Cod, Mass. The validity of the species would appear to be not yet established; but having seen no specimens, we prefer to reserve further opinion in the case.

\section{MANKS SHEARWATER.}

\section{Puffinus anglorum Temm.}

Chars. Blackish, this color extending below the eyes, leaving the under eyelid white; under parts, including crissum and lining of wings, white; bill greenish-black; outside of foot mostly blackish, inner side dingy orange. Length about I 5.00 ; extent, 
33.00 ; wing, 9.50 ; tail, 4.00 , graduated 0.75 ; bill, 1.33-1.50, but nearly 0.50 deep at base; tarsus under 2.00 ; middle toe and claw, 2.00 , or rather less.

This is a species which has been admitted to our Fauna for many years, but upon authority which, to say the least, requires confirmation. Dr. Brewer claims that no specimen has ever been taken, and is probably right in so doing (see Pr. Bost. Soc. Nat. Hist., xvii, I875, p. 453, and xx, I879, p. 275 ; also Allen, Bull. Essex Inst., $\mathrm{x}, \mathrm{I} 878, \mathrm{p} .35)$. At the same time, we do not feel at liberty to refuse to recognize records which have passed unchallenged for many years, and which we are not prepared to disprove. There is unquestionably, in our opinion, a small New England Shearwater, neither $P$. major nor $P$. fuliginosus, perfectly well known to fishermen, if not to our ornithologists. Capt. J. W. Collins, of the U. S. Fish Commission, a very accurate observer, assures us of this, he himself knowing of three species of "Hags," one of which is the common $P$. major, another is the one all blackish, $P$. fuliginosus, the third being the one in question, like $P$. major, but smaller, darker above, and white below. Mr. R. S. Newcomb, since naturalist of the ill-fated "Jeannette" expedition, also speaks of different kinds of "Hags," among them $P$. anglorum.

\section{SOOTY SHEARWATER.}

\section{Puffinus fuliginosus $A$. Strickl.}

Chars. Dark sooty-brown, blackening on the quills and tail; paler and grayish below, usually with some whitish on the lining of the wings; bill dark; feet dark outside, pale on the inner aspect. 
Length, 18.00 ; extent, 40.00 ; wing, 12.00 ; tail, 4.00 ; bill, 1.752.00 ; tarsus, 2.20-2.33; middle toe and claw, 2.50 .

A species of common occurrence off the coast, usually in company with the $P$. major, from which, however, it

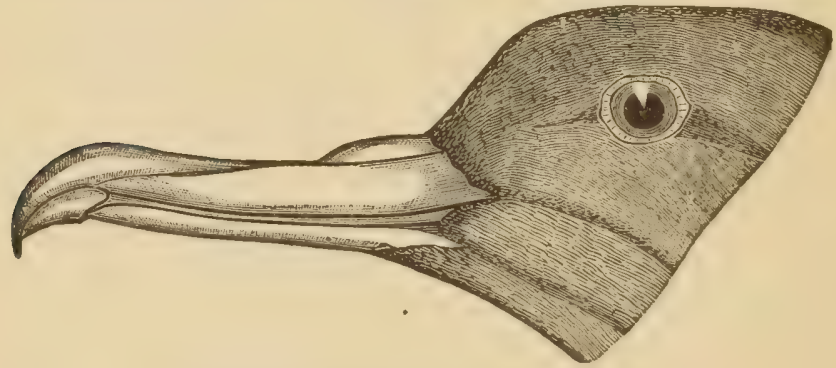

Fig. 8t, - Sooty Shearwater, Nat. size.

is entirely distinct. It is well known to the fishermen as the "Black Hagdon." It appears to be chiefly a winter bird, and its breeding resorts within our limits, if any, are unknown.

\section{PINTADO PETREI.}

\section{Daptium capense (L.) Steph.}

Chars. Upper parts conspicuously spotted with white upon a blackish ground; under parts white; tail black barred; bill black, stout, much hooked. Length, I5.00; wing, Ir.00; tail, 4.50; bill, I.33; tarsus, 1.67 .

As these sheets are passing the press we learn from Mr. Purdie of this most interesting acquisition to our Fauna, which is no less remarkable than that of Astrelata gularis, recently taken in New York (Bull. Nutt. Club, vi, I8S1, p. 9I); both species being birds of the 
Southern Hemisphere. There appears to be no reasonable question in this case. The bird is said to have been shot at Harpswell, Casco Bay, Maine, and is now preserved in the collection of the Natural History Society of Worcester, Mass., where it is or was labelled "Manks Shearwater." The identification of the specimen rests upon Mr. Purdie's authority. I have seen a letter to Mr. Purdie from Mr. E. H. Forbush, of Worcester, containing a statement from a Mr. Wooley, writing from Sabattis, Me., certifying to the capture of the bird at the place named, some eight years ago.

The occurrence of this waif in Maine, and of the other above mentioned in New York, leads us to reflect how little is accurately known of the remarkable family Procellariida. The number of species of these wandering sea-birds which frequent our waters is disputed; and, among those known to do so, the lifehistory of only a single one (Cymochorea leucorrhoa) can be considered to have been thoroughly studied upon our own coast. Extended and reliable observations are required to perfect our knowledge of this subject. 


\section{FAMILY COLYMBIDA : LOONS.}

\section{GREAT NORTHERN DIVER, OR LOON.}

\section{Colymbus tokQuatus Brüm.}

Chars. Black; below from the breast white, with dark touches on the sides and vent; back with numerous square white spots; head and neck iridescent with violet and green, having a patch of sharp white streaks on each side of the neck and another on the throat; bill black. Young: dark gray above, the feathers with paler edges; below, white from the bill, the sicles dusky; bill yellowish-green and dusky. Length, 2.50-3.00 feet; extent about 4.00 ; wing about 14 inches ; tarsus, 3.00 or more ; longest toe and claw, 4.00 or more; bill, 3.00 or less, at base 1.00 deep and 0.50 wide; the culmen, commissure, and gonys all gently curved.

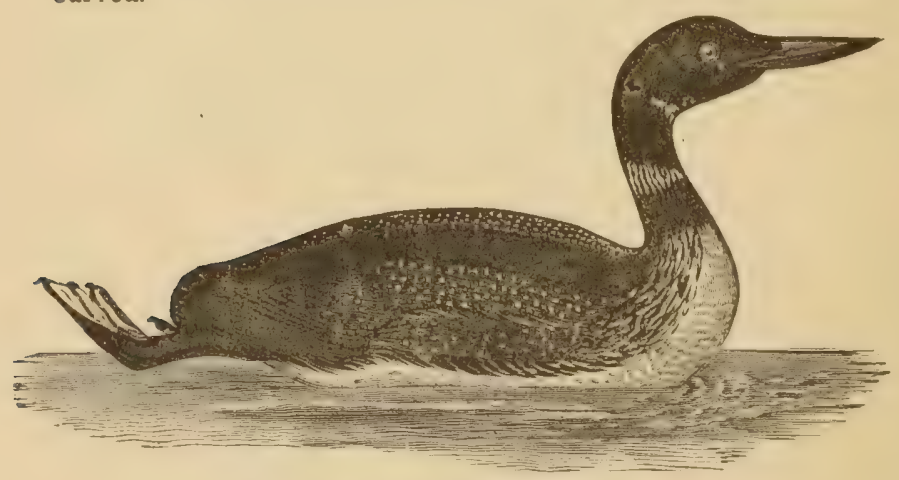

Fig. S2, - Great Northern Diver.

The Loon is properly to be classed as resident in New England, being known to breed occasionally at different points within our limits, and regularly in north- 
erly portions. It is, however, more numerous, or at any rate more conspicuous, in winter than at other seasons, as most individuals of the species breed farther north. It is a common summer bird of Labrador and Newfoundland. The nest is built upon the ground, usually in rank herbage by the water's edge ; the eggs are commonly two in number, measuring about $3.50 \times 2.25$, of a dark greenish or olivaceous color, profusely spotted.

\section{BLACK-THROATED DIVER.}

\section{Colymbus arcticus $L$.}

Chars. Back and under parts much as in the last species; upper part of head, and hind neck, bluish-ash or hoary gray; fore neck purplish-black with a patch of white streaks, the dark color ending abruptly; bill black. The young resemble those of the last species, but will be known by their inferior size. Length, under 2. jo feet; extent about 3.00 ; wing, 13.00 inches or less; tarsus, 3.00 ; bill about 2.50 .

Dr. Brewer doubts the occurrence of this species in New England, though admitting that "its presence is far from improbable. The nearest approach that I can ascertain is one taken near Point Lepreaux, New Brunswick" (Pr. Bost. Soc. Nat. Hist., xvii, 1875, p. 453). But, to all intents, the locality named is New England; and therefore, having no doubt of the impropriety of expunging the bird from the list, we continue to give it that place which has been accorded by nearly all the New England writers, even though we are unable to point to any recent cases of its actual capture within our limits. Coues calls it a "rare winter visitant, not known to 
breed;" Allen marks it as a rare autumn and winter visitant; and Mr. Harold Herrick gives it as of Grand Menan. In a dilemma like this (and there are several such among our water birds) it is useless to deny a moral certainty merely because the circumstantial evidence is not absolutely conclusive, or because we lack a "modern instance."

\section{RED-THROATED DIVER.}

\section{Colymbus septentrionalis $L$.}

Chars. Blackish; below white, dark along the sides and on the vent and crissum ; most of head and fore neck bluish-gray, the throat with a large chestnut patch; hind neck sharply streaked with white on a blackish ground; bill black. Young have not these marks on the head and neck, but a profusion of small, sharp, circular or oval white spots on the back. Size of the last, or rather less.

A common winter visitant along the whole coast. arriving from the north in September or October, and remaining until May. It is most abundant during the migrations in fall and spring, and has even been seen in Southern New England in June; but it is not ascertained to breed within our limits. According to Maynard, it is the most numerous representative of the family during autumn and winter. Mr. Deane speaks of a perfect albino in his possession, which was shot in Salem harbor, Mass. Individuals in perfect plumage, with the red throat, are rare in comparison with the numbers seen in the spotted plumage of the young. 


\section{FAMILY PODICIPEDID $Æ:$ GREBES.}

\section{AMERICAN RED-NECKED GREBE.}

\section{Podicipes griseigena holboelli (Reinh.) Coules.}

Chars. Medium-sized, with moderately long neck; bill not longer than the head, shorter than the tarsus, moderately stout and acute; tarsus about four-fifths the middle toe and claw; crests and ruff moderately developed. Medium : length about 18.00 ; wing, $7.00-8.00$; bill, I. 67 to nearly 2.00 ; tarsus, 2.50 ; middle toe and claw, 2.67. Adult: front and sides of the neck rich brownish-red; throat and sicles of head ashy, whitening where it joins the dark color of the crown; the feathers slightly ruffed; top of head with its slight occipital crests, upper parts generally black or blackish, most feathers with pale edges; primaries brown, but much white on the inner quills; lower parts pale silvery-ash, with dark sides (not pure white, but watered or obscurely mottled, sometimes obviously speckled, with dusky); bill black, more or less yellow at base. The young will be recognized by these last characters, joined with the peculiar dimensions and proportions.

Note. - The Crested Grebe, P.cristatus, was almost universally given by New England writers, until challenged by Dr. Brewer, who questioned its right to be regarded as even a bird of North America. Since then, the species appears to have been dropped by common consent. In view of the improbability that everybody has been mistaken in this case, and of the known general distribution of the species, we incline to the opinion that the species will have to be restored, like probably every one of those expunged by the same authority, though at present we lack the data to convert our opinion into certainty.

The Red-necked Grebe is chiefly a winter bird in New England, though it has occasionally been seen in summer, 
even in Massachusetts, according to Allen. It is not known to breed with us, but the same authority speaks of a specimen in full breeding plumage taken the third week in May in Springfield, Mass.; and Brewer marks the bird as a summer resident in northern New England. Merriam speaks of several Connecticut cases, and the bird is to be regarded as a regular visitant, far from rare, though less numerous than our two smaller representatives of the family.

\section{HORNED GREBE.}

\section{Podicipes cornutus ( $G m$.) Lath.}

Chars. Tarsus about equal to the micldle toe without its claw; bill much shorter than head, little more than half the tarsus, compressed, higher than wide at the nostrils, rather obtuse; crests and ruffs highly developed. Small : length about I4.00; extent, 24,00 ; wing, 6.00 or less ; bill about 0.75 ; tarsus, 1.75 . Adult: above, dark brown, the feathers paler-edged; below, silvery-white. the sides mixed dusky and reddish; most of the secondaries white; fore neck and upper breast, brownish-red; head glossy black, inclucling the ruff; a broad band over the eye, to and including the occipital crests, brownish-yellow; bill black, yellow-tipped. The young differ as in other species, but are always recognizable by the above measurements and proportions of parts.

Chiefly a migrant and winter resident, both along the coast and in the interior, arriving in September and October, and remaining until May-sometimes even through that month. It is given by Brewer as a summer resident in Northern New England, and we have no doubt that this species and the Red-necked Grebe both breed in Maine, although we have no authentic cases of the kind to record. 


\section{PIED-BILLED GREBE, OR DABCHICK.}

Podilymbus podicipes (L.) Lawr.

Chars. Length, I2.00-14.00; wing about 5.00; bill, 1.00 or less, very stout; tarsus, 1.50. Adult: bill bluish, dusky on the ridges, encircled with a black ring; throat with a long black patch; upper parts blackish-brown; primaries ashy-brown, secondaries ashy and white; lower parts silky-white, more or less mottled or obscured with dusky; the lower neck in front, fore breast and sides, washed with rusty. Young: lacking the throat patch and peculiar marks of the bill, otherwise not particularly different; in a very early stage the head curiously striped.

The Dabchick must be classed as a resident in New England. In its range at large, it is a migratory species, but our country falls within the limits both of its summer and winter residence. While it is therefore more numerous and conspicuous during the vernal and autumnal movements, it breeds anywhere with us, and may occasionally be found in winter.

The nest of the Dabchick, like that of other Grebes, consists of a matted mass of broken-down reeds or other aquatic plants, usually sodden and water-soaked, by the edge of the pond, or almost floating on its surface. The eggs are five or six in number, nearly equal-ended, measuring about $1.25 \times 0.87$, with a smooth shell of a whitish color, sometimes as if stained greenish, but not spotted. 


\section{FAMILY ALCIDÆE: AUKS. \\ COMMON PUFFIN: SEA PARROT.}

Fratercula arctica (L.) Steph.

Chars. Not crested; eyelids appendaged; under mandible sulcate, like the upper, the grooves convex forward; culmen simple, with one curve; base of bill bossed; corners of mouth callous. Blackish, including the throat, the sides of the head ashy-gray, with dusky maxillary patches (whole face dusky in the young); below, white ; bill red, blue and yellow ; feet red. A thick blunt excrescence on eyelids. Black of throat not reaching the bill. Length, I3.50; wing, 6.50; tarsus, 1.00 ; bill, 2.00 ; depth at base, $\mathbf{1} .33$.

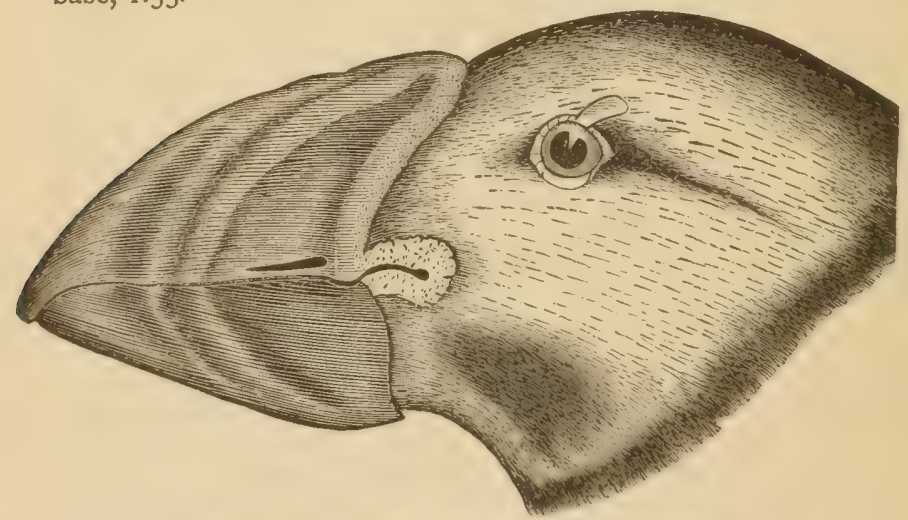

Fig. 83. - Head of Common Puffin. Nat. size.

The distribution and manner of occurrence of this species are nearly coincident with those of the Razorbilled Auk. It is found in winter along the whole coast, and is resident on north-eastern portions, though 
much less numerous than at those favored spots, farther north, where it congregates by thousands to breed, depositing its single egg in burrows underground, or among rocks. The egg is white or whitish, wholecolored or with obsolete spotting, measuring about $2.50 \times 1.75$.

\section{TUFTED PUFFIN.}

Fratercula cirrata Pall.

Chars. Adult: with a long flowing yellow crest of filamentous feathers on each side of the head. Eyelids not appendaged. Under mandible smooth, upper sulcate, the grooves concave forward; basal part of culmen bossed; bill and feet red; claws black; plumage wholly blackish, with white face. Length, I5.00I6.00; wing, $7.50-8.00$; tail, 2.00 ; tarsus, I. 33 ; bill, 2.33 ; nearly 2.00 deep at base.

As is well known, the only authority for the occurrence of this species, which belongs to the North Pacific, is Audubon's statement that one was taken at the mouth of the Kennebec River, in the winter of I83I-'32. Although the case is entirely exceptional, I do not feel at liberty to take it for granted that it is erroneous, and therefore do not follow Dr. Brewer in expunging the species from the list. (See B. of Am., 8 vo ed., vii, p. 234.)

\section{SEA DOVE, OR DOVEKIE.}

\section{Alle nigricans Link.}

Chars. Glossy blue-black, below from the breast (in winter, and in young, from the bill) white; scapulars white-striped; second- 
aries white-tipped; white speck over eye; bill black, short, obtuse, turgid. Length, 8.50 ; wing, 4.75 ; tarsus, 0.80 ; bill, 0.50 ; about 0.37 deep or wide at base.

A species belonging to the high north, only known with us in winter, but of regular and not uncommon

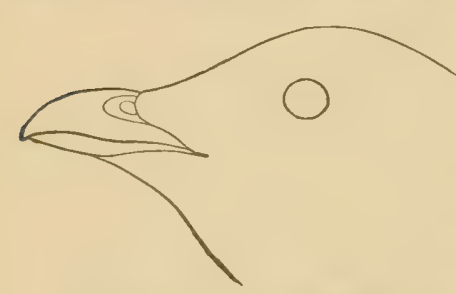

Fig. 84. - SEA Dove. Nat. size. occurrence at that season. It is properly confined to the coast, but several instances are recorded of its having been driven inland by storms, and captured in the most unwonted localities. Various cases of this kind are recorded by Merriam (Rev. B. Conn., I877, p. I38), and by other writers.

\section{BLACK GUILLEMOT, OR SEA PIGEON.}

\section{URIA Grylle (L.) Brïnn.}

Chars. Tarsus reticulate in front; bill with straight commissure, scarcely or not longer than tarsus; outer claw smooth; tail contained less than three times in length of wing. In summer, black, with white on the wings; in winter, largely white; bill black; feet red. Length, 12.00-I 5.00 ; wing, 5.50-6.50 ; tarsus, 1.251.33; bill, 1.33-1.67. A large continuous white area on both upper and under surface of the wing (rarely imperfect or wanting); head and neck with greenish gloss; tail feathers twelve.

Like most other species of the Auk family, this Guillemot occurs along the coast in winter-probably along the whole coast, though Merriam gives no Con- 
necticut case. It also breeds sparingly on islands about the northern limit of the New England coast. The eggs are laid in the crevices of rocks, and are usually two, sometimes three in number, measuring about $2.33 \times 1.55$, of a dull greenish color, variously marked with dark spots.

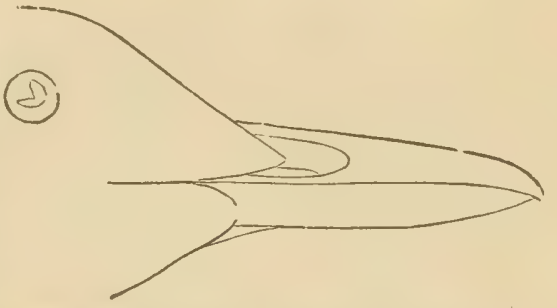

Fig. S5.-Black Guillemot. Nat. size.

\section{COMMON GUILLEMOT, OR MURRE.}

\section{Lomvia troile (L.) Brdt.}

Chars. Tarsi scutellate in front, much shorter than middle toe without claw; bill with decurved commissure, much longer than tarsus; its end, and the outer claw, grooved; nostrils feathered; tail graduated, contained more than three times in the length of wing. Size and coloration almost exactly as described under. Utamania torda, but no white line from bill to eye. Depth of bill at nostrils not nearly half the length of culmen; tomia of upper mandible at base feathered, not noticeably dilated, nor brightly colored. In some cases, edges of eyelids, and line behind eye, white.

Contrary to the general impression, the "common" Guillemot appears to be a rare bird in New England, most of the Murres occurring in winter along our coast being of the following species. Its breeding in some localities on the Maine coast is attested, like that of the 
Black Guillemot, Sea Puffin, and Razor-bill. It is singular that Dr. Brewer should have not only made two

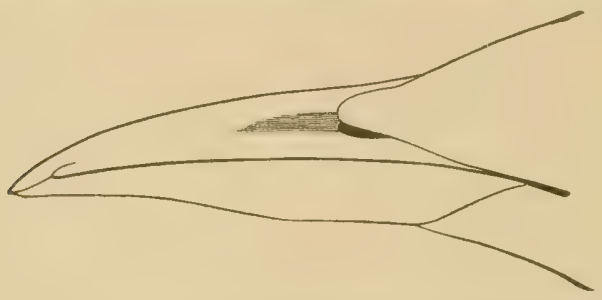

Fig. S6. - Common Guillemot. Nat. size.

species of this single one, but should have assigned them different breeding ranges (Pr. Bost. Soc., xvii, 1875 , p. 450).

\section{THICK-BILLED, OR BRÜNNICH'S GUIL- LEMOT.}

\section{Lomvia ARra (Pall.) Coues.}

Chars. Very similar to the last; depth of bill at nostrils about onehalf the length of culmen; tomia of upper mandible at base dilated, denuded, usually yellowish.

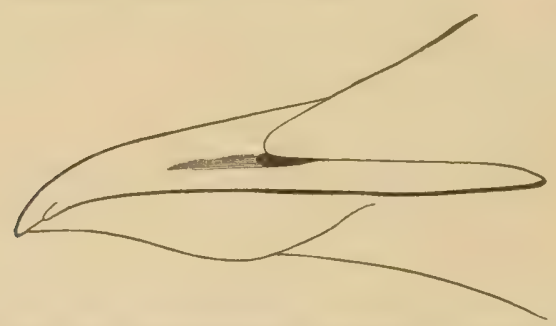

Fig. S7. - Thick-billed Girlemot. Nat, size.

This is the common winter Guillemot of the New England coast, and probably most of the statements supposed to have been based upon L. troile really apply 
to the present species. We have no knowledge of its nesting within our limits.

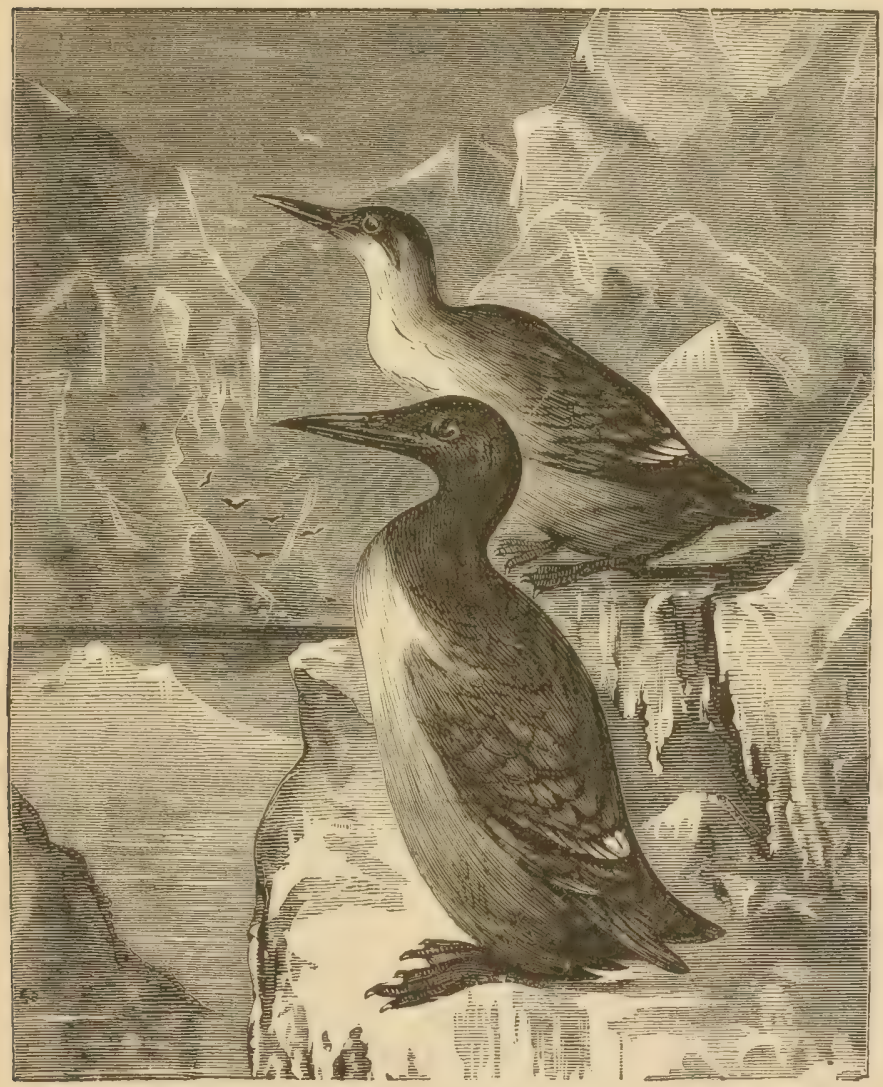

Fig. 88. - Guillemots.

In support of the foregoing statements we may adduce observations lately made by Mr. Harry Merrill, of Bangor, and by Mr. William Brewster. Says the former, speaking of the two species of Murres: "Some idea of 
their comparative numbers may perhaps be obtained from the fact that during the past two years I have procured some thirty specimens from different points on our coast (from Grand Menan to South Bristol), and out of this number only one was a representative of the common Guillemot (L. troile). The experience of Mr. N. A. Eddy of this city is exactly similar, and out of about an equal number of specimens he has obtained but a single example of troile. Other collectors in this vicinity who have received numbers of Guillemots have not obtained a specimen of L. troile." (Bull. Nutt. Club, vii, I882, p. I9I.) Mr Brewster continues the subject: "At different times during the past ten years I have examined specimens from various points along the shores of Maine, New Hampshire, and Massachusetts, and all of the numerous birds that have come under my notice have proved to be Brünich's Guillemots. Indeed the example of L. troile mentioned by Mr. Merrill is the only New England one of which I have any knowledge." (Bull. Nutt. Club, vii, I882, p. 25 I.)

\section{RAZOR-BILLED AUK. \\ UtaMANia TORDA (L.) Leach.}

Chars. Brownish-black, browner on the head and throat; under parts from the throat (in summer; from the bill in winter, and in young), tips of secondaries, and sharp line from bill to eye, white; bill black, with a white, curved line; mouth yellow. Length, 16.00-19.00; wing, 7.00-8.00; tail, 3.00-3.50, graduated 1.00 or more; tarsus 1.00-1.25; bill, 1.33, along gape 2.25 , nearly I.०0 deep.

Chiefly a winter visitant along the coast, to which all the species of this marine family are confined. Long 
Island Sound appears to be about the normal southward limit of distribution of the species, and it is not common there, though doubtless occurring each winter. On the coast of Maine the bird occurs also in summer, being therefore resident in some localities, as the islands in the Bay of Fundy, where it breeds, though in nothing like the numbers found farther north. The single egg is deposited on the bare rock of sea-girt cliffs; it measures about $3.00 \times 2.00$, and is white or whitish, streaked, spotted, and blotched with dark-brown. The egg resembles those Murre's eggrs, the ground color of which is whitish, but is less pointedly pyriform, and the markings are rather in spots than in zigzags.

Respecting the Great Auk, Alca impennis, it is only necessary to refer to the fact that it has for many years been wholly extinct, though formerly abundant at least as far south as Massachusetts, where its bones in kitchenmiddings still attest its presence in years gone by. It is perhaps the only bird of New England which no one could criticize Dr. Brewer for expunging from the list, had he been inclined to follow Nature in so doing. 



\section{INDEX OF ENGLISH NAMES.}

Auk, Great, 40r.

Razor-billed, 400.

Avocet, American, 180.

Baldpate, 309.

Barrow's Golden-eye, 317 ,

Bee-martin, I 5 .

Bittern, American, 269.

Least, 273 .

Black Skimmer, 376.

Bob-white, 157.

Booby, 335 .

Broad-bill, 3 I r.

Brown-back, 198 .

Bull-bat, 52.

Burgomaster, 346 .

Buzzard, Broad-winged, ז25.

Carrion Crow, 137.

Red-shouldered, 123.

Red-tailed, I2I.

Rough-legged, 126.

Swainson's, 124.

Turkey, 135 .

Calico-bird, 178 .

Carrion Crow, 137.

Chicken, Mother Carey's, 38 r.

Coot, American, 294 . Sea, 328 .

Cormorant, Common, 339.

Double-crested, 340 .

Crake, Little Black, 289 . Yellow, 287.

Crane, Brown, 277.

Great White, 276 .

Sand-hill, 277.

Whooping, 276.

Crow, Carrion, I 37 .

Cuckoo, Black-billed, 65 .

Yellow-billed, 67.

Curlew, American Whimbrel, 250.

Dough-bird, 25 I.

Eskimo, 25I.

Hudsonian, 250.

Long-billed, 248.

Sickle-bill, 248.
Dabchick, 393.

Diver, Black-throated, 389 .

Great Northern, 388.

Red-throated, 390.

Dough-bird, 251.

Dowitcher, 198.

Dovekie, 395 .

Dove, Mourning, 140.

Sea, 395 .

Wild, 140.

Duck, American Black Scoter, 326.

Baldpate, 309. Widgeon, 309 .

Barrow's Golden-eye, 317.

Broad-bill, 31 .

Black, 306.

Blue-winged Teal, 3 I r.

Buffle-head, 3 I8.

Canvas-back, 316 .

Dusky, 306.

Eider, 324 .

European Teal, 3 ro.

European Widgeon, 309 .

Fish, 33I.

Gadwall, 308.

Golden-eyed, 317.

Goosander, 33r.

Greater Scaup, 313.

Green-winged Teal, 3 ro.

Harlequin, 323 .

Hooded Merganser, 333 .

King Eider, 326.

Labrador, 320.

Lesser Scaup, 314.

Long-tailed, 319 .

Mallard, 304.

Merganser, 331.

Pied, 320.

Pintail, $30 \%$.

Pochard, 3I 5 .

Red-breasted Merganser, 332.

Red-head, 315.

Ring-neck Scaup, 3I 4.

Rocky Mountain Garrot, 317. 
Duck, Ruddy, 330.

Saint Domingo, 330.

Sea-coot, 328.

Shoveller, 3 II.

Sprigtail, 307.

Surf, 328.

Summer, 312.

Velvet, 327 .

Whistier, 317 .

White-winged Scoter, 327 .

Wood Duck, 312.

Eagle, Bald, 133 .

Golden, 130.

Egret, Great White, 260. Small White, 262.

Falcon, Peregrine, III.

Pigeon, 117 .

Rusty-crowned, 118 .

Flicker, 82 .

Flycatcher, Acadian, 31.

Arkansas, 13.

Bee-martin, 15 .

Gray King-bird, 14.

Great-crested, I8.

Kinglird, 15 .

Least, 41 .

Olive-sided, 26.

Pewee, 23.

Pewit, 23.

Phoebe-bird, 23.

Swallow-tailed, 12.

Traill's, 36 .

Wood Pewee, 28.

Yellow-bellied, 44 .

Fresh-water Marsh Hen, 282.

Frigate-bird, 34I.

Gadwall, 308 .

Gallinule, Florida, 29r. Purple, 292.

Gannet, Booby, 335 .

Brown, 335.

Common, 334 .

Solan Goose, 334.

Garrot, Rocky Mountain, 317 .

Gerfalcon, American Continental, 110. Iceland, 111 .

Labrador, i 10.

Godwit, Great Marbled, 230.

Hudsonian, 232.

Goosander, $33 \mathrm{I}$.

Goose, American White-fronted, 298.

Bamacle, 300.

Brant, 301.

Black Brant, 302.

Blue, 299.

Canada, 303.

Common Wild, 303 .

Lesser Canada, 304.

Snow, 299.
Goose, Solan, 334.

Goshawk, American, 108.

Greater Long-beak, 202.

"Yellow-legs, 236.

Lesser ". 237.

Grebe, American Red-necked, 39r.

Crested, 391.

Dabchick, 393.

Horned, 392.

Pied-billed, 393.

Grouse, Canada, I 48 .

Prairie Hen, 146.

Ruffed, 150.

Spruce Partridge, 148.

Guillemot, Black, 396.

Brinnich's, 398.

Common, 397.

Murre, 397.

Sea Pigeon, 396.

Thick-billed, 398.

Gull, Black-headed, 35 r.

Bonaparte's, 352 .

Burgomaster, 346 .

Common, 348 .

Fork-tailed, 353 .

Glaucous, 346.

Great black-backed, 347 .

Herring, 348 .

Kittiwake, 350.

Laughing, $35 \mathrm{x}$.

Ring-billed, 349 .

White-winged, 346 .

Harrier, 101 .

Hawk, American Goshawk, 108.

Broad-winged Buzzard, 125.

Chicken, 105.

Cooper's, 105.

Duck, i I r.

Fish, 127.

Harrier, 101.

Hen, I $2 \mathrm{I}$.

Marsh, Ior.

Osprey, 127.

Pigeon, 117.

Red-shouldered Buzzard, 123.

Red-tailed "

Rough-legged " 126.

Sharp-shinned, ro4.

Sparrow, 118 .

Swainson's Buzzard, r 24.

Swallow-tailed, 103.

Hen, Fresh-water Marsh, 282.

Prairie, 146.

Salt-water Marsh, 279.

Heron, Great Blue, 259.

Green, 264

Little Blue, 263.

Night, 265 . 
Heron, Qua-bird, 265.

Smail White, 262.

Squawk, 265.

Yellow-crowned Night, 267.

Humming Bird, Ruby-throated, 59

Ibis, Glossy, 254 .

White, 257.

Jaeger, Arctic, 345.

Long-tailed, 345 .

Parasitic, 344.

Pomarine, 344.

Richardson's, 344 .

Skua, 343 .

Jerfalcon, American Continental, ı ı o. Iceland, II I .

Labrador, I I 0 .

King-bird, 15 .

Gray, I 4.

Kingfisher, Belted, 62 .

Kite, Swallow-tailed, I o3.

Knot, 228.

Loon, Black-throated, $38 \mathrm{~g}$. Great Northern, 388. Red-throated, 390.

Mallard, 304.

Man-of-war Bird, $34 \mathbf{I}$.

Merganser, 331.

Fish Duck, 331.

Goosander, 331 .

Hooded, 333.

Red-breasted, 332.

Mother Carey's Chicken, 381.

Murre, 397.

Night-hawk, 52.

Osprey, 127.

Owl, Ácadian, 98 .

Barn, 86.

Barred, 94.

Burrowing, 99.

Day, 96.

Great Gray, 92.

"Horned, 87.

Hawk, 96 .

Long-eared, 9o.

Mottled, Sg.

Red, 89 .

Richardson's, 97.

Saw-whet, 98 .

Screech, 89 .

Short-eared, 9r.

Snowy, 94.

Oyster-catcher, American, I77.

Turnstone, 178 .

Parrot, Sea, 394.

Partridge, 150.

American, 157.

Spruce, I 4 S.

Pelican, American White, 337.

Brown, 338 .
Petrel, Fulmar, 3 So.

Leach's, 382 .

Mother Carey's Chicker, 381 .

Pintado, 386.

Stormy, $38 \mathbf{r}$.

Wilson's, 383 .

Pewee, 23

Wood, 28.

Pewit, 23.

Phalarope, Northern, I 87.

Red, I So.

Wilson's, $1 S_{4}$.

Phoebe-bird, 23.

Pigeon, Passenger, 139.

Wild, I 39.

Plover, Black-bellied, I63.

Golden, I 66.

Killdeer, 168.

Pale Ring-neck, 175.

Piping, 175.

Ring-neck, 173.

Ruddy, 229.

Semipalmated Ring. I73.

Upland, 245.

Wilson's, 170.

Pochard, 3 5 .

Prairie Hen, I46.

Ptarmigan, Willow, 145.

Puffin, Common, 394.

Sea Parrot, 39.4.

Tufted, 395 .

Qua-bird, 26 .

Quail, I 57 .

American Partridge, I 57.

Bob-white, 157 .

Messina, 162.

Migratory, 162.

Rail, Carolina, 286

Clapper, 279.

Fresh-water Marsh Hen, 282 .

King, 282.

Little Black, 289 .

Salt-water Marsh Hen, 279.

Sora, 286.

Virginia, 283 .

Yellow, 287 .

Recve, 243.

Ring-neck, 173 .

Rocky Mountain Garrot, 317.

Ruddy Plover, 229.

Ruff, 243 .

Salt-water Marsh Hen, 279.

Sanderling, 229.

Sandpiper, American Green, 238.

Ash-colored, 228.

Baird's, 2 I 7.

Bartramian, 245.

Bonaparte's, 221.

Buff-breasted, 246. 
Sandpiper, Curlere', 224.

Grass Snipe, 220.

Jack Snipe, 220.

Knot, 228.

Least, 2 I 4 .

Pectoral, 220.

Purple, 222.

Red-backed, 223.

Red-breasted, 228.

Reeve, 243.

Robin Snipe, 228.

Ruddy Plover, 229.

R'uff, 243 .

Sanderling, 229.

Semipalmated, 212.

Solitary, 238.

Spotted, 241.

Stilt, 206.

Upland Plover, 245.

White-rumped, 221.

Scoter, American Black, 326.

White-winged, 327 .

Sea-coot, 328 .

"Dove, 395.

"Parrot, 394.

"Pigeon, 396.

"Swallow, 358 .

Shearwater, Greater, 383 .

Mank's, $3 S_{4}$.

Northern, $38_{4}$.

Sooty, 385 .

Wandering, $38_{3}$.

Shoveller, $31 \mathrm{I}$.

Sickle-bill, 248.

Skimmer, Black, 376.

Snipe, American, 194.

Brown-back, 198.

Dowitcher, 198.

Grass, 220.

Gray, 198 .

Greater long-beak, 202.

Jack, 220.

Red-breasted, 198.

Robin, 228.

Stone, 236.

Wilson's, 194.

Solan Goose, 334.

Sora, 286.

Squawk, 265.

Stilt, Black-necked, I 82.

Stone Snipe, 236.

Swallow, Sea, 358 .

Swan, American Wild, 296.

Trumpeter, 296.

Swift, Chimney, 56.
Tattler, Greater, 236.

Lesser, 237.

$$
\text { "Yellow-legs, } 236 .
$$

“ Yellow-legs, 237.

Semipalmated, 233.

Solitary, 238.

Spotted Sandpiper, 241.

Stone Snipe, 236.

Willet, 233.

Teal, Blue-winged, $3 \mathbf{r}$.

European, 310.

Green-winged, 310.

Tern, Arctic, 370.

Black, 375 .

“ Skimmer, 376.

Caspian, 355 .

Cayenne, 357.

Common, 358.

Forster's, 369.

Gull-billed, 355 .

Least, $37 \mathrm{I}$.

Marsh, 355 .

Roseate, 371.

Royal, 357 .

Sandwich, 357.

Sea Swallow, 358 .

Short-tailed, 375 .

Sooty, 372.

Wilson's, 358 .

Tropic-bird, $34^{2}$.

Turkey, Wild, 143 .

Turnstore, 178 .

Upland Plover, 245.

Whimbrel, American, 250.

Whippoorwill, 50.

Whistler, 317.

Widgeon, American, 309.

European, 309.

Willet, 233.

Woodcock, $19 \mathbf{I}$.

European, 194

Woodpecker, Black-backed, three-toed, 74.

Downy, 72.

Flicker, 82 .

Golden-winged, 82.

Hairy, $7 \mathbf{1}$.

Pileated, 69.

Red-bellied, 79 .

Red-headed, 80.

White-backed, three-toed, 76 .

Yellow-bellied, 76 .

Wood Pewee, 28.

Yellow-legs, Greater, 236.

Lesser, 237. 


\section{INDEX OF SCIENTIFIC NAMES.}

Accipiter cooperi, 105. fuscus, 104.

Actodromas bairdi, 217. bonapartii, 221 . maculata, 220. minutilla, 214.

Egialites melodus, 175 . semipalmatus, 173 . vociferus, 168 . wilsonius, 170.

Aix sponsa, 3 I 2.

Alca impennis, 401 .

Alle nigricans, 395 .

Aluco flammeus pratincola, 86 .

Anas boscas, 304 . obscura, 306.

Ancylochulus subarquatus, 224.

Anser albifrons gambeli, 298.

Antrostomus vociferus, 50 .

Aquila chrysaetus, 130 .

Archibuteo lagopus sancti-johannis, 126.

Ardea herodias, 259.

Ardetta exilis, 273.

Arquatella maritima, 222.

Asio accipitrinus, 9r. wilsonianus, 90 .

Astur atricapillus, jo8.

Bartramia longicauda, 245.

Bernicla brenta, $30 \mathrm{r}$.

brenta nigricans, 302 .

canadensis, 303 .

canadensis hutchinsi, 304 .

leucopsis, 300 .

Bonasa umbella, 150.

Botaurus mugitans, 269.

Bubo virginianus, 87 .

Buteo borealis, I2I.

lineatus, 123 .

pennsylvanicus, 125 .

swainsoni, 124.

Butorides virescens, 264.

Calidris arenaria, 229.

Camptolæmus labradorius, 320.

Canace canadensis, 148 .
Catharista atrata, 137 .

Cathartes aura, 135 .

Centurus carolinus, 79 .

Ceryle alcyon, 62.

Chætura pelasgica, 56 .

Charadrius dominicus, $\mathbf{6} 66$.

Chaulelasmus streperus, 308 .

Chen cœrulescens, 299.

hyperboreus, 299.

Chordediles popetue, 52 .

Chroïcocephalus atricilla, $35 \mathrm{I}$. philadelphia, 352 .

Circus cyaneus hudsonius, 10 r.

Clangula albeola, 318. glatcium, 317 . islandica, 317.

Coccygus americanus, 67. erythrophthalmus, 65 .

Colaptes auratus, 82 .

Colymbus arcticus, 389 . septentrionalis, 390. torquatus, 388 .

Contopus borealis, 26. virens, 28 .

Coturnix dactylisonans, $\mathbf{1 6 2 .}$

Cupidonia cupido, 146.

Cygnus columbiantis, 296. buccinator, 296.

Cymochorea leucorrhoa, ${ }_{3} 82$.

Dafila acuta, 307 .

Daptium capense, 386 .

Ectopistes migratorius, 139 .

Elanoïdes forficatus, 103 .

Empidonax acadicus, $3 \mathbf{1}$. flaviventris, 44 . minimus, $4 \mathrm{I}$.

trailli, 36 .

Ereunetes pusillus, $2 \mathbf{2} 2$.

Erismatura rubida, 330.

Eudocimus albus, 257.

Falco gyrfalco, 109 .

" islandicus, IIr.

" obsoletus, 1 ro.

" sacer, I 10. 
Falco columbarius, 117 . peregrinus, 111 . sparverius, 118.

Florida coerulea, 263.

Fratercula arctica, 394. cirrata, 395.

Fulica americana, 294 .

Fuligula affinis, 314 . collaris, 314 .

ferina americana, 315 . marila, 313 . vallisneria, 316.

Fulmarus glacialis, 380 .

Gallinago wilsoni, 194 .

Gallinula galeata, 291 .

Garzetta candidissima, 262.

Grus americana, 276. pratensis, 277 .

Hæmatopus palliatus, 177 .

Haliaëtus leucocephalus, 133 .

Harelda glacialis, 319.

Herodias egretta, 260.

Himantopus mexicanus, i 82 .

Histrionicus minutus, 323 .

Hydrochelidon lariformis, 375 .

Hylotomus pileatus, 69 .

Ionornis martinica, 292.

Lagopus albus, 145 .

Larus argentatus smithsonianus, 348 . delawarensis, 349 .

glaucus, 346 .

leucoptei us, 346 .

marinus, 347 .

Limosa fœda, 230 . hæmastica, 232.

Lobipes hyperboreus, 187 .

Lomvia arra, 398. troile, 397.

Machetes pugnax, 243.

Macrorhamphus griseus, I98.

Mareca americana, 309. scolopaceus, 202. penelope, 300 .

Melanerpes erythrocephalus, 80 .

Meleagris gallipavo americana, 143 .

Mergus cuculatus, 333 . merganser, 331 . serrator, 332 .

Micropalama himantopus, 206.

Milvulus forficatus, 12 .

Myiarchus crinitus, 18 .

Nomonyx dominica, 330.

Numenius borealis, 251 .

hudsonicus, 250. longirostris, 248 .

Nyctala acadica, 98 . tengmalmi richardsoni, 97 .

Nyctea scandiaca, 94 .

Nycterodius violaceus, 267.
Nyctiardea grisea nævia, 265.

Oceanites oceanicus, 383 .

CEdemia americana, 326 . fusca, 327 . perspicillata, 328 .

Ortyx virginiana, 157

Pandion haliaëtus, 127 .

Pelecanus fuscus, 338 . trachyrhynchus, 337 .

Pelidna alpina americana, 223.

Phalacrocorax carbo, 339 . dilophus, 340 .

Phalaropus fulicarius, 189 .

Philohela minor, I9I.

Picoïdes americanus, 76 . arcticus, 74 .

Picus pubescens, 72 . villosus, $7 \mathbf{l}$.

Plegadis falcinellus, 254.

Podicipes cornutus, 392. cistatus, 39I. griseigena holbœlli, 391.

Podilymbus podicipes, 393 .

Porzana carolina, 286. jamaicensis, 289 . noveboracensis, 287 .

Procellaria pelagica, $38 \mathbf{1}$.

Puffinus anglortm, 384 . borealis, ${ }_{3} \delta_{4}$.

fuliginosus, $3 S_{5}$.

major, $3 \delta_{3}$.

Querquedula carolinensis, 3 Io.

crecca, 310.

discors, 311 .

Rallus elegans, $2 \delta_{2}$. Iongirostris crepitans, 279.

Rallus virginianus, 283 .

Recurvirostra americana, 1 \&o.

Rhyacophilus solitarius, 238 .

Rhynchops nigra, 376.

Rissa tridactyla, 350 .

Sayiornis fusca, 23 .

Scolopax rusticula, 194 .

Scops asio, 89 .

Somateria mollissima dresseri, $3^{24}$. spectabilis, 326 .

Spatula clypeata, 3II.

Speoty to cunicularia hypogæa, 99.

Sphyropicus varius, 76 .

Squatarola helvetica, 163 .

Steganopus wilsoni, 184 .

Stercorarius buffoni, 345 . parasiticus, 344. pomatorhinus, 344 skua, 343 .

Sterna anglica, 355 . cantiaca, 357 . caspia, 355 . dougalli, 37 I. 
Sterna forsteri, 369 .

fuliginosa, 372 .

hirundo, $35^{8}$.

macrura, 370 .

maxima, 357 .

supercilliaris antillarum, 371 .

Strepsilas interpres, I 78 .

Strix cinerea, 92. nebulosa, 94 .

Sula bassana, 334 . leucogastra, 335 .

Surnia funerea, 96 .

Symphemia semipalmata, 233 .

Tachypetes aquilus, $34 \mathrm{I}$.
Totanus flavipes, 237.

melanoleucus, 236 .

Tringa canutus, 228 .

Tringoïdes macularius, $24 \mathrm{r}$.

Trochilus colubris, 59 .

Tryngites rufescens, 246 .

Tyrannus carolinensis, 15 .

dominicensis, $\mathbf{1} 4$. verticalis, 13 .

Uria grylle, 396 .

Utamania torda, 400.

Xema sabinii, 353 .

Zenaidura carolinensis, $\mathbf{1} 40$. 



\title{
New England Bird Life: \\ BEING
}

\author{
A MANUAL OF NEW ENGLAND \\ ORNITHOLOGY.
}

\author{
Revised and edited from the manuscript of WINFRID A. STEARNS, \\ Member of the Nuttall Ornithological Club, etc. \\ By Dr. Elliott COUES, U.S.A., \\ Member of the Academy, etc.
}

Part 1. Oscines (Singing Birds). Illustrated, \$2.50.

The most complete Cyclopedia of Singing-Birds of New England. The Editor's name is a guarantee that the work is thoroughly and completely prepared.

"The study of the ornithology of New England has been carried forward with rapid strides during the last few years, and the time has arrived when a standard volume, covering the whole ground, and presenting in a concise and convenient form an epitome of bird life of New England, should be written. Such a work Mr. Winfrid A. Stearns undertook several years ago at the suggestion of Dr. Coues. The plan of this book is to give descriptions of the birds themselves, enabling the student to identify any specimen he may have on hand; local distribution, migration, and relative abundance of every specie.

"The manuscript has been revised and edited by Dr. Elliott Coues, and the present volume, embracing the large and important order Oscines, has received in its arrangement and in its copious illustration the personal supervision of that gentleman. The work is an invaluable one for the student, containing, as it does, the results of the latest investigations and being especially aclapted to practical use." - Boston Courier.

"It is a valuable addition to the literature of Ornithology, and its value and interest are increased by the very meritorious illustrations. It is doubtless the most complete and satisfactory exposition of the bird life of New England that has yet appeared." - Salem Gazette.

"This book is a benefaction to the rising generation which they cannot too highly prize. Let it find a place on every parlor table and in every public library." -Portland Argus.

"The volume is in its way a model of thoroughness." - Milwaukee Sentinel.

"It is exhaustive and reliable, giving almost everything in relation to the feathered songsters, and containing everything that the casual reader will care to know, while the naturalist cannot fail to be delighted with it." - Philadelphic Chron-Herald.

"For the romance and poetry of the subject one will of course have to look elsewhere. Our feathered songsters are here seen, as it were, lifeless and cold upon the dissecting table; instead of forms instinct with life, brilliant with fluttering plumage, and vocal with melodious songs, we are shown through shallow drawers full of the stuffed skins of birds only, which we may handle with the cool criticism of the true scientist." - The Literary World. 
"To say that the book is exceedingly well written would be doing it scant justice. Dr. Coues' brilliant talents in this respect are already well known, but we have, perhaps, never had so striking a proof of them as is afforcled by the present volume. The work has been done so thoroughly that in point of completeness it is almost perfect; so consistently, that but few points are open to criticism; so concisely, that one hundred and thirty-eight species are treated in two hundred and seventy octavo pages, and the arrangement of the whole is masterly. Gracefully turned descriptive passages and sparkling bits of commentary everywhere enliven the subject, as the brighter colors of an old piece of tapestry set off its more sombre background." - Bulletin of the Nuttall Ornithological Club."

"Those who are familiar with the Editor's felicitous style, as displayed, especially in his 'Birds of the Northwest' and 'Birds of the Colorado Valley,' will not fail to recognize his touches on nearly every page, or his influence on the general execution of the work." - N. Y. Nation.

"Mr Stearns began the book several years ago. He performed his task with great care and labor. After finishing his part of the work he handed the MSS. over to Dr. Elliott Coues, the distinguished ornithologist, to be edited. This gentleman has done more than any other man in the country to popularize the study of American birds. He revised the book, rewriting considerable of it. Those accustomed to the lively, graceful style of his other books will frequently recognize his touch in these pages. So now we may be considered to havea perfect book about the birds of New England, at least until some disagreeable scientific man finds out something more." - Cincinnati Commercial.

"It is the most complete and thorough study in its particular branch that has yet appeared. In the present work, thoroughness seems to be the prime idea, and everything that exists in New England bird life is carefully classified and described. The publishers, with characteristic zeal, have ably seconded the efforts of author and editor, and the work is presented in a neat and attractive style." Boston Times.

"Will undoubtedly take a conspicuous place among the works descriptive of the feathered inhabitants of our section." - Boston Commonzvenlth.

"Will no doubt be received by the public with special favor, and be regarded by educators as a standard authority." - Chicago Journal.

"It is the object of the present volume to go carefully over the whole ground, and present, in concise and convenient form, an epitome of the bird life of New England." - Albany Journal.

"Its method and scope are all that could be desired in a general scientific treatise, and it fills a place hitherto unoccupied." - Boston Trazeller.

"The work seems to have been done with thoroughness and knowledge, and commends itself strongly to ornithologists on that account. It is fully illustrated." - Boston Transcript.

"It is handsomely printed, well illustrated, and will be found a complete and thoroughly serviceable manual of reference by all students." - Cincinnati Gazette.

"It is prepared by acknowledged authority, and is practical and popular rather than exhaustive. It is just the book to take down from one's library-shelf in answer to the question 'What bird is that?' It is just the book to give a twelveyear old boy when he begins to be curious about birds. It is just the book to go into a school reference library." - N. Y. Christian Union.

"The work is thorough and up to date, and such a book ought to be put in the hands of ten thousand boys that have a gun. It will do for the Northern Middle States." - N. Y. Independent.

\section{Sold by all Booksellers and Newsdealers, and sent by mail, postpaid, on receipt of price.}

\section{LEE AND SHEPARD, PUBLISHERS, BOSTON.}







